\title{
EXPLORING THE LYRIC-DRAMATIC INTERACTION IN THE WORK OF T.S. ELIOT
}

by

Patrick Prashant Coelho

A thesis submitted to the Victoria University of Wellington in fulfilment of the requirements for the degree of Doctor of Philosophy in English and Theatre

Victoria University of Wellington

2010 


\begin{abstract}
T. S. Eliot's fascination with the interaction between the lyric and the dramatic is evident from the fact that his poetry was often dramatic even before he began to write verse drama. Part of the reason for this interaction in Eliot was a kind of radical modernism that ensured a return to a primitivism where there was little distinction between the lyric and the dramatic. In this thesis I argue that this interaction is central to the nature of Eliot's creative work. The need for an interaction between the lyric and dramatic meant that The Waste Land (1922) possessed several dramatic qualities making it a precursor to Eliot's entry into the realm of poetic drama with the play, Sweeney Agonistes (1932). As part of my thesis, I conducted theatre workshops of the first two parts of The Waste Land in order to discover what dramatic elements emerged from the text and how their presence affected the lyricdramatic interaction in the work, something which can surface only through performance. I argue that The Waste Land and Sweeney Agonistes occupy critical spaces in the mapping of the lyric-dramatic interaction in Eliot's creative oeuvre. The intensity of the lyric-dramatic interaction in Eliot's poetry builds up to a moment where he comes extremely close to drama in The Waste Land moving him to ultimately write his first play, Sweeney Agonistes. While Eliot's works after these two texts continue to exhibit characteristics of this lyric-dramatic interaction, the nature of this interaction undergoes a transformation after Eliot's conversion, manifesting itself in his religious poetry and drama which turns out to be a cul-de-sac in his experimentations. The intensity of this interaction in his work then gradually reduces to a point where the lyric and the dramatic no longer overlap especially after Eliot's first commercially successful play, The Cocktail Party (1949). By examining the reasons for the slow disassociation of these two crucial elements in Eliot's later work, I aim to stress the centrality of The Waste Land and Sweeney Agonistes to the lyric-dramatic trajectory in his work.
\end{abstract}




\section{Acknowledgements}

I owe a deep debt of gratitude to my supervisors Dr. Charles Ferrall and Dr. Matt Wagner whose insightful and inspiring words of advice never failed to spur me on. I would also like to thank all staff, both teaching and non-teaching, at Victoria University's School of English, Film, Theatre and Media Studies, and all librarians. I wish also to thank Victoria University of Wellington for awarding me with the Victoria University $\mathrm{PhD}$ and $\mathrm{PhD}$ Completion Scholarships which have enabled me to complete this work.

A heart-felt thank you goes out to all the cast and crew of The Waste Land for their hard work and dedication to the project. The work was all yours. My cast and crew included: Hannah McKie, Fiona Shaw, Yu Ting, Nicola Clements, Kristina Bunting, Dan Watterson, Tom Horder, William Mcelwee, Ralph Upton, Jacob Ennis, Paul Reddish and Gregor Cameron. Special thanks go out to Gregor, my dramaturge, who also video-recorded the performances, edited these recordings and was an invaluable font of knowledge throughout the process, and to Hannah who also designed the posters, flyers and the audience handouts for the production. Here, I need to thank Dr. Wagner once again for his wonderful supervision of the production and amazing insight into the theatre, and to Dr. Ferrall for all his advice and support before, during and after the production. Special thanks are due to theatre staff James Davenport, Horst Sarubin and Jo Bean for their help during the production. Thanks also go out to Matthias Paetzel and Sugu Pillay for their assistance during the production and to Brian McKeon for his advice on copyright laws. Thanks also to my officemate, Tim Jones, for his patient and in-depth responses to my questions over the past three years!

I must acknowledge, here, my gratitude to my parents and sister, Conrad, June and Sarita, for providing me with a comforting and exciting world of literature, music and theatre in which to grow up. Among friends in India, I owe thanks to Dr. T. R. Joy, presently at Loyola College, Chennai, whose questioning gave me the answers to some of the problems related to my thesis proposal early on.

I think I have covered all of the people I need to thank here and if I have missed out on anyone I beg forgiveness. But, before I end, I must thank my lovely wife Đoan Hạ for providing me with her critical feedback and for supporting me always. 


\section{TABLE OF CONTENTS}

\section{INTRODUCTION: UNRAVELLING THE THREAD OF THE}

0.1 The need to study the lyric-dramatic interaction in Eliot's work 8

0.2 Defining the lyric and the dramatic 9

0.3 The changing nature of the interrelationship between the lyric and dramatic 12

$\begin{array}{lr}0.4 \text { Conclusion } & 13\end{array}$

CHAPTER ONE: ELIOT'S THEORY OF DRAMA - BUILDING A

BRIDGE BETWEEN THE LYRIC AND THE DRAMATIC 14

1.1 Introduction: 'Primitivism' in Eliot's time 14

1.2 A taste for the 'primitive' in adolescence and an early interest in drama 16

$\begin{array}{ll}\text { 1.3 The Cambridge Ritualists } & 20\end{array}$

1.4 Eliot's anti-realism in the drama 22

1.5 Alternatives to realism in the theatre 23

$\begin{array}{ll}\text { Symbolists, puppets and masks } & 23\end{array}$

The music-hall, the Chorus and cinema 26

Dance and rhythm 29

The Mass as ritual, dance and drama 32

1.6 Language and form for a modern verse drama 33

$\begin{array}{ll}1.7 \text { Conclusion } & 34\end{array}$ 
2.1 Introduction 36

2.2 The dandy and ironic splitting 38

2.3 Use of the dramatic monologue 49

$\begin{array}{ll}2.4 \text { Spotlight on the stage: Vaudeville and marionettes } & 60\end{array}$

$\begin{array}{ll}2.5 \text { The dramatic in the Sweeney poems } & 68\end{array}$

$\begin{array}{ll}2.6 \text { Conclusion } & 72\end{array}$

CHAPTER THREE: FROM POETRY TO PERFORMANCE: THE LYRIC-DRAMATIC INTERFACE IN THE WASTE LAND 73

3.1 Critics on the dramatic in The Waste Land; the workshop production 73

$\begin{array}{ll}\text { 3.2 Dramatic elements in the production } & 77\end{array}$

$\begin{array}{ll}\text { Voices, dialogue and audience } & 77\end{array}$

$\begin{array}{lr}\text { Rhythm, movement and ritual } & 87\end{array}$

Tension and conflict $\quad 91$

$\begin{array}{ll}\text { Chorus and music-hall } & 93\end{array}$

$\begin{array}{ll}3.3 \text { Conclusion } & 97\end{array}$

CHAPTER FOUR: WANNA GO HOME, BABY? THE LYRIC IN

\begin{tabular}{lr} 
SWEENEY AGONISTES & 98 \\
\hline
\end{tabular}

$\begin{array}{ll}\text { 4.1 Introduction } & 98\end{array}$

4.2 Lyric elements in the play $\quad 99$

The rhythm of jazz 99

$\begin{array}{ll}\text { Backchat and Minstrelsy } & 108\end{array}$ 
"Do you want to flirt with me?" Songs in the play

Melodrama: Bringing together music and drama

\section{CHAPTER FIVE: THE LYRIC-DRAMATIC DYNAMIC AFTER}

$\begin{array}{ll}\text { 5.1 Introduction } & 126\end{array}$

$\begin{array}{lr}\text { 5.2 The Rock } & 129\end{array}$

$\begin{array}{ll}\text { As pageant play } & 129\end{array}$

$\begin{array}{ll}\text { The Chorus, ritual and music } & 131\end{array}$

5.3 Murder in the Cathedral: Christian ritual and Greek Choral traditions $\quad 138$

5.4 A return to secular drama: The Family Reunion 145

$\begin{array}{ll}\text { The shift from religious drama } & 145\end{array}$

"Why do we feel embarrassed?" The Chorus in The Family Reunion 146

$\begin{array}{ll}\text { Lyrical duets } & 149\end{array}$

5.5 The Cocktail Party and after 153

5.6 The dramatic in the poems after The Waste Land 158

5.7 Voices in ‘The Hollow Men’ (1925) 159

5.8 The Ariel poems: 'Journey of the Magi' and 'A Song for Simeon' 162

5.9 Christian ritual, hymns and the Mass in Ash-Wednesday 165

$\begin{array}{ll}\text { 5.10 Old Possum's Book of Practical Cats } & 169\end{array}$

$\begin{array}{ll}5.11 \text { Four Quartets } & 171\end{array}$

$\begin{array}{ll}5.12 \text { Conclusion } & 174\end{array}$

CONCLUSION: TYING UP THE THREADS OF THE LYRICDRAMATIC INTERACTION IN ELIOT 
INSIDE BACK COVER JACKET: COPY OF DVD OF THE WORKSHOP PRODUCTION OF THE WASTE LAND PERFORMED IN SEPTEMBER 2008 AT VICTORIA UNIVERSITY OF WELLINGTON 


\section{LIST OF FIGURES}

Figure 1: Marie in the cafe with a male companion and on the box ........................80

Figure 2: Rising in rhythm to the opening lines of 'The Burial of the Dead' .............89

Figure 3: A crowd flowed over London Bridge, so many (Complete 62, 1. 62) ........90 


\section{Introduction: Unravelling the Thread of the Lyric- Dramatic Interaction in Eliot}

\subsection{The need to study the lyric-dramatic interaction in Eliot's work}

Several Modernist writers believed that humankind had suffered from some kind of calamitous "Fall" at a particular time in history, one that led to a culturetransforming fragmentation. For Hulme, this fragmentation occurred during the Renaissance and led to the birth of Romanticism (50). For Lawrence it was sickness, specifically syphilis, which had caused a "grand rapture" around the late sixteenth century in Elizabethan England with the "mental consciousness recoiling in violence away from the physical, instinctive-intuitive." This recoiling led, in turn, to an inhibition of the intuitive in English art according to Lawrence (307-309). Also, Yeats believed that some kind of perfection had been achieved during the Byzantine period implying that there had been a "Fall" of some kind in subsequent art and literature.

Similarly, T.S. Eliot expressed a belief in a "dissociation of sensibility" that had set into poetry in the seventeenth century and which, he believed, was a result of a split between thought and feeling after the Metaphysical poets (Selected 288). I will argue that a belief in the divide between the lyric and dramatic, something that Eliot observed and commented on in his early critical essays, was one aspect of this trend towards dissociation. Armed with his readings in primitivism and anthropology he attempted to bridge the gap between the lyric and dramatic by bringing ritual elements back to the drama. In 1923 Eliot observed, "All art emulates the condition of ritual. That is what it comes from and to that it must always return for nourishment” ('Marianne Moore' 597).

In its ritualistic origins drama included several lyrical elements. This ensured that when Eliot attempted to return drama to a state of ritual he was essentially aiming to intensify the lyrical elements in his drama. Simultaneously, the presence of the dramatic in his early poetry was conspicuous by 1909, and it became evident in his monologues before reaching a climax in The Waste Land (1922). With so much of the dramatic in his poetry Eliot inevitably shifted to writing drama in Sweeney Agonistes (1932). By including several lyric elements in his plays he continued to 
present the interaction between the lyric and dramatic albeit in a different way from its occurrence in his poetry.

Several critics have touched upon the dramatic aspects of Eliot's poetry and the lyric aspects of his drama but, as yet, there has been no full-length examination of the crucial interaction between these two elements in his work. The movement towards drama is a vital part of the reason why Eliot's poetry is so radically different from other writers of his day and is a result of the lyric-dramatic interaction in his creative writing. In my thesis, I will illustrate how this interaction is central to the nature of Eliot's creative work between 1909 and 1939. I believe that such a reading helps us discern a common thread running through several of his texts, thus allowing us to analyse the bulk of his career from this perspective. By examining Eliot's work through the lens of the lyric-dramatic interaction we will take a fresh and more compelling look at his drama in such a way that we may no longer see his plays as secondary to the poetry. Instead, we can acknowledge that a dramatic sensibility is a significant part of Eliot's overall creative gesture.

As part of my research, I conducted dramatic workshops of parts one and two of The Waste Land so as to better understand the nature of the lyric-dramatic interaction in the poem. A performance of these parts, the product of the workshops, was staged in September 2008 at Victoria University of Wellington. The workshops were meant to demonstrate the nature of the dramatic elements in these parts and to show how they emerged from the poem itself. The presence of the lyric-dramatic interrelationship in Eliot's work is the main reason why The Waste Land possesses several dramatic qualities and enables him to later cross over from dramatic poetry to poetic drama.

\subsection{Defining the lyric and the dramatic}

To begin, I need to clarify what is meant by the terms 'lyric' and 'dramatic' for the purpose of this thesis. In its earliest avatar the lyric was meant to be sung or chanted to the accompaniment of the lyre in ancient Greece (New Princeton 1165; Abrams, Glossary 109). In fact, Friedrich Nietzsche asserted that lyric poetry was originally song (33). Medieval England, too, had its troubadours and courtly poets who composed verses meant to be sung. However, with the onset of the Renaissance and 
the advent of the printing press in Europe, sixteenth-century English poets no longer focused on lyric poems meant solely for musical presentation before an audience. Instead, they began to concentrate their energies increasingly on writing for a print version aimed at a definite readership (New Princeton 714). With the need for individuality expressed by the Romantic poets of late eighteenth and early nineteenth century Europe, the lyric became a short poem in the written mode directly expressing the poet's thoughts and feelings and the connection to live musical performance was almost completely lost. The form began to assume more insular and non-performance based connotations so that it has now become almost synonymous with the term 'poetry' itself. The word 'lyric' today may be used to describe a kind of poetry which employs "a first-person speaker" who is pre-occupied "with the expression of individual feeling or emotion", a description which is linked to the Romantic understanding of the term (Lindley 2).

Eliot accepts the lyric as his first voice of poetry, a voice where the poet is speaking to himself or to no one at all (On Poetry 97). The lyric poem does not involve the poet or any actor playing the role of some imagined character for an audience (Wolf 24). However, this does not mean that lyrical elements are not present in drama: we can have moments of extreme lyricism in drama. The lyrical in drama not only refers to the individual voice expressing itself, for example in a lyric soliloquy, but could also point to musical moments or sections of intense poetry in drama which may involve one or more actors or a Chorus as we shall see through an examination of Eliot's plays in chapters four and five.

As compared to the lyric, drama has obviously retained its performance aspects as an essential part of its being. When we use the term 'dramatic' in the context of the theatre we imply some action or movement in that space. This movement need not necessarily be accompanied by words but it is generally the case that some speech occurs in drama (Hodgson 103). Thus drama involves the use of dialogue and action which is generally meant to enact a prose or verse story on a stage (OED online). It is a communal act that subsumes the individual for the greater cause of the group. In this sense the drama is less personal than the lyric as it is always performed for an audience.

We get one definition of drama from Beckerman who suggests, "Drama occurs when one or more human beings isolated in time and space present 
themselves in imagined acts to another or others" (20). ${ }^{1}$ Thus, the presence or assumption of the presence of an audience that characters perform for and/or address or interact with is an essential dramatic element. Beckerman's definition sounds close to Eliot's description of drama: "Dramatic verse alone has as its function the making an immediate, collective impression upon a large number of people gathered together to look at an imaginary episode acted upon a stage" (On Poetry 17).

The dramatic also involves characters other than the poet playing assumed roles or parts for the audience, something visible in Eliot's poetry both before and in The Waste Land. In his discussion of the "third voice" of poetry Eliot describes the dramatic process as involving, "the voice of the poet when he attempts to create a dramatic character speaking in verse; when he is saying, not what he would say in his own person, but only what he can say within the limits of one imaginary character addressing another imaginary character" (On Poetry 89).

The elements mentioned above all emerged during the discussions that were part of our workshop production of The Waste Land. In addition to these descriptions of drama, I will use certain other dramatic elements that emerged during the workshops to identify the presence of the dramatic in Eliot's poems. During the workshops the actors mentioned several elements which they felt were essential for working with the poem in a theatrical space. These included the use of voice or voices, time, rhythm, tension or conflict, choral elements, music and dialogue. The dramatic elements in this list are not intended to be exhaustive, they do not necessarily include all the features that make for drama and not all of them are essential. We can do without some of them and still have drama. Nor are they intended to be part of a definition of drama as that is not within the purpose or scope of my study.

Additionally, references will be made to the use of theatrical forms in the poems of Eliot. These include the presence of elements from British music hall or American vaudeville (more specifically from minstrelsy) and from opera. These

\footnotetext{
${ }^{1}$ There are not many definitions of drama over the ages despite a lot of theorizing about the subject. Aristotle, in the Poetics, provided us with what he considered to be the six parts of tragedy - plot, character, diction, thought, spectacle and song (Butcher 25). However, even this is not a definition of drama per se but a description of the kind of play that Aristotle watched during his time. While Aristotle's mention of character is used in this thesis as a dramatic element most of the other elements he mentions are not directly relevant to my thesis and I do not consider them to be essential elements of drama. I am not here concerned with a definition of drama per se but with a presentation of elements that might make up the dramatic to ensure a framework for my study.
} 
obvious theatrical formats present in the poems will help us point to the dramatic in them. ${ }^{2}$ I will deal with these elements in detail in chapter three when I discuss the workshop production of The Waste Land.

\subsection{The changing nature of the interrelationship between the lyric and dramatic}

Aristotle's belief that tragedy had started with "the authors of the Dithyramb" points to the connection of the lyric to drama right from the origins of European drama (19). The Cambridge Ritualists, who strongly influenced Eliot, believed that the dithyramb was a paean or song of praise performed and danced in honour of Dionysus (Harrison, Themis 32). Before them, Nietzsche had already claimed that when "unfolded to their fullest extent" lyric poems were "called tragedies and dramatic dithyrambs" (30). The dithyramb, essentially a ritual, was both lyrical, because it was a song, and dramatic, due to its dance movements. The ancient Greek drama, which arose from the dithyramb, was therefore also highly lyrical.

In England and mainland Europe, Medieval plays produced or sanctioned by the Church contained lyrical elements thanks to their ritualistic pattern which allowed the presence of Church music. The lyrical in drama reached new heights in the plays of Elizabethan and Jacobean England, especially in the works of Marlowe and Shakespeare. Thereafter, there was a gradual decline in the lyrical nature of drama so that, by the time Eliot arrived on the scene, realism dominated the theatre and the lyrical element and ritual aspects of drama were almost entirely lost.

Eliot's unhappiness with the rise of realism, as represented by the work of Ibsen and his followers especially Shaw in England, together with his need to bridge the divide between the lyric and dramatic, led him to seek a re-introduction of lyrical elements in drama. As early as 1920 Eliot claimed that "a large number of poets hanker for the stage; and [...] a not negligible public appears to want verse plays. Surely there is some legitimate craving, not restricted to a few persons, which only the verse play can satisfy" (Sacred 60). Eliot was not alone in his desire for a new poetic drama. Others such as the Symbolist playwrights in France and Yeats had already sought a return to such a form. Besides this, expressionist playwrights such

\footnotetext{
${ }^{2}$ For a description of music hall see $73 \mathrm{n} 1$ and for minstrel shows in vaudeville see 109-111 in this thesis.
} 
as Georg Kaiser and Ernst Toller in Germany had already indulged in lyrical monologues in their highly existentialist plays.

Eliot's longing for a new poetic drama had its roots in his quest for a novel style in poetry itself. Stead observes that "the year 1909 marks perhaps the lowest point of a long decline in the quality of English poetry" and believes Eliot's early poetry was part of a new beginning in the genre (41). Eliot's reaction against contemporary verse which comprised, by and large, poor imitations of the earlier Romantic poetry was thus partly behind the introduction of the dramatic in his poetry around 1909. However, his yearning for poetry in drama reveals in him a more fundamental sensibility: that drama and lyricism are, at heart, inseparable each dependent upon the other for its vitality. This sensibility, in turn, leads to his use of dramatic elements in his poetry as well.

\subsection{Conclusion}

In this thesis I will trace the changing nature of the interrelationship between the lyric and dramatic in Eliot's work. I believe that The Waste Land and Sweeney Agonistes are at the core of this relationship and that all the dramatic elements in Eliot's early poetry lead up to the crossover moment when he switches to lyric drama sometime after The Waste Land. Following this moment the lyric and dramatic continue to combine in Eliot's work in different ways. However, there is a gradual decline in the intensity of the interrelation between the lyric and dramatic in his work leading to its ultimate dissolution around 1950. I shall begin my study by exploring Eliot's early interest in primitivism and anthropology and by examining his theories of poetic drama as expressed in his early criticism. 


\section{Chapter One: Eliot's Theory of Drama - Building a Bridge Between the Lyric and the Dramatic}

\subsection{Introduction: 'Primitivism' in Eliot's time}

Eliot's desire for ritual in drama ultimately arose from his interest in primitivism, a topic of considerable currency in the late nineteenth century, partly because of increased contact with and awareness of non-European cultures, a result of years of colonialism, and increased research in the field of anthropology (Rhodes 7). There has always been some notion of what the 'primitive' is, but a stronger, more modern idea of primitivism only really developed in the late nineteenth century, perhaps as a reaction against industrialisation. While the Romantics of late eighteenth-century Europe sought a return to a kind of medievalism, many Modernist artists wanted to go back towards a 'primitive' time in their work.

Catherine Bell describes primitivism as "the nostalgia of civilized man for a return to a 'primitive' or pre-civilized condition" (1). For late nineteenth century artists and writers, primitivism involved not just a return to an original, pre-civilized condition but also a movement towards incorporating or improvising on the art of exotic cultures, cultures that were, as yet, largely foreign to European knowledge. By the early twentieth century, several artists, musicians and writers were dabbling in primitivism of one kind or the other. These included Paul Gauguin, whose primitivism stemmed from his days as a painter in Tahiti in the 1890's, Rudyard Kipling whose novels, Jungle Book (1894) and Kim (1901), Eliot would have been familiar with as a boy and composer Igor Stravinsky whose 'primitive' ballet, $L e$ Sacre du Printemps (The Rite of Spring, 1913), Eliot referred to in his critical writings on drama. Pablo Picasso, the quintessential avant-garde artist, also painted in a style heavily influenced by African sculpture between 1907 and 1909, and influenced the Cubist movement in painting. One of his most famous works Les Desmoiselles d'Avignon (1907) was directly impacted by exhibits of African art at 
The Musée d'Ethnographie du Trocadéro in Paris. ${ }^{1}$ In literature, Joseph Conrad stoked the fires of western curiosity for life in the interiors of Africa with his novella The Heart of Darkness (1902) to such an extent that Eliot considered using a line from it as the original epigraph to The Waste Land (Waste Land Facsimile 3).

Eliot was influenced by his fellow Modernist writers who employed ideas from contemporary anthropological writings to redefine their literary world. The interest of Modernist artists in anthropology which had reached a kind of peak in England in the late nineteenth and early twentieth centuries had an impact on the way writers viewed the 'primitive' world. In an article titled 'The New Sculpture' in February 1914, Pound railed against modern civilisation and linked the artist's existence to the life of the Tahitian 'savage' while asserting that modern artists were "the heirs of the witch-doctor and the voodoo" (68). Similarly, in the manifesto of Vorticism published in June 1914, Wyndham Lewis described "the art-instinct" as "permanently 'primitive"” and the group's members as " "primitive' Mercenaries in the Modern World" $(30,33)$. By describing the writer in these terms, Modernists were trying to break free from the clutches of late-nineteenth century European realism and naturalism in their work, something which Eliot also aimed to achieve in his drama.

Eliot's concern with the 'primitive' would initially find expression in the short stories of his adolescence. It would develop further with his initiation into the work of the Cambridge Ritualists, a group of anthropologists based largely in early twentieth-century Cambridge, leading ultimately to a theory of drama based on the 'primitive' combination of the lyric and dramatic. In this chapter, I will examine how the ritual theory developed by the Cambridge Ritualists and the influence of Symbolist and other Modernist drama helped Eliot come up with a new aesthetic for an anti-realistic drama, one that used verse to attempt to return drama to its roots. Through an exploration of Eliot's desire for lyric drama one can comprehend the reason for the existence of the lyric-dramatic interaction in his creative works as a whole. I will begin by tracing Eliot's early interest in the 'primitive' and in drama as both of these affected the way he employed anthropology in his dramatic theory.

\footnotetext{
${ }^{1}$ For Picasso's account of the impact of African art on him see Flam, J. and M. Deutch, ed. Primitivism and Twentieth-Century Art: A Documentary History. Berkeley, CA: University of California, 2003, 33.
} 


\subsection{A taste for the 'primitive' in adolescence and an early interest in drama}

Eliot's love of the 'primitive' and exotic displayed itself in his interest in writers from and stories set in different countries and during different periods. His 'A Tale of a Whale' (1905) was located in the South Pacific off the fictional island of Tanzatatapoo (1), while another story, 'The Man Who Was King' (1905), deals with the travels of Captain Jimmy Magruder to Matahiva, a real South Pacific island, part of French Polynesia (18).

The first story is a spoof of American writer Herman Melville's epic novel Moby-Dick (1851). As compared to Moby-Dick, which ends in tragedy for its protagonist Captain Ahab and most of his crew, Eliot's story ends successfully for the whalers involved. 'A Tale of a Whale' has elements of raw (and sometimes black) humour in it as seen when the whalers live off the back of the whale before making off for Honolulu. Eliot's later play Sweeney Agonistes recalls his fascination for the South Pacific in childhood and also includes some of this humour especially when Sweeney threatens to carry Doris off to a cannibal isle (see Crawford 172, Complete 121).

A yearning for exotic lands, peoples and cultures is part of the overall landscape of primitivism and Eliot displayed this craving quite visibly in his adolescent tales. According to Cuddon, "the cultural primitivist [...] finds that peoples isolated from civilization [...] are preferable to those living in civilized and urbanized milieux" (743). Thus, the 'primitivist' writer includes exotic worlds within the dimensions of his writing as it fits in with his belief that a far-off world, distant in terms of geographical and cultural space as well as time, is better than the one at hand.

This can be observed in Eliot's story 'The Man Who Was King' where the narrator lets his readers know about how the French, who arrived after Captain Magruder left the island, had "civilised" the "natives" with religion, thus making them "uninteresting" ('Man' 1). Thus the "natives" are only interesting to the 'primitivist' writer in their original, pristine state. Before the 'civilising' moment, the

\footnotetext{
${ }^{2}$ See Melville, H. Moby-Dick. Evanston: Northwestern University Press (1988), 571-573 for a description of the death of Ahab and the sinking of his ship the Pequod.
} 
narrator describes his protagonist, Captain Magruder, soon after he awakes on an exotic shore after a shipwreck in a manner that is akin to Swift's Gulliver's Travels:

It was several hours before he [Captain Magruder] awoke, to find himself in a rather unusual position. He was being borne on a kind of a litter by two of the islanders, and formed a part of a procession. First marched along the path two natives, who seemed to be priests, by their having more clothes than the rest, sand carrying bowls filled with smoking incense, which had a most unpleasant odor. Next came the two men with the litter and after that a little mob of men beating bhghons (a sort of cross between tin pan and gong) and chanting monotonously. ('Tale' 1-2)

If we ignore the condescending tone of the narrator vis-à-vis the "natives", we have a fascinating description of a fictional ritual which involves both action, in the beating of the drum-like "bhghons", and chanting. In a sense, this early example contains more than a hint of how Eliot would ultimately end up being influenced by the Cambridge Ritualists in seeing ritual as containing aspects of both the lyric and the dramatic. Also interesting is the use of the tin pan since Tin Pan Alley was the centre of most popular music in America at the time and some of the musical and dramatic elements of these songs, which were often performed in vaudeville, entered Eliot's poetry and drama.

The title of Eliot's story is an echo of Kipling's 'The Man Who Would Be King' (1888) which is set in what is now Pakistan. ${ }^{3}$ Like Kipling, Eliot deals with issues of kingship and an impending threat to the king's life; his story has parallels with James Frazer's depictions of the same in The Golden Bough (Frazer 349). This allows us to observe a connection between Eliot's early story and his later passion for anthropology.

Eliot's love for the theatre can be observed as early as January 28, 1899, when as a ten-year-old he announced in his homemade 'magazine', Fireside, that it would contain "Fiction, Gossip, [and] Theatre" (Soldo 13). Drama had an impact on Eliot's student life at Harvard. In the 1909-1910 academic year, he attended Harvard drama professor George Pierce Baker's course titled 'Drama in England from the

\footnotetext{
${ }^{3}$ Kipling, R. 'The Man Who Would Be King.' In Ten Stories. Corbeil: Pan, 1947, 7-49.
} 
Miracle Plays to the Closing of the Theatres', where he "examined those fundamental works of English drama, the medieval mystery plays and the Moralities, from which he was eventually to elicit 'the living past', creating Murder in the Cathedral" (Howarth 139). Eliot's year in Paris as a student in 1910-1911 almost certainly helped him build on his love for the theatre (Hargrove, 'T. S. Eliot and the Parisian' 1). Paris, at the time, was not just full of all kinds of dramatic activity in both realistic and non-realistic modes, but it was also visited by the leading ballet company from Russia. In 1909, a year before Eliot's arrival in Paris, the Ballets Russes (the Russian ballet), under Serge Diaghilev, had made a stunning debut in that city in the Théâtre du Châtelet (Hargrove 'T. S. Eliot and the Parisian' 2). ${ }^{4}$ Eliot referred to Diaghilev and ballet in several of his writings on drama where he was to comment on the importance of ballet to a ritualistic and anti-realistic theatre. Besides this, Eliot was possibly exposed to Wagner's operas or musical dramas either in Paris or Munich in 1911. In a letter written in mid-July 1911, Jean Verdenal, Eliot's friend and fellow lodger in Paris, advised the young poet to "hear something by Wagner in Munich" ("Tâchez donc si possible d'entendre qq. chose de Wagner à Munich") having himself watched Wagner's opera Götterdämmerung (The Twilight of the Gods, 1876) in Paris (Letters 1: 24-25). Eliot's love for Wagnerian opera would find its way into The Waste Land with its inclusion of the sailor lad's song from Act One of Wagner's Tristan und Isolde (Tristan and Isolde, 1865).

On his return to America, Eliot featured in drawing-room productions of theatrical pieces at his cousin, future playwright Eleanor Hinkley's home, a modern ritual intended to provide an evening's pleasure to an intimate audience comprising family and friends. His "first dramatic appearance" involved playing Mr. Woodhouse in a scene adapted by Hinkley from Jane Austen's Emma on February 17, 1913 (Letters 1: 40; Behr 6). Additionally, in 1917 in England, Eliot took on a role in one of the "transvestite plays" written by Lytton Strachey for private performance "by members of the Bloomsbury group (Seymour-Jones 210-211).

Eliot's interest in the dramatic was not confined to the stage alone. In a letter to Hinkley from Oxford, dated October 14, 1914, he drew up a plan for what he called “my great ten-reel cinema drama, EFFIE THE WAIF”, which was initially set in Medicine Hat, Wyoming before it moved to other, more 'exotic' locales such as

\footnotetext{
${ }^{4}$ See also Hargrove, N. D. T. S. Eliot's Parisian Year. Gainesville: University Press of Florida, 2009.
} 
India (Letters 1: 67, 68, 78). As Medicine Hat is associated with a Native American tribe, we may observe Eliot's preoccupation with the 'primitive' at work here as well. By locating the tale in the 'Wild West' of Wyoming and the eastern climes of India, Eliot was catering to his love for the 'exotic' and to his sense of adventure which stemmed from his childhood. He continued to reveal further details of the plan for 'Effie' in letters to Hinkley up to January 3, 1915, after which there is no further mention of the proposed work.

'Effie' was to deal with the tale of an abandoned infant girl discovered on a doorstep by Spike Cassidy "the most notorious gambling house proprietor in the county" (Letters 1:68). The plan for the script has all the elements of melodrama and pre-dates Eliot's later interest in the form as displayed in Sweeney Agonistes. For example, the title of the scene for reel four reads: "YOUR DAUGHTER'S HAND FOR MY SON PETER. OR I DENOUNCE YOU FORTHWITH" (Letters 1: 68). ${ }^{5}$

These lines are supposed to be spoken by Seedy Sam, Spike Cassidy's former partner in an earlier life of crime. Cassidy is now a reformed man and Sam's re-emergence and threat of exposure brings back a sense of fear relating to his past which, in addition to its exaggerated tone, is part of the melodramatic effect of the piece. The hiding of a secret by an important character has often been part of the genre of melodrama.

The tale of an infant abandoned at birth foreshadows the case of the protagonist in Eliot's later play The Confidential Clerk (1953) where Colby Simpkins, suffers a fate, if not similar, then at least containing parallels to that of Effie (Complete 514-515). It also reflects the sentimental drama of drawing-room comedy in England of the nineteenth century, but quite obviously parodies it by using the setting of the 'Wild West' rather than 'cultured' English society.

How serious Eliot might have been about such a scenario we can only guess. In a later letter to Hinkley Eliot elaborated upon the plan for his "cinema drama", discussing the "villainous characters" that fall in love with Effie. These figures included Dancing Bear, "the chief of the Pottawottobottommies" and Traihi Sheik, "the maharaja of Chowwannugger" (Letters 1: 77). While the Potawatomi are an

\footnotetext{
${ }^{5}$ This reel title appears because Eliot was planning, sincerely or otherwise, for a "cinema drama" at a time when the movies were silent and still reliant on a printed page to appear between scenes so as to present audiences with enough of the dialogue or of background to keep the plot going without recorded sound and voices.
} 
American Indian tribe the fact that Eliot distorts their name for the purposes of his plan points to the possibility that the entire scenario was probably a joke that he shared with his cousin. ${ }^{6}$ This seems more likely when Eliot elaborates on his choice of villains in the same letter: "You simply have to have either a red Indian [sic] or an East Indian, and I see no reason why you should not have both" (Letters 1: 77). However, even through the seeming parodies of his interest in anthropology and melodrama and the often patronizing attitude displayed towards the 'natives', Eliot exhibited a genuine interest in 'primitive' societies.

An aspect of Eliot's interest in drama is visible in the mix of voices that arise in his 'Brilliants', short exchanges between characters which appeared in his letters to his cousin. The blend of languages and voices in one of these passages is almost a prelude to what he later attempted in The Waste Land:

\section{BRILLIANTS}

'Est-ce-vous dansez le verrry-mustard?'

HOW did you learn to speak such good English? I'd never know you were a foreigner [... ] (Letters 1: 70)

There is an improvisation or jazz-like quality to the first line in this passage where the speaker invents a term for a dance which does not really seem to exist: the "verrry-mustard". This creativeness is a lead up to a similar style that we see at work in the 'Shakespeherean Rag' of The Waste Land (Complete 65, 1. 128) and in the jazz-inflected language of Sweeney Agonistes.

\subsection{The Cambridge Ritualists}

Following his entry into Harvard in 1906, Eliot gained further insight into the 'primitive' by reading widely in anthropology and 'primitive' religions (Chinitz, T.S. Eliot 73). He displayed evidence in his essays of having noted the work of the Cambridge Ritualists and other anthropologists (see Vickery 233). The most likely date for this acquaintance with anthropological work was from late 1911 or early

\footnotetext{
${ }^{6}$ See http://www.native-languages.org/potawatomi.htm (accessed 17 March, 2010) for information about the tribe.
} 
1912 to 1915 (Vickery 237). The Cambridge Ritualists, including Jane Harrison and Gilbert Murray, explored the possibility of a link between drama and ritual. Harrison's Themis (1912) tied Dionysian rituals to the stirrings of Greek tragedy and this, along with Murray's work, gave rise to the ritual theory of drama which was to have an important impact on Eliot's own dramatic theory (Carpentier 5).

Harrison derived her understanding of the origins of tragedy from Aristotle's statement in Poetics, one we have already seen, that the form had started with "the authors of the Dithyramb" (19). For Harrison, the dithyramb was a paean sung in honour of the birth of Dionysus making it part of ritual (Themis 32). Thus, she contended that art (tragedy) arose out of ritual: dithyrambs performed at the Spring Festival in Athens (Harrison, Ancient 118). Harrison's claim that the dithyramb was originally a song linked it to the lyric. However, importantly the dithyramb was also a dance, thus connecting it to drama as both of these forms involved action. Thus Harrison made interconnections between lyric, drama and ritual (an important aspect of 'primitive' society) as derived from Aristotle. Ritual possessed both lyric and dramatic aspects, and in this respect it represented, for Eliot, a return to a time when there was no differentiation between the two forms. Eliot was to later make use of Harrison's ideas in his dramatic theory as when he suggested that "the Greek drama develops out of religious rites, and remains a formal public ceremony associated with traditional religious celebrations" (On Poetry 16).

Eliot specifically used theories from another Cambridge Ritualist, F. M. Cornford, as a framework for Sweeney Agonistes. Just as Harrison had employed Aristotle's description of the origins of tragedy as a starting-point for her theories, Cornford, in The Origin of Attic Comedy (1914), adopted the Greek writer's version of the origin of comedy as his basis for a description of comedy. Aristotle had stated that comedy, like tragedy, was initially "mere improvisation" and that it originated with the authors of "phallic songs" (19). Cornford reiterated Aristotle's description and held that comedy arose from Dionysiac or Phallic ritual (Cornford 3). Thus, the Ritualists perceived the same pattern working in the case of both tragedy and comedy, that is: a song (lyric), which was originally part of ritual, gave rise to drama. This was essentially what Eliot accepted for his theory of drama. 


\subsection{Eliot's anti-realism in the drama}

While Eliot perceived the ritual elements of theatre which "ally it with poetry", he believed that it was drama's realistic elements that became a burden for the writer (Skaff 101). This, too, was a position shared by the Cambridge Ritualists: Harrison attacked realism and naturalism by condemning the idea of art as "the close and realistic copy of Nature" (Ancient 22). Eliot echoed her dislike. Part of his reason for turning towards the ritual theory of drama was his antagonism against the use of realism in the theatre. From 1920 onwards, he attacked the social drama of George Bernard Shaw and the realistic drama of Henrik Ibsen and Anton Chekhov before finally launching into an all-out assault on realism on the stage in 'Dramatis Personae':

The realism of the ordinary stage is something to which we can no longer respond, because to us it is no longer realistic. We know now that the gesture of daily existence is inadequate for the stage; instead of pretending that the stage gesture is a copy of reality, let us adopt a literal untruth, a thorough-going convention, a ritual. For the stage - not only in its remote origins, but always - is a ritual, and the failure of the contemporary stage to satisfy the craving for ritual is one of the reasons why it is not a living art.

('Dramatis' 305-306)

For Eliot, realism's failure to satisfy the need for ritual on stage had its roots in the absence of the lyrical in modern drama. In his essays, he attempted to link the lyric and dramatic to ritual and ultimately to dance and rhythm. These were elements that he sometimes discussed separately in his early essays but later put together to form a theory of drama that would be opposed to realistic drama. This linking of the lyric and dramatic in Eliot's essays would be reflected by an attempt to bring the two together in his creative work. 


\subsection{Alternatives to realism in the theatre}

\section{Symbolists, puppets and masks}

In order to come up with an alternative to realism in the theatre, Eliot primarily subscribed to the ritual theory of drama propounded by the Cambridge Ritualists. However, he also encouraged certain dramatic practices and theories which had already been employed or discussed by certain playwrights in Europe and elsewhere in the late part of the nineteenth century or even before that. These included the Symbolist theories of drama and acting developed in late nineteenth-century France, the use of masks suggested initially by the Japanese Noh and ancient Greek plays, and the use of puppets as called for by British dramatist Gordon Craig in the early part of the twentieth century. Besides these, Eliot also stressed the importance of dance, specifically ballet, the music-hall and the Church in his attempt to come up with the parameters for a new drama, one which would incorporate a sense of ritual in order to combat realism on the stage.

An important aesthetic for the non-realistic theatre on the European continent was developed by the Symbolists in Paris beginning around 1885 (Charvet 90). Much before Eliot considered bringing poetry back to the stage, Stéphane Mallarmé, the leader of the Symbolist movement in France, had already stressed the use of poetic language in the theatre. The Symbolists, too, wished to reintroduce poetry to the stage as a reaction against realism.

While Eliot criticised realism in drama for its lack of lyricism, he also criticised the Symbolists for the lack of dramatic qualities in their plays. Even as the Symbolists tried to reintroduce the lyrical onto the stage, Eliot believed they may have gone too far and made things worse for the proponents of poetry in drama. As opposed to the Symbolists who indulged in 'producing' closet drama, plays written only to be read, Eliot insisted on theatre as primarily a performative art. In his review of the production of Webster's The Duchess of Malfi_at the Lyric Theatre, for example, Eliot distinguished between "acting plays" and "closet drama": "Acting plays may be good, or defective, or hopelessly dull; but their dulness has a wholly different tone from the dulness [sic] of the closet drama. The dullest, the most theatrically inept, of acting plays will be readable if it only has a few good lines, but 
the closet drama is wholly unreadable" ('The Duchess' 36). Clearly, Eliot sought a poetic drama that was performance-based.

Other theatre movements of Eliot's time also employed poetry mainly as a reaction against realism. The Dadaists and Futurists busied themselves in reading poetry from the stage to mixed responses. In Ireland, Yeats produced poetic plays which employed the style of the Symbolists while using Celtic myth for its themes. Yeats, who was early on influenced by the Symbolists, later came under the spell of the Japanese Noh drama when he used masks, dance, music, and chant in his plays in England (Esslin 359; Brockett 449). Eliot's own interest in Noh and Yeats' poetic plays reached a peak in 1917 . He especially remembered the première of Yeats' play At the Hawk's Well in the same year, which featured "a celebrated Japanese dancer in the role of the hawk" (Smidt 22). In fact, Eliot wrote to Hallie Flanagan before the first production of Sweeney Agonistes at Vassar in America, telling her that he wanted the action of the play "stylised as in the Noh drama" and asking her to read the notes to Pound's book on the Noh and Yeats' preface to At the Hawk's Well (Flanagan 83). Obviously, Eliot borrowed ideas for his play from Pound and Yeats who, in turn, imitated a very ancient and, in that sense, 'primitive' Japanese theatre tradition.

Eliot's ideas about acting and staging techniques also seem to have been borrowed from Symbolist beliefs and performances and from ritual theory. As a critic, he did not want to be dependent on the actor partly because he believed in the idea that the group, as described by anthropologists, including Harrison, was more important than the individual in a performance (Harrison, Ancient 36-37). Eliot referred to the "instability of any art - the drama, music, dancing - which depends upon representation by performers" (Sacred 69). He claimed to be distressed that the actors in the Phoenix Society's 'revival' of The Duchess of Malfi had tried to "improve" on the poetry for, he asserted, "there is no such thing as the interpretation of poetry; poetry can only be transmitted"' ('The Duchess' 39).

Eliot echoed the ideas of the Symbolist dramatists who went to the extent of using a gauze scrim in Pierre Quillard's passion play The Girl with Cut-Off Hands (1891) to avoid the "distraction" caused by the actor's individuality in the theatre 
(Deak 24-25). ${ }^{7}$ This seemed in line with Symbolist playwright Maurice Maeterlinck's diktat that the live actor should be replaced by a shadow since, according to the Symbolists, an actor's individuality always marred his stage presence (Deak 24-25). Eliot believed that the ideal actor for a poetic drama was one “with no personal vanity" ('The Duchess' 39). This was the reason why the Symbolist dramatists displayed an interest in puppets which, unlike actors, did not have a life of their own. We can see how this would link up to Eliot's attempts to find out more about using puppets in his plays instead of actors and his discussion of Craig's suggested use of Übermarionettes or 'superpuppets' to replace stage actors ('London Letter', Aug. 1921, 214; Brockett 442). On 23 August 1923, Eliot also wrote to Alfred Kreymborg, an American writer of puppet plays, asking about how to build a puppet theatre "on a box small enough to stand on a table $3 \times 3 \mathrm{ft}$ - and preordain every move and gesture and grouping" (Letters 2:192). This interest in puppets can be first observed in Eliot's use of marionettes in his early poems such as 'Humouresque' (1909) and 'Convictions' (1910).

Another stylistic element which Eliot ultimately sought to borrow from the Symbolists and from Noh drama was the use of masks. Eliot impressed on Flanagan that the characters in Sweeney Agonistes "ought to wear masks" and he had already seen Yeats using masks in his imitation of the Noh (Flanagan 83). Yeats himself had been influenced by the Symbolists in his use of masks. He had attended the first performance of Alfred Jarry's Ubu Roi in 1898 where actors wore masks and were each made to speak in a particular tone to nullify the effect of the individual's personality (Deak 227). ${ }^{8}$ Masks were part of an ancient tradition brought down from the ancient Greeks and the Japanese (in the case of the Noh) and they point us back to the interest in primitivism in Eliot. The use of the mask in the Greek dithyramb might have been one of the reasons why Eliot was attracted towards it, since it points back to a time when lyric and drama were part of one performance. The mask allowed performers to conceal their individuality and placed theatre at a distance from realism while ensuring the creation of stock-types as in Noh drama. This subservience of the singular personality to the greater community can be interpreted

\footnotetext{
${ }^{7}$ Quillard, P. and J. F. Hovis. "The Girl with Cut-Off Hands: A Passion Play." The Drama Review 20.3 (Sep. 1976): 123-28.

${ }^{8}$ Jarry was not strictly a Symbolist even though the première of $U b u$ Roi was seen as a part of the Symbolist movement. His drama was a precursor to Surrealist and Absurdist theatre.
} 
as part of Eliot's understanding of totemism in 'primitive' cultures, where the group is more important than the individual and also links up to his ideas regarding the use of a Chorus. The mask, being an integral element of ritual, would definitely be of interest to Eliot in his quest for a ritual drama.

\section{The music-hall, the Chorus and cinema}

Eliot enjoyed and regularly attended the music-hall in London which was a tradition handed down from nineteenth-century Britain and was still alive in the early twentieth-century. He brought the conventions of the music-hall into his discussions of dramatic theory from 1920 onwards. While claiming that there was a need "to take a form of entertainment, and subject it to the process which would leave it a form of art" Eliot suggested that the music-hall comedian provided the best material for this purpose (Sacred 70).

By pointing to the music-hall as source material for modern verse drama Eliot was looking at introducing popular art forms into drama to provide an alternative to realism. What was important for him was the interaction between the music-hall performer and his audience. In his 'London Letter' of June 1921 Eliot indulged in a description of the Lancashire music-hall comedian who "disappears" with the advent of the "more lucrative Cinema" (688). Here, Eliot examined the relation between the music-hall performer and his audience for the first time: "success depends upon the relation established by a comedian of strong personality with an audience quick to respond with approval or contempt” ('London Letter', Jun. 1921, 688).

This seems like a modern version of an ancient ritual with everyone participating, what Chinitz calls the "English tribal ritual" ('T.S. Eliot' 239). The interaction between the performer and audience in the music-hall corresponded to a similar process in early ritual since there was no distinction between the priest (performer) and the believers or participants (audience) of a ritual. As Eliot stated in his essay on the famous music-hall artiste Marie Lloyd, the working man was "himself performing part of the act; he was engaged in that collaboration of the audience with the artist which is necessary in all art and most obviously in dramatic art" (Selected 420). 
Thus one can see that art becomes, like ritual, an inclusive process, a group effort, one that involves both performer and audience. As Chinitz puts it, in his description of Eliot's beliefs, "Art was not a solitary exercise but a public activity, one in which the entire tribe participated" (T.S. Eliot 73). It was this ritualistic element of music-hall which made Eliot want to use its elements in verse drama, especially since the prevalence of ritual and music in music-hall could allow for greater lyricism in the drama.

Eliot's love for music-hall may have had something to do with his belief in totemism which was derived from his readings in anthropology. He discussed totemism in his review of Émile Durkheim's Les Formes Élémentaires de la Vie Religieuse (The Elementary Forms of Religious Life, 1912), seeing it as a binding factor which brought the group together (Eliot, 'Durkheim' 24). Eliot would also place the 'savage' between two worlds, one of "drudgery" and the other, a "sacred" world which was intense and to which he could "escape at regular intervals" ('Durkheim' 24). This sacred world seems to be best discovered in communion with others of the tribe. We can observe a parallel with what Eliot looks for in the musichall and audience participation in the essay on Marie Lloyd and make a link between totemism, group awareness and the sense of tradition displayed in 'Tradition and the Individual Talent' (1919).

In the latter essay, Eliot insisted that, "No poet, no artist of any art, has his complete meaning alone. His significance, his appreciation is the appreciation of his relation to the dead poets and artists" (Selected 15). The importance of such an understanding to Eliot's artistic beliefs is underscored by the presence of a corresponding statement in his 1916 review of Durkheim's work: "For the savage or the civilised man, a solely individual existence would be intolerable; he feels the need of recreating and sustaining his strength by periodic refuge in another consciousness which is supra-individual” ('Durkheim' 24).

Eliot's beliefs about the importance of the group over individual consciousness were partly derived from anthropologist Wilhelm Wundt, whose book Elemente der Völkerpsychologie (Elements of Folk Psychology, 1912) the poet reviewed in January 1917. Wundt placed great emphasis on the role of the group as compared to the individual in the beginnings of art and of mythology (2). Eliot also borrowed his conception of individuality and the 'savage' from Harrison, who claimed that: 
The individual among savages has but a thin and meagre personality [...] it is what the tribe feels that is sacred, that is matter for ritual. He may make by himself excited movements, he may leap for joy, for fear, but unless these movements are made by the tribe together they will not become rhythmical; they will probably lack intensity, and certainly permanence. (Ancient 36-37)

Thus it was the collective consciousness that was of importance to ritual and the origin of dance and, ultimately, to drama. As Harrison asserted it was "in the common act, the common or collective emotion, that ritual starts" (Ancient 126). The "common act" implied the surrender of the self. In "Tradition and the Individual Talent', Eliot's description of the poet's desire to develop his consciousness of the past as a kind of surrender, "a continual self-sacrifice", was a very "primitive" form of action described by anthropologists of his time (Selected 17$){ }^{9}$

Harrison's arguments about the importance of the group or the ensemble highlight the significance of the Chorus in the verse drama. Harrison pointed to the importance of the Chorus when she described the dromenon or ritual from which the dithyramb arose as "a thing which, like the drama, is collectively performed" and that its basis was the "thiasos or choros [choral dance]" (Themis Xv). It was the Chorus as a group effort which was "the centre and kernel and starting-point of the drama" (Harrison, Ancient 123-124). We can thus understand the importance of the use of the Chorus in Eliot's own plays as borrowed from the ancient Greek, the Noh drama or even from the music-hall tradition.

The ancient Greek Chorus, as we know, indulged in choral odes, chanting and songs. Here, we can uncover perhaps another reason for Eliot's interest in music or the lyrical in drama. The music of the Chorus ultimately led to the drama of tragedy, according to Nietzsche who claimed that "tragedy arose from the tragic chorus" (36).

Nietzsche's comments on tragedy and dance are interesting in the light of his connections with German composer Richard Wagner and Eliot's use of Wagnerian music in The Waste Land. Wagner himself would be seen to be a forerunner of Modernism through his attempts to enrich drama through music and myth (see Brockett 421). In fact, Eliot's ideas about blending different theatrical forms and

\footnotetext{
${ }^{9}$ See Frazer's chapter on the 'Sacrifice of the King's Son' in The Golden Bough, 381-386 for an example of this.
} 
ritual together to create a new kind of verse drama sounds close to the Wagnerian concept of Gesamtkunstwerk which involved a theatre that included the mixing of drama, music and other performing arts (Brockett 421-422). Just as Wagner was keen to employ music in the theatre, Eliot sought to employ poetry and music in the drama. To this end, Eliot saw the use of music-hall and music as ways in which to counter realism on the stage.

In his writings on the music-hall Eliot revealed his attitude towards cinema which was part of his anti-realist agenda in drama. The reason for Eliot's antipathy towards cinema was the perceived link that he saw between film and realism. In 'Marie Lloyd' he sounded extremely ambivalent when dealing with the "problem" of cinema, simultaneously belittling its importance and regretting its absence: "There are no cinema records of her [Marie Lloyd]; she never descended to this form of money-making; it is to be regretted, however, that there is no film of her to preserve for the recollection of her admirers the perfect expressiveness of her smallest gestures" (Selected 419). But perhaps, such an observation was not so ambivalent after all. Through it Eliot seemed to reveal a belief that the cinema, if involved in art at all, was only meant to be a recording tool, and not a medium for new artistic endeavour itself.

Eliot was chiefly afraid that with the advent of cinema, the participation of the group (the audience) in music-hall would disappear and the sense of ritual would be lost forever. With the disappearance of ritual he might also have feared the vanishing of the lyric from performance. To this extent some of Eliot's plays involve the participation of the audience perhaps in order to maintain some of the ritual elements of the drama. This is especially so in the music towards the end of The Rock (86) and also in the processions through the audience at the end of Murder in the Cathedral (Complete 281-82).

\section{Dance and rhythm}

Dance, specifically ballet, provided another means by which Eliot wished to create an aesthetic opposed to realism in the theatre. In 1928, he claimed that ballet provided a form of askesis, something involving strict discipline and self-control, for actors (Selected 47). His yearning for this discipline was connected to his theory of 
acting based on fixed or ritualistic patterns. In 'Four Elizabethan Dramatists' (1924) Eliot praised the ballet dancer as a "conventional being, a being which exists only in and for the work of art" (Selected 113). As such, the fixed patterns and movements of ballet fitted in well with Eliot's idea of a "strict form of drama" which was different from realistic drama where "the human being intrudes" (Selected 113).

Eliot's interest in dance most probably developed in Paris where the 1910-11 season featured performances by Sergei Diaghilev's Ballets Russes and Isadora Duncan (Hargrove, 'T.S. Eliot and the Dance' 61). Eliot loved dancing as a social activity and regularly attended ballet performances over the years. $\mathrm{He}$ "saw 'Carnaval', 'The Firebird' and 'The Good-Humoured Ladies', performed by Diaghilev's Company with Massine and Lydia Lopokova” in 1919 (Letters 1: 347, n 1). In his essays, from 1920 onwards, Eliot discussed dance and ballet, alongside music. He combined his interest in dance with his concern for the 'primitive' and poetry to come up with a theory of poetic drama based largely on ritual.

Why was Eliot so interested in the ballet? The answer may lie in the fact that like the dithyramb or the phallic songs which the Cambridge Ritualists believed were the origin of drama, ballet was a mix of music and dance. If we view music as originally linked to the lyric and dance as being connected to drama, then Eliot's reasons for an interest in the ballet become clearer. Ballet provided, in its own way, the same mix of poetry and drama that Eliot would yearn for on the modern stage, and presented it within an art form that, according to him, had "primitive" origins. Eliot believed that in order to "penetrate to the spirit of dancing" and to understand what the future of ballet may be, it was necessary to begin with a "close study of dancing amongst "primitive" people" ('Ballet' 441). By linking dance to primitivism Eliot was not far from linking it to both the lyric and dramatic.

Wundt, too, was convinced that for 'primitive' humans, dance was the best form of artistic expression, since he believed humans were naturally endowed for it (94). Eliot may have also borrowed the idea of the importance of the drum used in his essay 'The Beating of a Drum' from Wundt's description of this instrument as being "common at a very early time" (Wundt 95). Additionally, Wundt's account of the dance-song as musical accompaniment for the dance provided by the voice could also have affected Eliot's perceptions on the need for both dance and music as integral parts of drama (Wundt 95-96). Thus, in Wundt, we find the perfect example 
of a descriptive mix of lyric poetry and dance in 'primitive' times that could have aided Eliot's construction of a ritual theory for modern drama.

For perhaps the first time Eliot connected both drama and poetry with dance when he claimed that it was important for the verse dramatist to "obtain, with verse, an effect as immediate and direct as that of the best ballet' ('Duchess' 39). In his 'London Letter' of August 1921, he maintained that the ballet would "probably be one of the influences forming a new drama" (214). This claim was to be repeated in 'A Dialogue on Dramatic Poetry' (1928), where importantly one of the speakers asks, "If there is a future for drama, and particularly for poetic drama, will it not be in the direction indicated by the ballet?" (Selected 46) Clearly Eliot wished to make dance an integral part of his anti-realistic theory of drama. His interest in the ballet was an essential part of his desire to return to theatre's 'primitive' origins as revealed in his review of a performance of Stravinsky's Le Sacre du Printemps, where he claimed that the "spirit of the ballet was 'primitive' ceremony" ('London Letter', Oct. 1921, 453).

Eliot sought to use rhythm, which he saw as central to art, to connect three of his major interests up to this point: dance, drama and ritual. Of prime importance here is Eliot's statement that: "The drama was originally ritual; and ritual, consisting of a set of repeated movements, is essentially a dance ('The Beating' 12). Clearly he borrowed here from the Cambridge Ritualists' ideas on the dithyramb and phallic songs which, in turn, were taken from Aristotle. The "set of repeated movements" is essentially rhythm, a fixed form of recurrent patterns. Hence, rhythm could act as a link between ritual, dance and drama, three elements that were vital to Eliot's theory of poetic drama. Rhythm appeals to the body, thus connecting it to drama, but it is also evident in the measures of poetry. Eliot explored the reasons among different societies for the use of a drum; that was the need for rhythm. He bemoaned that modern man had "lost the drum" (Eliot, 'Beating' 12). His quest through verse drama then could be seen as an attempt to rediscover that "lost drum", the primal beat which sparked the first light of performance art in the ancient world (C. Smith 49). 
Another way in which Eliot was to take on the realistic drama of the day was through the use of the drama of the Mass. His ideas for such a drama were partly derived from Harrison's writings. When Harrison claimed that it was "one and the same impulse that sends a man to church and to the theatre" she was referring to the need for ritual (Ancient 10). She lamented the fact that art and ritual, which were so fused together in ancient times, had "diverged to-day" (Harrison, Ancient 9). In Reminiscences of a Student's Life (1925), she claimed that while "the ritual dance is all but dead [...] the ritual drama, the death and the resurrection of the Year-Spirit, still goes on". Harrison's example of this living ritual drama was the Russian Mass that still substantially followed "the Greek rite" (Reminiscences 86). Like Harrison, Eliot saw ritual, dance and drama coalescing in the Mass. This became increasingly the case as he neared his conversion in 1927. Across several essays he made a comparison between the Mass and each one of these elements which could be seen as central to his dramatic theory, believing that the ballet and the Mass were the highest forms of dance ('Ballet' 441). Considering that he then went on to assert that a study of the 'primitive' element in dance was essential, he seemed to make connections between a 'savage' past and the more modern Mass.

In 'A Dialogue on Dramatic Poetry', Eliot declared, through the character of E, that "the perfect and ideal drama, is to be found in the ceremony of the Mass" and that the "drama sprung from religious liturgy" (Selected 47). Here we can observe an extension of the idea Eliot expressed in his introduction to Savonarola, where he claimed that "dramatic form" possibly occurs "at various points along a line the termini of which are liturgy and realism" (x). As with everything else, he was looking for a via media for drama, a middle path between ritual and realism. This again has parallels with his interest in a connecting bridge between lyric and drama. As liturgy is basically a ritual which contains both lyric and dramatic elements, the tension between liturgy and realism that Eliot refers to could be seen as paralleling the synergy between poetry and drama in his works. This is hinted at in Eliot's statement that "in genuine drama the form is determined by the point on the line at which a tension between liturgy and realism takes place” (Introduction, Savonarola $\mathrm{x})$. 
Eliot would thus link drama to liturgy in a manner reminiscent of Harrison's insistence on the link between art and religion. These connections were the basis for the use of a particular literary form or type of drama, one that included poetry and ritual. As we have already observed, Harrison argued that ritual was the bridge between religion and art, and that art sprang from religion (Reminiscences 84). This idea was paralleled by Eliot when he connected the Fool in King Lear with "the shaman or medicine man", thus making a direct link between drama and 'primitive' religion: "The Fool in "Lear" is a possessed; a very cunning and very intuitive person; he has more than a suggestion of the shaman or medicine man" ('Beating' 11). While Eliot here seems to be propagating the stereotype of the 'native' as "cunning" by nature and more "intuitive" than Europeans, what is more interesting, for this thesis, is the parallel he draws between a figure from Elizabethan theatre and one from 'primitive' ritual. Like the shaman during 'primitive' religious rituals, the Fool performed the 'rituals', wore the garb and spoke the language, essential for the drama.

Thus we can see how Eliot who had previously made connections between 'primitive' religion and drama was later discovering links between the liturgy of a relatively modern religion (Christianity) and drama. The common factor in this binding of religion, whether 'primitive' or modern, to art was ritual. It is no surprise therefore to find Eliot later taking up the writing of religious drama in a serious manner in The Rock and Murder in the Cathedral. We shall consider this shift in his dramatic theory and its implications on the lyric-dramatic interrelationship on Eliot's oeuvre more closely in chapter five.

\subsection{Language and form for a modern verse drama}

In 'The Poetic Drama' (1920) Eliot emphasized that the natural evolution for future verse dramatists would be in the direction "indicated by Browning" (635). This is significant given Eliot's indebtedness to Browning for the use of the dramatic monologue in his own poetry. Here, we see Eliot trying to make use of the 'tradition' in a new and exciting fashion. He claimed that he wished "to distil the dramatic essences" from Browning "and infuse them into some other liquor" (Eliot, 'Poetic' 635). Eliot's quest for a poetic drama is a quest for form as he blames a "formless 
age" for the "incompetence of our time in poetic drama" (Sacred 64). This is in direct contrast to what he believed was the great form of the Elizabethan Age, blank verse, "which imposed itself on everything that came to it" (Sacred 62). Yet, Eliot asserted, "The essential is not $[\ldots]$ that drama should be written in verse $[\ldots]$ the essential is to get upon the stage this precise statement of life which is at the same time a point of view, a world [...]" (Sacred 68). He believed that, in the theatre, it was poetry rather than realism which was more capable of presenting the "precise statement of life."

Eliot confirmed this view in his essay on 'John Dryden', where he stated that it was "the pure magnificence [...] of poetic diction" that gave life to Dryden's plays (362). Similarly, in 'Metaphysical Poets', Eliot praised the dramatic verse of "the later Elizabethan and early Jacobean poets" which, he believed, "expresses a degree of development of sensibility which is not found in any of the prose [...]" (669) Subsequently, it is not surprising to find Eliot employing of some of the rhythms and language of Elizabethan and Jacobean drama in his own poetry and drama. Many of his views on verse drama came together in 1926, in the introduction to Savonarola, which was also the year that the first part of Sweeney Agonistes appeared as 'Fragments of a Prologue'. Two years later, in 1928, Eliot made a crucial statement that encapsulated his thoughts on the bringing together of the lyric and dramatic when he wrote, "All poetry tends towards drama, and all drama towards poetry" (Selected 52).

Eliot's battle with realism on the stage stemmed from his belief that it killed off poetry on the stage just as his differences with the Symbolist dramatists arose from a sense that they had reduced the dramatic nature of the theatre itself while espousing the cause of the poet. He aimed, therefore, to discover a balance between poetry and drama on the stage, so that neither form would prove detrimental to the other in the long run.

\subsection{Conclusion}

In his discussion on Eliot's use of the 'primitive', Manganaro says: "By returning to the 'savage' Eliot is only [...] widening his 'assimilative grasp', making use of materials from the extreme end of his broadly comparativist field of vision" (98). 
While it might be true that Eliot's 'savage' is a construction of his imagination, a "highly-skewed representation designed by the poet-critic to meet his own poetic and critical needs" (Manganaro 91), it is also certain that the artist's conception of the 'primitive' was central to his theory of poetic drama. Eliot viewed the 'primitive' as a kind of binding glue which combined the lyric and the dramatic in a new style that would provide an alternative to the realism of Ibsen, Shaw and Galsworthy and reintroduce the poetic element into drama. While his first overt experiment in this respect was Sweeney Agonistes, The Waste Land was a definite step towards achieving this goal. The dramatic nature of The Waste Land stemmed from Eliot's need to include ritual in his poetry before using ritualistic elements in his drama.

I will now examine the presence of the dramatic in Eliot's poetry up to The Waste Land in order to see how his literary career built up to the moment of the crossover from poetry to poetic drama, and examine whether this crossing was implicit in his poetry. 


\title{
Chapter Two: Romantic Irritations and Dramatic Aspirations: Plotting the Dramatic in Eliot's Poetry before The Waste Land
}

\subsection{Introduction}

Writing about the development of the dramatic in Eliot's poetry, Grove maintains:

\author{
It won't do [...] to think of his [Eliot's] plays as a fading comet's- \\ tail, or a remnant left over after his true career. It might even be \\ better to consider the printed verse as itself a series of gestures, \\ speeches, quasi-theatrical occasions - beginning with the titles \\ ('The Love-Song of J. Alfred Prufrock'), and going on through \\ monologues, ensembles, scenes in the pub, the rose-garden and \\ the rest. (160)
}

\begin{abstract}
As Grove observes, beginning around 1909, Eliot's poetry reveals a number of dramatic elements which points to a connection with his later drama. His poetry, from this time on, was very different from the neo-Romantic poetry that he had penned in his adolescence. Eliot was not, in the beginning, an anti-Romantic poet, but strove to become one consciously. In what were essentially fragments of a plan for an early poem (undated and untitled) he prayed,
\end{abstract}

O lord, have patience

Pardon these derelictions -

I shall convince these romantic irritations

By my classical convictions. (Inventions 83, 11. 1-4) 
The struggle to do away with his initial Romantic yearnings was just that, a struggle. From 1909 onwards, Eliot's battle against "romantic irritations", his interest in theatre and the influence of the nineteenth-century French poet Jules Laforgue led him to introduce performance elements from vaudeville and minstrel shows in his poetry and to create characters that were part of monologues or were involved in dialogue, a crucial element of drama. While Eliot's adoption of an anti-Romantic pose may have been akin to a mask that he donned during his early career and took off at a later stage he undoubtedly displayed such a stance up to the mid-1920s and this affected the nature of his poetry infusing it with dramatic qualities. ${ }^{1}$

Eliot expressed a desire for a new kind of poetry in his early critical writings where he wished to dispense with Romantic 'excesses' by objectifying emotion. In his 1919 essay on Hamlet he asserted,

The only way of expressing emotion in the form of art is by finding an 'objective correlative'; in other words, a set of objects, a situation, a chain of events which shall be the formula of that particular emotion; such that when the external facts, which must terminate in sensory experience are given the emotion is immediately evoked. (Selected 145 )

This "adequacy of the external to the emotion" was, according to Eliot, precisely what Hamlet lacked (Selected 145). He sustained his attack on the Romantics when he repudiated Wordsworth's theory of poetry as either a turning loose of emotion or the expression of personality (Selected 21). These ideas were expressed after Eliot had begun to introduce the element of 'objectivity' in his poetic works. The reason for his assuredness in his early criticism resided in the fact that he was already practising what he preached in poetry; he was essentially defending his poetry through his criticism. Eliot finally acknowledged this fact as late as 1964 when he revealed that, in his early criticism, he was "implicitly defending the sort of poetry that I and my friends wrote [sic]" and that he was "in reaction, not only against Georgian poetry, but against Georgian criticism" (To Criticize 16). Eliot considered

\footnotetext{
${ }^{1}$ Bornstein claims that Eliot "posed as an anti-romantic modern" (94).
} 
the sentimentalism of the Georgians, poets of the early part of the twentieth century, to have been derived from Romanticism.

While Bornstein suggests that "the romantics became chief casualties of Eliot's reaction against Georgians" (105), what is important for this study is the knowledge that Eliot's anti-Romanticism and anti-Georgianism were factors that led him to include more of the dramatic in his poetry from 1909 onwards. The use of the dramatic meant that, unlike the Romantics, emotion became objectified in Eliot's verse causing him to employ a method that was anti-Romantic and avant-garde much before he met other Modernist poets such as Pound in 1914.

In this chapter I will examine Eliot's poetry before The Waste Land to discover what dramatic elements come to the fore in them, how they do so and what implications the presence of such elements have for his later work. While trying to follow the influences upon his work I will refer to the dramatic elements described in the introduction. Just because I seek to examine the dramatic in his poetry does not mean that all his poetry of this era has dramatic elements and that the dramatic dominates throughout these poems. There are several instances where Eliot actually holds back from being too overtly dramatic in the poems and other instances where there are almost no dramatic elements at all. However, by examining the dramatic elements in his poetry where they do exist we can begin to appreciate the lyricdramatic interface at work in these poems.

\subsection{The dandy and ironic splitting}

Up to 1908 Eliot indulged in traditional lyrics written in a Romantic style. As Bornstein puts it, his poems of this period largely contain "regular metres, tone, and themes" which "belong to the butt end of subjective or aesthetic nineteenth-century traditions" (98). This can be seen in one of Eliot's earliest poems 'A Lyric: If Time and Space as Sages Say' (1905) which employs pastoral imagery, conventional rhyme schemes and archaic language in a manner that conforms to late Victorian and Edwardian poetic styles. This is not surprising given that Eliot was only seventeen at the time and had yet to come under the influence of Laforgue and his fellow French poet Charles Baudelaire: 
The flowers I gave thee when the dew

Was trembling on the vine,

Were withered ere the wild bee flew

To suck the eglantine.

So let us haste to pluck anew

Nor mourn to see them pine,

And though our days of love be few

Yet let them be divine. (Complete 590, 11. 9-16)

'A Lyric' contains echoes of the Metaphysical poet Andrew Marvell's 'To His Coy Mistress' with its 'carpe diem' theme borrowed from Renaissance poets and its shared parody of this theme. Eliot would later be influenced by the Metaphysical poets in his general turn away from neo-Romanticism. However, at this stage, Eliot still employs pastoral imagery, like the neo-Romantics. He differs from them in that the flowers in his poem are not in bloom but are already decayed. Seen in this light his early poetry seems to possess some characteristics of Baudelairean poetry and the Decadent poets of the late 1890s in England. Baudelaire had described his poems in the dedication to Les Fleurs du Mal (The Flowers of Evil, 1857) as "ces fleurs maladives" or "these flowers of sickness" (Flowers 51). Eliot's poem displays a predilection towards the theme of decay in a style that is only slightly Baudelairean at this stage. In any case, this early example bears all the marks of lyricism in poetry, and, as yet, little or none of the dramatic.

Something similar happens in 'Song: When We Came Home Across the Hill' (1907). Here, Eliot juxtaposes a fecund natural world against the couple's fading love. The decay and disintegration of human love in the poem occurs against the backdrop of nature's abundance:

The hedgerow bloomed with flowers still,

No withered petals lay beneath;

But the wild roses in your wreath

Were faded, and the leaves were brown. (Complete 596, 11. 5-8) 
Here, Eliot describes hedgerows, an image that Wordsworth had famously used in 'Tintern Abbey' in the lines, “Once again I see / These hedge-rows, hardly hedgerows, little lines [...]", and remains largely in neo-Romantic mode (Wordsworth 67, 11. 14-15). The lyric speaker in Eliot's poem appears to treat his lady love with the respect and care that one does not observe in his poems after 1908, when he moved towards the misogynistic decadence characteristic of Baudelaire and Laforgue. This shift would be partially responsible for infusing a sense of modernity and irony into his poetry and led later to an introduction of dramatic elements as well. In order to part ways with the Romantic lyric Eliot had to develop a new aesthetic for his poetry which he devised from his reading of Baudelaire and Laforgue. The influence of Baudelaire initially caused Eliot to turn away from the Romantic concept of nature as benign and beautiful allowing the young American to uncover its malevolent side:

This morning's flowers and flowers of yesterday

Their fragrance drifts across the room at dawn,

Fragrance of bloom and fragrance of decay,

Fresh flowers, withered flowers, flowers of dawn.

(Complete 597, 11. 5-8)

Conventionally associated with freshness and new life, dawn here bears with it a sense of inevitable doom which echoes Baudelaire. Eliot also borrowed from Baudelaire his depiction of women as evil. In 'Circe's Palace' (1908), Eliot presented his version of the Greek myth of Circe, the nymph who trapped men and transformed them into tame animals:

Around her fountain which flows

With the voice of men in pain,

Are flowers that no man knows

Their petals are fanged and red

With hideous streak and stain;

They sprang from the limbs of the dead -

We shall not come here again. (Complete 598, 11. 1-7) 
The words here are recited either by a group of male speakers comprising Odysseus and his men who escaped death at the hands of Circe or a single speaker who could be Odysseus addressing his men. The presence of the first-person plural "we" indicates a desire to include the reader or audience in the action or setting of the poem, in other words, an instinctive move towards the collective nature of ritual and drama.

The violence of Circe's world where the blood of men who have been killed manifests itself in petals that are "red / with hideous streak and stain" connects malevolence in nature with a fear of women. There is no sign of the natureworshipping pantheism of the Romantics in this poem. Evil in nature is linked to the feminine in Eliot as in Baudelaire. While Les Fleurs du Mal contains several instances of the theme of woman as frightening, it was in his diaries, published posthumously, that Baudelaire commented most crudely on women:

La femme est le contraire du dandy. Donc elle doit faire horreur. La femme a faim et elle veut manger. Soif, et elle veut boire. Elle est en rut et elle veut être foutue. La beau merite! La femme est naturalle, c'est-a-dire abominable. Aussi est-elle toujours vulgaire, c'est-a-dire le contraire du dandy!

(Baudelaire, Euvres Completes 1272)

Woman is the opposite of the dandy. Therefore she inspires horror. Woman is hungry so she must eat; thirsty, so she must drink. She is in heat so she must be fucked. How admirable! Woman is natural, which is to say abominable. (qtd. in Pierrot 123)

Baudelaire's misogyny, which led to a need to maintain a distance from the woman, caused him to stress the importance of a dandy figure opposed to woman through his indifference to or fear of her and resistant to the natural in his artificiality. While Eliot's use of the sophisticated, urbanised dandy-figure, plagued by fastidiousness and trapped in a world of his own making in poems such as 'Portrait of a Lady' and 'The Love Song of J. Alfred Prufrock' (both 1911) was a legacy of Laforgue (Svarny 49), it also owed something to Baudelaire, whose 1863 essay 'Le Peintre de la Vie Moderne' ('The Painter of Modern Life') was one of the significant early works of 
dandyism. ${ }^{2}$ Through the existence of the dandy, especially through the use of irony linked to his situation, Eliot repudiated the assuredness of the lyric speaker of Romantic poetry thus ensuring that his poems were sufficiently depersonalised. The portrayal of the dandy also provided him with an initial apprenticeship in character creation which was an important part of his movement towards drama per se. Baudelaire's misogyny and dandyism are echoed in the poetry of Laforgue who had a more powerful impact on the young Eliot than the writer of Les Fleurs du Mal.

From Laforgue, Eliot learned to create characters that spoke ironically and yet are often puppets in their creator's hands. These characters chiefly existed within drawing rooms or intimate theatres. In this interior world Eliot was able to create very real characters that interacted with each other as opposed to the solitary figure of the late Romantic poet in nature. This move from outdoors to indoors was undoubtedly a reflection of modern existence, besides being a further move away from the neo-Romantics. It involved the use of characters and the world of people as opposed to the neo-Romantic employment of the world of nature. Laforgue's influence is observed in Eliot's presentation of ironic situations where characters posed or acted out roles in opposition to each other to bring out their differences.

Laforgue's use of monologue and dialogue in his poems indicates his own anti-Romantic stance. The landscape of Laforgue's poetry often played a dandy against a desired but also despised female companion. His Pierrot poems focus on a clown figure who, in the case of 'Autre Complainte de Lord Pierrot' ('Another Lament of Lord Pierrot'), is with a female friend. Lord Pierrot ignores the romantic attentions of the woman and takes off on a philosophical tangent in what appears to be an attempt at detachment. The central Laforgian theme of communication (or lack of proper communication) between the sexes is expressed through the “counterpointing of conventional romantic expectations against the dandy's mode of wry, understated disengagement" (Svarny 51). The irony of the moment is most certainly anti-Romantic, as is the use of the first-person pronoun which signifies a persona, a definite character separate from the poet:

Et si ce cri lui part: « Dieu de Dieu! que je t'aime ! » - «Dieu reconnaitra les siens. » Ou piquée au vif :

\footnotetext{
${ }^{2}$ Baudelaire, C. "The Painter of Modern Life." Trans. J. Mayne. The Painter of Modern Life and Other Essays. Ed. J. Mayne. London: Phaidon Press, 1964. 1-40.
} 
- «Mes claviers ont du cœur, tu seras mon seul theme. »

Moi : « Tout est relatif ».

(Laforgue, 'Autre' 391, 11. 5-8)

And if this cry escapes her: "God, O God! How I love you!"

-- "God will recognize his own". Or, stung to the quick:

-- "My keyboards have a soul, you will be my sole theme."

I: “All is relative.” (Laforgue, 'Another' 208, 11. 5-8)

The dandy's indifference to the lady's protestations of love is a prime example of Laforgian irony at work in these lines. Eliot's own 'Conversation Galante' (1909) is based on 'Autre Complainte de Lord Pierrot' (Kenner 17). ${ }^{3}$ While in Laforgue it is mainly the woman who does the talking, in Eliot's poem the male speaker, who is a dandy figure, assumes this task (Svarny 50). However, as in Laforgue, Eliot's dandy adopts a detached intellectual pose which the lady finds difficult to endure. Here, Eliot makes extended use of dialogue between the dandy and the lady as indicated by the inverted commas:

I observe: 'Our sentimental friend the moon!

Or possibly (fantastic, I confess)

It may be Prester John's balloon

Or an old battered lantern hung aloft

To light poor travelers to their distress.'

She then: 'How you digress!' (Complete 33, 11. 1-6)

Through his use of ironic dialogue and the unconventional lunar image Eliot parodies traditional Romantic descriptions of the moon or of moon-related imagery such as those utilised by Shelley in 'The Cloud':

That orbed maiden with white fire laden,

Whom mortals call the moon,

Glides glimmering o'er my fleece-like floor

\footnotetext{
${ }^{3}$ This date is provided by Grover Smith (9).
} 
By the midnight breezes strewn [...]

(Shelley 462, 11. 45-48)

Eliot's identification of the moon with a balloon belonging to Prester John, a mythological king who was said to keep the fires of Christianity burning in the Orient in Medieval times, is no doubt a parody of standard presentations of the moon by neo-Romantic writers. ${ }^{4}$ It is very different from the juvenile employment of lunar imagery by Georgian poets such as Walter de la Mare who provides us with this rather banal depiction in 'Full Moon' (1913):

One night as Dick lay half asleep, Into his drowsy eyes

A great still light began to creep

From out the silent skies.

It was the lovely moon's, for when

He raised his dreamy head,

Her surge of silver filled the pane

And streamed across his bed (de la Mare 149, 11. 1-8)

Eliot's moon is more in line with that employed by Hulme in 'Above the Dock', a well-known Imagist poem:

Above the quiet dock in midnight,

Tangled in the tall mast's corded height, Hangs the moon. What seemed so far away

Is but a child's balloon, forgotten after play. (Hulme 266, 11. 1-4)

Both Hulme and Eliot used the idea of a balloon to depict the moon, something very different from typical Romantic and Georgian portrayals of the moon. It is unlikely that Eliot was aware of Hulme's poetry at the time but it is intriguing that the two writers use similar imagery.

\footnotetext{
${ }^{4}$ See Jubber, N. The Prester Quest. London: Doubleday, 2005 for a witty account of a modern-day search for Prester John. On pages 7 and 8 of his book, Jubber gives us an account of the origin of the Prester John myth.
} 
Part of the irony of the scene in 'Conversation Galante' emerges due to the dual nature of the speaker-character. ${ }^{5}$ The male figure appears bored with the cues he receives from the woman which seem to make him carry on with his "inane" (Complete 33, 1. 12) speech. We no longer have the gentle, lyric persona of 'A Lyric: If Time and Space'. In its place we find a dramatic presentation of the self: an egotistical dandy engrossed in his philosophical world. Eliot employed the mask of the dandy after being influenced by Laforgue's own Pierrot figures. This facade allowed him to protect his identity and "distance himself from his fellow human beings" (Seymour-Jones 43). Laforgue's clown was a dandy, and it was the element of dandyism that Eliot clung onto as the male figure in his poetry projected an air of indifference to the woman's needs. The woman in her protestations of love appears to be a symbol of Romanticism while the male, who ignores her and thus rejects her, parallels Eliot's need to react against Romanticism at this time. The conflicting desires of the two characters bring to the fore a certain dramatic quality in the poem based on the tension and dialogue present in it.

The creation or existence of the dandy in the Laforgian style involved a splitting of the self into the participant and observer (Svarny 48). ${ }^{6}$ Simultaneously, there was a breaking up of the self into male and female. The splitting at both levels in Eliot's poetry gave rise to dialogue which brought the poetry closer to drama. The split selves in his poetry could also be linked to the androgyny which became "fashionable in Bloomsbury in the 1920s", and was part of the revolt "against middle-class morality by the self-consciously decadent" (Seymour-Jones 309). This decadence ensures the splitting of the androgynous self into male and female in Eliot's poems and gives rise to different voices and to drama. The presence of at least two voices that emerged from the split allowed for the occurrence of dialogue, thus making the work more dramatic.

Geary believes that Eliot's employment of the Laforgian ironic voice in 'Nocturne' (1909), "whereby the protagonist is split into actor and observer", allows for "a play of distances" enabling us to view the poem as a restaging of Romeo and

\footnotetext{
${ }^{5}$ Sigg also points to the splitting of the narrator in 'Conversation Galante': "Here [in 'Conversation Galante'] and in Eliot's juvenilia ('On a Portrait', 'Nocturne', 'Humouresque (after J. Laforgue)', and 'Spleen'), Laforgue helped Eliot experiment with ironic, multiperspective commentary by a narrator upon other characters, by characters upon themselves, and by the reader upon the poem" (95).

${ }^{6}$ Grover Smith points out in Eliot's early poems "Splitting or 'doubling' himself into languid sufferer and satiric commentator, he wrote poems deriding in one passage the tenderness of another" (5).
} 
Juliet as Symbolist drama (23). The speaker seems to be either a playwright or director. Eliot breaks from conventions of love in Shakespeare's Romeo and Juliet, delighting instead in a farcical presentation of a mock tragic ending to the lovers' 'performance'. This is one of the first Eliot poems in which we see characters interact with one another while presented on what seems to be a stage. 'Nocturne' also provides an example of the early use by Eliot of a dandy, a character which, as we have seen, was borrowed from Laforgue and later used to great effect in 'The Love Song of J. Alfred Prufrock' and 'Portrait of a Lady'. In the poem Eliot models his dandy figure on the character of Romeo:

Romeo, grand sérieux, to importune

Guitar and hat in hand, beside the gate

With Juliet, in the usual debate

Of love, beneath a bored but courteous moon [...]

(Complete 601, 11.1-4)

Here the speaker uses the French words "grand sérieux" to satirize the romantic scene and makes fun of the traditional image of the lover serenading his beloved with his "guitar and hat in hand". The moon, usually associated with lovers, is personified. The boredom and courteousness attributed to the stage moon could be seen as the reactions (or lack of them) of the speaker and the metaphorical audience to the performance. The actions in 'Nocturne' do not go according to script, at least not in the Shakespearean manner. The speaker decides to indulge himself as dramatist and introduces a servant to kill Juliet while the conversation between the lovers becomes increasingly banal (see Geary 24):

out of pity for their fate

Behind the wall I have some servant wait,

Stab, and the lady sinks into a swoon. (Complete 601, 11. 6-8)

As in his previous poems the relationship between Eliot's lovers is insipid. Here Eliot displays the influence of drama on his early writings as he uses the Shakespearean play and the excessive blood-letting of the Elizabethan and Jacobean stage in his poem. However, while doing so, he also parodies the Elizabethan stage. 
The end arrives with a theatrical stabbing introducing the theme of murder and the idea of melodrama in his work. The murder motif would recur in Eliot's plays, most importantly in Sweeney Agonistes which, with its parallels to the demonic barber of Fleet Street, Sweeney Todd, also had connections to Victorian melodrama (see Mack 206). 'Nocturne' contains the dramatic element of movement in it as we can imagine a servant waiting behind a wall, a stabbing and the lady sinking "into a swoon" (Complete 601, 1. 8). In this sense it resembles the later 'Sweeney among the Nightingales' where Sweeney may well suffer a fate similar to Eliot's Juliet. The link between 'Nocturne' and the Sweeney poems may go beyond this. While Stillman believes that 'Sweeney among the Nightingales' possesses similarities to Eliot's marionette poems 'Humouresque' (1909) and 'Convictions' (1910), poems that I shall discuss a bit later, the same may be true of other Eliot poems including 'Nocturne' (Stillman 126). The characters of these poems seem to have similarities to marionettes that have no powers of their own and are controlled by the speakerdirector who is a puppeteer. This would be in keeping with Eliot's interest in puppet plays as part of his theory of drama discussed in chapter one.

The tongue-in-cheek presentation of human relationships in 'Nocturne' is essentially Laforgian in nature. Instead of dying flowers we now have a bored moon. Eliot had begun to dramatize his ideas in poetry, to use objects and actions to convey emotions. The presence of a speaker who watches the scene and is perhaps even the dramatist or director or puppeteer provides us with a special perspective from which to observe the action and makes us feel like an audience with an insider's view, perhaps even like viewers watching a movie with the director's comments playing.

The speaker in 'La Figlia Che Piange' ('The Girl Who Weeps') (1911) seems to fulfil the role of a director in a rehearsal who provides locations for the characters to place themselves on stage, dictates the manner in which they should stand and what gestures or actions they should perform (G. Smith 27; Sigg 96). In the first stanza, the speaker instructs the female lead:

Stand on the highest pavement of the stair -

Lean on a garden urn -

Weave, weave the sunlight in your hair -

Clasp your flowers to you with a pained surprise - 
Fling them to the ground and turn

With a fugitive resentment in your eyes [...] (Complete 34, 11. 1-6)

One can easily imagine the scene playing itself out on a stage. The explicit action here, the woman clasping the flowers and her flinging of the same flowers a moment later, tends to make the poem more dramatic. The speaker is also observer and presents us with a feeling of someone watching the scene. In the second stanza, he attempts to make sense of the break-up while beginning to identify with the male lover figure that has walked away from the relationship. Thus the speaker plays both the director and male lover in a case of doubling (G. Smith 27):

So I would have had him leave,

So I would have had her stand and grieve,

So he would have left

As the soul leaves the body torn and bruised,

As the mind deserts the body it has used.

I should find

Some way incomparably light and deft,

Some way we both should understand,

Simple and faithless as a smile and a shake of the hand

(Complete 34, 11. 8-16)

By means of this dédoublement the speaker is "at once the actor and the consciousness of his action" (Moody 38). As Bush puts it, he "protects his ironic stance by splitting himself up into a participant lover ('he') and 'I', the detached observer who is now entirely outside the encounter" (13). The speaker sympathizes with and understands the characters more than in 'Nocturne', because, unlike the speaker of 'Nocturne', he is, more directly, part of the action both creating, as a director, and, as an actor, being involved in the parting scene between the lovers (see G. Smith 27).

While his early imitations of Laforgue included either dialogue between the figures or a description of actions from both an internal and external perspective, Eliot soon switched to dramatic monologue mode where he developed the ability to make his poetic figures speak in a fashion which came close to being dramatic. 


\subsection{Use of the dramatic monologue}

From his early poetry onward, Eliot's doctrine of impersonality in art "inclined him to the use of personae and incipiently dramatic situations" (Jones 26). This usage became quite explicit in his dramatic monologues. The dramatic monologue as a form presented "the imagined speech of a 'character' or a 'persona', in a dramatic situation" (Jain 35) and was one of the most important forms of Eliot's poetry (Langbaum 77). Eliot's primary influences in the use of the form would be Laforgue and Browning but he was also influenced by other poets in this regard. Eliot admitted that he had read several British poets of the late 1890s who employed a "colloquial idiom" (Saltire Rev., 1957, cited in Inventions 397). These included Scottish poet John Davidson whose poem 'Thirty Bob a Week' (1894) Eliot praised as the only one in which he "freed himself completely from the poetic diction of English verse of his time" (Eliot, 'Preface'). Clearly, Eliot admired Davidson as he was looking for a colloquial diction to portray the dramatic changes of his time:

For like a mole I journey in the dark,

A-travelling along the underground

From my Pillar'd Halls and broad Suburbean Park,

To come the daily dull official round;

And come home at night with my pipe all alight,

A-scheming how to count ten bob a pound

(Davidson 72, 11. 13-18)

This description of a journey on the London Underground is obviously different from the landscape that the Romantics presented given that the Underground did not exist before 1863 (Womar 41). It creates a sense similar to that in the last section of part one of The Waste Land where the speaker describes a crowd flowing over London Bridge who have been undone by a death brought on by their "daily dull official round" (Complete 62, 11. 60-63). However, while Eliot's poem describes the life of the worker only when he enters the inner city, Davidson's work also introduces the suburban existence of the urban traveller. Davidson's use of the dramatic monologue 
brings character to the forefront in this poem, something which Eliot found compelling (Ackroyd 33). Eliot would use the same form to portray his own ideas about the city and to present modern-day characters in poems like 'The Love Song of J. Alfred Prufrock'.

The dramatic monologue was developed almost simultaneously but separately by Browning and Tennyson and became a reaction of the Victorians against the lyric speaker of the Romantics (Sinfield 64; Byron 3). The use of the dramatic monologue involved a deliberate attempt to avoid self-expression and employed a speaker who was different from the figure of the poet (Howe 23; Byron 11). This is clarified by Glennis Byron's claims that the manner in which Eliot created speakers in his dramatic monologues, borrowing lines from other writers such as Dante and Shakespeare, firmly established the speaker as a literary construct as opposed to the lyric speaker of Romanticism who was directly associated with the poet himself (114). Additionally, the dramatic monologue employed a language which was colloquial and helped stress dramatic elements in the lyric.

Sessions defines the perfect dramatic monologue as "that literary form which has the definite characteristics of speaker, audience, occasion, revelation of character, interplay between speaker and audience, dramatic action, and action that takes place in the present" (508). While not every dramatic monologue possesses all these qualities, we can safely say that many of these qualities are present in Eliot's works and that their presence allowed him to introduce more of the dramatic into his poetry.

An abrupt beginning created a sense of occasion necessary for the dramatic monologue as a form (Curry 9). For instance, the famous opening lines of Browning's 'My Last Duchess' have an air of suddenness and theatricality about them: "There's my last Duchess painted on the wall, / Looking as if she were alive [...]" $(101,11.1-2)$. Eliot reproduced such a sense of immediacy at the start of 'The Love Song of J. Alfred Prufrock':

Let us go then, you and I,

When the evening is spread out against the sky

Like a patient etherised upon a table [...] (Complete 13, 11. 1-3). 
One of the traditional elements of the dramatic monologue is the presence of an auditor or audience (Abrams, Glossary 48; Byron 20). As we have observed in the introduction, the sense of an audience is an important dramatic element which serves to bring the dramatic monologue form closer to drama. While the 'you' in the opening line of 'The Love Song of J. Alfred Prufrock' has been taken to be an auditor (Byron 114), it has also been read as representing a differentiation between Prufrock's "thinking, sensitive character" or inner self and "his outward self" (G. Smith 16; Christ 221). In the latter interpretation, the poem need not be seen as a traditional example of the dramatic monologue as the auditor or internal audience and the speaker are one and the same person who is more closely linked to the poet than in traditional dramatic monologue. This tends to increase the lyrical quality of the monologue while perhaps reducing some of its dramatic quality. The result is symptomatic of the fact that Eliot had not yet crossed over into drama completely and that he was still experimenting with how much of the dramatic he could introduce into his poetry without actually abandoning the poetic form altogether as he finally did in Sweeney Agonistes.

For Mayer, Eliot's monologues are psychic utterances, what he calls psychologues or innerlogues: the presentation of thoughts and feelings, rather than speech per se, "a conversation of voices within" (12). At one level the "psychologue' is not dramatic as it involves an internalization of thought and emotion. However, at another level "the conversation of voices within" a 'psychologue' provides "an extraordinary sense of excitement" (Mayer 12,14). This sense of excitement is observed in 'The Love Song of J. Alfred Prufrock' and it stems from the dramatic effect created by the shift from one voice to the next within a single consciousness. The "conversation of voices within" is evident in the poem when the speaker muses: “And indeed there will be time / To wonder, 'Do I dare?' and, 'Do I dare?"” (Complete 14, 11. 37-38). The fact that the speaker asks the same question twice points to the doubling up of his personality. While the two 'do I dare' questions look similar they may differ in that the answers connected to them (which are not stated) are most probably different. The voices that are in conversation within the same personality succeed in creating the sense of the presence of an external dialogue which increases the dramatic nature of the piece even while retaining its lyrical quality. 
In 'Portrait of a Lady' (1911) Eliot employs the dandy speaker in the dramatic monologue form. This speaker maintains a generally detached air in the face of a verbal and visual barrage from the lady. In part one, he appears to address the lady directly:

Among the smoke and fog of a December afternoon

You have the scene arrange itself - as it will seem to do -

With 'I have saved this afternoon for you';

And four wax candles in the darkened room,

Four rings of light upon the ceiling overhead,

An atmosphere of Juliet's tomb

Prepared for all the things to be said, or left unsaid.

(Complete 18, 1, 11. 1-7)

Like a director or set designer, the lady arranges the "scene" for the performance that is to come. This is in addition to her role as an actor. There is a conflict here between her desire to set the scene and the male speaker's need to control this moment too. His resentment about her taking over the directorial role emerges through his sarcastic presentation of her, causing him to slip into internal monologue mode after she carries on about Chopin. The use of punctuation marks, specifically inverted commas here, allows us to make out where the lady is talking. The shift from the outer dialogue of the lady to the inner observations of the man is actually a movement from the dramatic to a more lyrical state:

'So intimate, this Chopin, that I think his soul

Should be resurrected only among friends

Some two or three, who will not touch the bloom

That is rubbed and questioned in the concert room.'

- And so the conversation slips

Among vellieties and carefully caught regrets

(Complete 18, 1, 11.10-15)

The auditor in a traditional dramatic monologue is usually silent and we learn about his or her presence from cues provided by the speaker (Abrams, Glossary 48; Byron 
20). For example, in Browning's 'My Last Duchess' the duke addresses his listener, thus making us aware of the presence of another person: "Will't please you sit and look at her?" (101, 1. 5) By contrast, the lady, who is supposed to be the auditor in 'Portrait of a Lady', is extremely garrulous and provides a dramatic voice in the poem when she talks to the dandy-speaker. This has led Kenner to claim that "the great successes of this one overtly dramatic Eliot poem coincide with the Lady's speeches" (23).

In fact, it is questionable who the actual auditor of the poem is, given that the lady speaks so often and dominates external proceedings. Through the poem, Eliot questions the very notion of the auditor or audience itself. The lady's speech becomes a musical performance in the theatre accompanied as it is by violins and cornets. As Giannone says, her "quoted remarks do add a dramatic dimension" to the poem and brings it "close to dialogue and drama" (131). However, it is not just her remarks that matter but the responses or imagined responses of her dandy companion which adds to the sense of dialogue:

'You do not know how much they mean to me, my friends, And how, how rare and strange it is, to find

In a life composed so much, so much of odds and ends,

(For indeed I do not love it...you knew? you are not blind!

How keen you are!)

To find a friend who has these qualities $[\ldots]$

(Complete 18, 1, 11. 19-24)

There seems to be an outer performance meant for an audience in terms of the woman's words that are not in parenthesis but in inverted commas. The words in parenthesis seem like an aside in theatre but they are actually directed to her internal audience, the protagonist of the poem. In the midst of what seems to be an oftpractised speech, the lady breaks off in the parenthesis to acknowledge her listener, her male companion who has perhaps made a remark or some gesture to her that she interprets as a sign of acknowledgement. On the other hand, it is also possible that the male has made no statement or gesture and the woman is just carrying on as she is wont to do. The hint of interaction between the lady and her listener adds to the dramatic possibilities of the scene since it gives us scope to imagine what the man 
has said or done that has made her react in such a fashion even if her speech completely drowns out his voice. However, in the absence of his words or actions, the lyrical aspect of the moment is also maintained.

In part two the speaker drops the charade of speaking to the lady and directly addresses the reader or another audience altogether. The lady is now spoken of as in the third person rather than addressed directly as "you":

Now that lilacs are in bloom

She has a bowl of lilacs in her room

And twists one in her fingers while she talks.

(Complete 19, 2, 11. 1-3)

As the lady begins to become more talkative the male speaker starts to withdraw. In his diffidence and silence he is opposed to her garrulousness and symbolically threatening behaviour, here the twisting of lilac stalks. In fact, Grover Smith points to an affinity between what he calls "the Laforguian contrivance of one-sided dialogue" in 'Portrait of a Lady' and something similar in The Waste Land which we can assume refers to the one-sided exchange between the lady and her partner in part two of the latter poem, 'A Game of Chess' (10). Eliot's treatment of the 'speaker''audience' relationship not only introduces a strong dramatic element in the poem, but he goes a step further in challenging the traditionally uni-directional nature of that relationship. In other words, realistic theatre - which Eliot sought to repudiate saw the audience sit passively and receive the action of the speaker; here, the audience is sometimes actor, and the actor sometimes audience. The effect is to create a dramatic scenario of actor-audience that is closer to the communal nature of ritual as discussed in chapter one.

The male speaker's internal antagonism towards the lady in 'Portrait of a Lady' is contrasted by his dapper exterior as he feigns interest while actually being tormented by her presence, speech and deeds. The poem unravels within two distinct spaces - the internal space of the speaker's mind and the external space, where we hear the lady talk most of the time; as Sigg points out "her reticent guest's evaluative monologue interior counterpoints the lady's diffuse, melancholy speeches" (97). This is an extension of what Sigg calls Eliot's "homo duplex paradigm", the doubling of roles of the dandy as both observer and speaker in earlier poems such as 'Nocturne' 
has here changed to having the lady as speaker and the dandy as observer (97). By juxtaposing the external sound of the lady's words against the internal description of what the speaker sees or feels Eliot attains a kind of irony and doubling which lends a dialogue-like sense to the lines. Part of the irony arises from both events happening simultaneously since one comments on the other. For example, while the woman talks about the cruelty of life and youth, her young companion observes her and indifferently sips his tea:

'Ah my friend, you do not know, you do not know

What life is, you who hold it in your hands';

(Slowly twisting the lilac stalks)

'You let it flow from you, you let it flow,

And youth is cruel, and has no remorse

And smiles at situations which it cannot see.'

I smile, of course,

And go on drinking tea. (Complete 19, 2, 11. 4-11)

By describing for us the woman's actions and giving us her words while watching her all the time through the male persona, Eliot allows the reader to slip into the role of the man, to become, as it were, a kind of audience and participant watching the lady, just as he does. The lady's actions of twisting the lilac stalks add to the dramatic tension of the moment. The speaker, who cannot bear the lady's loquacious performance, breaks down in part three into an internal performance of his own:

And I must borrow every changing shape

To find expression ... dance, dance

Like a dancing bear,

Cry like a parrot, chatter like an ape. (Complete 21, 3, 11. 26-29)

Significantly, even at this moment of disintegration the shapes are borrowed and the animals mentioned are trained ones pointing to the artificiality and practised, almost rehearsed nature of this internal performance (see Ferrall 75). The use of dance as an idea and image here is interesting considering how important Eliot felt dance was to modern verse drama (Selected 46). Also, the portrayal of the speaker as a dancing bear - an animal which has been used for street and circus performances throughout 
the world - makes the reader aware that he is watching many kinds of performance in the poem.

'Portrait of a Lady' displays similarities with Eliot's prose-poem 'Hysteria' (1915), where the dandy-speaker is threatened by the presence of a dominating woman. The title 'Hysteria' is interesting considering at the time of its usage, the word incorrectly referred to a nervous disorder in women which was thought to be the result of a disturbance of the uterus, with which Eliot's first wife, Vivienne, was probably diagnosed (Seymour-Jones 17). Today, the medical implications of the term as it existed in the 1910s have long since been debunked.

The prose poem was seen as a subversive form, first popularized by Baudelaire and part of the Decadent movement in nineteenth century France (Murphy 4). It allows Eliot to present snatches of dialogue and narrative in a more colloquial tone, providing the speaker with a conversational tone and implying that a wider audience is listening in or watching the action. There is one half of a dialogue in the poem when the waiter wants to know "if the lady and gentleman wish to take their tea in the garden" (Complete 32) However the rest of the poem appears to be the internal monologue of the woman's male companion.

This male speaker is distracted by the woman's heaving breasts and becomes increasingly irritated by her physicality. We see here more clearly than elsewhere the revulsion felt by the self-loving dandy when faced with the physical reality of the perceived femme fatale. He must suppress the woman's sexuality in order for his mind to be at rest: "I decided that if the shaking of her breasts could be stopped, some of the fragments of the afternoon might be collected [...]" (Complete 32).

This poem again reminds us of a possible dédoublement as the speaker is both observer and participant. The only words spoken out loud are those uttered by the seemingly anxious waiter. The question to be asked here is who is the actual hysteric? The sense that the one suffering from hysteria is actually the male speaker allows us to enter his thought processes and see the scene played out in front of us. However, the fact that the speaker has thoughts, which are internal, makes the moment more lyrical, rather than dramatic. The internalization of thought and action ensures that the poem, despite possessing some potential for dialogue, does not quite assume dramatic qualities.

Seymour-Jones claims there is a dédoublement at work in Eliot's French poem 'Dans le Restaurant' ('In the Restaurant', 1917) where the garrulous waiter 
relates a near-sexual childhood encounter to the disgusted customer-speaker. She points us towards an actual incident in Eliot's own life when, as a little boy, he may have had an encounter with a young girl, Dorothy (Seymour-Jones 39). ${ }^{7}$ She believes that the speaker is protagonist and waiter at the same time, both of whom have had shared experiences (Seymour-Jones 40). Eliot's use of a foreign language points to a need to distance himself from the speaker and waiter given the possibility of the incident mentioned in the poem possessing echoes from the poet's past. There is a considerable amount of dialogue in the poem as a result of this dédoublement:

'Les saules trempés, et des bourgeons sur les ronces -

C'est là, dans une averse, qu'on s'abrite.

J'avais sept ans, elle était plus petite.

Elle était toute mouillée, je lui ai donné des primevères.

(Complete 51, 1l. 8-11)

'Drenched willows, buds on the brambles -

It was there, in a shower, that we took shelter.

I was seven; she was smaller.

She was soaked to her skin. I gave her primroses.'

(Trans. in Raine 180, 11. 8-11)

While inverted commas are used to present to us the outer voice of the waiter, the inner observations of the customer are revealed through the use of parenthesis. The presentation of the customer's thoughts as internal monologue parallels similar usage in 'Portrait of a Lady'. However, the conflict between the waiter's speech and the customer's inner ramblings, which increases the tension and the sense of dédoublement, brings the moment close to being dramatic. It also, paradoxically, highlights the humour in the piece:

(Bavard, baveux, à la croupe arrondie, Je te prie, au moins, ne bave pas dans la soupe).

(Complete 51, 11. 6-7)

\footnotetext{
${ }^{7}$ This encounter is related in a letter of Eliot to John Hayward dated 27 December 1939, now part of the John Hayward Bequest, King's College, Cambridge (Seymour-Jones 601, n 23).
} 
(Gossip, dribbler, with a rounded rump,

I beg you, at least, not to gob in my soup)

(Trans. in Raine 180, 11. 6-7)

At the end of the poem Eliot finishes with the original Phlebas passage which, when translated to English, became part four of The Waste Land. This goes to show that he was already mixing monologue, dialogue and pure lyric before he moved to The Waste Land.

Eliot returned to a purer use of the dramatic monologue form in 'The Love Song of St. Sebastian' (1914). The poem was the result of his viewing of three paintings of St. Sebastian as he travelled through the art galleries of Italy and Belgium in 1911 and 1914 respectively (Letters 1: 41). The speaker imagines himself as the Christian martyr, St. Sebastian, who was tortured by having arrows shot at him. He fantasizes about indulging in mortification, not for the sake of God, but, almost blasphemously, for a woman who assumes or is made to assume the dual role of the female beloved and St. Irene, the lady who rescued St. Sebastian after he was shot on the orders of the Roman emperor. ${ }^{8}$ Thus the speaker provides a modernised version of a Christian myth through this poem, hinting at a possible sadomasochistic relationship with the woman he sees as both saint-rescuer and the feared object of desire. Through his monologue he appears to be talking to his beloved about an action which has not yet occurred but which he is planning to carry out:

I would come in a shirt of hair

I would come with a lamp in the night

And sit at the foot of your stair;

I would flog myself until I bled [...] (Inventions 78, 11. 1-4)

The speaker here is either in an internal monologue or a dramatic soliloquy. The sense of soliloquy is especially strengthened by the revelation that he intends to

\footnotetext{
${ }^{8}$ See Butler, A. The lives of the fathers, martyrs, and other principal saints: compiled from original monuments, and other authentic records. Dublin, 1779-80. Vol. 1 of 12, 312, printed by John Exshaw, for John Morris, 1779-80. Eighteenth Century Collections Online, accessed May 25, 2010 at: http://galenet.galegroup.com.helicon.vuw.ac.nz/servlet/ECCO?dd=0\&locID=vuw\&d1=1236300101\& srchtp=a\&c=1\&SU=0LRF\&df=f\&d2=311\&docNum=CW3323461563\&h2=1\&vrsn=1.0\&af=BN\&d6 $=311 \& \mathrm{~d} 3=311 \& \mathrm{ste}=10 \& \mathrm{stp}=$ Author $\& \mathrm{~d} 4=0.33 \& \mathrm{n}=10 \& \mathrm{~d} 5=\mathrm{d} 6 \& \mathrm{ae}=\mathrm{N} 047526$
} 
strangle his beloved and by the words taken verbatim from Othello's soliloquy before he kills Desdemona: "And then put out the light" (Inventions 78, 1. 10, Othello 5.2.1, 1. 7) revealing the influence of Elizabethan drama on Eliot (Miller 246). The reference to a possible strangulation is thus not only an imitation of Browning's dramatic monologue 'Porphyria's Lover', where the deranged lover describes killing his beloved by using her own hair to strangle her (123), but a continuation of the Othello-Desdemona theme:

You would love me because I should have strangled you

And because of my infamy;

And I should love you the more because I had mangled you

And because you were no longer beautiful

To anyone but me. (Inventions 78, 11. 34-38)

What is compelling here is that unlike Othello, who is racked by jealousy, and Porphyria's lover, who is patently insane, Eliot's speaker has no apparent reason for wanting to kill his beloved. It may seem therefore that the reason is contrived or that it arises from a fear or loathing of the beloved. In echoing the dramatic soliloquy of the Elizabethan stage, introducing the theme of murder and focusing on the motives of the persona or character, 'The Love Song of St. Sebastian' displays very interesting theatrical elements which point to the dramatic nature of the poem.

Eliot brought to his dramatic monologues the ironic self-detachment that was typical of Laforgue and which fore-grounded the dramatic. However, his use of interior monologue in these poems allowed for retention of their lyric sense even as it suggested an increase in the dialogue-like quality through juxtaposition of internal and external voices and a kind of dédoublement. This quality was often introduced through the unconventional presence of a garrulous auditor whose words were juxtaposed against the inner ramblings of the speaker as in 'Portrait of a Lady'. Eliot's dramatic monologues were far from conventional. They allowed for a free interplay of lyric and dramatic elements and further complicated the ambiguous nature of the form. 


\subsection{Spotlight on the stage: Vaudeville and marionettes}

Eliot's heavy reliance on theatrical imagery and themes in some of his poems of this time produces a strong sense that the reader becomes a kind of metaphorical audience for his poetry. We have already observed this in such poems as 'Nocturne' and 'Conversation Galante' and will come across more such examples in his poems written under the influence of vaudeville and the marionette theatre.

Laforgue's work had impressed on Eliot the need to use elements of performance and music in his poetry. After reading Laforgue, Eliot used lines and images from vaudeville, ragtime and minstrelsy in an avant-garde, pastiche style of writing. Eliot's preoccupation with music and the stage can be observed in the fourpart 'Suite Clownesque' (1910), where he employed elements of harlequinade and vaudeville. Eliot also followed the Laforgian process here of using a clown to comment on the ironies of life in his poetry and the word 'clownesque' was taken from Laforgue's suite Pierrots (1886) (Inventions 162). There is, in Eliot's poem, a description of the audience as well which heightens the dramatic nature of the piece. A world of theatre swirls around us and we are caught in its current, constantly moving with it:

Here's the comedian again

With broad dogmatic vest, and nose

Nose that interrogates the stars

Impressive, sceptic, scarlet nose

The most expressive, real of men,

A jellyfish impertinent,

A jellyfish without repose.

Leaning across the orchestra

Just while he ponders, legs apart,

His belly sparkling and immense:

It's all philosophy and art.

Nose that interrogates the stars

Interrogates the audience

Who still continue in suspense 
Who are so many entities

Inside a ring of lights! (Inventions 32, 1, 11. 5-20)

The prominent nose of the comedian reminds us of Rostand's Cyrano de Bergerac. As readers we can actually begin to imagine this theatrical character wearing his "broad dogmatic vest" and "leaning across the orchestra", ready to begin the show. The audience themselves are part of the performance in Eliot's poem, much like the music-hall audience that Eliot described in 'Marie Lloyd', and the suspense that they feel is linked to the anticipation associated with the presentation. The sense of performance inherent in words like "role" (Inventions 32, 1, 1. 24) and the presence of an orchestra, something which Eliot was to later use in his pageant play The Rock, heighten the dramatic intensity of the poem.

In 'Suite Clownesque' Eliot describes the opening of a vaudeville show with the comedian as a Master of Ceremonies. After the comedian's grand entry onto the scene there is a series of acts beginning with a line of seven chorus girls a common feature of many vaudeville acts:

Each with a skirt just down to the ancle [sic]

Everybody is under age

Three on a side and one in the centre

(Who would venture to be a dissenter)

Hello people!

People, hello! (Inventions 34, 2, 11. 1-6)

We hear the chorus girls welcoming the audience. Indeed, the girls appear to sing a song telling the audience what they are doing. As readers we can not only hear the girls speaking but we can also imagine them acting or indulging in movement on the stage such as going for a walk, running, and boarding a stage streetcar:

We've started out to take a walk

Each in a simple hat and gown,

Seven little girls run away from school

Now for a peek about the town.

Here's a street car - let's jump in 
Oh see the soldiers - let's descend.

When you're out on for an afternoon

Find somebody with money to spend. (Inventions 34, 2, 11. 9-16)

There is a connection between the reference to the "seven little girls" of Eliot's chorus and the song "Three little maids from school" in Gilbert and Sullivan's opera The Mikado (1885) which was popular on the London stage in the late nineteenthcentury (Inventions 168). Eliot's chorus girls share the same enthusiasm for a day out as the three little maids and the chorus of girls from the opera:

THE THREE: Three little maids from school are we,

Pert as a school-girl well can be,

Filled to the brim with girlish glee,

Three little maids from school!

YUM: $\quad$ Everything is a source of fun. [Chuckle]

PEEP: $\quad$ Nobody's safe, for we care for none! [Chuckle]

PITTI.: $\quad$ Life is a joke that's just begun! [Chuckle]

THE THREE: Three little maids from school! (Gilbert 377)

However, while Gilbert and Sullivan locate their "little maids" in a relatively childlike and innocent situation on stage, Eliot places his 'girls' in the unsettling adult context of a vaudeville chorus where they would be seen as performers meant to titillate a largely male audience. The speaker's revelation that the girls in Eliot's poem are underage and the description of their flirtations with the soldiers makes the lines more than a bit dubious in nature and leads to an underlying tension in the poem.

We are extremely conscious that everything that happens in the poem takes place on the stage, specifically the vaudevillian stage, and involves an interaction between the performers, and between the performers and the audience. Eliot, through the chorus, refers to the nature of vaudeville as a series of disconnected acts:

But we're perplexed.

Hello people!

Yes indeed we're fearfully vexed; 
People, hello!

In trying to construe this text:

'Where shall we go to next?'” (Inventions 34, 2, 11. 17-22)

Even a stage direction is given (Schuchard 81). ${ }^{9}$ Eliot provides an instruction for a sound effect in the middle of his work as if he meant the poem to be performed. This is almost like a playwright providing instructions for sound effects in his script: "Here let a clownesque be sounded / on the sandboard and bones" (Inventions 35, 3, 11. 13-14). These lines introduce a minstrel element into the poem since the bones were a set of instruments used by one of the players in the American minstrel show who was also called Bones, a character we find in Sweeney Agonistes (Complete 122-23). 'Suite Clownesque' provides a complete theatre, which includes song:

If you're walking up Broadway,

Under the light of the silvery moon,

You may find me

All the girls behind me [...] (Inventions 35, 3, 11. 6-9)

Eliot borrowed some of these lines from the 1909 jazz-vaudeville song 'By the Light of the Silvery Moon' which formed part of Gus Edward's vaudeville sketch, School Boys and Girls (Chinitz, T. S. Eliot 33; Eliot, Inventions 171). In fact the elements of stage performance present in the song itself are quite striking, blending music, drama, dance and poetry in a manner paralleling Eliot's search for a performance aesthetic. The song's opening lines provide us directions about the setting, lighting and sound for the tryst between the lovers:

Place: park, scene: dark,

Silv'ry moon is shining thru' the trees

Cast: two, me, you,

Sound of kisses floating on the breeze. (G. Edwards 3-4)

\footnotetext{
${ }^{9}$ Eliot actually included separate stage directions for his 'Columbo and Bolo verses' as well at the end of these poems showing that he sometimes thought like a dramatist while writing verse. These lines read: "Flourish. Skirmishes and alarums. Cries without. Exeunt the king and queen severally" (Inventions 319).

${ }^{10}$ See chapter four for a more detailed description of minstrelsy and a minstrel show.
} 
It seems no accident that Eliot would refer to this song in his poem as he presents his clown surrounded by chorus girls on stage. Eliot was fond of crooning (Chinitz, T.S. Eliot 32) and sang 'Under the Bamboo Tree', a song which he had used in Sweeney Agonistes, at a party celebrating his Nobel Prize victory in 1948 (Ackroyd 290). St. Louis, where Eliot was born and spent his childhood, was the heart of ragtime music in America in the first decade of the twentieth century. Later, when Eliot left St. Louis to study in Boston in 1904, vaudeville was very much on the Boston scene making Eliot's use of it, in his poetry, extremely contemporaneous.

Schuchard encapsulates the dramatic effect of 'Suite Clownesque' when he points out, "The masked poet has played the clown, directed the play, and conducted the suite with his mad poetics and mock-heroics" (81-82). Like harlequinade, which arose when nineteenth-century British theatre met Renaissance Italian Commedia dell arte, Eliot's poem comprises both a clown and Columbine, a beautiful woman. The final section of 'Suite Clownesque' includes a playing out of the traditional story of harlequinade where the hero (Harlequin) runs away with Columbine:

The hero captures the Columbine

The audience rises hat in hand

And disdains

To watch the final saraband

The discovered masquerades

And the cigarettes and compliments [...] (Inventions 38, 4, 11. 5-10)

Of interest here is the sense of action conveyed by the scene presenting Harlequin's winning of Columbine and the reaction of the audience as it prepares to leave "hat in hand". Besides the harlequinade there is also a saraband, which is a Spanish dance (Inventions 38, 4, 1. 8) but, by now, the audience have lost all patience and are set to leave. The entire spectacle is brought to an end by the reappearance of the comedian who is now reduced to the tools of his trade, part of his costume (the vest) and his artificial nose:

It's the comedian again

Explodes in laughter, spreads his toes 
(The most expressive, real of men)

Concentrated into vest and nose. (Inventions 38, 4, 11. 13-16)

The line "(The most expressive, real of men)" points ironically to the artificiality of the role that the comedian plays in the vaudeville setup. While seeming to be the central figure in control of the show, he is himself controlled and confined by his role and must do the thing required of a clown, laugh and spread his toes, within the theatrical trappings of his vest and false nose.

Eliot's interest in art as performance for an audience continued to display itself in 'The Smoke that Gathers Blue and Sinks' (1911) where the setting shifts from the vaudeville theatre of 'Suite Clownesque' to the interior of a ragtime or jazz club in the early part of the twentieth century. The description of the cigar smoke and after-dinner drinks sets the scene for us as very different from that of 'Suite Clownesque':

The smoke that gathers blue and sinks

The torpid smoke of rich cigars

The torpid after-dinner drinks [...] (Inventions 79, 11. 1-3)

Following this, the speaker tries to attract the audience's attention by asking what they would like to hear. He doubles up as a kind of Master of Ceremonies who introduces acts in the club and responds to requests made by the audience members for a performance:

What, you want action?

Some attraction?

Now begins

The piano and the flute and two violins

Someone sings

A lady of almost any age

But chiefly breasts and rings

"Throw your arms around me - Aint you glad you found me"

(Inventions 70, 11. 11-18) 
His introduction leads on to the 1909 ragtime song 'The Cubanola Guide' performed by "a lady of almost any age" (Chinitz, T.S. Eliot 36-37). ${ }^{11}$ There is a doubling of the poet as both speaker (observer) and Master of Ceremonies (participant). The use of italics and double inverted commas for the line from the song enables the reader to make out that another voice is implied in the poem, the voice of the singer.

The next performance in the poem is that by an African-American dancer which is interesting given the close ties between African-American dance and jazz and the importance that Eliot placed on dance in his dramatic theories (Inventions 70, 1. 21). Dance is also implicitly present through the use of 'The Cubanola Glide', essentially a dance (Chinitz, T.S. Eliot 43).

Another way in which Eliot employs the imagery of the stage in his poetry is through the use of marionettes in his 'Humouresque (after J. Laforgue)' (1909), which arises directly from a stanza of Laforgue's poem 'Locutions des Pierrots' ('Asides from the Clowns') (Soldo 115). The second stanza of Laforgue's poem begins:

Encore un de mes pierrots mort;

Mort d'un chronique orphelisme;

C'etait un cœur plein de dandysme

Lunaire, en un drôle de corps.

(Laforgue, 'Locutions' 343, 12, 11. 4-8)

Another one of my clowns is dead;

Of chronic orphanhood, he died;

A lunar dandy's heart inside

Such a ludicrous little body. (Laforgue 66, 12, 11. 4-8)

As compared to this, 'Humoresque' (1909) starts with:

\footnotetext{
${ }^{11}$ See digital music collections for a copy of the score of Cubanola Glide on http://library.duke.edu/digitalcollections/hasm.a2362/pg.5/ accessed on 17 April 2008.
} 
One of my marionettes is dead

Though not yet tired of the game -

But weak in body as in head,

(A jumping-jack has such a frame). (Complete 602, 11. 1-4)

Playing with ideas in 'Humouresque', Eliot replaces Laforgue's living clown and introduces a children's toy, a "jumping-jack" which can also be a kind of puppet. Eliot's use of the marionette prefigures his idea of a puppet theatre à la Gordon Craig in the mid-1920s. Like Eliot, Craig espoused a need for a ritualised, non-realistic theatre and he saw masks and puppets as crucial to this aesthetic (J. Bell 54).

Since a puppet does not have an independent existence this stance is an extension of Eliot's anti-Romantic position besides being an integral part of his theory of acting as discussed in chapter one. There is an ongoing dialogue between the spectres and the marionette in 'Humouresque' which directs us towards the poem's dramatic nature:

'Haranguing spectres, set him there;

'The snappiest fashion since last spring's,

'The newest style, on Earth, I swear.

'Why don't you people get some class? [...]

(Complete 602, 11. 14-17)

The use of a new inverted comma at the start of every line highlights the presence of different voices that arise within the work. McCue has pointed to a similar use of inverted commas towards the end of part one of The Waste Land:

'Oh keep the Dog far hence, that's friend to men,

'Or with his nails he'll dig it up again!

'You! hypocrite lecteur! — mon semblable, — mon frère!'

(Complete 63, 11. 74-76)

Here, McCue observes that Eliot has inverted commas "opened at the start of successive lines". This kind of punctuation suggests "a new interrogator chiming in at every line" and leads to an "effect of cumulation, of voices within voices" (McCue 
10). While I do not believe that this interpretation of the emergence of different voices applies to the passage from The Waste Land given the similar semantic quality of the lines in the longer poem, it does apply to 'Humouresque' where the piping in of one new voice after the other is quite evident.

In 'Convictions' (Curtain Raiser) (1910) Eliot's marionettes are definitely on stage and while they do the bidding of their master, they seem to acquire a life of their own: "They see the outlines of their stage / Conceived upon a scale immense" (Inventions 11, 11. 3-5). Part of the reason for this humanization is the use of speech and dialogue in the poem. There is one part of a dialogue in the poem as one marionette 'speaks' to another":

And one, a lady with a fan

Cries to her waiting-maide discreet

"Where shall I ever find the man!

One who appreciates my soul;

I'd throw my heart beneath his feet.

I'd give my life to his control."

(Inventions 11, 11. 21-26)

Here, as the quotation marks reveal, the marionette 'addresses' her waiting-maid. Eliot is quite happy to disappear into this world of make-believe, revealing the characteristics of a future dramatist. It is also apparent that the marionettes are figures in a drama controlled by the speaker as part of the title includes the words: 'Curtain Raiser'.

Thus, through the presentation of several poems where the stage and the imagery of theatre plays an important role, Eliot was able to convey a sense of the dramatic. The use of myriad voices in these poems and the presentation of vaudeville and marionette theatres in them add to the dramatic quality of the works.

\subsection{The dramatic in the Sweeney poems}

Eliot moved towards writing in yet another style when he adopted the quatrain form for his Sweeney poems of Poems (1920). While these poems do not contain monologue or dialogue, or present their characters on the stage, they have a certain 
amount of tension and movement in them which enhance the characterization of their figures and introduce a sense of the dramatic. They seem to hint at dramatic moments, sometimes of a sinister kind, that are not fully elaborated.

Eliot's Sweeney is a conglomeration of different characters including Sweeney Todd, the semi-fictional demon barber of Fleet Street and a character who appeared on the Victorian stage (Mack 206), a real Dr. F. L. Sweaney, who was apparently a quack practising in St. Louis when Eliot lived there, and a Boston pugilist friend of Eliot called Steve O'Donnell (Crawford 28). Through the portrayal of Sweeney, Eliot returns to 'primitive' man, uninhibited by the mores and artificiality of upper-class society.

In the Sweeney poems, Eliot abandoned the free verse style of 'The Love Song of J. Alfred Prufrock' choosing, instead, the quatrain form. This was a result of Pound's advice to employ the style of French poet Théophile Gautier's Émaux et Camées (1852) (Kermode ix). Gautier and other poets of the French L'art pour L'art movement aimed to work on poems like a sculptor works on a work of art (Starkie 28). This would have appealed to Eliot and Pound in their shift towards Vorticism, especially given Pound's close interaction with the French sculptor Henri-Gaudier Brzeska. $^{12}$ The use of the quatrain form mixed with the effect of Imagism on Eliot lent these poems an intensity that perhaps was not seen in the English language before. The result of highlighting a particular moment was commented on by Pound who also used this form of writing at the time: "I catch the character I happen to be interested in at the moment he interests me. Usually a moment of song, self-analysis, or sudden understanding [...] I paint my man as I conceive him, et voilà toute!” (Qtd. in Coffman 123-124)

By concentrating on what a character does at a particular moment in his quatrains Eliot brings that moment and character closer to drama. The focus of the moment is on the particular movement or action of the character in a given situation which is essentially dramatic. However, one must point out that time in drama is different from time in poetry and that whereas most drama covers events over an extended period of time, Eliot is only able to capture, in his poetry, a specific moment of time. In this sense, his poetry can be compared to the Futurist's sintesi, which were extremely short and almost always plot-less plays, some barely a minute

\footnotetext{
${ }^{12}$ See Pound, E. Gaudier-Brzeska: A Memoir. New York: New Directions, 1970 for more on this interaction.
} 
long. The moment, as captured in Eliot's individual poems, gains in intensity due to the use of the restrained quatrain form. The ending of 'Mr. Eliot's Sunday Morning Service' has Sweeney shifting about in his bath, a striking image which carries much of the commentary that Eliot wants to make about dogmatic religion in the poem:

Sweeney shifts from ham to ham

Stirring the water in his bath.

The masters of the subtle schools

Are controversial, polymath. (Complete 55, 11. 29-32)

Sweeney's presence in the bath here is not only a pointer to the attempt to murder him in mock Agamemnon-style in 'Sweeney among the Nightingales' (G. Smith 45), but also looks forward to his discussion of the murderer who kept a girl's body in the bath in Sweeney Agonistes (Complete 124).

'Sweeney Among the Nightingales' (1918) has a dramatic moment centred around the uncertainty as to whether Sweeney is going to be the unsuspecting victim of a murder plot or whether he is actually just enjoying himself in a role-playing scene in a bordello. While normally action or movement can make a moment more dramatic, at this point in the poem, the very sense that there is an impending act creates tension and a sense of conflict which infuses the work with a dramatic quality. While Matthiessen claims that the poem possesses "an undercurrent of moving drama" and that Sweeney's plotted death is a human tragedy just like that of Agamemnon, the truth is that Sweeney's would-be murder is a parody of ancient Greek tragedy (129). The violent moment of action in the poem reveals its dramatic quality. The "circles of the stormy moon / Slide westward" as the woman in the Spanish cape makes a clumsy move on Sweeney (Complete 56, 11. 5-6). We are warned that the lady and Rachel, who tears at the symbolic grapes "with murderous paws", may very well "be in league" (Complete 56, 11. 23-26). What they have plotted is unclear, but we can imagine either an elaborate ménage a trios or a parody of the Agamemnon murder with Sweeney appearing as a corrupted version of the dead king.

As we have already noted, Stillman believes the poem possesses similarities to Eliot's marionette poems, likening the attempted move on Sweeney clumsily made by the woman in a Spanish cape to the practised move of a marionette in puppet 
theatre (126). What Stillman points to here is the dramatic nature of the lines owing to the movement of the character or figure:

The person in the Spanish cape

Tries to sit on Sweeney's knees

Slips and pulls the table cloth

Overturns a coffee-cup,

Reorganised upon the floor

She yawns and draws a stocking up [...] (Complete 56, 11. 11-16)

There is, of course, the connection to the ancient Greek drama of Aeschylus with the reference to Agamemnon's murder at the end of the poem (Complete 57, 11. 36-40). Agamemnon is the first play in Aeschylus' Oresteian trilogy and this connection to the Oresteia is continued later in Eliot's plays when he uses the third play in the trilogy, Eumenides, for the theme and plot of his 1939 drama The Family Reunion.

Sex and violence define Sweeney. In stark contrast to the indifferent dandy, Sweeney plunges into his affairs with gusto, albeit without much emotion (in the latter he is like the dandy). He does not intellectualise his feelings (at least not in the poems); we are not taken into his mind to see what he may be thinking; he only acts. In this sense, he is closer to being a dramatic character than Prufrock. To use an analogy from American drama, Sweeney is a hulking Stanley Kowalski of Tennessee William's A Streetcar Named Desire (1947) and not a refined or dandified Southern gentleman caller.

Matthiessen points out that Eliot "sets out to make his characters actual by confining his description of them to a perceived significant detail or characteristic gesture" (69). Thus Eliot presents us with some of the gestures or actions that Sweeney performs which bring him closer to being a dramatic character:

Apeneck Sweeney spreads his knees

Letting his arms hang down to laugh,

The zebra stripes along his jaw

Swelling to maculate giraffe. (Complete 56, 11. 1-4) 
It is through these movements that the work becomes more dramatic. For instance, in 'Sweeney Erect', the description of Sweeney shaving while the prostitute writhes on the bed parallels the actions during their recently-concluded sexual encounter and reveals something about each of these characters:

Tests the razor on his leg

Waiting until the shriek subsides.

The epileptic on the bed

Curves backward, clutching at her sides.

(Complete 43, 11. 29-32)

Thus, it is mainly through movement and a sense of tension that the dramatic emerges in the Sweeney poems. The reduction of the possibilities for the dramatic due to the absence of dialogue and monologue in these forms points to the likelihood that the writer was still uncertain as to the extent of dramatic elements he could use in poetry.

\subsection{Conclusion}

The presence of dramatic elements in Eliot's poetry after 1908 was the result of a combination of his reaction against neo-Romanticism and his ever-increasing interest in the theatre. The occurrence of these elements in the poems leads to an interesting and, at times, extremely powerful intermingling of the lyric and dramatic. This interrelationship is crucial to the aesthetic developed in The Waste Land, not surprising given that the poem was composed during the years in which Eliot was experimenting with and refining the nature of the dramatic in his poetry.

Subsequently The Waste Land itself has several dramatic elements. In my next chapter I will study the dramatic elements that emerged from the workshop production of parts one and two of the poem. Through this I hope to display how the lyric-dramatic interaction is a regular feature that runs through most of Eliot's career and reaches a climax in The Waste Land. 


\section{Chapter Three: From Poetry to Performance: The Lyric-Dramatic Interface in The Waste Land}

\subsection{Critics on the dramatic in The Waste Land; the workshop production}

Critics have for long viewed The Waste Land as dramatic in nature. As early as 1931 Wilson claimed that the poem owed "a large part of its power to its dramatic quality" which made it "peculiarly effective, read aloud" (113). In 1936, Seferis observed that Eliot's poetry was not lyric poetry in the manner of Mallarmé and Valery, but was essentially "dramatic poetry". He went on to observe that Eliot's words in his poems "do not flow as a complete, harmonious entity, as is the case with lyrical poetry" but instead contained "within themselves a kind of purely theatrical energy" (Seferis 156-57). In 1950, Dobree claimed that "dramatic movement" shaped The Waste Land (Grant 2: 612), while over twenty years later, in 1972, Bergonzi described Eliot's work as a “dramatic poem” (Bergonzi 91-92).

Through the very title of his article "The Waste Land: The Last Minstrel Show?" (1980), Sanders suggests that the poem possesses strong possibilities for performance. He observes that we can "take our choice of plays within the "play" of the poem choosing to view it as a series of variety acts just like in a minstrel show (Sanders 30). Similarly, Knowles (1998) states “The Waste Land's display of freaks and queens and psychics and hyacinth girls and cockney vaudeville acts gives the opening two sections of the poem, particularly, the format of a variety show" (20). By using the term "variety show" Knowles refers to the different acts in a music-hall performance. ${ }^{1}$ Crawford uses Eliot's own words to make the point that The Waste Land distilled the "dramatic essences" and infused them "into some other liquor" (Crawford 159; Eliot, 'Poetic' 635). More recently, in 2006, Raine asserted that "The Waste Land is Eliot's greatest dramatic work" (90).

Eliot himself seemed to have viewed his poem as approaching the dramatic. The writer and critic Bonamy Dobree recalled how Eliot "warmed" to him when the

\footnotetext{
${ }^{1}$ The New Encyclopaedia Britannica describes music-hall and variety as "popular entertainment that features successive acts starring singers, comedians, dancers, and actors and sometimes jugglers, acrobats, and magicians [...] The usual show consisted of six to eight acts, possibly including a comedy skit, a juggling act, a magic act, a mime, acrobats, a dancing act, a singing act, and perhaps a one-act play" (8: 443-444).
} 
former confided to the poet in 1924 that what he liked most about The Waste Land was "its dramatic movement". Dobree believed that this concept was very close to one of Eliot's "deep desires", a desire that perhaps became evident when Eliot claimed, in 1920, that "a large number of poets hanker for the stage" (Dobree 67; Eliot, Sacred 60). He was one of this "large number of poets". Eliot would not have failed to appreciate the performance elements in The Waste Land. This becomes more obvious when we read Virginia Woolf's recollection of how he had almost "performed" the poem for a group of friends while reading it aloud (178).

There has been at least one recorded attempt to present The Waste Land in a high-profile theatrical space: the staging of the poem as a dramatic production in a 35-minute one-woman show by Irish actor Fiona Shaw at New York's Liberty Theatre in 1996. This production was earlier made into a short film broadcast on BBC2 television in $1995 .^{2}$ The very fact that The Waste Land has been staged and also filmed and broadcast for television perhaps demonstrates that its dramatic potential has already been translated into reality.

I wrote to the BBC to request a copy of the film version of Shaw's performance but received no reply. In the absence of a copy of the performance I would prefer to refrain from passing judgment on the same. However, given that we live in the age of YouTube, I find myself drawn to making comparisons with versions of Shaw's recital of parts of The Waste Land which I believe bears some resemblance to the full staged version at Liberty Theatre. ${ }^{3}$ She does exploit the different voices in the poem in an attempt to create a sense of character, something which happened in my workshop production too, albeit with the use of different actors. Movement is not attempted, perhaps because these are readings/recitals. However, I believe that a one-woman show is at a distinct disadvantage when we

\footnotetext{
${ }^{2}$ See Gussow, M. 'Opening up T.S. Eliot in all the Empty Places'. New York Times, Nov. 16, 1996, at the following url for a preview of Shaw's performance on the New York stage: http://query.nytimes.com/gst/fullpage.html?res=9E00E5D6173AF935A25752C1A960958260\&sec=\& spon=\&pagewanted=all, accessed on March 25, 2010.

See also the website of the British Film Institute for details of the television film: http://ftvdb.bfi.org.uk/sift/title/540508?view=transmission accessed on March 25, 2010

${ }^{3}$ The site: http://www.youtube.com/watch?v=k8QKvCf1FWU, contains Shaw's recital of the rich lady scene and the pub scene in part two of The Waste Land (accessed 21 November, 2010). Another site: http://www.youtube.com/watch? $=5 \mathrm{NV} 2 \mathrm{KyGp} 2 \mathrm{ak} \&$ feature=related (accessed 21 November, 2010, presents a stand-up reading of the hyancith girl and Madam Sosostris sequences for which Shaw dons a skirt and a myriad of different voices to present different characters. There is the use of a pianist in this sequence to bring out some of the rhythms in the poem.
} 
look at possibilities for movement and choral elements in The Waste Land which were crucial to the workshop production.

Reviewing Shaw's stage performance on November 18, 1996, New York Times drama critic Ben Brantley describes The Waste Land as "a poetic Tower of Babel, teeming with theatrical richness" (online). He gushes about "a raw emotionalism beneath the work's academic layers" which he claims is "often far more stirring than Eliot's mannered plays". While he admits that The Waste Land is "not the sort of thing to leap spontaneously from page to stage", I believe that there are certain dramatic elements in the poem that allow us to explore the possibilities of a performance more vividly.

While busy putting together The Waste Land Eliot was also in the process of devising his theories of drama. I believe that this theorizing is reflected in the style of his poetry around this time and ensures the presence of dramatic elements in it. This meant that the interrelationship between the lyric and the dramatic reached a critical juncture in The Waste Land with the poet having arrived at a kind of tipping point where poetry was just about to cross over into drama.

The working of the lyric-dramatic interaction in the poem did not go unnoticed. As early as 1923, Eliot's friend and fellow writer Conrad Aiken described The Waste Land as presenting perceptions and feelings in a dramatic and lyrical manner (35). Logenbach, too, observes such a style at play, claiming that Eliot's note on Tiresias allows some "interpreters to read the poem as a lyric utterance, equating Eliot with his "protagonist"” and that such a reading "ignores the poem's uneasy position between lyric and drama" (61).

The poem's occupation of this "uneasy position" is the result of Eliot's experimentation with the interaction between the lyric and dramatic in the work. By conducting theatre workshops for a representative part of the poem I hoped to identify and study the emergence of the dramatic elements of the poem so as to arrive at a better understanding of the lyric-dramatic interaction in the work. The aim of these workshops was not to prove that the poem could be performed as drama per se but to understand the significance of The Waste Land within the overall context of the lyric-dramatic interaction in Eliot's work. The poem is never strictly going to be seen as drama, nor is it desirable that it should be viewed as such.

I chose to workshop The Waste Land and not other, earlier poems because I believe that while Eliot was experimenting with different forms such as dialogue, 
theatrical imagery and movement in his earlier poems, these experiments largely involved only one or two dramatic elements per poem. In contrast, The Waste Land involves an amalgamation of many of these elements and, in this sense, signifies a culmination of Eliot's experimentations with the nature of the lyric-dramatic interaction in his poetic work. As Rees puts it, The Waste Land "represents a consolidation and recapitulation of nearly all of Eliot's previous technical accomplishments" (165).

The workshops for my production involved eight actors working over a period of six weeks and led to a performance of parts one and two of the poem at Victoria University of Wellington in mid-September 2008. For our production we employed a bare stage with a central black box as a set piece and some chairs which were brought in or taken off as needed. There was little attempt made to explicate the poem or discuss its meaning and many different connotations with my actors during workshops since it was feared that over-intellectualization would affect the nature and possibility of action especially given The Waste Land's varied borrowings from myth and literature. Any attempt to explain or explicate meanings beyond a point would have possibly resulted in an endless discussion of intellectual niceties and could have brought the possibility of directorial bias to the fore. Moreover, it would have worked against the goals of the production - that is the need to discover the dramatic elements in The Waste Land through the workshopping of the text rather than through any artificially imposed readings of it.

Instead, the actors were provided with sections of the poem and asked to work on a performance based on the same passage in two different groups. After generally devising at least two performances per section, one each by each group, the actors would return to it as a single unit, usually during the next workshop, and attempt to arrive at a consensus through discussion regarding the best performance aesthetic for the section in question. This was done after watching several different performances of the same section or scene.

The process ensured that we had worked out at least two different versions of each section and that we had many individuals thinking about the piece together in a fashion that reduced any directorial bias. If the actors could discover dramatic elements in the poem on their own through the workshops without being overly dependent on the director then we could argue more strongly that these elements were inherent to the poem. Since we had at least two performance versions for each 
scene we could actually have performed two nearly completely different versions of parts one and two for the workshop production, but had to ultimately choose one. For reasons of simplicity, I have chosen to deal with the scenes used for the workshop performance during my analysis. The alternative versions of the devised scenes that emerged from the workshops but were not used in performance may be found in the workshop reports in the appendix of this thesis. Decisions during workshops were made by the group in its entirety with individual actors providing inputs. They were accepted by the actors playing the roles only when those actors were comfortable with such choices.

One of the objectives of the workshops was to come up with a list of dramatic elements that would emerge from the poem and which could be used later to analyse the workshops and the poem in the thesis. This list is mentioned in the introduction to the thesis and includes the following elements: movement, the use of voice or voices, dialogue, character, time, rhythm, tension or conflict, choral elements and music. In this chapter I will look at the manner in which these particular dramatic elements materialized from the poem with reference to the workshop production and how these elements interacted with or even arose from the lyrical quality of the poem itself to bring the work to the edge of drama. Through this I hope to demonstrate how the lyric-dramatic interaction in Eliot's career arrived at a crucial moment in The Waste Land, a moment which precedes his crossover into the world of playwriting itself.

\subsection{Dramatic elements in the production}

\section{Voices, dialogue and audience}

In his book on the dramatic monologue, Sinfield claims:

Eliot's The Waste Land is [...] a sequence of dramatic monologues which challenges the reader to discern connections. We can distinguish clearly the speeches of Marie at the beginning, the barmaid in the second section and Tiresias in the third. For much of the remainder it is difficult to be sure who is speaking, or even when one speaker ceases and another begins. (40) 
Sinfield rightly suggests that there are several voices in The Waste Land and indicates the difficulties in segregating these voices. Seed too refers to the "bewildering sequence of voices" in the poem and points out that the original title of the poem, 'He Do the Police in Different Voices', signals this feature (94). Dickens, from whose novel, Our Mutual Friend, Eliot's planned title was taken, was himself a brilliant performer of his own work, able to present the voices of his different characters on stage during his various speaking tours. ${ }^{4}$

There were different ways in which the voices of The Waste Land emerged during the workshop production of the poem in the theatre. The use of punctuation marks such as inverted commas, the presence of different languages, the changes of tone and the sense of an audience being addressed were some of the more direct ways in which these voices stood out. The presence of several voices in the poem is a feature that it shares with earlier Eliot poems such as 'The Love Song of J. Alfred Prufrock' and 'Suite Clownesque'. While the voices do not always seem to interact with each other, their very occurrence increases the possibility for the dramatic. This is because when different voices exist there is a potential for an audience, as in the case of a dramatic monologue or soliloquy, or for dialogue-like interaction and conflict that emerges due to the intermingling or juxtaposition of these voices. Some of Eliot's earlier poems which employed the metaphor of the stage, such as 'Suite Clownesque', or his dramatic monologues which used or suggested an internal auditor, such as 'Portrait of a Lady', possessed the sense of an audience being addressed. This is something that comes across in some of the dramatic monologues of The Waste Land too.

A blend of voices is evident right from the epigraph, which is taken from Petronius' first-century Latin novel Satyricon, where the narrator, the rich freedman Trimalchio tells his dinner guests what he once saw at Cumae:

\footnotetext{
${ }^{4}$ The foundling Sloppy in Dickens' Our Mutual Friend is, according to Betty Higden, "a beautiful reader of a newspaper. He do the police in different voices" (198).
} 
Nam Sybillam quidem Cumis ego ipse oculis meis vidi in ampulla

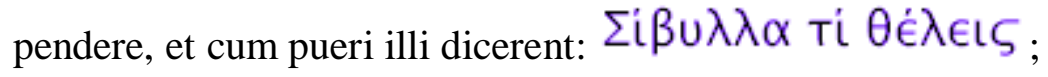

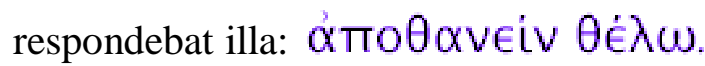

(Petronius, Satiricon 36)

In fact, I actually saw with my own eyes the Sibyl at Cumae dangling in a bottle, and when the children asked her in Greek: "What do you want, Sybil?" she used to answer: "I want to die."

(Petronius, Petronius 67)

In this scene, different voices seemed to emerge as indicated by the use of the punctuation marks and by the different languages used by the speakers in the text. In the original epigraph the narrator speaks in Latin, while the children and the Sibyl speak in Greek, which provides a clear differentiation between the narrator's voice and the other voices. The voices also arose because of the meaning and setting of the words in the original text. The narrator, in the production, played a priest-figure and recited the Latin words; his voice was linked to that of Trimalchio telling his tale. One of the actors playing the children asked the Sibyl what she wanted leading to the Sibyl's expression of her desire for death and the subsequent collapse to the floor of all actors except the one playing the Sibyl. The interaction between the Sibyl and the child was a direct dialogue which arose out of the words from the text itself.

With the lines from the Countess Marie section the actors chose to use different figures to play Marie based on the voices and characters that they could decipher from the lines. The first Marie was the narrator who established herself on the black box at centre and presented a monologic recounting of her past. A second Marie was in a 'café' with a male companion and spoke the line in German (Complete 61, 1. 12). The actors believed that since Eliot used a line in German, a change from the previous lines, this should be spoken by another figure:

Summer surprised us, coming over the Starnbergersee

With a shower of rain; we stopped in the colonnade, 
And went on in sunlight, into the Hofgarten,

And drank coffee, and talked for an hour.

Bin gar keine Russin, stamm aus Litauen, echt deutsch.

(Complete 61, 11. 8-12)

Although the speaker was essentially the same here in terms of overall character, the fact that the voice emerged from a different time and setting and used a different language and tone prompted the actors to imagine another speaker on stage. By contrast to the first Marie figure who was narrating a past event, the second, Germanspeaking Marie seems to respond to a question from a companion as is evident from the translation of the line:

Bin gar keine Russin, stamm aus Litauen, echt deutsch. (Complete 61, 1.12)

I am not Russian at all; I come from Lithuania; I am a real German.

(Trans. in Southam 107)

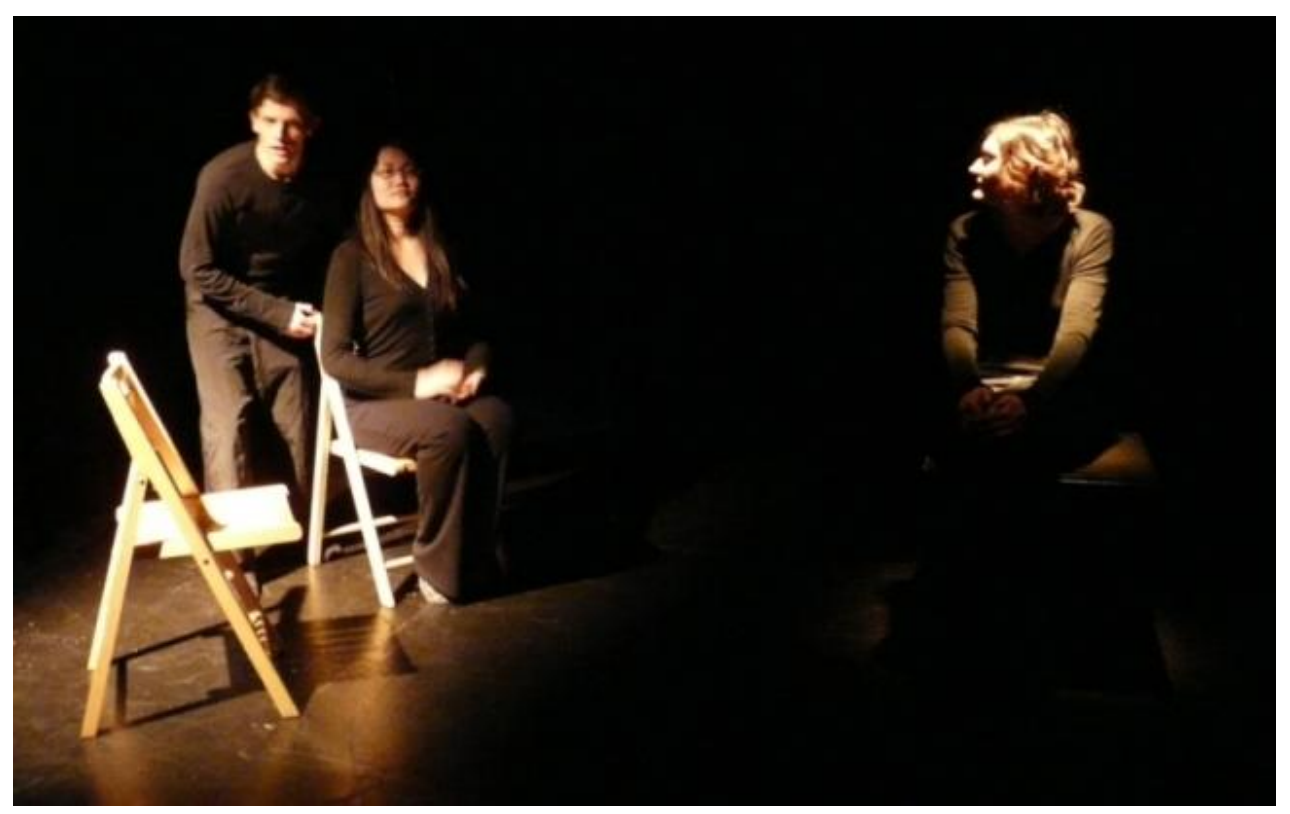

Figure 1: Marie in the café with a male companion and on the box

This presence of a companion who listens to Marie and who has probably asked a question which elicits the above answer increases the dialogue-like quality of the scene (see Figure 1 above). The immediacy of tone of the speaker here is in contrast to the reminiscent tone of the older Marie providing another clue to the presence of 
different kinds of voices here. Seed claims that some of the lines of Eliot's speakers in The Waste Land form part of an overheard conversation which is the case with the scene involving Marie in the café (99). Gardner is more specific when she says that "we are at least aware of someone, of a silent partner to a conversation in a Munich café" (Art 89). This difference between who is being spoken to is something that emerges from the text and perhaps allowed the cast to present Marie through different actors.

The figure of Marie who remembers the past does not seem to be speaking to a listener but instead indulges in a kind of internal monologue, or semiShakespearean soliloquy. In this sense, the passage is more lyrical when she speaks as opposed to when the second Marie is heard in conversation. This juxtaposition of the two passages highlights the interaction between the lyric and dramatic in this section and leads to a kind of dramatic tension, a dramatic element which I will explore in greater detail in a later section of this chapter.

In the sequence which begins "What are the roots that clutch?" (Complete 61, 1. 19) the actors employed two narrators - male and female - prophet-like figures who split the lines among themselves. The group felt the need for two characters here partly because of the line which appeared in parenthesis: "(Come in under the shadow of this red rock)" as opposed to the other lines in the passage (Complete 61, 1. 26). These lines may seem more lyrical than dramatic as the voice of the prophet that they imitate is almost always a solitary one crying in the wilderness. However, the fact that the actors shared the lines gave rise to a greater sense of dialogue and drama in the performance. This splitting was not without its genesis in the text. The lines that Eliot uses are taken from voices in three different books of the Bible: Ezekiel, the Book of Isaiah and Ecclesiastes and are, in this sense, the amalgamation of these different voices. ${ }^{5}$ What may make for a more compelling argument, however, is the sense that the lines have a collective or communal feel about them; they are addressed to a larger community which includes the prophet himself. This sense was portrayed by the actors who sometimes directed the lines at the audience as a kind of accusation and sometimes aimed the words at each other.

\footnotetext{
${ }^{5}$ See Southam 107-108 for more details regarding the origin of these lines of the poem.
} 
What are the roots that clutch, what branches grow

Out of this stony rubbish? Son of man,

You cannot say, or guess, for you know only

A heap of broken images [...] (Complete 61, 11. 19-22)

The sense of a wider community or audience being addressed by the speaker emerges also in the use of the second person "you". The fact that the speaker asks a question (even if it may be a rhetorical one) increases the feeling that the line is aimed at an audience and seems to have ensured that the actors directed that line in particular at the audience.

Voices also materialized from the poem through the use of inverted commas. The actors were quick to pick up on the presence of inverted commas in the sequence in the hyacinth garden to uncover a new voice (Complete 62, 11. 35-36):

'You gave me hyacinths first a year ago;

'They called me the hyacinth girl.'

- Yet when we came back, late, from the hyacinth garden, Your arms full, and your hair wet, I could not

Speak, and my eyes failed [...] (Complete 62, 11. 35-39)

The first two lines of this passage, spoken by the 'hyacinth girl', are followed by a set of lines which are not in inverted commas and appear to be an internal monologue or what Mayer has called a 'psychologue' (see Chapter 2). For this reason the actors assumed they belonged to another speaker, a Hyacinthus-like companion for the 'hyacinth girl'. This section of the poem involves a blending of internal monologue and outer speech, a kind of dédoublement, in a manner similar to some of Eliot's earlier poems such as 'Portrait of a Lady'. In a dramatic production of the poem both the outer speech and the inner monologue are heard openly on stage. The encounter in the hyacinth garden brings out a dialogue-like quality inherent in the poem, something which does not necessarily make it dialogue, but which brings it closer to being dramatic. However, it is important to remember that Hyacinthus' 'psychologue' is an internal, lyric utterance; in his inability to act or love and in the use of the 'psychologue' here he is somewhat similar to Prufrock. This interaction of 
lyric and dramatic elements in the work actually heightens the impact of the scene when performed in the theatre due to the tension between the elements.

Two more voices emerge around the moment in the hyacinth garden. These belong to the sailor lad from the opening scene of Wagner's Tristan und Isolde who is heard singing the four lines beginning "Frisch weht der Wind" (Complete 61, 1. 31; Wagner, Tristan 1.1,2-3) before the hyacinth garden sequence, and the shepherd from Act Three of the same opera whose line about the desolate sea: "Oed' und leer das Meer" appears after the description of the encounter in the garden (Tristan 3.1, 108). The Wagnerian lines were sung offstage by a male actor in the production. The fact that these lines were in another language and in italics made the actors conscious that they were not sung by the speakers in the garden, but were generated by a different voice. While the use of the Wagnerian songs out of their context may seem to highlight the lyrical quality of the lines over the dramatic, their sandwiching of the encounter in the hyacinth garden in the performance allowed for dramatic elements to emerge as well. The juxtaposition of the lyric voices from Wagner against the more dramatic voices in the hyacinth garden was another factor that helped to highlight the interaction between the lyric and dramatic in this scene.

In the Sosostris sequence, the actors used a narrator who was also an assistant-like figure for the clairvoyant. The presence of Madame Sosostris as a separate character with a voice of her own is quite clear because she directly addresses a client during her Tarot pack reading as can be made out by the use of the second person "your": "Here, said she, / Is your card, the drowned Phoenician Sailor" (Complete 62, 11. 46-47).

The actor playing Sosostris directed her lines at the audience and the accompanying gestures made by her assistant, who was miming the pictures on the different cards, were also aimed at the audience. Thus the audience were largely made to assume the role of Madame Sosostris' client in this sequence. The dialoguelike sense that came through in this scene as Sosostris interacted with her 'client', the audience, emerged directly from the lines:

I do not find

The Hanged Man. Fear death by water.

I see crowds of people, walking round in a ring.

Thank you. If you see dear Mrs. Equitone, 
Tell her I bring the horoscope myself:

One must be so careful these days. (Complete 62, 11. 54-59)

Sosostris is evidently engaged in a Tarot card reading but, more importantly, her change of tone from that of the serious to that of everyday conversation in the last two lines makes us even more aware that she has an audience. While the actor playing Sosostris chose to direct the last three lines in this passage towards her assistant, the narrator, there was still essentially a sense of dialogue that arose from this moment. In the alternative version that emerged from the workshop Sosostris directed these lines directly at the audience, thus bringing out this aspect of the dramatic in the scene.

In the sequence beginning "Unreal City" (Complete 62, 1. 60) the actors employed a narrator standing on the box to recite the descriptive lines about the London crowd who were marching about below him. However, they also used the figure of Stetson, the eternal soldier, who was separated from the crowd when the narrator-speaker confronted him. This figure was based on the fact that the speaker shifts from narration to dialogue, calling out Stetson's name and directly addressing him:

There I saw one I knew, and stopped him, crying: 'Stetson!

'You who were with me in the ships at Mylae!

'That corpse you planted last year in your garden,

'Has it begun to sprout? Will it bloom this year?

'Or has the sudden frost disturbed its bed?

(Complete 62-63, 11. 69-73)

The repeated use of the second person "you" and "your" here and the inverted commas helped the actors to distinguish that these lines, from the word "Stetson" onward, were addressed to another character on the scene. These lines are not narration but are part of direct speech as suggested by the change of tense from past to present. They lead to a sense of dialogue arising from the confrontation between the speaker and Stetson. There is also a change of tone from subdued and morose to angry and confrontational as the speaker moves from narration to dialogue thus revealing that he is now directly in conflict with Stetson. The shift 
is, in effect, one from the lyrical voice of the speaker describing the scene to the more dramatic voice addressing Stetson.

In the exchange between the rich lady and her male partner in part two, the lines which were not in inverted commas were spoken by the partner in a manner similar to the hyacinth garden sequence:

'My nerves are bad to-night. Yes, bad. Stay with me.

Speak to me. Why do you never speak? Speak.

What are you thinking of? What thinking? What?

I never know what you are thinking. Think.'

I think we are in rats' alley

Where the dead men lost their bones. (Complete 65, 11. 111-115)

Here, Eliot intersperses the use of inverted commas for outer speech by the woman with their absence for the man, indicating that this voice is perhaps an interior monologue. ${ }^{6}$ The actors used the two voices in the poem to present the conflict between the man and woman. Dialogue-like features emerged here mainly through juxtaposition of outer speech against interior monologue as in the hyacinth garden sequence. Seed refers to this as a kind of pseudo-dialogue where the silent 'answers' of the listener reveal the meaninglessness of the occasion (103). While dialogue-like features emerge from the poem it must be clarified that they are not the same as pure dialogue itself. Seed asserts, "It is typical of The Waste Land that questions are not met with any meaningful responses so that we are left with indications of the desire for dialogue rather than its realisation" (103). The presence of this desire for dialogue in the text translates more clearly into dialogue-like possibilities in performance. However, the lyrical aspects of the text remain inherent in the section thanks to the fact that the lines are not in inverted commas but are part of 'psychologue'.

In the pub scene at the end of part two, the presence of a second Cockney woman who chiefly listens to the seemingly ceaseless chatter of the first and chimes in occasionally became clear to the group. This may have been because of the

\footnotetext{
${ }^{6}$ Writing about these lines, Grover Smith claims "The absence of quotation marks from the man's lines probably means that in reality he does not answer at all, and only meditates his thoughts" (81). McCue describes this section as containing "the punctuation of paranoia" because the replies are not marked as spoken and they "may be only thoughts, whether schizophrenic self-reassurance or the dismissive musings of a narrator" (11).
} 
appearance of her lines in parenthesis and the conversational and gossip-like tone of both women:

You ought to be ashamed, I said, to look so antique

(And her only thirty-one).

I can't help it, she said, pulling a long face,

It's them pills I took, to bring it off, she said.

(She's had five already and nearly died of young George).

(Complete 66, 11. 156-160)

In our production the second woman spoke the lines in parenthesis and directed them at the first speaker in what was a kind of dialogue. It is also possible that the second speaker can directly aim the lines at the audience itself. The second speaker here is eager to say something to add to the non-stop speech of the first and is only able to put in a single line at a time before the first speaker takes over again. The interruption of the Cockney women's dialogue by the publican gives us a third voice interrupting the first two as in an everyday conversation that occurs towards closing time in a pub (G. Smith 83). This new voice is indicated by the capitalization and becomes associated with the publican, a character used by the actors, on account of its meaning and repetition: "HURRY UP PLEASE ITS TIME" (Complete 65, 1. 141).

In addition to these three characters the group employed three more actors in the pub. This was because they believed that there were more people in the pub who were part of a chorus saying goodbye to the Cockney women at the end of part two. The mention of Bill, Lou and May in the sequence and the fact that the first set of "goonights" were aimed at them may have made the actors imagine that these three additional characters were present in the pub. Additionally, saying goodnight is a performative act, an "utterance that effects an action" (OED online), the action of going home or going to bed. The actors divided the lines here between the two Cockney women and the others sitting in the pub. The exchange of goodnights enhanced the dialogue-like nature of this scene overall:

Goonight Bill. Goonight Lou. Goonight May. Goonight.

Ta ta. Goonight. Goonight. (Complete 66, 11. 170-171) 
Thus the possibility of voices creating dialogue or approaching dialogue-like qualities, combined with a sense that an audience is being addressed, is crucial to the dramatic nature of The Waste Land. Where these elements were both present the dramatic emerges more clearly from the poem making it easier for the actors to present these scenes on stage. We also observe that lyrical elements often existed in the poem even as dramatic voices seem to emerge simultaneously.

\section{Rhythm, movement and ritual}

Movement is an important dramatic element, linked to Eliot's ideas on rhythm and ritual drama in his criticism and it emerged powerfully from the text during the production. As is evident in the word 'drama' itself, which is derived from the Dorian word 'dran' meaning 'to do' (Aristotle 15; also Barnet 210), movement lies at the heart of the action presented on stage. Aristotle placed great emphasis on movement. His definition of tragedy underscores this, counting the art form as "the imitation of an action", something which was "enacted by men in action" (Aristotle $11,23)$.

Rhythm plays a crucial role in providing movement in drama. In his essay 'The Task of Drama', expressionist playwright Walter Hasenclever asserted that rhythm was to the writer what the "formula is to the mathematician" (31-32). When we use the word "rhythm" we may refer to the use of any one of its constituent elements such as a beat, accents or tempo (Goodridge 26). The rhythm in poetry often emerges from the number and arrangement of feet in each line which creates a kind of musical beat. Eliot, of course, was keenly aware of the effect of the rhythm of poetry on movement in drama. In his essay 'Poetry and Drama', he analysed the opening scene of Shakespeare's Hamlet which presents the soldiers on their nightwatch and the appearance of the revenge-seeking ghost of Prince Hamlet's father. Here, Eliot claims that owing to the rhythm of the poetry, "a musical design" emerges in the scene "which reinforces and is one with the dramatic movement" (On Poetry 76). Through the examination of the role of verse rhythm in this scene, Eliot concluded that "verse is not merely a formalization, or an added decoration" in drama, but "intensifies drama" (On Poetry 77). Similarly, I believe that the rhythm of Eliot's verse in The Waste Land increases and enhances the intensity of the dramatic 
elements in the poem by aiding with the movement of the actors. The physical movement on stage emerged as it were from the lyrical rhythms of the poem.

Through ritual, Eliot hoped to bring together lyrical rhythm and dramatic movement in the same text. In his critical writings, as we have already seen, Eliot stressed the importance of movement in acting, especially the ritualised movement of the ballet (Selected 47). He believed that drama originated in the dithyrambic ritual of ancient Greece. Rhythm became important, too, in this context since the action or movement of ancient Greek drama and ritual was aided by a sense of rhythm created by music and generated through dancing.

The sense of ritual and rhythm evident in sections of the poem generated specific patterns of movement for the actors on stage. The ritualistic element in the epigraph helped to lend this scene its sense of movement. In the scene, the Sibyl entered and was followed by her children or disciples and the priest-figure. The actors developed this specific entry in order to preserve the sense of ritual that they observed in the scene. They believed that the Sibyl, as a kind of religious figure, would have people following her or encircling her in a manner befitting her status.

The rhythm of the opening seven lines of 'The Burial of the Dead' provided the tempo needed for the actors to time their rising from their lying-down positions previously adopted when they had collapsed at the end of the epigraph. In this scene, the actor who was earlier playing the Sibyl came down from the box and positioned herself downstage to become a narrator. While she was speaking the lines the rest of the actors slowly began to rise from the floor in rhythm with the words. We found that we could use the last word of lines one to three and five and six, as a regular beat to help with the movements and time it so that all the actors had almost completely risen by the end of the passage:

April is the cruellest month, breeding

Lilacs out of the dead land, mixing

Memory and desire, stirring

Dull roots with spring rain.

Winter kept us warm, covering

Earth in forgetful snow, feeding

A little life with dried tubers. (Complete 61, 11. 1-7) 
The words at the end of lines one to three and five and six are present participles i.e. "breeding", "mixing", "stirring", "covering" and "feeding". Raffel notes that these line endings establish "one of those insistent rhythms of which Eliot's poetry is always composed" (73). The punctuation, the commas used in these lines which appear before each present participle provided us with a rhythm that helped the actors to time their movements. Movement for the production was thus aided by the natural rhythm of the poetic lines (see Figure 2 below).

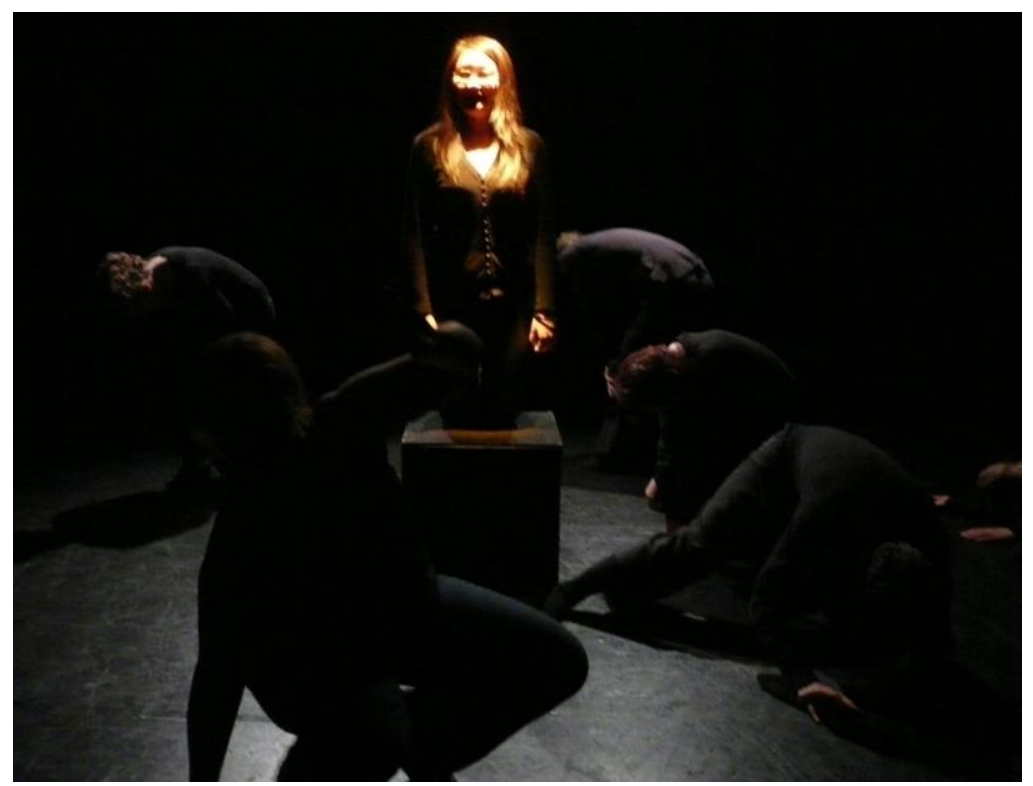

Figure 2: Rising in rhythm to the opening lines of 'The Burial of the Dead'

Rhythm played a crucial role too in developing the movement in the "Unreal City" scene (Complete 62-63, 11. 60-76). The actors developed a rhythmical walk for the London crowd of workers who trudge to their offices daily. The beat or tempo of this walk matched that of the narrator's spoken lines and created an eerie, yet appropriate background to his monologue. The actors discovered that they needed to maintain a rhythm that was neither too fast nor too slow, something that went well with the pace of the narrator's lines. Thus the metre of the lines and their spoken rhythm allowed them to time the movement for the performance, a movement which seemed extremely effective for this scene in particular.

The question may be raised whether the narrator learned to say his lines to the rhythm of the marching or vice-versa. I believe it worked both ways. The lines of poetry possessed the rhythm necessary to make this scene more effective dramatically if used in an appropriate manner. The marching crowd merely 
reinforced the rhythm already present in the lines and, through it, added to the feeling of doom evident in this passage of poetry (see Figure 3 below).

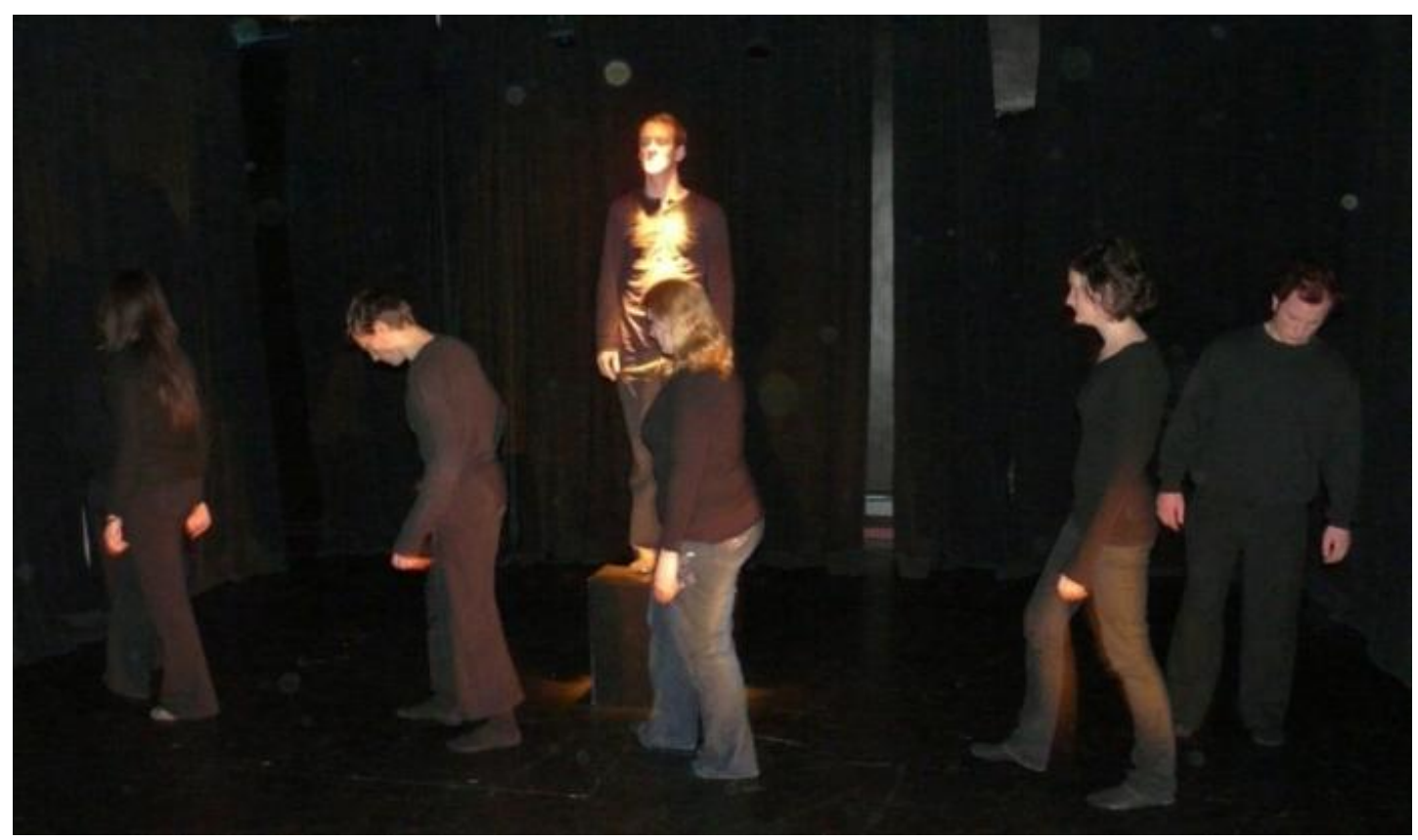

Figure 3: A crowd flowed over London Bridge, so many (Complete 62, 1. 62)

I think that the rhythm for the actors developed partly from the pauses used quite regularly in the passage as indicated by commas and full stops. But, more importantly, it arose from the regular number of feet (pentameter) in most of the lines as contrasted against the constant rising and falling of light and heavy syllables within that overall rhythm. This constant flux of stresses gave rise to a feeling that there was a marching crowd of people who were crossing a bridge:

Unreal City,

Under the brown fog of a winter dawn,

A crowd flowed over London Bridge, so many,

I had not thought death had undone so many.

Sighs, short and infrequent, were exhaled,

And each man fixed his eyes before his feet

Flowed up the hill and down King William Street

To where St. Mary Woolnoth kept the hours

With a dead sound on the final stroke of nine.

(Complete 62, 11. 60-68) 
The crowd came to a halt with the increase in the number of heavy syllables as they approached the words "final stroke of nine". The fixed nature of the office workers' march conveyed a sense of boredom and despair that employees feel when they set out to work for a thankless job each morning.

Thus ritual and rhythm helped the actors in devising and timing their movements in certain sections of the poem. Where the lyric rhythm and dramatic movement worked well together, especially in the "Unreal City" sequence, the scene seemed to come across more powerfully on stage.

\section{Tension and conflict}

As a dramatic element, tension arises from rhythm, movement and dialogue. Maeterlinck has argued that action will always be the "sovereign law of the stage" and that it rises from the "struggle between diverse conflicting passions" (102-103). In a similar vein, Brecht has told us that "a particular passion of utterance, a certain emphasis on the clash of forces are hallmarks of the "dramatic"' (70). This sense of conflict was quite noticeable in the dramatic presentation of The Waste Land as we moved from scene to scene. The essential conflict in the performance arose largely out of a tension of words and movement which paralleled a tension between the lyric and the dramatic in the poem.

In the epigraph, there is a conflict between the mortality and the relative freedom of the Sibyl's disciples and the immortality and caged existence of the Sibyl herself. This conflict in the language of the text led to the actors presenting the Sibyl as trapped between the two arms of a human cage in the performance even as she knelt upon the box. As opposed to this the disciples could go round the Sibyl, even though they were still bound to her. Their collapse at the end of the scene also emerged from the opposition between the disciple's mortality and the Sibyl's desire for death. The dramatic tension caused by the setting and the movements in this scene emerged directly from this sense of conflict in the text. The tension between the Sibyl's fixed nature and the ability of the children to move around her paralleled the relationship between the lyric and dramatic in this scene. 
I believe that this tension caused by the presence of both lyric and dramatic elements in the same scene also emerged through a physical separation between actors. Pfister suggests that such separation occurs not only horizontally but vertically, and argues that the vertical spatial axis in a dramatic space is vital, if often ignored (258). This spatial dynamic helped bring out the sense of conflict in several scenes in the production. For example, in the epigraph, the Sibyl was kneeling on the box, while most of the other actors surrounded her in a circle, allowing the Sibyl to occupy a higher plane because of her fixed, lyrical role and her greater spirituality.

Similarly, the lyric-dramatic tension between the figures in the hyacinth garden sequence was reflected in the vertical positioning of the actors on stage. The female actor, who had lines of direct speech, stood and walked around the male actor, while the male, who indulged in an interior monologue, occupied a stationary position on the floor with his knees up against his chin (Complete 62, 11. 35-36). This foetal position seemed to reflect his inability to love and contrasted sharply with the female's movement towards him, bringing to the fore the tension in this scene.

Such tension also arose in the "Unreal City" scene in several ways. Firstly, there was the tension caused by the opposition between the still narrator who could only speak and the fixed movements of the crowd that had no voice. There was also a spatial tension as the narrator was fixed on the box above the crowd while the crowd of people marched below him. This paralleled and reflected the lyric-dramatic tension in the poem overall.

When we shift to the exchange between the woman and her partner in part two the tension rises through the rhythm of the words spoken by the woman as well as through the repeated use of questions which parallels the narrator-Stetson exchange. A pattern emerges through which the conflict between the couple becomes apparent: "“What are you thinking of? What thinking? What? / I never know what you are thinking. Think"' (Complete 65, 11. 113-114). As the first line spoken by the woman advances, the questions become shorter and sharper, more accusatory in tone. They include words from the previous sentences but these words are now reduced in number. Also, the number of heavy syllables increases with the rising tension and the conflict seems to come through more strongly when the longer sentence, "I never know what you are thinking", which makes us suspect that the tension is easing, is followed, instead, by a sharp, single word which is almost a command thrown at the partner: "Think". The nature of the sentence also varies in this passage; it goes from 
a question ("What are you thinking of ?"), to a statement ("I never know what you are thinking") and finally to a command ("Think") which demands action or a response from the partner. The conflicting tension of the lines ends in the cool, casual and seemingly dislocated male partner saying or thinking: "I think we are in rat's alley / Where the dead men lost their bones" (Complete 65, 11. 115-116).

The tension of the language of the poem was paralleled by that created by opposing movements or spatial positions taken throughout the performance. In the performance the woman was largely seated upon the black box while her partner stood passively at a far corner from her, not bothering to look at her. The physical distancing of the couple paralleled the emotional distance between them.

The tension evident in the poem helped to highlight the differences between characters and their inability to communicate with each other in The Waste Land which leads ultimately to a breakdown of human relations, one of the chief themes of the poem. Its presence in the work brought to the fore some of the element of conflict in the dialogue-like exchanges and in the settings of the poem which paralleled the lyric-dramatic interaction in the work.

\section{Chorus and music-hall}

Moulton claims that the "Chorus was the bond between the lyric and dramatic elements" in Greek tragedy (65). To this extent the presence of a choral element in parts of The Waste Land helps point us to the interaction between the lyric and dramatic in the poem. The word 'Chorus' originally refers to the organized band of singers and dancers in the religious festivals and dramatic performances of ancient Greece (OED online). It is debatable whether The Waste Land is driven by any single figure or character. In fact, we presented parts one and two of the poem on stage without using a single character as a binding force through the performance.

While one might argue that this might have changed if we were aware of Tiresias' presence in part three of the poem, I do not believe that the mention of Tiresias in that part would have affected the actor's presentation of parts one and two. In his notes to The Waste Land Eliot wrote: 
Tiresias, although a mere spectator and not indeed a 'character', is yet the most important personage in the poem, uniting all the rest. Just as the one-eyed merchant, seller of currants, melts into the Phoenician Sailor, and the latter is not wholly distinct from Ferdinand Prince of Naples, so all the women are one woman, and the two sexes meet in Tiresias. What Tiresias sees, in fact, is the substance of the poem. (Complete 78)

I would argue that this note is not only contrary to the disjointed and fragmentary nature of The Waste Land it is also not in keeping with the presence of the different dramatic voices that emerge through the work. The Notes were an add-on that only emerged thanks to the need for more pages during the publication of the first separate edition of the poem and as a response to the perceived obscurity of the work. The argument for the central controlling figure of Tiresias does not provide us with meaningful answers to the questions that the poem poses. One must remember that The Waste Land was initially a mass of separate poems that were brought together by the workings of Eliot and the "midwife" Pound. Presenting Tiresias as an allencompassing central character serves to conceal the original fragmentariness of the poem but does little justice to its true character.

On stage, too, The Waste Land may seem to lend itself more to an ensemble performance rather than a presentation based on any Tiresias-centred account. The constant changes of figures in the poem due to the flitting between spaces and moments of time in the poem called for doubling of roles, thus allowing for each actor to play several different roles and making it far more of an ensemble piece than one dominated by a star or leading actor. This accorded with Eliot's belief, discussed in chapter one, that the group was more important than the individual. The lack of individuality was further stressed when we realised that there was no need for the characters to be defined or described, and we left them unnamed in rehearsals and unidentified for the audience. This is why I find the idea of performing The Waste Land as a one-person show, as in Fiona Shaw's case, less compelling.

There was a more traditionally choral element in the combined efforts of the disciples who circled the Sibyl in the epigraph. The fact that they moved together in a circle and jointly collapsed to the floor at the end of the scene provided a sense of a Chorus at work. This was in opposition to the Sibyl's generally solitary state 
condemned as she was to a lengthy, but meaningless existence. The contrast of the choral group as juxtaposed against the individual also helped to increase the tension in this scene by isolating and enclosing the solitary Sibyl.

Another place where the group element came to the fore was the line of workers in the "Unreal City" scene. Here, the chorus of workers were essentially in opposition to the narrator who stood apart, as it were, in his ability to observe the crowd travelling to work and to talk about it. The fact that these workers did everything together at the same time, for example, they walked behind each other and fixed their eyes to the front at the same time, connected them in a way that made them seem to belong to one integral unit or Chorus. Also the fact that they were all slaves to the same mechanical time created by the rhythm of the passage united them as a group.

Linked with the sense of the Chorus in the poem is the feeling that The Waste Land is a presentation of scenes from music-hall or vaudeville, both theatrical formats that made explicit use of choruses, albeit in a more musical than dramatic sense. The workshop production of the poem possessed a certain music-hall or vaudeville atmosphere since, as in these theatre forms, the actors often stepped up onto stage, presented their act and then vanished. There are different kinds of performers in the poem as in vaudeville or music-hall including the Oracular Sibyl, Madame Sosostris and the singers of the Wagnerian melodies.

The grand entry of Sosostris announced in the text makes this section seem like it is part of a music-hall act. The assistant or narrator introducing Sosostris sounded almost like the Master of Ceremonies of music-hall who describes a new act. Here, as in the case of the regular Master of Ceremonies, the narrator is given to satirical exaggeration in his description of Sosostris by calling her "the wisest woman in Europe":

Madame Sosostris, famous clairvoyante,

Had a bad cold, nevertheless

Is known to be the wisest woman in Europe

With a wicked pack of cards. (Complete 62, 11. 42-45)

The role of the music-hall Master of Ceremonies had its origin in the form of the Chairman "who sat at the front of the stage" in the early halls, the free-and-easies, 
and involved the audience by announcing to them directly the entry on stage of the star performers and encouraging applause (Kift 22). Kift provides us with this description of the music-hall Master of Ceremonies:

Attired in immaculate evening dress he, more than any other person in the early years, was responsible for giving their halls their tone and dignity. But the manner of his introductions and the language of his patter with its satirical exaggeration of middle-class and aristocratic speech patterns made it quite clear that he was parodying the members of those classes whose dress habits he was imitating. (22)

It is evident from the language used in The Waste Land that the narrator is parodying Sosostris, especially her inability to predict the onset of her own cold. The manner in which the actor playing the narrator involved the audience in his announcement of Sosostris' grand entry reminded one of the Master of Ceremonies in music-hall. While the presence of music-hall and vaudeville elements in parts of The Waste Land lends a theatrical air to them in performance it also increases the lyrical quality of the work thanks to the songs taken from the halls or from vaudeville. This is felt in the singing of the 'Shakespeharian Rag' in part two of the poem. The repeated 'O's of the song while bringing out the richness of vaudeville's ragtime songs also serve to build up the dramatic tension between the rich lady and her companion at this stage, thus interweaving the lyric and dramatic:

\section{But}

O O O O that Shakespeharian Rag -

It's so elegant

So intelligent (Complete 65, 11. 127-130)

Even after he moved more directly to the field of drama with Sweeney Agonistes, Eliot continued to use the music hall and vaudeville elements evident in The Waste Land. Thus, this aspect of the lyric-dramatic interaction in his work was a link across genres and across Eliot's career. 


\subsection{Conclusion}

By workshopping parts of the poem we discovered that dramatic elements often emerged from or existed alongside the lyric aspects of The Waste Land, and that it was when the lyrical was most strong in these scenes that the dramatic actually emerged more powerfully, as in the case of the hyacinth garden scene. This is an important aspect of Eliot's plays, as we shall see, in later chapters. It is when the lyric is most powerful in his plays that the drama is at its greatest height too. If we workshop more of the poem we may or may not find dramatic elements, which might aid the actors, or more instances of the lyric-dramatic interaction. For instance, there are more voices as we read through the poem as in the case of the lament of the Thames maidens in part three (Complete 70, 11. 292-305). However, these voices become few and far between the further we proceed through the poem. They are also less likely to interact with other voices to create a sense of dialogue as in the first two parts of the poem and often sound solely lyrical rather than having any dramatic qualities. The sense of dédoublement which exists in the hyacinth garden section and which is such an important part of the lyric-dramatic interaction in the poem, does not seem to recur.

The important thing to note from the workshop production is that enough of the dramatic exists in The Waste Land to cause what is, at some times, an exciting and, at other times, as Logenbach says, an uneasy interaction between the lyric and dramatic which leaves parts of the poem on the edge of drama (Logenbach 61). This provides a strong indication that Eliot was no longer happy in engaging with only poetry or dramatic poetry as a form after The Waste Land causing him to move more decisively towards writing poetic drama. Perhaps it is what led to Eliot telling Richard Aldington in a letter dated 15 November 1922 that The Waste Land was "a thing of the past" and that he was "now feeling toward a new form and style" (Letters 1: 786-787).

This shift points to a concrete culmination of his wish for poetic drama as Eliot enters the looking-glass, as it were, in order to explore the other side of his desire for a shared presence of the lyric and dramatic in his work. The straining for the dramatic in The Waste Land and earlier poems leads ultimately to the crossover moment. In this way, Eliot's experiments with dramatic elements in The Waste Land paved the way for his final approach to drama and the genesis of Sweeney Agonistes. 


\section{Chapter Four: Wanna Go Home, Baby? The Lyric in Sweeney Agonistes}

\subsection{Introduction}

After the publication of The Waste Land in 1922, Eliot turned explicitly to drama, more specifically to verse drama. While his career took a definite turn with the publication of 'Fragment of a Prologue' (1926) and 'Fragment of an Agon' (1927), later to become parts one and two respectively of Sweeney Agonistes, as we have seen, this turn was not unanticipated. While being an experiment in verse drama and a harbinger of the plays to come, the work also looks backward to Eliot's previous poetry containing, as it were, the past and the future, combined in the present moment. Where The Waste Land presents the lyric and dramatic together in poetic form Sweeney Agonistes involves the same lyric-dramatic interaction but within the overall framework of drama.

Significantly, some critics have found the text difficult to classify as either poetry or drama. For example, Jayne claims that Sweeney Agonistes is worth "the trouble" if "one regards it as [a] poem instead of as a play" (100). Part of the reason for the confusion over the genre resides in the fact that Eliot ultimately placed it in the section titled 'Unfinished Poems' in the Complete Poems and Plays even though it was clearly a play (Complete 8 , Worth 150). A more important reason for this genre confusion is that the piece bears a closer resemblance to Eliot's preceding poetry than it does to his later plays due to its intense lyricism and poetic rhythms. Scofield has this relationship in mind when he claims that Sweeney Agonistes has "an imagistic spareness and a rhythmic life which remind one of the earlier poems rather than the later dramas" (191). Lyricism here refers to the innate musicality of the work conveyed by the rhythm of the poetry and the presence of songs.

In this chapter I wish to examine the lyric elements in Sweeney Agonistes and explore how they emerge in the play. Through this I will demonstrate the centrality of this text to Eliot's near career-long focus on the interaction between the lyric and the dramatic. Despite its incomplete nature the play is situated at the peak of the 
lyric-dramatic curve in Eliot's literary oeuvre, not least because it is his first attempt to deal with the two elements in a genre different from poetry.

\subsection{Lyric elements in the play}

\section{The rhythm of jazz}

One of the most exciting features of Sweeney Agonistes is the pulsating rhythm of its lines. The vocal rhythms created by the repetition of its dialogue evoke a musical or lyrical style. Lines are shared by the characters in such a way that Eliot generates a strong sense of the lyrical in his dialogue just as he had created a strong sense of dramatic dialogue in The Waste Land. He does this by using rhythm, something he also did in The Waste Land as can be clearly seen in the pub scene in that poem (Complete 65-66). This element can be observed right at the start of part one when Doris and Dusty are busy discussing Pereira, the man who pays their rent:

DUSTY: How about Pereira?

DORIS: What about Pereira?

I don't care.

DUSTY: You don't care!

Who pays the rent?

DORIS: $\quad$ Yes he pays the rent

DUSTY: Well some men don't and some men do

Some men don't and you know who (Complete 115)

The rhythms, rhyme and the verbal interplay here result in a lyrical duet between the speakers, a feature which Eliot would continue to employ in The Family Reunion albeit in a less jazz-like manner. ${ }^{1}$ The number of feet in each half-line spoken by Doris or Dusty at the start is the same in every instance making it seem as if they are partners in a lyric duet (Chinitz, T.S. Eliot 111; Lightfoot 122). The rhythm is modified for the first time when Doris puts in an extra "yes" in "yes he pays the rent". As Chinitz points out, this appearance of an additional syllable in the line is an

\footnotetext{
${ }^{1}$ See chapter five for a discussion of lyric duets in The Family Reunion.
} 
element of syncopation in the text, a feature that we shall discuss a little later in this section (T.S. Eliot 112). Additionally, the presence of end-stopped lines as hinted by the use of full-stops, question-marks or exclamation marks, in all of the lines before Doris' "Yes he pays the rent" points to a similar pattern of pauses before each line is spoken so as to maintain the rhythm. The moment Doris moves into her syncopated line "Yes he pays the rent" the punctuation marks disappear and the line runs on into Dusty's "Well some men don't and some men do". This removal of the pause at the end of the line emphasizes the syncopated beat.

Eliot follows the pattern of using speakers in pairs to create more lyrical duets as the play proceeds. Klipstein and Krumpacker are the next set of speakers who appear on stage and they share their own lyrical exchanges in a similar manner to Doris and Dusty, complete with half-lines and improvisations:

KLIPSTEIN: How do you do

KRUMPACKER: How do you do

KLIPSTEIN: I'm very pleased to make your acquaintance

KRUMPACKER: Extremely pleased to become acquainted

(Complete 119)

Krumpacker, with his opening line, echoes and completes Klipstein's first line ("How do you do"), before he improvises on Klipstein's second line ("I'm very pleased to make your acquaintance") by using a similar, but slightly different order of words even while maintaining the same number of syllables as in the previous line.

The existence of musical rhythms in Sweeney Agonistes was not accidental but was, in fact, part of a conscious effort by Eliot to use the rhythms of jazz in his first verse drama as seen in a letter to Alfred Kreymborg dated 23rd August, 1923 where Eliot discussed the jazz rhythms of his planned play: "I am trying to get at a dominant rhythm and subordinated rythyms [sic] for the thing [Sweeney Agonistes] I expect it will be called jazz drama" (Letters 2: 192).

In January 1922, Eliot wrote to Pound saying he was reading Aristophanes almost certainly in preparation for Sweeney Agonistes. Pound replied: “Aristophanes probably depressing, and the native negro phoque melodies of Dixie more calculated to lift the ball-encumbered phallus of man [...]" (Letters 1: 630). Pound's crude reply 
directed Eliot towards the need to utilize the rhythms and music of AfricanAmericans in the early nineteenth century which later led to the blackface minstrel shows, ragtime and jazz. This response conceivably resulted in Eliot employing a "combination of the Greek classics and black dialect" (North 87) in Sweeney Agonistes making the text a "jazz Aristophanes" (Chinitz, T.S. Eliot 111). By using the phrase "black dialect" North refers to the jazz-style language and rhythms of the play, with all its inflections and improvisations essentially derived from the dialect and music of African-Americans of the late nineteenth and early twentieth centuries.

Eliot was conscious of the "black dialect" and ragtime, a forerunner of jazz, from his days as an adolescent in America. Jazz had reached England by January 1918, well before Sweeney Agonistes was conceived (Parsonage 3). Eliot, a keen dancer who kept in touch with the latest music and dance styles, would not have been unaware of the new developments while he was in England. Subsequently, he employed a jazz style in Sweeney Agonistes which can be observed all the way till the end of its second part.

In fact, the play can be viewed as being structured, partly at least, on a performance by the musicians of a jazz band of the 1920s, as described by Youngren: “A typical jazz performance of the 1920s will consist of a statement of the song by the full band, a series of solos improvised on the chord progressions of the song and perhaps (though not necessarily) making reference to its melody, and probably a concluding ensemble" (19). While this structure may not be evident in part one of the play, it sounds very close to what Eliot tried to achieve in the second part of the work where we have the two songs 'Under the Bamboo Tree' and 'My Little Island Girl' which are close to being a "statement of the song by the full band", followed by Sweeney's long solo speech and the final Chorus as a "concluding ensemble" (Complete 123-126).

One of the manifestations of the jazz rhythm in Sweeney Agonistes is the use of syncopation. Chinitz suggests, "Eliot's continually shifting patterns of strongly accented beats and weak intermediary syllables creates the effect of syncopation" (T. S. Eliot 112). ${ }^{2}$ The metre of the poetry and the rhythm of the drums provide the "regular underlying beat" while the speaker's words and inflections present the alterations and uneven patterns. The syncopation occurs through these inflections

\footnotetext{
${ }^{2}$ Shipton provides this concise definition of syncopation: "an alteration in the duration and accenting of notes that creates uneven patterns over a regular underlying beat" (31).
} 
which cause particular syllables to be stressed (Chinitz, T.S. Eliot 111). At the start of the play, the jazz-like use of inflections, syncopation and improvisation adds a highly-charged lyrical quality to the exchange between Doris and Dusty:

DORIS: I like Sam

DUSTY: $\quad I$ like Sam

Yes and Sam's a nice boy too.

He's a funny fellow

DORIS: $\quad$ He is a funny fellow

He's like a fellow once I knew.

He could make you laugh. (Complete 115)

A clear example of syncopation here is the expansion of "He's a funny fellow" as said by Dusty into "He is a funny fellow" when Doris takes up the line. Not only does the added syllable "is" create a syncopated moment which extends the melodic pattern over the underlying beat, its italicization points to the fact that this syncopated note, as it were, is stressed so as to bring out the jazz-like characteristic of the passage. Here, the absence of punctuation, specifically full-stops, at the end of each speaker's passage hints that their lines flow smoothly from one speaker to the next. The two speakers are like jazz players trying to use the words of the previous speaker to create their own improvised version of the language. As McNeilly maintains, "The characters are 'trading fours' like jazz musicians, bouncing thematic and rhythmic ideas, back and forth as they play (in this case, with language)" (42). ${ }^{3}$ It is this interplay of language that makes Sweeney Agonistes exciting. In fact the opening of the play resembles a jazz chase, "a competition in improvisation between two (or occasionally more than two) soloists who play in turn, taking inspiration from and trying to outplay each other" (New Grove 1: 423).

Eliot also used inflections in The Waste Land, specifically in the pub scene where the Cockney woman says: "You are a proper fool, I said" (Complete 66, 1. 162). While the use of inflections in the poem is restricted as compared to Sweeney

\footnotetext{
3 "In jazz to divide a chorus between or among solo players, so that each takes a phrase in turn. The length of phrases traded is usually four bars, but eight-bar and two-bar phrases and even single bars are also treated in this way; the players are said to "trade fours" ("eights," "twos," "ones") (New Grove 3: 775-776)
} 
Agonistes, the fact of its presence shows that Eliot was using this style before 1926 in his poetry.

This use of syncopation has links to jazz's predecessor, ragtime, which Eliot parodied in the 'Shakespeharian Rag' of The Waste Land (Complete 65, 1. 128). In fact, Sweeney Agonistes' original title Wanna Go Home, Baby? possesses all the flavour and rhythms of a jazz line with its easy rhythms and colloquial use of language (C. Smith 51; Crawford 176). The improvisation of language continues in the passage with Sweeney and Doris at the start of part two:

SWEENEY: $\quad$ I'll carry you off

To a cannibal isle.

DORIS: You'll be the cannibal!

SWEENEY: You'll be the missionary!

You'll be my little seven stone missionary!

I'll gobble you up. I'll be the cannibal.

DORIS: You'll carry me off? To a cannibal isle?

SWEENEY: I'll be the cannibal.

DORIS: $\quad$ I'll be the missionary.

I'll convert you!

SWEENEY: I'll convert you!

Into a stew.

DORIS: You wouldn't eat me!

SWEENEY: Yes, I'd eat you!

In a nice little, white little, soft little, tender little,

Juicy little, right little, missionary stew. (Complete 121)

More telling than the improvisations on the themes of the missionary and the cannibal in this sequence is the adlibbing that each character indulges in. There is an exciting interaction of words between the speakers wherein they start to parallel, echo and improvise on what the other says in a style very much like a jazz duet. Thus, when Doris says: "You'll be the cannibal", Sweeney at first echoes her rhythmically by using the same number of syllables in his response and the same idea when he says "I'll be the cannibal." However, he then 'improvises' by stretching the rhythm altogether while speaking a much longer next line: "You'll be my little 
seven stone missionary!" The use of exclamation marks at the end of each of these three lines and the appearance of the same words at the start of each line ("You'll be the") ensures the maintenance of an overall rhythm within which the characters can improvise on their melodic notes.

The cannibal theme from the above passage introduces the idea of the 'primitive' in the play which is not unexpected given Eliot's early interest in primitivism. This belief in primitivism is at the heart of the rhythm in Sweeney Agonistes and has partly to do with the use of jazz in the play. Chinitz points to the employment of jazz rhythms as a realization of Eliot's quest for a new drama based on modern rhythmic patterns. However, he also refers to the paradoxical idea that jazz "was supposed to be an importation of savage ritual, a transplantation of "jungle music" (Chinitz, T.S. Eliot 111). Jazz's hybrid quality is evident from the fact that it contains both European and African elements (Youngren 20). This double-sided nature of jazz prodded Eliot to integrate a 'primitive element with a more modern style in his drama.

By using jazz rhythms in the dialogue of Sweeney Agonistes Eliot took us back to a 'primitive' time when the lyric and dramatic existed together in ritual. The text follows the structural pattern of Aristophanic comedy which arose in ritual. ${ }^{4}$ However, its 'primitive' nature emerges through the use of jazz rhythms and music.

The origins of jazz have been linked to the sacred ring ritual of the Yoruba tribe in western Africa during which community members would sing and dance in a ring while being possessed by deities (Floyd 10). ${ }^{5}$ The "hoo has" which appear towards the end of part two of Eliot's text could be interpreted as an echo of the Yoruba ring shout (Floyd 13, Complete 125-126). One of the features of what Floyd calls the "slave culture" in nineteenth century America involves "wordless sounds that are sometimes used for their own value rather than for communication of verbal meaning" (13). The "hoo has" are basically such wordless sounds. Freedman discovers similar sounds, which he says are common in jazz, in other parts of Sweeney Agonistes, such as when the telephone rings (423):

\footnotetext{
${ }^{4}$ See Crawford 162-64; C. Smith 63-67 and Sidnell 91-92.

5 "In these rituals, possession is brought on by drumming, chanting, singing, and persistent and energetic dance in the form of mass dancing, team dancing, small-group dancing (two, three, or four people), and ring dancing. In many African societies, this dancing took place in the dance ring [...]" (Floyd 9).
} 
TELEPHONE: Ting a ling ling

Ting a ling ling (Complete 116)

Eliot's employment of these rhythms in his drama was not without precedent. Dadaist writer Tristan Tzara in his play La Première Aventure Céleste de M. Antipyrine (The First Celestial Adventure of Mr. Antipyrine, 1916) provides his audience with this amazing collection of wordless sounds through a Chorus comprising four characters:

Mr. CRICRI

Mr. BLEUBLEU

PIPI

Mr. ANTIPYRINE zdranga zdranga zdranga zdranga di di di di di di di di zoumbaï zoumbaï zoumbaï zoumbaï dzi dzi dzi dzi dzi dzi dzi dzi

(Tzara 79)

Thus Dada, a counter-realistic theatre movement in Europe, had already used ideas similar to what Eliot was trying with Sweeney Agonistes.

In the final chorus of Sweeney Agonistes, Wauchope, Horsfall, Klipstein and Krumpacker chant together. Here, the dream as nightmare, bearing with it 'primitive' fears of a violent demise, is juxtaposed against the modern criminal's fear of death by the hangman's noose. The jazz rhythm of the chanting in this scene increases the tension of the dramatic moment leading ultimately to frenzied knocking as the Chorus continues with a graphic description of the nightmare:

Hoo hoo hoo

You dreamt you waked up at seven o'clock and it's foggy and it's damp and it's dawn and it's dark And you wait for a knock and the turning of a lock for you know the hangman's waiting for you.

And perhaps you're alive

And perhaps you're dead

Hoo ha ha 
Hoo ha ha

Hoo

Hoo

Hoo

KNOCK KNOCK KNOCK

KNOCK KNOCK KNOCK

KNOCK

KNOCK

KNOCK (Complete 126)

The knocking on the door, which should ordinarily be a stage direction in a play, becomes part of the language of the Chorus. Jones observes, "like the ringing of the telephone $[\ldots]$ the knocks are used as a contribution to the rhythm of the play and are, therefore, included in the patter of the verse" (36). The knocking, in fact, maintains a similar rhythm to the repeated sounds "hoo" and "ha" repeating themselves in patterns of three initially before finishing with three separate knocks. DuPlessis claims that the "hoo" used here is a word meant to scare a "white" audience with its 'primitive' nature (105). Similarly, the use of the word "ha" could be seen to refer to laughter and infuses the Chorus with an element of fear. This usage of onomatopoeic sounds lends a 'primitive' air to this part of the play while increasing the lyrical quality of the passage. In fact, this utilization of onomatopoeic sounds echoes similar usage by Eliot in The Waste Land, especially in the bird song of 'The Fire Sermon' which goes “Twit twit twit / Jug jug jug jug jug jug” (Complete 67, 11. 203-204).

The sound of the spoken knocking in Sweeney Agonistes is more significant and alarming than just the meaning of the word. This is why Eliot employs human voices to speak or chant the word "KNOCK" rather than putting down stage directions that call for actual knocking. This emphasis on sound points to a lyrical quality and the importance of rhythm in the work. As McNeilly observes, Eliot's text is a "form of utterance that has pulverized articulation and reduced language back to a thudding pulse" (40).

Eliot's request for drums to be played throughout the play's performance highlights the work's “thudding pulse". In his 1933 letter to Hallie Flanagan, prior to the first staging of Sweeney Agonistes at Vassar, Eliot claimed that he intended "the 
whole play to be accompanied by light drum taps to accentuate the beats" (Flanagan 83). This use of drumbeats during performance was not unique to Eliot and was part of the project for a revival of verse drama in modern times having been employed previously by Yeats in his verse plays Four Plays for Dancers (1916-1920) (see Yeats 297; Worth 154). Drumbeats are also called for in Auden's The Dance of Death (1933), which received its premiere alongside the London première of Sweeney Agonistes in 1934. In Auden's text the Announcer actually tells the Chorus to strike the drums:

ANNOUNCER. Get ready, your instructor comes

Stand up at ease, and beat the drums. (Auden 85)

While Eliot does not really write the drumbeats into his performance the way Auden does, by asking for drumbeats to accompany the play Eliot sought to highlight the rhythmic quality apparent in the lines of the work and stress the poetic metre of the line. However, the use of drums also implies the steady presence of the firm beat that, as Youngren says, is "kept by the drums and the other rhythm instruments" in jazz music (17). Above and over this steady beat the audience of Sweeney Agonistes can make out the syncopation of the jazz melody that is present in the dialogue.

The use of drums for performances of the play would not be effective without the lyric rhythm and inherent musicality of the lines. In this regard, it is interesting that Sweeney Agonistes has often been performed with accompanying music since this reveals the intrinsic lyricism of the text. One of the important performances in this respect was Peter Wood's revival of Sweeney Agonistes at the 'Homage to T.S. Eliot' in June 1965 at the Globe where the play was performed with jazz accompaniment composed by John Dankworth (Malamud 37). It was also converted into a chamber opera by Richard Winslow and performed at Columbia University in 1953 (G. Smith 113). ${ }^{6}$

\footnotetext{
${ }^{6}$ I will not go into an extensive discussion of past performances of Sweeney Agonistes. For an extensive record of the same see Malamud 1992.
} 


\section{Backchat and Minstrelsy}

Rhythm in Sweeney Agonistes is often governed by the flow of the language in the short, and sharp, exchanges between the characters, that is, backchat. The use of backchat can be traced back to the plays of Seneca in ancient Rome as described by Eliot:

Several scholars, Butler in particular, have called attention to a trick of Seneca of repeating one word of a phrase in the next phrase, especially in stichomythia, where the sentence of one speaker is caught up and twisted by the next. This was an effective stage trick, but it is something more; it is the crossing of one rhythm pattern with another. (Selected 88)

Such stichomythia, essentially a less colloquial word for backchat, allowed Eliot to employ verse rhythms within an overall dramatic structure in Sweeney Agonistes. Chinitz provides us an example of backchat from the interchange between Krumpacker and Klipstein which begins after Doris asks the pair whether they like London (T.S. Eliot 109):

KRUMPACKER: Do we like London? do we like London! Do we like London!! Eh what Klip?

\section{KLIPSTEIN: $\quad$ Say, Miss - er - uh - London's swell. We like London fine. (Complete 119)}

As Grover Smith points out, Eliot here employs "the device of 'bouncing' a line from one speaker to the next" which is an essential element of backchat (115). Eliot achieves this effect by using a question mark at the end of the first speaker's lines (“Eh what Klip?") allowing the second speaker to play around with the words of the former. This brings us close to a definition of stichomythia or backchat in the theatre which is characterised by "rhetorical repetition or taking up of the opponent's words" (OED online). Thus it follows that Klipstein uses Krumpacker's words "Do we like London? do we like London!" and turns them around with his improvised response 
to it: "We like London fine." The use of backchat in Sweeney Agonistes complements and sustains its jazz rhythm. Even as Klipstein picks up and reworks Krumpacker's original line, he adds a faltering "er - uh", two syllables with no meaning, that sound like jazz scatting and help maintain the overall rhythm of the line. ${ }^{7}$ Thus, while Klipstein struggles to respond to Krumpacker's question, he paradoxically succeeds in maintaining the rhythm created by the latter's lines before turning the original question around into a response.

Eliot displayed his awareness of the use of backchat in the theatre in Old Possum's Book of Practical Cats (1939) where, appropriately, it is Gus, the theatre cat, who is an expert in backchat: "I'd extemporize back-chat, I knew how to gag, / And I knew how to let the cat out of the bag" (Complete 228, 11. 23-24).

In his critical writing, Eliot stressed backchat's role in the theatre by linking it to Senecan drama and to minstrelsy: "The characters in a play of Seneca behave more like members of a minstrel troupe sitting in a semicircle, rising in turn each to do his 'number', or varying their recitations by a song or a little back-chat" (Selected 69). Eliot attempted this minstrel-style presentation in Sweeney Agonistes. His linkage of backchat to minstrelsy provides us with a clue to the next place we should look for the interaction of the lyric and the dramatic in the play. The fact that Eliot used the minstrel show as a basis for his work is evident in the alternative title for Sweeney Agonistes: 'Fragment of a Comic Minstrelsy' provided in the typescript (Sidnell 263; Chinitz, T.S. Eliot 112). The play employs the minstrel tradition of midnineteenth century America as a framework for its characters, dialogue and music. In fact, a production of Sweeney Agonistes at the Schloss Leopoldskron in Salzburg in 1949 featured Snow and Swarts as blackface minstrels (E. Bentley 390-391). ${ }^{8}$

Toll describes the early minstrel show as "unabashedly popular in appeal, housed in its own show places, performed by middling Americans, focused on humble characters, and dominated by earthy, vital, song, dance, and humor" (25).

\footnotetext{
${ }^{7}$ Scatting in jazz involves the use of wordless sounds to provide an improvisation upon the regular rhythm and melody of the music. While Klipstein's line does not change the rhythm of the line it definitely changes the "melody of the music". Jazz scatting was famously made popular by Louis Armstrong's 1926 rendition of Boyd Atkin's song "Heebies Jeebies" when Armstrong claimed to have dropped the paper containing the lyrics causing him to scat-sing during the studio recording in Chicago (B. Edwards 618-619). The sheet music for the song includes a transcription of Armstrong's improvisation: "Skeep! Skipe! Skoop! Brip Ber Breep bar la bah” (B. Edwards 618, n 1).

${ }^{8}$ Blackface is today, of course, justly considered to be politically incorrect and racially demeaning.
} 
This is what Eliot strives for in Sweeney Agonistes when he brings together characters like Doris, Dusty and Sweeney in a performance that is "earthy" and "vital" and contains "song, dance, and humor". Commenting on the features of a minstrel show, Toll states "Each act - song, dance, joke, or skit - was a selfcontained performance that strived to be a highlight of the show" (34). We witness several self-contained performances in part two of Sweeney Agonistes, where there are the two songs sung by different groups of actors. 'Under the Bamboo Tree' is presumably sung by Wauchope and Horsfall while Swarts and Snow accompany them on the tambourine and the bones in a kind of minstrel show quartet (Complete 122). Similarly Klipstein and Krumpacker seem to be the ones that sing 'My Little Island Girl' while Swarts and Snow provide accompaniment (Complete 123). There is no real sense of a plot working in the play here, and although there are similar themes linked up to primitivism in both songs and the preceding dialogue, the play could have easily done without the songs and not lost anything with regard to plot itself. In this sense, it approaches music-hall, vaudeville or revue as one performance follows the next without necessarily being connected by plot.

Minstrelsy, which arrived in the music-halls of Victorian England in the midnineteenth century, was part of a popular, though admittedly racist, alternative to realist theatre at the time (Pickering 89-90). As such it was an important part of Eliot's attempt to repudiate realistic drama. His use of images from minstrelsy goes back as far as his early poetry and is a point of connection between his poetry and drama (see 'Suite Clownesque', Inventions 35, 11. 13-14: "Here let a clownesque be sounded / on the sandboard and bones).

Eliot borrowed the structure of Sweeney Agonistes from the first part of the traditional minstrel format where a character called Mr. Interlocutor served a function similar to the Master of Ceremonies of English music-hall while remaining at the centre of a semicircle of performers (Chinitz, T.S. Eliot 113). At opposite ends of this semicircle sat the endmen, Tambo and Bones. ${ }^{9}$ Chinitz suggests that Sweeney plays the role of Mr Interlocutor in Eliot's work while we already know that Swarts plays Tambo and Snow plays Bones from the text itself: "SONG BY WAUCHOPE AND HORSFALL. SWARTS AS TAMBO, SNOW AS BONES" (Chinitz, T.S. Eliot 113; Complete 122). Tambo and Bones are named for the

\footnotetext{
${ }^{9}$ See Hatch 94; Toll 54; Pickering 75 and Freedman 429 for more on this. For a photograph of a performer playing Bones on stage see Engle in the pages following page 84
} 
instruments they bear with them on stage, a tambourine and set of bones respectively (Chinitz, T.S. Eliot 113; Hatch 94). Thus we can imagine that Swarts would hold and play a tambourine on stage during the performance of the songs in the text and Snow would strike upon the set of bones he holds in his hand to provide a rhythm to the music on stage.

Another feature from minstrel shows which Chinitz uncovers in Sweeney Agonistes is the stump speech or comic monologue in the olio or the second part of the show (T.S. Eliot 113). However, before the stump speech there was the variety section in minstrel shows, part of the olio, when audiences were traditionally given a "wide range of entertainment" including "song and dance men, acrobats, men playing combs" (Toll 55). This section is present in Sweeney Agonistes as well and it includes the two songs 'Under the Bamboo Tree' and 'My Little Island Girl', sung just a few moments before Sweeney begins his stump speech. Only a couple of lines of Doris' dialogue separate the two songs (Complete 122-23).

This section is a lot like the variety show of music-hall. Kelly points out that the "syncopation of dialogue and choral songs, as well as the comic treatment of serious themes, shows the direct influence of the music-hall on Eliot's dramatic rhythm" (170). These minstrel and music-hall elements bring the lyric in the work to a highpoint given that there are two songs placed almost back-to-back at this stage. The fact that one of these songs ('Under the Bamboo Tree') was first performed as part of revue and that both songs are framed in the older minstrel tradition preserves the theatrical elements in them as well (Complete 122).

The stump speech was usually delivered by one of the endmen, not by $\mathrm{Mr}$. Interlocutor, and almost always ended with the speaker falling off the podium after the speech (Toll 55-56).It is however, Sweeney as the Interlocutor, who commences his stump speech:

SWEENEY: Well here again that don't apply

But I've gotta use words when I talk to you.

But here's what I was going to say. (Complete 125)

Toll reveals that "the stump speakers regularly got laughs by combining the physical comedy of endmen with their verbal pomposity" (56). Eliot improvises on the stump speech convention by shifting the speech from the endmen to the Interlocutor 
(Sweeney). We are not sure whether Sweeney falls at the end of his speech in the manner of the Interlocutor since Eliot has not provided any stage direction in this regard. Sweeney's lack of desire to use words may be a verbal parallel to the physical fall that would have attended him had he actually been part of a minstrel show. Through this Eliot displays both his reliance on lyrical forms and his desire to create a new kind of stage experience for his audience.

"Do you want to flirt with me?" Songs in the play

Commenting on the inclusion of popular songs in Sweeney Agonistes Jones observes: "In the development of Eliot's art Sweeney Agonistes is perhaps most important as an experiment in the introduction of contemporary rhythms and diction into poetic drama [...] Eliot parodies the popular song of the jazz era" (28).

The jazz-like improvisations which begin in the dialogue of Sweeney Agonistes continue through the performance of the two songs 'Under the Bamboo Tree' and 'My Little Island Girl' both of which describe life on a tropical isle, thus linking them to the theme and melody of the 'cannibal isle' duet introduced by Sweeney and Doris at the start of part two (Complete 122-23).

As in The Waste Land with its 'Shakespeherean Rag', Eliot used ragtime music in Sweeney Agonistes. 'Under the Bamboo Tree', an improvised version of which appears in Sweeney Agonistes, was lyricist James Weldon Johnson and composers Bob Cole and J. Rosamund Johnson's version of an anti-coon song, one in which love between Africans is portrayed in a less condescending manner as compared to regular coon songs since the emotions of the lover are presented in a more refined way (see Chinitz, T.S. Eliot 116). ${ }^{10}$

The African-American composing team comprising the Johnson brothers and Cole were path-breakers in the field of American music and musicals. Rosamund Johnson and Cole were not only composers but also sang and acted in their own musicals. Cole maintained that:

\footnotetext{
${ }^{10}$ The first vehicle of vocal ragtime music, the coon song, was racist in nature, portraying African Americans in a degrading light. Often performed as part of vaudeville, it was also connected to the minstrel songs of nineteenth century America (Morath 33-34). Coon songs normally poked fun at African American life while employing the dialect of the race (Abbott 11).
} 
What we aim to do [...] is evolve a type of music that will have all that is distinct in the old Negro music and yet which shall be sophisticated enough to appeal to the cultured musician. We want the Negro spirit - its warmth and originality - to color our music; we want to retain its marked rhythms, but we are trying to get away from the minor strain that used to dominate it. (Qtd. in Woll 21)

Cole's statement brings to light the tendency of the West to undermine Africa's traditional music culture by dismissing it as 'primitive', even while manipulating its rhythms to come up with a music that would entertain them in modern times. $\mathrm{He}$ wished to retain the "warmth and originality" of the older music while blending it with a modern, more "sophisticated" musical style. Cole was perhaps the most important influence in the movement of minstrel music, through ragtime, into modern jazz largely free from the shackles of racism that had marred both minstrelsy and ragtime.

For Eliot, going back to Africa would mean returning, Conrad-like, to the cradle of humankind, to a time when ritual was all-encompassing. He was, in essence, attempting something similar, yet different to what Cole attempted quite successfully. While Cole sought to combine traditional African music as used and modified by the 'slaves' with contemporary ragtime to point forward to jazz, Eliot utilised the modern music of ragtime and jazz to turn backwards towards what he believed was the 'primitive'. Cole wrote modern music that included 'primitive' beats which finally ended up on a modern-day stage as part of musicals or vaudeville. Eliot used this same music and its rhythms to turn back towards a 'primitive' time when the lyric and dramatic were part of the same thing through ritual.

Eliot employed what was, for his time, a modern song, a popular hit of early ragtime, 'Under the Bamboo Tree' (1902), in Sweeney Agonistes. The song was first sung by Marie Cahill as part of her revue show Sally in our Alley in 1902 (Ewen 173). Rosamund Johnson and Cole later incorporated it into their popular two-man vaudeville show (Woll 28). 
As part of revue and vaudeville the song would have involved dance as well. Dance would be important to a performance of the song in Sweeney Agonistes too. ${ }^{11}$ While Wauchope and Horsfall sing their lyrics they would also be, ideally, dancing to the tune, while Swarts plays on his tambourine and Snow strikes the bones together. In fact, Swarts, as Tambo of the minstrel show, would be "expected to go through wild and grotesque maneuvers for the benefit of the audience, while performing on his instrument" (Wittke 140). This mix of music and dance points to the interaction between the lyric and the dramatic in Sweeney Agonistes.

Eliot removes the song from its more modern vaudeville and revue tradition and relocates it in a minstrel show context which allows it to retain links to the earlier, racist coon songs. More importantly, for this thesis, it establishes a stronger tie to the theatre based on the play's link to an earlier performance format. Moreover, Eliot's revision of 'Under the Bamboo Tree' trades a more refined sense of love, romance, and Romanticism for a more guttural, 'primitive' experience. Johnson's lyrics are as follows:

If you lak-a-me, lak I lak-a-you,

And we lak-a-both the same,

I lak-a say, this very day,

I lak-a-change your name;

'Cause I love-a-you and love-a-you true

And if you a love-a-me,

One live as two,

Two live as one

Under the bam-boo tree. (Cole 333)

Eliot, however, drops the first six lines of the refrain, all the bits about liking and loving, and retains only an improvised version of the ending in Sweeney Agonistes:

\footnotetext{
${ }^{11}$ In the film Meet Me in St. Louis (1944), Judy Garland and Margaret O'Brien perform a short songand-dance item for a home gathering using 'Under the Bamboo Tree' as their song. In the film, the two female performers wear minstrel show-type hats and carry canes while performing their songand-dance routine, while a male actor, seated in the background, plays upon an instrument. The musical film and the original book of stories by Sally Benson on which it is based are both set in St. Louis, the ragtime capital of America in 1904, the year of the St. Louis World Fair where Eliot heard 'Under the Bamboo Tree' being performed when he was in his teens (North 10).
} 
Under the bamboo

Bamboo bamboo

Under the Bamboo Tree

Two live as one

One live as two

Two live as three $[\ldots]$ (Complete 122)

By discarding the romantic element from the original lyrics, Eliot provides his singers with baser motives for their passion and shifts the poem into an even more 'primitive' mode. This is further indicated by the primeval breakdown of language in the song as at the end of the play:

Under the bam

Under the boo

Under the Bamboo Tree. (Complete 122)

North compares the "bam" and "boo" of the word "bamboo", broken into two seemingly meaningless syllables by Eliot in the song, to the "Ha" and "hoo" in the final chorus of the play, while Freedman views the breaking up of words here as part of the creation of a jazz rhythm in the play (North 89; Freedman 419; Complete 126).

Additionally, the song makes use of stereotypical ideas about 'primitive' cultures. The Gauguin maids of Eliot's version of 'Under the Bamboo Tree' indicate a different kind of primitivism from the one used by Cole in his song, one that sought to describe an island culture instead of a jungle located deep in the heart of Africa and reminds us of Eliot's adolescent stories which were also set in the South Pacific:

Where the breadfruit fall

And the penguin call

And the sound is the sound of the sea

Under the bam

Under the boo

Under the bamboo tree.

Where the Gauguin maids 
In the banyan shades

Wear palmleaf drapery (Complete 122)

Eliot presents the scenery of the Pacific tropical isles in a very conventional manner in his next song which starts with the line "My Little Island Girl" (Complete 123). This song seems to be set in the West given that it tells of the couple leaving behind trains, which points to a discarding of the modern world for something more 'primitive'. Given that trains were mostly restricted to Europe at that time, the song places the singer in a Western space or on a Western stage, most likely British music-hall. Snow and Swarts still play Tambo and Bones from the minstrel show, located now within the context of music-hall. This has historical precedence as the minstrel show was introduced from America into British music-hall in the nineteenth century:

\title{
SONG BY KLIPSTEIN AND KRUMPACKER SNOW AND SWARTS AS BEFORE
}

\author{
My little island girl \\ My little island girl \\ I'm going to stay with you \\ And we wont worry what to do [sic] \\ We won't have to catch any trains \\ And we won't go home when it rains (Complete 123)
}

Eliot's use of a song from the coon and anti-coon traditions in Sweeney Agonistes did not come out of the blue. He had already tried his hand at something similar in the draft versions of The Waste Land where he planned to use lines from a 1904 coon song 'By the Watermelon Vine (Lindy Lou)' by Thomas S. Allen (Waste Land Facsimile 5; Chinitz, 'In the Shadows' 451). He also used words from another song of the period, Mae Sloane's 'My Evaline', in the same section of the draft (Waste Land Facsimile 5). These attempts were subsequently discarded. Chinitz tells us that 'My Evaline' was part of a 1901 vaudeville-minstrel act. If Eliot had used these songs it would have placed The Waste Land "in a racialized, popular, American 
context" which, Chinitz believes, except for the bit on the 'Shakespeharian Rag', barely survives in the final version of the poem ('In the Shadows' 452).

Ultimately, The Waste Land retained four musical pieces that were borrowed directly from different sources - the snatches of Wagnerian music from Tristan und Isolde (Complete 61-62, 11. 31-34 and 62, 1. 42) and from the Rhine maiden's song in Götterdämmerung (3.1, 148-149; Complete 70, 11. 290-1), the take-off on the 'Shakespearian Rag' $(65,1.128)$ and the ballad or ragtime song of Mrs. Porter (67, 11. 199-201). These songs not only enhance the quality of the lyric-dramatic interaction in The Waste Land but are also paralleled and improved upon in some way by the songs and rhythms in Sweeney Agonistes. If Eliot directly borrowed whole lines from Wagner in The Waste Land, in Sweeney Agonistes he improvised the rhythmic pattern of the 'Nightmare Song' in Gilbert and Sullivan's comic opera Iolanthe (1882) to develop his own version of a nightmare chorus (see Complete 125; Gilbert 289). Similarly, Eliot's take-off on the vaudevillian song 'Shakespearian Rag' in The Waste Land is paralleled by his 'improvisation' of 'Under the Bamboo Tree' in Sweeney Agonistes. The play contains a greater proportion of ragtime and other musical patterns as compared to The Waste Land, and even has lyrics for a song perhaps written by Eliot himself ('My Little Island Girl').

In a sense, then, what Eliot did not attempt so whole-heartedly in The Waste Land: the use of improvisations of popular songs from music-hall or vaudeville integrated into the text, he tried for more completely in Sweeney Agonistes. He was close to achieving with Sweeney Agonistes what he sought for in lyrical drama as a whole. The coon song/minstrel show/vaudeville act is at the core of the play, both lyrically and dramatically, and it fuses these two elements perhaps more effectively than in the few musical moments of The Waste Land. This is even more clearly the case since, in Sweeney Agonistes, the songs are presented in a theatrical context, while the same cannot be said of The Waste Land.

The final chorus in Sweeney Agonistes is based on 'The Nightmare Song' from Iolanthe (DuPlessis 97; Worth 153). Eliot's final chorus begins:

When you're alone in the middle of the night and you wake in a sweat and a hell of a fright

When you're alone in the middle of the bed and you wake like someone hit you in the head 
You've had a cream of a nightmare dream and you've got the hoo-ha's coming to you. (Complete 125)

By contrast, Gilbert's Lord Chancellor begins his 'Nightmare Song' thus in the second act of Iolanthe:

LORD CH.: When you're lying awake with a dismal headache, and repose is taboo'd by anxiety,

I conceive you may use any language you choose to indulge in, without impropriety;

For your brain is on fire - the bedclothes conspire of usual slumber to plunder you [...] (Gilbert 289)

Eliot's Chorus with its image of waking in bed in a "sweat and a hell of a fright" is more frightening than the Lord Chancellor's presentation of a "dismal headache" and a "repose [...] taboo'd by anxiety". The inversion of syntax in the line "usual slumber to plunder you" from the Lord Chancellor's song removes any hint of scariness that might have existed. This element of fear ensures the retention of a primitive element in Sweeney Agonistes.

Eliot's use of the patter song style of the Gilbert and Sullivan work undoubtedly adds to the lyrical quality of his play, while his recalling of Savoy opera allows it to retain some of its theatrical context. His use of operatic rhythms and of music from revue and vaudeville points to a mixing of music and drama which brings his work closer to the melodramatic form.

\section{Melodrama: Bringing together music and drama}

An aspect of Sweeney Agonistes which points to the working of the lyric-dramatic interaction is the use of the melodramatic style as revealed by its subtitle: 'Fragments of an Aristophanic melodrama' (Complete 115). The word 'melodrama' is a combination of 'melos', meaning song, and drama (Abrams, Glossary 110). Ancient Greek dramatists, including Aristophanes (447-386 BC), who Eliot sought to use as a model for Sweeney Agonistes, employed music as "an integral part" of their plays 
(Brockett 27). This music was especially heard in the choral singing and dancing of these plays which was an inheritance from the Dionysian rituals that preceded drama (Solomis 48).

Eliot's presentation of music and dance within the minstrelsy, music-hall and operatic traditions in Sweeney Agonistes is a modern equivalent of the Dionysian ritual used by Aristophanes in his plays. Eliot's need to create the sense of a modern ritual which would parallel those used in ancient Greek melodrama is one of the factors that may have caused him to introduce musical elements in the play.

He also hoped to imitate the ancient Greek playwrights through the use of masks for Sweeney Agonistes (see Brockett 29). In his letter to Flanagan, Eliot demanded that the "characters ought to wear masks; the ones wearing old masks ought to give the impression of being young persons (as actors) and vice versa" (Flanagan 83). Flanagan ignored Eliot's advice on the use of masks for her production at Vassar (J. Bentley 137). However, in Rupert Doone's production of the play by the Group Theatre in 1934 all the characters, except for Sweeney, wore halfmasks (Sidnell 104-105). This use of masks recreates a sense of the ancient Greek Chorus thus returning the text to an essentially traditional melodramatic form. Jayne, in fact, suggests that the six men other than Sweeney in part two of the play act as a kind of Greek Chorus as is evident through the songs performed by four of these six at a time and the concluding ensemble where Wauchope, Horsfall, Klipstein and Krumpacker get together (Complete 125; Jayne 112).

In Sweeney Agonistes Eliot sought to draw on a plot which involved the more modern melodramatic features that could be seen on the nineteenth century Victorian stage. The prime feature, in this regard, was the handling of the theme of crime, the gory description by Sweeney of the girl murdered in her bath (Complete 124) and the planned murder and 'resurrection' of Mrs. Porter which Eliot never realized in the incomplete text (see Crawford 164). The design for the resurrection in Sweeney Agonistes was an attempt by Eliot to parallel Frazer's description of the death and resurrection of the 'primitive' Egyptian god, Osiris, by using a corrupted, modern figure, Mrs. Porter, in place of the ancient god (Frazer 493). This plan to recreate ritual, although not executed, was perhaps part of the reason for the increased use of music and choral arrangements on the stage in the play. This ritualistic element was also visible in The Waste Land production in the Sibyl scene which called for choral arrangements. The death and resurrection motif has parallels with the melodrama of 
the Victorian stage including the case of the character of the rather infamous barber, Sweeney Todd, in George Dibdin Pitt's melodrama The String of Pearls (1847). In Pitt's work, which has its origins in the Victorian penny-dreadful, the mariner Mark Ingestrie survives Sweeney Todd's attempt to murder him and returns to haunt Sweeney at the latter's trial. Sweeney, who believes that Ingestrie is dead and has now been resurrected in order to accuse him in front of the judge, breaks down and reveals his guilt at play's end:

SWEENEY. Ha, ha! 'tis useless to deny my guilt; the very dead rise from their cerements to prove Sweeney Todd a murderer!

(Pitt 262)

Eliot's play does not merely reflect the Sweeney Todd story in attempting to be a melodrama but also borrows imagery from a real life crime that happened just over a decade before Sweeney Agonistes was originally written. This was the story of the American homeopathic doctor H. H. Crippen who had poisoned and cut up his wife, the small-time music-hall performer Belle Elmore, in England in 1910, a crime for which he was later hanged (Baker 201-204). Eliot's Sweeney in Sweeney Agonistes refers to this heinous crime when he says that he knew a man who "did a girl in" and that he had preserved her body in a "gallon of lysol in a bath" (Complete 124). This was similar to, yet different from, what Crippen had done when he dissolved part of his wife's body in a bathtub filled with acid. The theme of murder was very much part of Victorian melodrama, as evident in The String of Pearls, and it was part of the reason for the presence of the same in Sweeney Agonistes.

Given its added attraction as a story of the murder of a music-hall performer Eliot could not refrain from referring, if only obliquely, to the Dr. Crippen episode in his work, thus effectively mixing two important elements of Victorian theatre: music-hall and melodrama. In fact, English music-halls resounded to the sounds of a song penned to celebrate the arrest of Crippen and his lover Ethel le Neve following their dramatic flight by steamship to Quebec:

Inspector Dew is waiting, Miss le Neve.

Inspector Dew is waiting, Miss le Neve,

But Miss le Neve is sitting 
On the knee of Dr Crippen

Boarded on the Montrose

Dressed in boy's clothes.

Oh! Miss le Neve! (Baker 203)

So obsessed was Eliot with the Crippen story that he chose to dress up as the villainous doctor when he attended a fancy-dress party in 1939 just a few months after Vivienne Eliot was admitted to an asylum for life! (Gordon 288).

The ending of part two of Sweeney Agonistes refers to a death by hanging for a murder (something which happened to Dr. Crippen), and employs knocks upon the door which could either signify policemen coming to arrest Sweeney for murder or the inevitable knocking of Death (Complete 126). This ending is melodramatic, in the Victorian sense of the word, in that it has a feeling of suspense and deals with crime, a preoccupation of Victorian society. It should also ideally lead on to another exciting scene not the insipid finish written out by Eliot to Flanagan (See Flanagan 83-84). In fact, Rupert Doone's 1934 production of Sweeney Agonistes in London ended with Sweeney chasing Doris round a table razor in hand. This was followed by the sound of a police whistle, a scream by Doris and the knocking at the door (Sidnell 106). Doone thus situated the play within the conventions of melodrama on the stage in terms of its elements of surprise and possible crime. While Doone's efforts may be said to be a directorial extrapolation of the text, it had its basis in the melodramatic aspects of the work which also allowed it to retain many of its lyrical aspects.

\subsection{The success or failure of Sweeney Agonistes, and its incomplete status}

Critical attacks on Sweeney Agonistes over the years have largely focused on its incomplete nature and its music-hall style. Grover Smith slams what he calls "the farcical music-hall style" of 'Fragment of an Agon' as an "improper vehicle” for the "serious theme" of the play (118). Yet the music-hall, or more appropriately, the vaudeville and minstrel-show style in Sweeney Agonistes, which emerges from the use of ragtime music and jazz, adds dramatic value to the piece by increasing the 
tension with its jangling rhythms. An example of this is when Sweeney, in Crippen mode, talks about a man's 'need' to kill a girl:

SWEENEY: I knew a man once did a girl in.

Any man might do a girl in

Any man has to, needs to, wants to

Once in a lifetime, do a girl in [...] (Complete 124)

The implicit sexual nature and the threatening tone of these lines is highlighted by the use of jazz syncopations and the repeated use of the same words or phrases ("man", "do a girl in") or phrase patterns ("has to", "needs to", "wants to"). However, the fact that the line "Any man has to, needs to, wants to" is increasingly anti-climactic gives Sweeney less reasons for justifying the murder of a girl, and this actually makes his statement more disconcerting. Also, the use of the phrase "to do a girl in" is extremely colloquial and refers to the language of music-hall, a language that fits in more slickly with the songs and music present in the play.

The worth of Sweeney Agonistes cannot be measured by a conventional yardstick. Its relevance does not lie in its plot or a lack of it, but in its style, in its blending of the lyric and dramatic. Even its incomplete status does not matter in this regard. Ward seems to downplay the importance of its fragmentariness when he says:

[...] the fact remains that Sweeney Agonistes is a fragmentary experiment, and that the significance of the experiment lies more than anything else in the way it breaks away from the conventions of the contemporary stage. Conventional dramatic structures are abandoned. Even more strikingly, the conventional approach to dialogue is abandoned. Rhythmical patterning plays a far greater part in the structuring of dialogue than narrative convenience. (180)

Ward emphasizes the style of Sweeney Agonistes rather than its incomplete nature, focusing appropriately on the rhythmic and unconventional nature of the play. Howarth, too, ignores the fragmentariness of the text while assessing its significance: "A work does not have to be complete and rounded to be important. The fragmentary Sweeney Agonistes was and remains exhilarating, was invaluable to Eliot as an 
experiment in the application of his theories" (336). While Howarth claims that the text was invaluable to Eliot's experiments I believe it is the centrepiece of the lyricdramatic interaction in the writer's career. In many ways, Sweeney Agonistes is more successful than The Waste Land in highlighting the lyric-dramatic interface that Eliot sought in his work. However, its uniqueness, the difficulty encountered in pigeonholing it according to any neat categorisation and the playwright's attempts to downplay its importance post-1934 may be some of the reasons that it has been largely ignored or given short shrift by a significant body of critics.

Providing an ending for Sweeney Agonistes would prove to be an exercise in farcical writing for Eliot. The 'ending' which Eliot furnished to Flanagan in his letter discards the poetic style of the rest of the text completely, abandoning the striking jazz rhythms of parts one and two (Flanagan 83; see Chinitz, T.S. Eliot 126):

Enter an old gentleman. He is in full evening dress with a carnation, but otherwise resembles closely Father Christmas. In one hand he carries an empty champagne bottle, in the other an alarm clock.

THE OLD GENTLEMAN. Good evening. My name is Time. The time by the exchange clock is now nine-forty-five (or whatever it is). I come from the vacant lot in front of the Grand Union Depot, where there is the heroic equestrian stature of General Diego Cierra of Paraguay. Nobody knows why General Cierra is there. Nobody knows why I am there. Nobody knows anything. I wait for the lost trains that bring in the last souls after midnight. The time by the exchange clock is now 9:46.

SWEENEY. Have you nothing else to say?

OLD GENTLEMAN. Have you nothing to ask me?

SWEENEY. Yes.

OLD GENTLEMAN. Good. 
SWEENEY. When will the barnfowl fly before morning?

When will the owl be operated on for cataracts?

When will the eagle get out of his barrel-roll?

OLD GENTLEMAN. When the camel is too tired to walk farther Then shall the pigeon-pie blossom in the desert At the wedding-breakfast of life and death.

SWEENEY. Thank you.

OLD GENTLEMAN. Good night.

(As Old Gentleman leaves, the alarum clock in his hand goes off.)

(Flanagan 83-84)

Gone from the text are the vaudeville characters, with their amusing lyrics, and the brilliant interplay of language between speakers. In its place is the colourless and pompous preaching of the Old Gentleman, who symbolizes Father Time or Death, and the meaningless questions directed by Sweeney to him. Sweeney has lost his vaudeville air and jangling speaking rhythms, and he is subdued, almost resigned, in this passage. He is certainly not the Sweeney of the earlier fragments. As Galef points out, in this 'final scene', "the jazz rhythm is gone and the religious tenor is finally out in the open" as Eliot displays no interest at all in vaudeville or lyricism (Galef 505; see also Chinitz, T.S. Eliot 126). The melodramatic knocks at the end of the final chorus in part two are now transformed into "18 knocks" which sound "like the angelus", a Christian prayer, infusing the 'ending' with a strongly religious flavour (Flanagan 83).

With this 'ending' Eliot has also completely abandoned the plan for the melodrama featuring the murder and resurrection of Mrs. Porter. As Eliot's conversion to high Anglicanism took place in 1927 his introduction of the religious tenor in this 'ending' to Sweeney Agonistes becomes more understandable and, with the adoption of British citizenship by him in the same year, his abandoning of jazz rhythms and the vaudeville music of America is also logical (Gordon 223). In a way, this 'ending' is a precursor to some of the later drama that Eliot would write, 
especially The Confidential Clerk and The Elder Statesman where the poetry and lyricism seem to vanish altogether.

It seems that after Sweeney Agonistes Eliot was no longer interested in combining the lyric and dramatic in his work in the same manner as before. Although he had planned another play involving Sweeney to be titled The Superior Landlord this never materialised due to the arrival of Christian drama and The Rock in Eliot's life (Sidnell 263-265). ${ }^{12}$ As Chinitz says, "a new Sweeney play at this point would necessarily have resonated with Eliot's Christian sensibility" (T.S. Eliot 126). Eliot continued to blend the lyric and dramatic in his work for sometime after this, but the nature and intensity of this interaction would never be quite the same.

${ }^{12}$ Also see Sidnell 100-101 for the scenario of The Superior Landlord. 


\section{Chapter Five: The Lyric-Dramatic Dynamic after The Waste Land and Sweeney Agonistes}

\subsection{Introduction}

Eliot had planned to structure Sweeney Agonistes on the basis of Attic comedy, which was originally based on ritual. Like the structure of Attic comedy Sweeney Agonistes began with a 'Prologue' or exposition scene and moved into an 'Agon' supposed to depict a conflict. Eliot had asked Flanagan to read F. M. Cornford's book before the production at Vassar in order for her to understand the play which had an original plan based on Cornford's breakdown of the structure of Attic comedy and was linked to ritual elements (Flanagan 83 ). ${ }^{1}$ While attempting to blend primitivist themes and the structure of the Aristophanic melodrama with elements from jazz, an essentially modern music-style, Eliot had displayed an ambivalent stance towards the idea of the primitive in Sweeney Agonistes. The world that this ambivalence created in the play was too tenuous and terrifying to sustain itself for long.

Eliot attempted a conflation of the 'primitive' and the modern in The Waste Land with all its well-documented references to 'primitive' ritual and its use of jazz and vaudeville rhythms. For him the bringing together of the 'primitive' and the modern involved the convergence of the lyric and dramatic. In 1924 Eliot had asked whether it was "possible and justifiable for art [...] to persist indefinitely without its primitive purposes" ('Rev. of The Growth' 491). Earlier, in 1919, Eliot asserted that it was "certain that primitive art and poetry help our understanding of civilized art and poetry" and could be used to "revivify the contemporary activities" ('War-Paint' 1036). But he had always displayed an ambiguous attitude towards primitivism, stressing its importance at some times and attacking the sentimental nature of a return to it, at others.

An instance of this ambiguity is apparent in a paragraph from Eliot's 1919 essay 'War-Paint and Feathers', where he initially attacks the sentimentality of

\footnotetext{
${ }^{1}$ See also Cornford 2-3.
} 
Modernist primitivism before pointing out its significance in art: "The Red Man is here: what are we to do with him, except to feed him on maple sugar? And it is not only the Red Men, but the aborigines of every complexion and climate, who have arrived, each tribe pressing upon us its own claims to distinction in art and literature" (1036) Further instances of this ambivalence come to light when we examine Eliot's presentation of Sweeney, especially in his poetry, as a 'primitive' character that simultaneously delights and disgusts the reader.

This ambivalence began to be replaced by a sense of relative assuredness when Eliot assumed the Anglican faith in 1927, a year after the publication of 'Fragment of an Agon'. In the preface to his 1928 book For Lancelot Andrewes, titled for the famous Anglican preacher, Eliot declared that his "point of view" in religion may be described as "anglo-catholic", a branch of Anglicanism which tended more towards Catholicism than Protestantism (vii).

By now, Eliot had chosen to tread a via media, a middle path for his continued explorations into drama provided to him by the arrival of Anglicanism in his life. He viewed Anglicanism as a middle path in religion declaring that it was "the via media" was "the spirit of Anglicanism" (For Lancelot 4). This was because Anglicanism occupied a mid-point between Protestantism and Catholicism being neither too 'primitive' nor too 'modern'. It provided Eliot with an opportunity to blend the lyric and dramatic within a pre-ordained framework in The Rock (1934) and in Murder in the Cathedral (1935). The lyric-dramatic presentation within the religious structure was more stable and less experimental than the kind of interface between these elements in Eliot's pre-conversion works. By using the format of the medieval pageant in The Rock and of the Mass in Murder in the Cathedral Eliot no longer needed to turn to 'primitive' ritual per se or to the modern secular equivalents of ritual that he saw in the music-hall to bring together the lyric and dramatic. Consequently, we witness a reduction in the importance of jazz and music-hall elements in Eliot's drama after Sweeney Agonistes so that they almost completely vanish by the time we reach the domestic dramas with The Family Reunion. The playwright's movement away from the modern, secular settings of Sweeney Agonistes, with its suburban flat atmosphere, to the churches of the religious plays and drawing-rooms of English aristocrats in the later plays is symptomatic of this shift away from a pre-conversion world. No longer does Eliot seek to blend the 'primitive' and the modern in a popular setting. Subsequently these elements cease 
to co-exist in a similar manner in his work after The Waste Land and Sweeney Agonistes. As Chinitz puts it, "the avant-garde element of his earlier vision had by 1935 become secondary to his desire for a medium that could convey to a large public his own brand of Christian content" (T.S. Eliot 125). The pivotal moment in this changeover, according to Chinitz, was 1926, when Eliot started to receive religious instruction soon after the publication of the second Sweeney Agonistes fragment and just prior to his conversion (T.S. Eliot 126).

Eliot's conversion was an obvious starting-point for his entry into the sphere of religious verse drama. In this drama he initially sought to retain lyric elements by employing certain theatrical forms such as the medieval pageant in The Rock and, in Murder in the Cathedral, elements of both medieval Christian and ancient Greek drama. Even when he attempted to broaden his appeal by shifting out of the religious and medieval sphere to more modern settings and domestic drama with The Family Reunion, Eliot still employed ancient Greek elements. When this play failed on stage, Eliot no longer looked for an external dramatic style to apply to his plays in order to introduce the lyrical. Instead he decided not to use a Chorus or supernatural elements in his next play The Cocktail Party (1949). ${ }^{2}$ This play has neither the techniques of the ancient Greek drama nor the elements of Christian drama; consequently it has fewer lyrical moments than Eliot's previous plays. Following the critical and theatrical success of The Cocktail Party, Eliot preferred to stick to a modern domestic drama in The Confidential Clerk (1953) and The Elder Statesman (1958) with no real lyricism emerging from either of these plays.

In his poetry after The Waste Land, Eliot continued to display dramatic elements. There was a shift, however, from using the drama of the music-hall and of conversation between ordinary people in The Waste Land to using dramatic qualities of the Mass in parts of 'The Hollow Men' (1925) and in 'Ash-Wednesday' (1930). This shift is an obvious result of Eliot's Anglicanism. There was also a general reduction in the number of voices that occurred in these poems. Eliot continued to use some dramatic elements in the monologues 'A Song for Simeon' (1927) and 'Journey of the Magi' (1928) during this time. While Eliot displays quite a few dramatic qualities in the above poems and in Ol' Possum's Book of Practical Cats (1939), he does away with most of them by the time he gets to Four Quartets (1943).

2 “To begin with, no chorus, and no ghosts" (Eliot, On Poetry 85). 
This virtual disappearance of the dramatic from his poetry coincides with the decision to refrain from using too many lyric elements in his drama after The Family Reunion. It is difficult to miss a connection here. It is when Eliot makes a conscious decision to reduce the lyric in his drama that the dramatic elements completely vanish from his poems as well. This provides us a clue to the importance and trajectory of the lyric-dramatic interaction in his work as a whole.

In this chapter, I shall examine the presence of the lyric in Eliot's plays after Sweeney Agonistes before looking at dramatic elements in his poetry after The Waste Land. By doing so, I will trace the continuation of the lyric-dramatic interaction in Eliot's work and highlight its moment of disappearance. This disappearance is not a sudden occurrence but happens as a kind of gradual decline, especially through the drama, following the intense lyricism of Sweeney Agonistes.

\subsection{The Rock}

As pageant play

Because of its pageant form, The Rock has several highly lyrical moments, as highlighted by group and individual chanting and singing, as well as ballet. Being a Christian play, it also uses prayers, chants, hymns and processions that increase its lyrical nature. The presence of a Chorus, which chants its verses and carries with it the sense of the poetic drama of ancient Greece, adds to the lyrical quality of The Rock and reminds us of the choral moments in The Waste Land and Sweeney Agonistes. The elements of Christian medieval drama, ancient Greek drama, musichall and ballet combine to provide several moments of intense lyricism in the work.

The word 'pageant', used in association with The Rock, refers both to the medieval pageant and the early twentieth-century revival of this form in England. In order to appreciate the manner in which the modern pageant differs from the medieval one, we must examine what the medieval pageant was in the first place. Beginning around 1375, pageant plays, which involved performances of Biblical episodes, were presented by guild groups with the blessings of the church in England. Various play cycles, including the York, Chester and Wakefield cycles, 
arose in different parts of England with a varying number of episodes from the Bible around this time (Brockett 94). The plays "seldom observe a clear-cut, cause-toeffect relationship among incidents. They are episodic and there is little attempt to bridge the gaps between the short plays that make up long cycles” (Brockett 94).

While Eliot employed the episodic nature of the medieval pageant in The Rock, he also used the pageant's framework to present musical and dance elements, both of which played a prominent role in several medieval pageants (Brockett 105).

British dramatist Louis N. Parker, who was the moving force behind the revival of the pageant form in the twentieth century, modified the medieval pageant by crossing it with the Elizabethan chronicle or history play of the late sixteenth century. While the chronicle play often focused on the central figure of the king or hero, it could also focus on the history of a country such as England which was "dramatized and set on the stage" (Schelling 107). As in an Elizabethan chronicle play, the character of the Rock or St. Peter, even though he appears at only a few moments in Eliot's work, is the most important figure that binds the piece together. We also know that the work is set in London and deals with the history of the church in that city.

Parker retained the episodic nature of the chronicle and miracle plays while creating civic pageants for towns in England which portrayed the history of these places for large audiences (Richards 188). He defined the pageant form as

$[\ldots]$ the History of a Town from its remotest origins down to a date not too near the present; expressed in dramatic form; that is to say, in spoken dialogue; in action; in song and dance where dance and song are admissible... it is based on authentic history, but it welcomes folklore and picturesque traditions. It is divided into episodes corresponding with periods in the town's history. Each episode is complete in itself [...] (Parker 279)

Thus Parker shifted the pageant from a purely religious form to a secular genre used to present places in a historical manner. Eliot employs the religious elements of medieval pageant in The Rock while using a more modern style in the shape of secular songs from music-hall. The spoken dialogue, song and dance (the ballet of 
Dick Whittington and his cat) follows the episodic pattern of the pageant by having a bit of English church history presented, followed immediately and/or preceded by a choral performance or song. Eliot separated the episodes with passages of poetry performed largely by the Chorus. The episodes themselves are largely prose exchanges between the Cockney workers who are interrupted when figures from English church history make magical appearances in the middle of the episode. This episodic structure is also typical of ancient Greek drama where episodes between the characters were interspersed with Choral odes and dances.

\section{The Chorus, ritual and music}

The Chorus, which provides a lyrical base for the pageant as it moves from scene to scene, is an ever-present part of The Rock and has passages to recite after every episode. The opening chorus describes the changing, yet permanent patterns of nature:

The Eagle soars in the summit of Heaven

The Hunter with his dogs pursues his circuit.

O perpetual revolution of configured stars,

O perpetual recurrence of determined seasons,

O world of spring and autumn, birth and dying! (7)

The elevated language used here and the address to the world rather than to any actors or to the audience make us aware of the lyricism of this passage. The importance of the appearance of the Rock on stage is highlighted by singing and chanting by the Chorus, the group of Workmen and the Unemployed (8-10). At this moment, Eliot attempts to increase the lyricism of his work when he introduces an important character in the drama just as he would later do in The Family Reunion when Harry appears for the first time (Complete 291, 1.1). Thus we see that at a high point of the drama in Eliot's work we also have a great increase in the lyrical quality of the piece.

The closer Eliot comes to prayer and ritual in The Rock, the more lyrical he becomes. This is the case with the next chorus which occurs soon after the recitation 
of The Lord's Prayer and the performance of the Builder's Song at the end of Bishop Mellitus' sermon (The Rock 19). As King Sabert becomes more excited about the Christian faith following Melittus' sermon, Eliot introduces lyricism and ritual through the singing of the 'Our Father' before shifting into the Builder's Song. This, in turn, leads into the historical scene dissolving, the lights coming up and the chanting of the Chorus (18-19). Another example of increasing lyricism linked to ritual occurs when Rahere, a monk from the Middle Ages, blesses the modern-day workers who are building the church. At this stage, the pageant transitions into lyrical mode by having a semi-chorus of "Voices of Rahere's men", followed by the Builder's Song and the full Chorus (28-29). Thus, ritual and lyricism are not just techniques in the pageant but also provide an important connection between historical and contemporary times. They are a transitional link using the lyric to enable the drama to flow more easily. Although Eliot deals with Christianity here, I believe that his tendency to intensify the lyrical element whenever he comes closer to ritual has something to do with his early belief in a 'primitive' time where the lyric and dramatic were part of the same performance through ritual.

Following the dumb show of the Danish Invasion (41) we have the beginning of a very lyrical set of pages leading up to the end of part one (48). A chorus is followed by the entry of the Redshirts (Communists) and the Blackshirts (Fascists) who march about the stage and sing songs (42-44). The two groups are like separate semi-choruses that provide lyrical moments in the drama much like the main Chorus (43). Here, Eliot presents modern-day rituals linked to political belief systems, but these are portrayed in a negative light when compared to the older church rituals. Once again, the lyrical element increases with the presence of rituals.

When the Plutocrat enters and criticises the Church while presenting the Golden Calf, a symbol of capitalism as a pagan form of worship, the Chorus acts as defender of the faith, speaking up against him and against the Redshirts and Blackshirts (45-47). The language used at this time of conflict is very lyrical because the Chorus members speak or chant their words and also because they wish to make their case more emotionally powerful:

O world! forget your glories and your quarrels, Forget your groups and your misplaced ambitions, 
We speak to you as individual men;

As individuals alone with GOD. (46)

Shortly after these passages, the Rock suddenly appears and is seen "brooding on the pinnacle" (47). Although this moment seems quite flat since the Rock really does not do much, his very appearance and the centrality of the character to the main theme of the pageant points to why Eliot seems to get more lyrical almost every time before the Rock appears. This heightened lyricism is presumably meant to highlight the importance of the character of the Rock.

Similarly, in part two, the choral ode "How lovely are the tabernacles" leads to the Chorus Leaders speaking of the dedication of the Abbey Church of St. Peter and to a scene between St. Peter (the Rock) and a Fisherman on the Thames shore (78-79). Here the audience finally learns that the Rock is none other than St. Peter.

Like the end of part one, part two ends in high lyricism with a chorus (83-85) followed by a statement by St. Peter and a Benediction by the Bishop which includes the Builder's Song (86). This lyricism is linked to the performance of Christian ritual in the pageant and to the theme of church-building as represented by the ultimate builder of churches, St. Peter.

Music is one of the ways in which Christian ritual is presented in The Rock. This is similar to what happens in Murder in the Cathedral with the procession of priests, as we shall see (see 5.3, page 141 of this thesis, Complete 264, 2). During the production Eliot worked closely with Martin Shaw who composed the music for the pageant. E. Martin Browne, who directed The Rock and also devised its scenario, reveals that "the whole piece was conceived in terms of music as well as of words" (Making 12). In fact there was an orchestra of 40 players, the Lloyds Light Orchestra conducted by G. F. Brockless, and a small choir in the pit during performances (Martin Browne, Making 32). Martin Browne reveals that The Rock had a themesong as part of its plan, which was sung at various places in the play (Making 30). This is the Builders' Song, of which a stanza each appears in four different sections of the pageant. Each of the stanzas ends with the same line demonstrating a commonality of theme running through the play and linking it to ritual practice through the process of repetition: "A Church for us all and work for us all and God's / world for us all even unto this last" $(19,28,64,86)$. 
Except for the finale, this song seems to have been sung either from offstage or from the orchestral pit. Eliot repeats the first stanza at the end of The Rock. Here, the entire cast, Bishop and all, and even the audience stood and sang the song together:

\section{BENEDICTION}

ALL stand for this, and then sing together.

Ill done and undone,

London so fair

We will build London

Bright in dark air,

With new bricks and mortar

Beside the Thames bord

Queen of Island and Water,

A House of Our Lord.

A Church for us all and work for us all and God's world for us all even unto this last. (86)

At song's end, also play's end, an actual bishop dressed in complete Christian regalia stepped forward and blessed the audience and cast as in the ending of a Mass or Service. Besides this, the stage directions indicate that everybody is supposed to stand as if they are at the end of a Mass and the performance of the song together is another indication of this conclusion. Thus, the performance was intricately linked to Christian ritual. The Bishop also acts as a Christian version of a shaman or medicine man of 'primitive' ritual who 'heals' the audience as it were with his magical powers as seen in the benediction he provides. This scene is similar to and yet different from the pageantry of the funeral of Beckett at the end of Murder in the Cathedral (see 5.3, page 144 of this thesis, Complete 281-282). The Rock involves greater direct audience involvement as compared to the later play since the audience actually have to stand and sing in The Rock rather than just watch a procession in Murder in the Cathedral. 
Much of the music and chanting throughout The Rock is ultimately linked to the ritualistic ending of the pageant. The opening sequence includes the alternate chanting of the Workmen and of the Unemployed. In fact, the final lines from the Chant of Workmen parallel the lines of the Builders' Song: "A Church for all / And a job for each / Each man to his work" (11).

Also present is the element of group interaction which is an important part of the ritual theory of drama that Eliot subscribed to, as seen in chapter one, and which is reflected in the congregation-like singing of the audience. We have already seen how audience interaction was important to The Waste Land in the Sosostris scene and is an important part of even earlier Eliot poems such as 'Suite Clownesque'. The audience in The Rock was given a song-sheet to join in during certain songs. This is a clear indication of the producers' needs to ritualise the pageant. Martin Browne tells us that when the last stanza of the Builder's Song was sung at the close of the play "quite a good proportion of the audience picked up his [Martin Shaw's] tune [the Builders' Song] well enough to join the cast and singers" (Making 31). This was perhaps because the words were provided to the predominantly Christian audience/congregation who may have felt obliged to join in thanks to their faith and the context of the performance. This kind of communal singing has echoes of the bythen bygone era of the music-hall in England and it is no surprise therefore that The Rock contains one music-hall song which I will deal with soon. It is also reminiscent of the audience participating as a kind of congregation during the Mass, joining in with the recessional hymn at the end of the service, which is appropriate to the style and theme of the pageant and suited the purposes of the producers, the Church.

Apart from the already mentioned rendition of the 'Lord's Prayer' and Eliot's own Christian-themed song, the 'Builder's Song', there are even more specifically Christian rituals performed in The Rock which provide more lyrical moments in the text. The episode of the blessings of the candidates for the Crusades (61-64) is taken directly from Christian liturgy, specifically from the old Latin mass. The exchanges are in Latin and would be sung or chanted by the actors playing the Bishop (in this case a real Bishop was probably used for the role) and the respondents. Also, the Pater Noster (or The Lord's Prayer) would be chanted or sung in this section as it used to be in the old Latin mass. Before the Pater Noster we are presented with a version of the sixth century Latin hymn Vexilla Regis Prodeunt by the choir accompanied by strings (61). This hymn was written by the Christian poet Venantius 
Fortunatus and was first performed in 569AD as part of a religious procession carrying the relics of the true cross in France. The hymn used to be a part of the Holy Week liturgies until 1955 (New Catholic 14: 467-468).

There is also secular music used in The Rock, which fits in with Eliot's overall plan to come up with a new verse drama that blends Christian ritual with the lyrics of Elizabethan verse drama and music-hall. The first prose section in the pageant is prefaced by the gravedigger's song from Hamlet (5.1.89-92). The song acts as an interlude between the lyrical opening of the play and the exchanges between the Cockney workers. ${ }^{3}$ By borrowing a Shakespearean song here Eliot demonstrates a parallel between his own endeavour to bring the lyric into the drama and Shakespeare's incorporation of the Elizabethan love lyric into Hamlet.

In addition to the use of lyrics from Elizabethan drama, Eliot employs the music-hall tradition when the workman Ethelbert and his wife break into song. He rewrote Fred Gilbert's music-hall song 'In Trinity Church I Met My Doom' (1894) for this section. In Eliot's version of the song, Mrs. Ethelbert pretends that a huge group of people are eagerly waiting to hear her husband sing, while Mr. Ethelbert seeks permission from an imaginary audience (actually the audience for The Rock) to sing. Mrs. Ethelbert behaves in the fashion of the Master of Ceremonies of musichall who introduces the act to the audience, a bit like Sosostris being introduced by her assistant in our workshop production or the comedian in 'Suite Clownesque' introducing the performers, and ensures the right kind of environment for the song to be successful:

\section{MRS. ETHELBERT.}

....'Ere's 'undreds and 'undreds of people all waitin' to 'ear you sing that song what was wrote for you special.

ETHELBERT [with a start]. Oh, askin' your pardon all. 'Ere goes.

\footnotetext{
${ }^{3}$ Shakespeare's song is a variant of a popular Elizabethan song by Thomas Lord Vaux 'The Aged Lover Renounceth Love' which appeared in Tottel's Miscellany (1557).
} 
SONG

\section{ETHELBERT.}

When I was a lad what 'ad almost no sense

Then a gentle flirtation was all my delight [...]

The song becomes a duet shared between husband and wife with words rewritten from the original lyrics to fit the action of building the church in The Rock. The original music-hall song presented a man who regrets marrying the wrong girl because she had lied about her age and financial status:

She told me her age was five-and-twenty,

Cash in the bank of course she'd plenty;

I, like a lamb, believed it all -

I was an M U G.

At Trinity Church I met my doom,

Now we live in a top-back room,

Up to my eyes in debt for "renty,"

That's what she's done for me! (Bauerle 8)

As compared to this comic ditty, Eliot's song is optimistic about the Ethelbert's marriage, given they are still happy together and that Mrs. Ethelbert considers her husband as having a reputation "no one can smirch", perhaps partly because he's a foreman "what's buildin' this church" (68). Eliot re-contextualises the song and changes its words to suit his purposes in The Rock - to present a married couple who are living the good Christian life. The song retains its music-hall element in terms of performance but also takes on Christian elements through its new words.

Thus, we have seen that the lyrical exists at several important moments of the drama in The Rock enhancing and enriching its performance. This is something that we have already observed with The Waste Land performance (see conclusion of chapter 3). The presence of the lyric in the work is made possible because of the pageant form but it is also the result of Eliot's use of ritual, elements of the Mass, ancient Greek drama, Elizabethan lyric drama, the music-hall and contemporary 
verse drama. The pageant style of The Rock and the fact that Eliot had to employ a huge cast of 300 , mostly amateur, actors to accommodate the church's needs in this collaborative effort ensured that there would be plenty of musical and Choral performances in the pageant as everyone had to be involved in some way or the other. This need for collaboration and inclusion meant that Eliot had to work with an orchestra and music composer as well, besides following a scenario prepared by someone else (Martin Browne). Additionally, Eliot's love for the music-hall had not quite disappeared and while the Cockney of his workers in The Rock does not quite match up to the Cockney of the women in the pub in part two of The Waste Land, it occasionally retains some of the quality of a performance from the halls, especially in the scene with the Ethelberts (The Rock 67). The reduction in the importance of the music-hall element to Eliot's work is, however, evident in The Rock as the Christian elements of the pageant take over. In the pageant we can see a bit of the merging of the old style of Sweeney Agonistes with more of a new style that anticipates Murder in the Cathedral in terms of its use of hymns and Christian themes and rituals. The Rock retains enough of the lyric to ensure that it is not often seen as drama at all. In any case, it is a pageant, a form which exists on the border between the dramatic and lyric. The Rock's collaborative nature, Christian overtones, outdated and nebulous form, and restrictive audience appeal have, however, ensured that it has been almost completely ignored within the Eliot literary and dramatic canon.

\subsection{Murder in the Cathedral: Christian ritual and Greek Choral traditions}

Eliot's decision to deal with the murder of the Archbishop of Canterbury St. Thomas Becket in 1170 for his next play was appropriate given that it allowed him to employ verse more easily and to use elements of medieval drama such as the four tempters borrowed from the morality play. ${ }^{4}$ It is not surprising that Eliot used this form of verse drama in Murder in the Cathedral given that morality plays were accorded something of a revival at earlier Canterbury Festival productions, especially in the 1929 performance of Everyman (Potter 237-38), and given the playwright's fairly

\footnotetext{
${ }^{4}$ Morality plays used Vice as a stock character. Pickering observes that "like the medieval morality play [...] Murder is first a drama of temptation and a conquering of temptation" (201).
} 
recent conversion. The religious nature of the plot and the form of the Mass provided Eliot with a ready-made structure within which he could present the lyrical in the drama.

In America, Maxwell Anderson had already set an example of how historical stories could be used to write verse drama with his plays Elizabeth the Queen and Mary of Scotland, both staged in 1933 (Brockett 495). The religious nature of Murder in the Cathedral meant Eliot could use several elements from Christian liturgy to enhance the play's lyricism. He also employed a tradition from ancient Greek drama in the form of the Chorus which used music, chanting and dance-like movements as part of performance. ${ }^{5}$ This restoration of the Greek Chorus is modernised by its application to Christian ritual in Murder in the Cathedral (see Jones 58).

The lyric is originally presented at the start of the play through the opening chorus of Canterbury women. Eliot made use of the conventions of ancient Greek tragedy here as revealed to us by Peter: "Like a Greek tragedy [...] Murder in the Cathedral opens with a Chorus, that of the Women of Canterbury, and like its Attic counterpart this Chorus gives us a good deal of information (often simply atmospheric) about the time, place and potentiality of the scene" (366).

In a similar manner to ancient Greek tragedy the Chorus is used to introduce us to the main character, to make us familiar with the setting and to create tension. Even before Becket steps onto the stage for the first time we already experience the Chorus' sense of fear:

\section{CHORUS.}

O Thomas, Archbishop, leave us, leave us, leave sullen Dover, and set sail for France. Thomas our Archbishop still our Archbishop even in France. Thomas Archbishop, set the white sail between the grey sky and the bitter sea, leave us, leave us for France. (Complete 244-245, 1)

Just as the entrance of the Rock in The Rock is preceded by a Choral Ode or Parados, so too, the Chorus in Murder in the Cathedral expresses fears about

\footnotetext{
${ }^{5}$ For more on the forms that Eliot used in Murder in the Cathedral see Pickering 200.
} 
Becket's return shortly before the Archbishop's arrival on the scene. The drama gains in intensity through the juxtaposition of the Chorus' lyrical outbursts against Becket's calmness which is expressed in his opening line, "Peace. And let them be, in their exaltation" (Complete 245, 1).

Soon after the Fourth Tempter finishes his interaction with Becket we have extremely lyrical exchanges which involve, at first, the Chorus, then, the Four Tempters, followed by the Three Priests. The three separate groups next come together for an amazing interchange which helps to portray the conflict within Becket's soul:

\section{CHORUS, PRIESTS and TEMPTERS alternately.}

C. Is it the owl that calls, or a signal between the trees?

P. Is the window-bar made fast, is the door under lock and bolt?

T. Is it rain that taps at the window, is it wind that pokes at the door?

(Complete 256, 1)

At this moment, Eliot not only employs the musical element of the Chorus but also includes two semi-Choruses comprising the priests and tempters to create a more complete lyrical effect. The contrast between the different voices as chanted or sung by the Chorus or each semi-Chorus increases the overall lyrical nature of the piece and creates a combined sense of doom, making it seem as if all of England is worried for Becket on his return. Here, the three forms that Eliot has used to present the lyric all combine at a high point of the drama. He employs the Chorus of ancient Greek drama, the priests as representative of Christian ritual and the tempters as elements of the morality play to create this highly lyrical moment which ultimately leads to Becket being able to free himself from all doubts (see Potter 239):

THOMAS. Now is my way clear, now is the meaning plain: Temptation shall not come in this kind again.

(Complete 258, 1)

\footnotetext{
${ }^{6}$ Something similar is attempted by Eliot in The Family Reunion with the presentation of the Chorus in Act One of that play (see page 145 of this thesis).
} 
From this moment on, Becket, having passed the tempters' tests, is resolute in his desire to die for his belief and for no other reason. It is as if the lyrical moment has acted as part of a purification ritual that paves the way for his sacrifice, a kind of paralleling of the killing of the Divine King described in Frazer's The Golden Bough (350). Thus by infusing his drama with lyrical elements Eliot returns it to a ritualistic state.

Much of the drama of the play emerges through the use of Christian ritual and lyrics. For instance, at the start of part two, the dramatic emerges through the priest's procession (especially the use of banners) and through the music. It is similar to the kind of church drama produced in Medieval England with the priests becoming actors: ${ }^{7}$

[THE PRIESTS stand together with the banners behind them]

FIRST PRIEST. Since the Holy innocents a day: the fourth day from Christmas.

THE THREE PRIESTS. Rejoice we all, keeping holy day.

FIRST PRIEST. As for the people, so also for himself, he offereth for sins.

He lays down his life for the sheep.

THE THREE PRIESTS. Rejoice we all, keeping holy day.

(Complete 264, 2)

Here, the First Priest assumes the role of the celebrant while the response is provided through the repeated line "Rejoice we all, keeping holy day." This line, taken from Psalms 42.4, becomes a kind of refrain sung by the chorus of priests. There are several similar lines taken from or referring to the Book of Psalms which are sung in this scene. These include: "Princes moreover did sit" (Psalms 119.23), "In the midst of the congregation he opened his mouth" (Psalms 22.22) and "Out of the mouth of

\footnotetext{
${ }^{7}$ This is similar to what Eliot presents in The Rock as we have seen.
} 
very babes" (Psalms 8.2). The use of so many lines from the Book of Psalms adds to the sense that we are watching a Christian drama or a drama about a Christian saint performed in a church. The stage directions reveal that at certain points in this scene the Introits of St. Stephen and St. John should be heard. This is another way in which Christian ritual and lyrics are used in the play. Coghill describes an Introit as: "a variable part of the Mass, composed of a versicle or sentence with phrases taken from the psalms, or elsewhere in the Bible, said or sung, as the priest approaches the altar to celebrate the Eucharist" (123). The Introits in the play would be sung by a choir as the actors playing the priest moved in procession. Thus, the lyrical rhythms of the Introits would most likely be used to pace the movements of the priests in this scene.

The play's first director Martin Browne tells us that the music was sung by “the warden and students of St. Augustine's College, in a small gallery rigged above the entrance door" of the chapter house at Canterbury Cathedral where the first performance of the play was given on 15 June, 1935 as part of the Canterbury Festival (Making 63). This would provide the sense to the audience of a kind of surround sound with the music coming from behind them and making them feel part of the congregation or like participants in this Christian ceremony in the play. While the opening of the play is set in a Greek tradition, Eliot begins to mix this with the presence of Christian ritual as the work progresses.

Eliot uses the chorus starting "I have smelt them, the death bringers" as an interlude between scenes as Becket waits for the knights to return to murder him (Complete 269, 2). At this point, the Chorus serves to create a sense of approaching doom. The rhythm of the Chorus' lines becomes faster as we approach the murder reflecting the growing anxiety and sense of helplessness of the Chorus members who can only watch in agony while the archbishop is about to be murdered. Like a Greek Chorus, the Chorus of Murder in the Cathedral is unable to make a difference to the action of the play as Becket moves towards his inevitable doom. The Chorus is aware of this when it says: "I have smelt them, the death-bringers; now is too late / For action, too soon for contrition" (Complete 270, 2).

The Chorus has accepted the inevitable even before seeing it being played out. The Chorus members know they are fixed in position by nature of their being poor women, who cannot intercede in high matters of religion and state in the society of their time, and cannot act to prevent the murder to come. The lyrical outburst 
regarding a lack of action is also linked to the dramatic reality of the Chorus not being part of a dramatic convention that allows members to interfere in the preordained scheme of things (see Martin Browne, 'From The Rock'59). The Chorus uses the language of Christian ritual to seek Becket's forgiveness, thus converting the archbishop into a kind of dying god: "O Lord Archbishop, O Thomas Archbishop, forgive us, forgive us, / pray for us that we may pray for you, out of our shame" (Complete 271, 2).

More combinations of Christian ritual with a Greek-like Chorus follow. While the priests attempt to transport Becket to safety, a choir sings the Christian hymn Dies Irae or 'The Day of Wrath' even as the Chorus bursts into an expression of lament for Becket's impending sacrifice (Complete 272, 2). Thus while Eliot moves the scene along, he also provides lyrical performances by the Chorus and a choir that add to the tension and atmosphere of foreboding. Coghill informs us that in the Chorus' lament, at this moment, Eliot imitates the rhythmic form and even the content of the Dies Irae in the first three and last two verses ${ }^{8}$. Eliot uses the rhythm of the Chorus' lines juxtaposed against that of the Dies Irae, one of "the great masterpieces of mediaeval lyric poetry" (Coghill 130):

\section{CHORUS.}

Dust I am, to dust am bending,

From the final doom impending

Help me, Lord, for death is near. (Complete 273, 2)

Through its interpretation of the Dies Irae the Chorus portrays Becket's inner fears even while expressing its own anxieties in what is, clearly, an instance of the simultaneous mixing of the traditions of ancient Greek drama and Christianity. Here, the choir that sings the Dies Irae represent the lyric element, while the Chorus that performs for the audience clearly stand for the dramatic. A comparable moment in The Waste Land occurs when we have the lines sung from Wagner's Tristan und Isolde representing the purely lyrical (since it is removed from the context of the opera) and the appearance of the hyacinth girl and her lover on the scene as dramatic (Complete 61-62, 1. 31 onward).

\footnotetext{
${ }^{8}$ See Coghill 130, n. 31 for original verses from the Dies Irae.
} 
From this highly lyrical moment we move into the climax of the play where Becket confronts his murderers. As the knights fall upon Becket, the Chorus breaks into a powerful lamentation about the loss of innocence. At the highest point of the tragedy it is only through the lyrical that expression can be provided:

CHORUS. Clear the air! clean the sky! wash the wind! take stone from stone and wash them.

The land is foul, the water is foul, our beasts and ourselves defiled with blood. (Complete 275, 2)

This is similar to what happens, with lesser intensity and success, in The Family Reunion when the Chorus breaks into a lament on the death of the dowager Amy (see 5.4, page 148 of this thesis, Complete 349, 2.3).

Murder in the Cathedral ends with a choral ode performed while the choir sings a Te Deum, an early Christian hymn of praise (New Catholic 13: 771). The final words of the play are largely taken from the Kyrie Eleison or 'Lord Have Mercy' of the Mass which is normally sung or chanted:

Lord, have mercy upon us.

Christ, have mercy upon us.

Lord, have mercy upon us.

Blessed Thomas, pray for us. (Complete 282, 2)

While there is only one line at the end of the printed version of the play which shows that Becket's name has been added to the litany of saints, Martin Browne reveals that, in its first performance, the "Priests and Chorus carried candles, and sang the litany which calls the roll of the saints to which Thomas's name has just been added" while they carried Becket's body down the "central aisle of the chapter house and out into the cloister" (Making 70). Thus the première of the play finished with a lyrical performance of Christian ritual the recitation of which would almost certainly have been used to time the movement of the procession as it exited

Murder in the Cathedral employs several intermingled dramatic traditions to ensure that the lyric has a strong presence in the drama. At the height of the drama 
these forms, especially the Greek Chorus and Christian ritual, intermingle successfully to highlight the importance of the lyric.

\subsection{A return to secular drama: The Family Reunion}

\section{The shift from religious drama}

Eliot used the framework of Christian practices, stories, and beliefs for The Rock and Murder in the Cathedral as these were both works specially commissioned by the Church. ${ }^{9}$ Naturally, when he moved away from plays produced by the Church, he reduced the use of Christian rituals in his drama. Eliot was aware that Murder in the Cathedral, a religious drama in which audiences expected to "put up with poetry", was "a dead end" in his aim towards providing a poetic drama for the modern stage since he could not apply it to more modern and secular forms (On Poetry 79). He now believed that poetic drama had to enter into "the world in which the audience lives", a realm obviously different from that of Becket and the medieval Church, if it was to "enter into overt competition with prose drama" (On Poetry 81-82). Subsequently, he wrote his first play for the professional theatre, The Family Reunion.

This play is set in an aristocratic country-house in contemporary England and deals with the sense of guilt felt by Lord Harry Monchensey, who is uncertain whether he has murdered his wife on their voyage home. Harry is haunted by the Eumenides, avenging spirits of ancient Greek myth, literature and drama who are also known as the Erinyes or the Furies. They are "primeval beings born of the blood of the mutilated Uranus, avengers of crime, especially crime against the ties of kinship" (Harvey 181). The Eumenides feature in Choephoroe or the Libationbearers and Eumenides, the second and third plays of Aeschylus' Oresteian trilogy. In the latter play they constitute an avenging Chorus which, unsuccessfully, demands retribution for Orestes' slaying of his mother Clytemnestra and her paramour Aegisthus (Harvey 297-298). Aeschylus furnishes us with a description of the

\footnotetext{
${ }^{9}$ The Rock was staged in order to raise money for the Forty-Five Churches Fund of the Diocese of London which was meant to provide for the construction of new buildings for parishes, while Murder in the Cathedral was first produced as part of the church-sponsored Canterbury Festival in 1935.
} 
Eumenides as seen through the eyes of Orestes in Choephoroe: "Like Gorgons, with grey cloak, / And snakes coiled swarming round their bodies!" (142).

In The Family Reunion, Eliot created his own ritual-like moments to heighten its lyricism such as at the end of the play when Agatha and Mary perform a ritualistic duet (Complete 349-350, 2.3). He also continued to use a Chorus, albeit in a different manner from the Choruses of The Rock and Murder in the Cathedral. The presence of the Chorus and the Eumenides in The Family Reunion shows that Eliot still employed elements from ancient Greek drama just as he had in his religious plays.

There is a lyrical element in every scene of The Family Reunion. Thus part one, contains Agatha's lyric (Complete 290) followed by a chorus ("Why do we feel embarrassed") in scene one (290-291), scene two features a spoken duet between Mary and Harry (310), while scene three has a chorus ("I am afraid of all that has happened) (315-316) followed by Agatha's lyric at the end (316). Similarly in part two, scene one ends with a chorus ("In an old house there is always listening") (328329), scene two contains Harry and Agatha's lyrical duet and Agatha's lyric (Complete 335-337) and scene three has a chorus ("We do not like to look out of the same window") (348-349) followed by the closing duet between Agatha and Mary (349-350). The lyrical elements often exist at the ends of scenes or when Eliot seeks to heighten the importance of the 'action' in the play by using the Chorus to comment on it. But the lyric is also presented when characters enter a kind of dream world at important points in the drama.

"Why do we feel embarrassed?" The Chorus in The Family Reunion

Of primary interest in The Family Reunion is the Chorus which, unlike that in The Rock and Murder in the Cathedral, does not exist as a separate entity throughout the play. Instead the Chorus in The Family Reunion has to constitute itself each time on the spur of the moment from individual characters within the family. Thus four characters who were previously exchanging dialogue as individuals, in part one, scene one, later form a Chorus which sometimes speaks together and at other times speaks individually. These include Ivy, Violet, Gerald and Charles, all relatives of the dowager Amy: 
CHORUS (IVY, VIOLET, GERALD and CHARLES): Why do we feel embarrassed, impatient, fretful, ill at ease,

Assembled like amateur actors who have not been assigned their parts?

Like amateur actors in a dream when the curtain rises, to find themselves dressed for a different play, or having rehearsed the wrong parts,

Waiting for the rustling in the stalls, the titter in the dress circle, the laughter and catcalls in the gallery?

CHARLES. I might have been in St. James's Street, in a comfortable Chair nearer the fire.

IVY. I might have been visiting Cousin Lily at Sidmouth, if I had not had to come to this party.

GERALD. I might have been staying with Compton-Smith, down at his place in Dorset.

VIOLET. I should have been helping Lady Bumpus, at the Vicar's American Tea.

CHORUS. Yet we are here at Amy's command, to play an unread part in some monstrous farce, ridiculous in some nightmare pantomime. (Complete 290-291, 1.1)

Here, Eliot blends two different styles of Chorus, first presenting it as a group, and then as individual voices within the group, before bringing it back together as a group again. The presentation of individual voices as a kind of medley finishing with a joint Chorus is not too dissimilar from the mode of choral presentation in musichall. By referring to the atmosphere among the audience in a theatre or music-hall ("the rustling in the stalls, the titter in the dress circle") the Chorus creates a sense that its words are part of a wider performance occurring within a theatrical space that is not dissimilar to the music-hall - a bit like Mrs. Ethelbert creating the atmosphere for her husband's music-hall performance in The Rock.

At other moments in the play the Chorus' statements reflect the ills befalling the family in an attempt to create an overall sense of doom akin to what an ancient Greek Chorus would strive for in tragedy (Complete 315; Avery 12). For example, the Chorus of part one, scene three tells of its fear of oncoming tragedy: 
CHORUS. I am afraid of all that has happened, and of all that is to come;

Of the things to come that sit at the door, as if they had been there always.

(Complete 315, 1.3)

While the trepidation expressed by the Chorus in The Family Reunion may seem exaggerated, given the aristocratic English domestic setting and the lack of action in the play, the above words are an echo of a similar motif used by Aeschylus in his tragedy Agamemnon, the first in the Oresteian trilogy, where the Chorus members are equally unable to express what makes them afraid:

CHORUS. What is this persistent dread

Haunting, hovering to show

Signs to my foreboding soul [...] (Aeschylus 76)

The words of Aeschylus' Chorus create the mood for the impending death of the returning conqueror-king Agamemnon who is murdered by Clytemnestra, his unfaithful wife. As compared to the Greek Chorus, the words of Eliot's Chorus are supposed to evoke a sense of gloom linked to Harry's guilt-ridden conscience and to Amy's death later in the play. The inability of the Chorus members to express their true fears in both plays is linked to their inability to do anything to assuage these fears.

The final chorus towards the end of the play follows Amy's death offstage. There is an outpouring of grief by the Chorus which helps to create a mood of mourning for the audience who have not seen Amy die:

CHORUS. We have suffered far more than a personal loss -

We have lost our way in the dark. (Complete 349, 2.3)

Here, the Chorus performs one of the tasks of a traditional Greek Chorus by creating an atmosphere of despair following the death of one of the important characters. While the intensity of the Chorus at this moment is a far cry from that of the Chorus of Canterbury women mourning over Becket's death in Murder in the Cathedral, it is interesting that Eliot employs the lyrical at the climax of the drama in The Family Reunion. However, the Chorus of The Family Reunion is at a distinct disadvantage as 
compared to that of the Canterbury drama since it does not mourn the tragic death of any significant historical or religious figure and its lyrical outpourings sound incongruous to the intensity of whatever little action does occur in the secular play.

\section{Lyrical duets}

Eliot uses lyrical duets, sections where two individual characters, who may or may not be in the midst of a normal dialogue, break out into alternate lyric passages which share a common theme or are part of a ritual. Consider the lyric duet between Harry and his cousin Mary:

HARRY. Spring is an issue of blood

A season of sacrifice

And the wail of the new tide

Returning the ghosts of the dead

Those whom the winter drowned

Return to the land in the spring?

Do the dead want to return?

MARY. Pain is the opposite of joy

But joy is a kind of pain

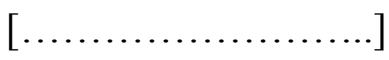

Harefoot over the moon?

HARRY. What have we been saying? [...] (Complete 310, 1.2)

Here, the characters enter into a reverie where they reveal their innermost thoughts to the audience. As Avery observes, the characters shift "from specific conversation into a kind of song [...] which rises in emotional crescendo until it breaks into a near love scene" (15). They snap out of this "song", returning to the present when Harry asks "What have we been saying?" It is as if both characters are unaware of what has happened in the preceding lyrical duet between them. 
This is one of the emotional high points of the drama, the moment where we are about to learn about the possibility of a future relationship between Harry and Mary which might redeem him. The duet also occurs just before the first appearance of the Eumenides and Harry's reactions to their physical presence on stage when he nearly breaks down in front of Mary:

HARRY. O Mary!

Don't look at me like that! Stop! Try to stop it!

I am going. Oh why, now? Come out!

Come out! Where are you? Let me see you,

Since I know you are there, I know you are spying on me.

(Complete 311, 1.2)

Similar to the Rock's appearance in Eliot's pageant play, lyricism is used before the appearance of the Eumenides. Since the Eumenides are originally taken from ancient Greek verse drama it is significant that Eliot turns towards the lyric close to the time of their appearance in his play. The arrival of the Eumenides on stage is attached to a stage device, that is, the parting of the curtains to reveal the spirits in the window embrasure (Complete 311, 1.2).

Something similar happens in part two, scene two where a major section of intense lyricism begins with a duet between Harry and Agatha. The duet shifts in the middle of a passage by Harry which the Eumenides interrupt by their appearance, turning it, instead, into a soliloquy addressed to the spirits:

AGATHA. You have a long journey.

HARRY. Not yet! not yet! this is the first time I have been free From the ring of ghosts with joined hands, from the pursuers, And come into a quiet place.

Why is it so quiet?

Do you feel a kind of stirring underneath the air?

Do you? don't you? a communication, a scent

Direct to the brain ... but not just as before,

Not quite like, not the same ....

[The EUMENIDES appear] 
and this time

You cannot think that I am surprised to see you.

(Complete 336, 2.2)

Here, too, the appearance of the Eumenides is linked to Harry's lyrical outburst and is dependent on the opening of the curtain. The moment Harry has made up his mind to follow the Eumenides the curtains close. Agatha now begins a highly lyrical soliloquy soon after she opens the curtains and steps in "somnambular fashion" into the "place which the EUMENIDES had occupied":

AGATHA. A curse comes to being

As a child is formed

In both, the incredible

Becomes the actual

Without our intention

Knowing what is intended. (Complete 336, 2.2)

The lyrical tends to be more clearly expressed when the characters enter a kind of trance, what Eliot dubbed a "poetic fantasia" (On Poetry 83). Evidently, Agatha is in this kind of trance in this scene. The moment she returns to the room Agatha returns to her normal self as expressed through her language, questioning what she was saying before this as if she did not know what she had just said:

What have I been saying? I think I was saying

That you have a long journey. You have nothing to stay for.

(Complete 337, 2.2)

The lyrical here is tied to a space linked to the Eumenides, a space whose existence is determined by the opening and closing of the curtain. With the disappearance of the Eumenides and with Agatha's removal from the space associated with these spirits the lyricism of the scene reduces. This scene goes against the realistic setting and the stereotypes of drawing-room drama as it presents the lyric and supernatural elements in the play. Rather than "not being related to the action" the lyrical passage here is at the core of the presentation of the conflict in Harry's mind (Jones 121). 
The two characters with whom Harry shares lyrical duets and who seem to understand him best, Mary and Agatha, also share the last moments of the play in a ritualistic duet. The movement by Agatha and Mary, who walk slowly in a ritualised manner around what is supposed to be Amy's birthday cake lit with candles, should go in time with the lyrics provided (Martin Browne, Making 101). The words spoken by the pair refer to their movement around the table as when Agatha says "follow follow" we see Mary following her round the table (Complete 349, 2.3). Similarly, when Mary says "follow follow" it seems that Agatha is following Mary as they go clockwise around the table $(350,2.3)$. Agatha refers to the circle that they make in the process in her part of this lyric duet between the aunt and niece:

AGATHA. This way the pilgrimage

Of expiation

Round and round the circle

Completing the charm [...] (Complete 350, 2.3)

While lyricism is not always visible in The Family Reunion it becomes crucial at pivotal moments in the work. By reducing the overall lyricism of the play Eliot has not reduced the importance of the lyrical in The Family Reunion since he turns to it at the most important parts of the drama. The play's failure at the box-office has less to do with the mere presence of the lyrical element and more to do with a commercial audience that found it difficult to fathom its lyricism. It has also to do with Eliot's failure to link this lyricism more intricately to the overall plot. The Family Reunion suffers from a thinness of plot and a sense of obscurity linked to the attempted use of lyric elements from ancient Greek tragedy in the realistic setting of English domestic drama. Eliot's turn back to ancient Greek drama and ritual seems hollow thanks to his use of modern-day characters in an aristocratic English family home. The Eumenides also appear out of place in the play, having nothing to say, and their appearance on stage did not work at all. Eliot's attempts to introduce some elements from 'primitive' performance here failed to work altogether and led to his future abandonment of any form that would assist the introduction of the lyrical in drama. As Eliot himself said "the deepest flaw of all" in The Family Reunion lay in "a failure of adjustment between the Greek story and the modern situation", in a "failure to adjust the ancient with the modern" (On Poetry 84). Little wonder then 
that Eliot later insisted the Eumenides should be "omitted from the cast, and be understood to be visible only to certain of my characters, and not to the audience" (On Poetry 84). All this meant that Eliot was to reduce the lyrical elements in his later plays.

\subsection{The Cocktail Party and after}

By 1944, Eliot had altered his critical position on the nature of verse drama. While earlier he had attacked realism and naturalism, he now used the idea of a verse drama to speak of going beyond naturalism:

A verse play is not a play done into verse, but a different kind of play: in a way more realistic than 'naturalistic drama', because, instead of clothing nature in poetry, it should remove the surface of things, expose the underneath, or the inside, of the natural surface appearance. ('Introduction', Shakespeare 9)

This observation is a change from Eliot's earlier stated dislike of realism in the theatre when he had claimed that realism did not "satisfy the craving for ritual" in drama ('Dramatis' 305-306). If Eliot had earlier sought a return to ritual for drama, his linking of verse drama to realism and naturalism had a lot to do with his abandoning of primitivism and his entrance into the world of commercial theatre. $\mathrm{He}$ sought to be successful in mainstream theatre $-\mathrm{a}$ theatre that did not care about experiments with dramatic form. Such a change in his dramatic theory impacted the way in which he viewed his poetic drama at the time. His reduction of the lyric style used in his earlier plays may have had something to do with this shift in perception. By now Eliot had stopped commenting on the need to return drama to ritual. By removing the need for 'primitive' ritual in his drama Eliot moved towards a more realistic drama which would subsequently have less of the lyrical in it.

Eliot's belief that he should not clothe "nature in poetry" perhaps led him to drop the use of the Chorus and the Eumenides of Greek drama from his next play (On Poetry 85). He revealed his disappointment with the failure of the Eumenides and the Chorus in The Family Reunion which led him to lay down for himself, in The 
Cocktail Party, "the ascetic rule to avoid poetry which could not stand the test of strict dramatic utility" (On Poetry 85). Subsequently the lyrical content in The Cocktail Party is significantly reduced as compared to The Family Reunion. Eliot uses lyricism in the later play only at one or two moments when the drama reaches a particularly high point at which the lyrical becomes unavoidable. The fact that The Cocktail Party is based on Euripides' verse tragi-comedy, Alcestis, does not really intensify its lyricism either.

Around this time, Eliot argued that it was not essential to have poetry all the time in drama. Eliot's entry into the world of commercial drama meant the need to reduce his lyricism. This meant an increasing conventionalism and a movement towards realism which was likely linked to the commercial/artistic failure of The Family Reunion. However, he maintained that there were certain moments of drama that might need more poetry than others:

If our verse is to have so wide a range that it can say anything that has to be said, it follows that it will not be 'poetry' all the time. It will only be 'poetry' when the dramatic situation has reached such a point of intensity that poetry becomes the natural utterance, because then it is the only language in which the emotions can be expressed at all. (On Poetry 78)

Thus Eliot believed that when drama was most dramatic, it was also most lyrical. This is, in a way, a mirror image of what we discovered through The Waste Land production where we realised that at its most lyrical, the poem was most dramatic (see conclusion to chapter three). His reduction of the lyrical in the drama after 1939 was based on his reduction of the overall intensity of action in his plays. There is no Chorus and no lyrical soliloquies, duets or runes in The Cocktail Party. However, there are occasional moments of lyricism which remind us of the mixing of the lyric in the drama that Eliot used so often in Sweeney Agonistes and in his plays of the 1930s. It is interesting that such moments arise when the characters enter into ritualistic mode, although the ritualism involved is pseudo-Christian rather than 'primitive'.

One such moment is the libation performed for Celia by Reilly, Alex and Julia, at the end of Act Two. The psychologist Harcourt Reilly acts as a kind of priest 
and modern-day Heracles who opens up the pathway to salvation for ordinary mortals such as Edward, Lavinia and Celia. Alex and Julia act as mysterious guardians to the trio.

By the end of Act Two, Reilly has convinced Celia to enter the sanatorium and is aware of its link to her future martyrdom as a Christian nurse. Hence, the lyrical libation that follows has links to Christian ritual. The reciting of the libation is also attached to the drinking, a ritualistic act which is symbolic of the title and of most of the play:

REILLY: Protector of travellers

Bless the road.

ALEX: Watch over her in the desert.

Watch over her in the mountain.

Watch over her in the labyrinth.

Watch over her by quicksand.

JULIA: Protect her from the voices

Protect her from the visions

Protect her in the tumult

Protect her in the silence.

[They drink] (Complete 422, 2)

The reduced lyric element in The Cocktail Party was the result of a conscious effort for change on Eliot's part. However, this did not prevent Eliot from including a song in the music-hall style into the play. 'One-eyed Riley', sung by the Unidentified Guest (later revealed as Reilly), reflects Eliot's continued love for music-hall and has a score set down by Eliot's friend Mary Trevelyan as prepared "from the author's [Eliot's] dictation" (Complete 441):

\section{UNIDENTIFIED GUEST:}

As I was drinkin' gin and water, And me bein' the One Eyed Riley, Who came in but the landlord's daughter And she took my heart entirely (Complete 365) 
Both 'One-eyed Riley' and the songs in Sweeney Agonistes are music-hall in style.

But 'One-eyed Riley' sounds out of place at an upper-middle class party as compared to a scene from Sweeney Agonistes. In fact, Cray tells us that the song was originally a bawdy number from Britain dating at least from the end of the nineteenth century, and later became a popular tune with New Zealand and Canadian troops during World War II $(101,103)$. He provides us with this version which might have been the original model for Eliot's rewrite:

As I was sitting in O'Reilly's bar

Lis'ning to tales of blood and slaughter,

Suddenly a thought came to my mind,

Thought I'd shag O'Reilly's daughter. (Cray 102)

Eliot provides a more refined version of the song in The Cocktail Party but it still seems to be out of place in the upper-class drawing-room comedy scenario that the play presents.

There are other elements in The Cocktail Party which remind one of the lyricism of Sweeney Agonistes, especially in the party scenes of Acts One and Three, with their many instances of backchat and inflections (Donoghue 115). However, these rhythms in The Cocktail Party seem more affected and stilted than in Sweeney Agonistes and the half-rhymes do not flow as smoothly as the earlier play:

JULIA: who is he?

EDWARD: I don't know

JULIA: $\quad$ You don't know

EDWARD: I never saw him before in my life

JULIA: But how did he come here?

EDWARD: $\quad I$ don't know.

JULIA: $\quad Y o u$ don't know! And what's his name?

Did I hear him say his name was Riley?

EDWARD: I don't know his name.

JULIA: You don't know his name?

(Complete 365) 
The improvisations here are not half as interesting as those in the opening exchange between Doris and Dusty in Sweeney Agonistes (Complete 115) ensuring that the incessant repetition of phrases by Edward and Julia hardly serves to provide an exciting rhythm to the overall lines.

Reilly also quotes from Shelley's verse play Prometheus Unbound (1820) in Act Three when the characters learn of Celia's death in Kinkanja (Shelley 238-239, 1.1). Shelley's play was a closet verse drama never meant for performance. By quoting from it Eliot tries to introduce a lyrical moment at an important point in his own drama, the announcement of Celia's martyrdom:

\section{REILLY. $\quad$ Ere Babylon was dust}

The magus Zoroaster, my dead child, Met his own image walking in the garden. (Complete 437)

It seems that Reilly can best respond to news of Celia's death in a lyrical fashion. This is similar to the reaction of the Chorus to Becket's assassination in Murder in the Cathedral. However, this moment of lyricism in The Cocktail Party sounds hollow in the light of the overall tone of the work. It seems more like a flash of intellectual affectation by Reilly, since he can only quote from another work, rather than present a sense of true lyricism arising out of the situation itself. It also seems that by using lines from Shelley's closet verse play Eliot is acquiescing to the idea that verse is fine for 'read' drama (closet drama), but does not actually work on an actual stage.

While containing the last remnants of the lyric in Eliot's drama, The Cocktail Party also sowed the seeds for the kind of drawing-room and domestic comedy he would rely on for his last two plays and which would ultimately lead to the demise of the lyric element in Eliot's plays. The Cocktail Party still possesses the occasional music-hall tune and sections of jazz-inflected dialogue, but, for all practical purposes, it marks the demise of the lyric-dramatic interaction in Eliot's work.

Eliot's last two plays The Confidential Clerk and The Elder Statesman contain no trace of the lyric even though they are written in verse. There is no Chorus in the Greek style and no use of Christian or medieval drama in these plays. In them Eliot provides a modern-day family drama with no music-hall or vaudeville songs either. These plays are no doubt written in verse, but it is verse that contains very 
little, if any, lyrical quality. For example, Act Three of The Confidential Clerk begins with this exchange between Lady Elizabeth and Sir Claude Mulhammer which is as far from being lyrical as possible, perhaps, partly the result of setting the scene in the Business Room of Sir Claude's London house:

LADY ELIZABETH. Claude, what are you doing?

SIR CLAUDE. Settling the places.

It's important, when you have a difficult meeting,

To decide on the seating arrangements beforehand.

I don't think you and I should be near together.

Will you sit there, beside the desk? (Complete 493, 3)

This is a far cry from the jazz rhythms and music-hall atmosphere of Sweeney Agonistes or even the lyrical duets of The Family Reunion. Clearly the lyric element in Eliot's drama had completely vanished by the 1950s, bringing to an end the long and sustained experimentation on the nature of the lyric-dramatic interface in his career.

\subsection{The dramatic in the poems after The Waste Land}

The nature of the dramatic in Eliot's poetry shifted after The Waste Land thanks to his conversion to Anglicanism and his entrance into the realm of drama. In his poetry from now on Eliot no longer used the dramatic characters that he employed in the Sweeney poems and in The Waste Land. While 'The Hollow Men' (1925) still contains dramatic voices in addition to a central lyric voice, the dramatic in this poem is less obvious than in The Waste Land. The dialogues of The Waste Land almost completely disappear in the later poems. 'Journey of the Magi' (1927) and 'A Song for Simeon' (1928) continue Eliot's experiments in the dramatic monologue form but do not provide us with as strong a sense of the audience as The Waste Land does. What have also disappeared from Eliot's poetry by this time are the theatrical elements from music-hall or vaudeville that featured in early poems like 'Suite Clownesque' as in The Waste Land. 
However, Eliot's poetry still contained the occasional voice, the sporadic sense of an audience and of movement linked with Christian themes, ritual and prayer. With the introduction of prayer, though, he moved towards using a more solitary, introspective speaker who speaks to God ('A Song for Simeon’) or contemplates his sinfulness ('Ash Wednesday', 1930). While the shift towards Christian ritual would be mirrored by the nature of his drama and while it still allowed for dramatic moments in his poetry, it would ultimately turn him inwards, causing him to move away from the outer world of Sweeney and his earlier poems, and finally moving him towards the pure lyricism of Four Quartets.

It is important to recall at this stage the dramatic elements that we discussed in the earlier chapters because I will refer to some of them while I examine the presence of the dramatic in the poems after 1922. These elements included movement, the use of voice or voices, time, rhythm, tension or conflict, choral elements, music, and dialogue. Some of these elements are occasionally present in the poems that were written after The Waste Land.

\subsection{Voices in 'The Hollow Men' (1925)}

Eliot wrote 'The Hollow Men' between the publication of The Waste Land and Sweeney Agonistes. Although it was written and published before his conversion, we can observe some elements of Christian ritual in 'The Hollow Men' along with pagan ritual, both of which combine to infuse it with a dramatic quality. 'The Hollow Men' incorporated three different poems that were put together in 1925, including the lyrics 'Doris' Dream Songs' and 'We are the hollow men' with which the work begins.

While Brady argues that the final published version of the poem is completely lyrical (43), Bush believes that its first part involves a "group of speakers" which voices a "single emotional mood, as a Greek chorus might give vent to the prevailing mood at the end of a tragedy". Bush also points to the fact that "the members of Eliot's new Chorus were not anonymous" (95). They are the conspirators of the failed Gunpowder Plot of 1605 in London who speak as one voice describing their detention in the poem's opening lines: 
Our dried voices, when

We whisper together

Are quiet and meaningless

As wind in dry grass

Or rats' feet over broken glass

In our dry cellar. (Complete 83, 1, 11. 5-10)

Eliot thus continues to use the sense of a Chorus that he employed in The Waste Land earlier and that he presents in a more overt manner in his plays: The Rock, Murder in the Cathedral and The Family Reunion.

As compared to 'Doris' Dream Songs', which essentially make up parts two, three and four of 'The Hollow Men', part one is "less rarefied", "more 'objective, more like the dramatic monologue of a historical figure" (Bush 96). In other words, we might imagine the conspirators, who exist between life and death after the discovery of the plot, sharing their sense of woe.

In part five of the poem, Eliot parodies a popular children's nursery rhyme and links it both to the ritual of Guy Fawkes' Day in England meant to celebrate the failed Gunpowder Plot and to Christian ritual which, with this poem, becomes an increasingly important part of both his poetry and religious drama. There is also a connection to one of the epigraphs of the poem, the cry of the children for money on Guy Fawkes' Day, “A penny for the Old Guy” (Complete 83).

The use of this voice is linked to the ritual of the children's nursery rhyme that appears in part five. Its dramatic quality is pointed out by its italicization which ties it to the children's nursery rhyme in part five which is also italicized. A sense of the dramatic is also present in the first and last stanzas of the fifth section of the poem which are modified versions of the nineteenth-century English nursery rhyme "Here we go round the Mulberry bush" (Southam 160):

Here we go round the prickly pear

Prickly pear prickly pear

Here we go round the prickly pear

At five o'clock in the morning. (Complete 85, 5, 11. 1-4) 
This is the way the world ends

This is the way the world ends

This is the way the world ends

Not with a bang but a whimper. (Complete 86, 5, 11. 26-30)

Traditionally, children sing this nursery rhyme while holding hands and moving round in a circle. Eliot's use of italics reminds us of the need for the lines to be sung and his employment of the rhyme, which most of us would have used at some point in our childhood, evokes memories of how it goes along with movement or action, an important element of drama.

There is a possibility of a dramatic voice emerging also in the lines from the Lord's Prayer ('Our Father'), part of the Mass. ${ }^{10}$ Such usage foreshadowed the use of similar language in The Rock and Murder in the Cathedral. However, Eliot shifts the meaning of the Lord's Prayer by breaking up the lines and displaying the doubt in the speaker's mind by not completing the line from The Lord's Prayer:

For Thine is

\section{Life is}

For Thine is the (Complete 86, 5, 11. 89-91)

By cutting short the line and by removing the prayer from the context of its recitation, Eliot reduces its dramatic aspect. He does not put these words in italics as he does with the nursery rhyme, suggesting they may not be spoken aloud. Instead the words from The Lord's Prayer used in snatches before this and counter-pointed between stanzas are italicized and could be spoken out loud:

Between the idea

And the reality

\footnotetext{
${ }^{10}$ The prayer was taught by Jesus to his disciples (Matthew 6.9-13).
} 
Between the motion

And the act

Falls the Shadow

For Thine is the Kingdom

(Complete 85, 5, 11. 77-81)

There is an obvious link between the children's nursery rhyme, the child's cry in the epigraph and The Lord's Prayer here in that they are all italicized, suggesting that these lines are spoken out loud. In this instance the dramatic voice that utters the prayer and the children's voices are juxtaposed against that of the lyric speaker meditating on reality and illusion. Eliot highlights the tension between the children's voices, The Lord's Prayer being spoken by an outer, dramatic voice on the one hand, and the inner reflections of the 'hollow man' (who appears to be a penitent or a new believer struggling to turn towards God) on the other. ${ }^{11}$ It is when the speaker is most distraught about his faith that the poem becomes most dramatic with the introduction of the distorted nursery rhyme and the prayer from the Mass. Thus, at its most intense the poem is also most dramatic.

\subsection{The Ariel poems: 'Journey of the Magi' and 'A Song for Simeon'}

Since Eliot's Ariel poems were specifically produced for Christmas greetings they allowed him more opportunities to use Christian ritual and liturgy. The first Ariel poem, 'Journey of the Magi' (1927), was published around the time of his conversion. While beginning to demonstrate more signs of his religious identity the poem contains dramatic elements through the use of dramatic monologue and the quotation from a sermon of Lancelot Andrewes used at the start. The poem begins with a line from Andrewes' original sermon delivered on Christmas Day, 1622 (Southam 180):

\footnotetext{
${ }^{11}$ The children celebrate Guy Fawkes' Day and are, thus, antagonistic to the 'hollow men', the plotters who are now reduced to the straw men that children love to see burned.
} 
'A cold coming we had of it,

Just the worst time of the year

For a journey, and such a long journey:

The ways deep and the weather sharp,

The very dead of winter.' (Complete 103, 11. 1-5)

Eliot had quoted the original lines from Andrewes' sermon in his essay on the preacher in For Lancelot Andrewes: "It was no summer progress. A cold coming they had of it at this time of the year [...]" (19) In the poem, Eliot changes the word "they", used by Andrewes in his sermon to refer to the Magi, the Three Wise Men who travelled from the East to pay homage to the Christ child, to the more personal "we". This makes it seem as if the opening lines of his poem are spoken by one of the Magi. However, the use of inverted commas only for the opening five lines allows us to hear this voice as possibly being different from the Magus who later provides the dramatic monologue in the poem.

As we have seen already, with our study of the voices in The Waste Land in chapter three, this is not the first time that Eliot uses inverted commas to bring out the presence of another voice in his poetry. We are also aware that the second voice belongs to another one of the Magi. Since the journey of the Magi is celebrated on the sixth of January every year as the Feast of the Epiphany we can see that Eliot uses Christian ritual and myth to present a story which would go well with the Christmas greeting his poem was part of. Interestingly, one of the early dramatic productions of liturgical drama in Europe involved the performance of the Epiphany play, and one of the first connections we make on hearing of the Magi is their appearance as part of the extended Nativity play performed every Christmas (see Hartnoll 495-496).

We assume that the second speaker is a Magus because he refers to his arduous journey on camelback. Also, we can guess that he is a foreigner because the cities are "hostile" and towns "unfriendly" to him as he passes by (Complete 103, 1. 14). His reference to a birth and his return, along with his friends, to their "Kingdoms" after the journey reveals his status to us (Complete 104, 1. 39). Thus Eliot presents the character of the Magus through his description of the journey and what he saw and felt on the way all presented within the context of a dramatic monologue. 
The Magus' monologue ensures that the story of Christ's birth is represented from the point of view of the speaker who is narrating the tale to an auditor who writes it down (Southam 182). We know this when the Magus says:

All this was a long time ago, I remember,

And I would do it again, but set down

This set down

This [...] (Complete 104, 11. 31-34)

Through this metafictional moment Eliot makes us aware that his character is addressing an audience and that there is something dramatic happening within the poem which involves the Magus speaking to his audience. The dramatic action taking place is also that of the actual writing.

The second Ariel poem, 'A Song for Simeon' (1928), is also a dramatic monologue spoken by another Biblical figure, Simeon, and based on the Biblical presentation of the Christ child to Simeon in a temple. Simeon was a holy man of Jerusalem who, according to scripture, met Mary, Joseph and Jesus as they entered the temple when Jesus was 40 days old (Luke 2.25-35). On taking Jesus into his arms Simeon uttered the prayer Nunc Dimittis which is still used in many churches, and pronounced a prophecy alluding to the crucifixion (Luke 2.29-32). Part of the poem's dramatic power emerges from its status as the monologue of a character in a situation: that is Simeon receiving the Christ child. What we do not see in the poem is the act of Simeon holding the infant Jesus in his arms during the prayer. Although Eliot does not provide us the picture of Simeon and the Holy Family together, we can begin to imagine it in our minds when we read the poem given the poem's context.

The poem is a dramatic monologue in that it seems to be spoken aloud. However, since Simeon's audience is God the work appears more lyrical than dramatic. It is either spoken or sung outwardly as a prayer by Simeon to God or is a mix of Simeon's outward prayers to the Lord and internal meditations on life, death and spirituality. The presence of the refrain "Grant us thy peace" (Complete 105, 1. 8) points to the possibility of the words being spoken outwardly since this line is taken from the Mass itself and is normally recited out loud or sung as part of the Agnus Dei or 'Lamb of God' just before the Communion or the receiving of God. It goes well with Simeon's reception of his Lord and subsequent death. He seeks God's peace 
before he can attain ultimate consummation of his relationship with the divine through the final communion of death.

Eliot uses parenthesis to highlight where Simeon speaks to Mary to offer her a prophetic warning regarding her son's death. Interestingly, the direct address to the human character is in parenthesis, in a kind of aside, while the monologue to God is outside of it: "(And a sword shall pierce thy heart, / Thine also)" (Complete 106, 11. 32-33). These lines are taken almost verbatim from the Bible but they are the only ones in the poem which are addressed directly to a human audience. ${ }^{12}$ In this sense, they are the ones in which Simeon's voice comes closest to sounding dramatic. Thus, once again, though the use of punctuation, parenthesis in this case, Eliot presents to us a dramatic voice.

Eliot's Anglicanism slowly but surely ensures the replacement of a human and possibly dramatic audience of speakers and listeners in his poetry with a spiritual and divine being as an unfathomable audience. He replaces ritualistic and theatrical elements and dialogue seen in his earlier poetry with largely internalized prayer-like poems. This leads to a reduction of some of the dramatic features in his poetry. However, we can still observe that there is the occasional dramatic voice and even dramatic action in these poems.

\subsection{Christian ritual, hymns and the Mass in Ash-Wednesday}

After these two dramatic monologues Eliot turned to writing a more lyrical piece, Ash Wednesday, to express his feelings regarding his conversion. The title of the poem is taken from a Christian ritual on the first day of Lent where the penitent's forehead is smeared with ash by the priest during Mass as a reminder of human mortality and sinfulness. Most of the poem's dramatic features are brought to the fore by the structure of the Mass on which it is based. There is a sense that the penitent-speaker of the poem may be inside a church participating in an AshWednesday service. Even though the physical act of ash being smeared on the penitent's forehead by a priest is not represented, it is hinted at through the title and

\footnotetext{
${ }^{12}$ Simeon tells Mary: 'Behold, this child is set for the fall and rising again of many in Israel: and for a sign which shall be spoken against (yea, a sword shall pierce through thy own soul also), that the thoughts of many hearts may be revealed' (Luke 2.34-35)
} 
the words of the speaker at the start of the poem and implied later through the presence of several prayers used during a Mass.

In the poem the penitent moves as in a Mass from a Biblical reading to a prayer to a hymn. Part two is similar to a reading during the Mass as it deals with "the vision of [the prophet] Ezekiel, in which God predicts the spiritual regeneration of his people" through the coming to life of the bones which represent the Israelites in captivity in Babylon in the sixth century BC (Southam 170-71). There seems to be a single voice reading out this passage or partly chanting it:

And God said

Shall these bones live? Shall these

Bones live? (Complete 91, 2, 11. 45-47)

This line is directly taken from Ezekiel 37: 1-4 and is part of Ezekiel's vision. The reader then continues with words taken partly from Ezekiel 37: 8-10 which may seem to be part of the same reading:

\section{And God said}

Prophesy to the wind, to the wind only for only

The wind will listen. And the bones sang chirping

With the burden of the grasshopper, saying [...]

(Complete 91, 2, 11. 62-65)

Part two comes to a close with lines borrowed almost directly from Ezekiel 48:29 which are spoken by God again and which seem to be part of another reading during the Mass:

This is the land which ye

Shall divide by lot. And neither division nor unity

Matters. This is the land. We have our inheritance.

(Complete 92, 2, 11. 93-95)

A voice is heard in part five as a kind of refrain coming in between the stanzas containing the speaker's lamentation for the possibility of God's Word being lost. This is the voice of God (as it appears in Micah 6.3) which repeats the line, "O my 
people, what have I done unto thee" (Complete 96, 5, 1. 176). These words have been included in the Mass on Good Friday, which commemorates Christ's death and is also the day for which Ash Wednesday prepares the penitent. Here they are part of the Reproaches where Christ who is dying on the cross asks his people what he has done in order to deserve his death: "O my people, what have I done unto thee? Or in what have I grieved thee? Because I brought thee out of the land of Egypt, thou hast prepared a cross for thy Saviour.” (Southam 176)

Eliot fuses the Ash Wednesday service with that of Good Friday in a kind of collation of Masses to present a more complete view of the rites surrounding Easter. The Reproaches are traditionally chanted by the priest while the congregation is venerating the cross. The cry of Christ is a call for action in the poem, a cry to the sinner to return to the fold. Similarly, in part three, the speaker prays:

Lord, I am not worthy

Lord, I am not worthy

But speak the word only

(Complete 93, 3, 11. 117-119)

These lines are taken directly from the text of the Mass. But they are also linked to the Biblical story of the Roman centurion at Capernaum who recites this prayer when he asks Christ to cure his sick servant: "Lord, I am not worthy that thou shouldst come under my roof, but speak the word only, and my servant shall be healed" (Matthew 8:8).

We could read the line in Eliot as being spoken by the Centurion though we do not have the exact context for it. Eliot has not marked the line as different by using italics as he did in 'The Hollow Men' or quotation marks as at the start of 'The Journey of the Magi'. He may have differentiated it though by setting it aside in a separate stanza. Equally, however, we could see the line as being a prayer that has become part of the Mass and is spoken by the congregation when the Celebrant presents them with the Host just before Communion in this fashion: "Lord I am not worthy to receive you but only say the word and I shall be healed." The Church has replaced the words "my servant" in the Centurion's sentence to "I" thus removing the context of the Centurion's story and providing a new context for it within the Mass. Eliot, in turn, omits the entire latter section of the prayer thus leaving the words 
hanging or incomplete. This isolates them to some extent from both the context of the Centurion's prayer as well as that of the Mass. However, we could imagine that the speaker is saying the words while he is at a Mass that is not described. This could provide a dramatic context for the words, but that context has not been elaborated upon and involves more than a slight leap of faith. As the prayer is presented out of the context of the Mass its dramatic value is reduced. Another reason for its loss of dramatic power is the fact that Eliot cuts short the prayer leaving out its most important part, its performative aspect, where the centurion says that the speaking of Christ's word will heal his servant (Brady 51).

In part six, the penitent speaker recites the opening words of the Confessional rite, which are normally spoken to a priest: "(Bless me father) though I do not wish to wish these things" (Complete 98, 6, 1. 191). The line spoken to the priest is in parenthesis while what seem to be the inner thoughts of the penitent are outside. By re-enacting the Confessional rite Eliot is dramatizing this part of the poem since many Christians attend confession during Lent. However, he does not complete the first line of the words spoken to the priest: "Bless me father for I have sinned". This shows that the lines are mostly the inner meditations (lyrical) of the speaker who is lost in his thoughts, rather than the outward (dramatic) interactions with the priest. Confession, while not being part of the Mass itself, is, nevertheless, an important part of Christian ritual around Lent and is normally conducted before the Ash Wednesday service.

The hymns used in the poem could be seen as structurally part of the poem's Mass-like pattern. The opening hymn could well be the Ave Maria or 'Hail Mary' which appears at the end of part one as one of the speaker's prayers for contrition or mercy from God: "Pray for us sinners now and at the hour of our death" (Complete 90, 1, 1. 40). The dramatic in this line may exist in its being sung or spoken by the speaker or a congregation and choir. The Ave Maria is one of the most beautiful lyrics of the Christian faith. A hymn to Mary, it is often sung, the most popular melodies being those composed by Franz Schubert and the Bach-Gounod Ave Maria. However, it can also be extremely dramatic, if one sees and hears a performance within a church, especially during a Mass.

At the end of part four Eliot uses a line from the Salve Regina or 'Hail, Holy Queen', a hymn sung to Mary just before Advent (“And after this our exile" (Complete 95, 4, 1. 148). The prayer is an appeal to Mary to save the human race 
which has been lost in exile, thus continuing with the theme of the exile of the Israelites established in earlier parts of the poem. Eliot uses one of the lines from the prayer to end part four. He reduces the dramatic element in this hymn, as in others, by not presenting it in its entirety.

The order of the Mass is not followed in Ash Wednesday but this does not mean that its drama has not been used to further the Christian themes of the poem. After examining the text I came up with a pattern of the Mass in the poem. I have put the page numbers and line numbers of the parts of the Mass in parenthesis so that one can get an idea of how these parts do not appear in the same order as they do in the Mass. I have also conjectured about the order of hymns and psalms:

Opening hymn: Ave Maria (Complete 90, 1, 11. 40-41)

Kyrie eleison: Lord have mercy (Complete 89, 1, 1. 26)

Reading: From the Book of Ezekiel regarding the Song of the Bones

$$
\text { Ezekiel 37, 1-4 (Complete 91-92, 2, 11. 43-88) }
$$

Psalm: Teach us to care (Complete 90, 1, 1l. 138-139)

Gospel and Sermon: "If the lost word is lost" (starting Complete 96, 5, 1. 49)

Prayer before Communion: "Lord, I am not worthy" (Complete 93, 3, 11. 117-19)

Communion hymn: Anima Christi (Soul of Christ) (Complete 99, 6, 1. 218)

Recessional: Salve Regina (Complete 95, 4, 1. 148)

This demonstrates the incredible borrowing from the Mass in the poem, a borrowing which includes the complete structure of the rite. It brings with it the realization that both the lyric and dramatic elements of the Mass have an effect on the poem. The fact remains that since Eliot does not overtly present the poem at the level of the Mass, the dramatic elements are, more often than not, submerged beneath the lyric voice.

\subsection{Old Possum's Book of Practical Cats}

Andrew Lloyd Webber has revealed that he used Eliot's Old Possum's Book of Practical Cats (1939) for his musical Cats as the verses were "extraordinarily musical" (online). The musical quality of Eliot's poems points to their lyricism but 
the verses also have several dramatic qualities. The first important dramatic element is the presence of characters in the form of the cats. They are well portrayed, often through their actions, and we get a picture of them in our mind's eye strolling down a street or burgling a house. This depiction of the cats through action brings them closer to being dramatic.

We also hear several voices in the poems which tend to sound dramatic when they are involved in an exchange with another voice or voices. For example in 'Munjojerrie and Rumpelteazer' the cook grumbles about the stealing of the joint and the family responds to his complaint:

And the cook would appear from behind the scenes

And say in a voice that was broken with sorrow:

'I'm afraid you must wait and have dinner tomorrow!

For the joint has gone from the oven - like that!'

Then the family would say: 'It's that horrible cat!

(Complete 219, 11. 24-28)

This provides the possibility of a dialogue-like exchange with the cook in despair over the loss of the meal and the family upset over going hungry. All these voices tend to create a dramatic environment in which the cats perform or go about doing what cats do best.

There is also a sense that the speaker who describes the cats is talking to an audience throughout the book (except for 'Cat Morgan Introduces Himself' which is a monologue by Cat Morgan, and 'Song of the Jellicles'). This is made clear through the use of parenthesis for certain lines of the speaker. For example in ' $\mathrm{Mr}$ Mistoffelees' the speaker provides an aside which sounds like it is meant to be spoken: "(At least we all heard that somebody purred)" (Complete 225, 1. 48).

Many of the poems seem like music-hall songs: none more so than Cat Morgan's monologue which is directly addressed by the cat to his audience. The music-hall quality of this performance adds to the dramatic value of the poem as we imagine the cat performing the lines in the context of the theatre: 
I once was a Pirate what sailed the 'igh seas -

But now I've retired as a com-mission-aire:

And that's how you find me a-takin' my ease

And keepin' the door in a Bloomsbury Square. [sic]

(Complete 236, 11. 1-4)

Thus Old Possum's Book of Practical Cats possesses several dramatic qualities some of which were used to transform it into one of the most successful musicals ever. I will not dwell much on this book as its dramatic qualities are quite evident. Also, I believe that Webber's Cats succeeds not due to Eliot's lines alone, but also, in no small measure, due to the music, dance, costumes and the spectacle that is the musical. These elements have little to do with Eliot and are the result of the efforts of Webber and his production team. Hence, I will refrain from commenting further on the musical.

\subsection{Four Quartets}

In Four Quartets Eliot largely turned away from the dramatic and moved closer to the pure Romantic lyric. This is especially observed in the fact that he uses a solitary speaker who is a thinly veiled version of the poet himself through the work. In addition to his meditations this lyric speaker often uses very personal references to his life. The repetition of certain lines or phrases at different places in the quartets provides the poems with musical themes, which boosts the argument that each poem within the work is seen as "a poetic equivalent of the classical symphony, or quartet, or sonata [...]" (Gardner, Art 36-7)

Four Quartets are clearly a return to the Romantic-style lyric, a form with which Eliot experimented in a very basic way at the start of his poetic career before he encountered Laforgue. Abrams describes the style of the greater Romantic lyric:

They present a determinate speaker in a particularized, and usually a localized, outdoor setting, whom we overhear as he carries on, in a fluent vernacular which rises easily to a more formal speech, a 
sustained colloquy, sometimes with himself or with the outer scene, but more frequently with a silent human auditor, present or absent [...] Often the poem rounds upon itself to end where it began [...]

(Abrams, Correspondent 76-77)

Such a description is very close to the nature of the speaker in the Four Quartets and as is quite well known the speaker returns to the beginning at the end of the poems. For this very reason, there is less of the dramatic in Eliot's poem. There are obviously no possibilities for music-hall or vaudeville performances in this work. Nor does Eliot employ the dramatic structure of the Mass in Four Quartets. As Matthiessen puts it, "the greatest change from his earlier poems is that his intentions now [in Four Quartets] are only intermittently dramatic" (193).

However there are other ways in which some dramatic elements, though few, seem to emerge in the quartets. The opening lines of 'Burnt Norton' were "originally written as a comment by the Second Priest after the exit of the Second Tempter" in Murder in the Cathedral (Gardner, Composition 39). Eliot took the lines out of context and altered them for the purposes of his poem, shifting the words from the dramatic character in the play to the lyric speaker in the poem. Thus we see that the link between the lyric and dramatic in Eliot's work was so strong that he was not averse to reusing matter from his lyric plays in his later poetry.

Dramatic spaces or places where people or characters seem to interact exist at some places in the poems. One of these is in 'Little Gidding' II where Eliot presents the scene the morning after a German bombing raid of London during World War II:

In the uncertain hour before the morning

Near the ending of interminable night

At the recurrent end of the unending

After the dark dove with the flickering tongue

Had passed below the horizon of his homing

While the dead leaves still rattled on like tin

Over the asphalt where no other sound was

Between three districts whence the smoke arose

I met one walking, loitering and hurried 
As if blown towards me like the metal leaves

Before the urban dawn wind unresisting.

(Complete 193, 2, 11. 25-35)

Here Eliot provides what is close to a dramatic meeting which takes place in a dramatic space. The words conjure up the space that was London during the war and provides us with a dramatic context for the meeting between the speaker and the "familiar compound ghost" (Complete 193, 2, 1. 42). There is a dialogue-like exchange between the ghost and the speaker which makes the passage appear more dramatic:

I said: 'The wonder that I feel is easy,

Yet ease is cause of wonder. Therefore speak:

I may not comprehend, may not remember."

And he: 'I am not eager to rehearse

My thoughts and theory which you have forgotten.

(Complete 194, 2, 11. 55-59)

However, the lack of characterisation of the speakers takes away from the dramatic elements of this passage and leaves it more lyrical than dramatic. The two speakers sound like each other; they do not have a separate dramatic life. Additionally, the passage is reported as having happened in the past, thus missing the dramatic immediacy of passages in The Waste Land. In The Waste Land even after Tiresias or the speaker reports having seen something he returns to speaking in the present tense:

I Tiresias, old man with wrinkled dugs

Perceived the scene, and foretold the rest -

I too awaited the expected guest.

He the young man carbuncular arrives [...]

(Complete 68, 11. 228-31)

This return to the present allows The Waste Land to retain its dramatic immediacy more easily as compared to Four Quartets, where the moment always seems to be in the past. 
By its very nature Four Quartets is more philosophical and prose-like and this quality ensures that the lyric and dramatic do not really interact in the work. The philosophical nature of the quartets mean that there is little or no need for dramatic characters, movements or moments of theatre in them, and often even the lyrical tends to get lost in the midst of the philosophising. The emotion in the work is, like Eliot's description of a Lancelot Andrewes' sermon, "purely contemplative", and this contemplative nature removes any possibility of lyric-dramatic interaction in it (For Lancelot 21). Eliot had by now turned almost completely inward and chose to speak with his own lyrical voice rather than be submerged in the world of characters and voices that he used in The Waste Land and his poems before it.

\subsection{Conclusion}

With his formal entry into the world of the theatre Eliot continued his earlier experiments in attempting to combine the lyric and dramatic. The introduction of Christian elements in his plays, The Rock and Murder in the Cathedral allowed for the continuation of the lyric presence in these works. However, the nature of this interaction changed considerably thanks to the shift from primitivism and jazz in Sweeney Agonistes to Anglicanism. Eliot is not quite able to capture the same kind of excitement that arises out of the presence of the lyric in the dramatic after Sweeney Agonistes. Further, his reduction of the lyrical in his plays after the failure of the secular play The Family Reunion led ultimately to the vanishing of this lyricdramatic interface in his drama after The Cocktail Party. Simultaneously, we have a gradual reduction in the dramatic nature of Eliot's religious poetry before the nearabsence of the dramatic and the return to the greater Romantic lyric style in Four Quartets.

Thus, Eliot's attempts to work with an interaction of the lyric and dramatic in his creative writing which began around 1909 came to an end after The Cocktail Party in 1949. During these four decades, it had an impact on one seminal work of the era, The Waste Land, and another almost-forgotten but, in the context, equally important piece of writing, Sweeney Agonistes, besides affecting most of his other poetry and drama too. However, these pieces were two of the most important products of the lyric-dramatic interface in Eliot which was at the core of his creative 
energy and they ensured that he moved from working with the dramatic in poetry to experimenting with lyricism on the stage itself in a quest to invent a new poetic drama. 


\section{Conclusion: Tying up the Threads of the Lyric- Dramatic Interaction in Eliot}

Through my research I aimed to explore the nature of the lyric-dramatic interaction in Eliot's work and to trace the changing character of this interrelationship over the course of his career. While there is little doubt about the centrality of The Waste Land and Sweeney Agonistes to the examination of this interaction, there was almost no aspect of Eliot's literary life that the preoccupation with the lyric-dramatic interface did not colour. It must be noted, however, that the importance of this interaction varied at different periods in Eliot's career, and that it was at its peak just before and after the publication of The Waste Land. As we have seen, the need for such an interface was evident in Eliot's poetry much before The Waste Land and was the crucial aspect behind his movement towards lyric drama with Sweeney Agonistes. Eliot's adoption of the dramatic monologue form and his use of theatrical imagery in his early poems are manifestations of this need. In his criticism, this desire expressed itself though the discussion of the need for drama to return to a state of 'primitive' ritual, a condition where the lyric and dramatic co-exist. The need to blend the two elements came to such a pass that in some parts of The Waste Land Eliot's poetry is extremely close to drama.

At this point Eliot realized that he had to take the next step and plunge into lyric drama itself with Sweeney Agonistes. But Sweeney Agonistes is so lyrical that the dramatic tends to get subsumed in it and any desire that Eliot may have had to complete the work was lost with the arrival of Anglicanism into his life and the offer of The Rock as an opportunity for Eliot to reach out to a substantial audience via the Church. This shift provided Eliot with a middle path for his experiments in the lyricdramatic interface as he now had a ready framework of pageant and Mass within which to present his lyric dramas. However, by Eliot's own admission, the Christian plays turned out to be a "dead end" as far as his experimentations with verse drama were concerned. ${ }^{1}$ Eliot's return to secular drama with The Family Reunion exposed the artificiality and inadequateness of his Christian plays which had changed the way

\footnotetext{
1 "It was only when I put my mind to thinking what sort of play I wanted to do next, that I realized that in Murder in the Cathedral I had not solved any general problem; but that from my point of view the play was a dead end" (Eliot, On Poetry 79).
} 
he approached the interaction of the lyric and dramatic in his secular drama after Sweeney Agonistes. The lack of a middle path in the commercial secular theatre meant that he had to choose between the lyric and dramatic thereafter causing the two elements to split apart such that his drama was no longer really lyrical and his poetry no longer dramatic. Thus concluded the most fertile and exciting part of Eliot's literary and dramatic career.

Studying Eliot's creative output in this fashion allows us to adopt a more holistic view of his early writings on anthropology and his poetry before The Waste Land. It enables us to explore the significance of the dramatic nature of The Waste Land and the lyric nature of Sweeney Agonistes. Moreover, it allows us to retain a more objective view of Eliot's drama and to look at these works as much more than failed or relatively minor attempts by a successful poet to enter the theatre. It demonstrates that Eliot's early drama is, in fact, the result of his desire to conflate the lyric and dramatic, something he had already attempted in his poetry.

Having shown that The Waste Land and Sweeney Agonistes occupy the centre of such an interaction in Eliot's career, we must discuss what its presence entails for our reception of these two texts. The presence of the dramatic in The Waste Land, as we have seen, has been a given for a long time in criticism. The present thesis allows us to not just accept the poem as dramatic, but also to establish why it is so. The sense that the poem's dramatic elements arise out of Eliot's need to conjoin the lyric and dramatic in it gives us a different perspective on the work, allowing us to focus on things other than its sources or its intricate meaning and enabling us to view its dramatic nature as the culmination of the efforts of his earlier poetry.

The present thesis permits us to appreciate some of the reasons for the poem's uniqueness. An important part of the reason why The Waste Land was so revolutionary for its time was because of the way it included dramatic elements such as voices, dialogue and movement. These elements may not have existed in the poem without Eliot's desire for the interaction between the lyric and dramatic that had already manifested itself in his earlier poetry.

When we come to Sweeney Agonistes, the discussion of its lyricism and its place in the lyric-dramatic trajectory of Eliot's career provides it a centrality which has so often been denied it in the past. This centrality is not chiefly based on artistic merit but on the play's location at the heart of the lyric-dramatic interaction in Eliot's writing. Sweeney Agonistes could be, at once, Eliot's most radical work and his most 
important artistic 'failure'. It is radical because it takes the lyric-dramatic interaction in Eliot to an incredible highpoint, providing a unique mix of vaudeville, music-hall opera and African-American dialect in 'British' drama. The play's use of backchat and Sweeney's existentialist statements about the emptiness of life pre-dated Absurdist drama by more than a quarter century. ${ }^{2}$ Had Eliot taken the development of his career to its logical conclusion pointed to by The Waste Land and Sweeney Agonistes, he might have arrived at a highly experimental drama ahead of other, later playwrights. This is clear from the fact that several critics have pointed to Sweeney Agonistes as being ahead of its time. For instance, Worth calls the play a step in a "new theatrical direction" a direction which, she says, points us towards post-World War II theatre (154-155).

However, the play may have been left incomplete due to the nature of its initial publication (in parts) and on account of the playwright's later inability or unwillingness to maintain the lyric-dramatic interaction at the same intense level as in the first two fragments of Sweeney Agonistes. This condition was linked, perhaps, to Eliot's conversion which had a restrictive impact on the nature of the lyricdramatic interaction in his work. The incompleteness or 'failure' of Sweeney Agonistes marks the end of Eliot's most intense period of lyric-dramatic experimentation and the beginning of a more conservative, religious mode. To this extent, the play's 'failure' is of great significance to Eliot's creative oeuvre since it ensures the conventionality of his verse drama to come.

Nevertheless, the lyric-dramatic interaction in Eliot's work was crucial to his impact on the attempted revival of verse drama in England in the 1930s by others, including Auden and Christopher Isherwood. On a broader level, Eliot's desire to experiment with the lyric-dramatic in his work entailed a necessary mixing of 'high' and 'low' (or popular) cultures. To this extent, my work supports Chinitz's arguments about Eliot crossing the Great Divide between these two cultures and it questions decades of criticism that have kept Modernism separate from popular culture.

Given all this, it is imperative that we study this interaction through Eliot's career more closely. There is scope for further investigation into the nature of the

\footnotetext{
${ }^{2}$ See Spanos, W. V. "Wanna Go Home, Baby: Sweeney Agonistes as Drama of the Absurd" PMLA 85.1 (1970): 8-20 for a comparison of Eliot's play to Absurdist drama. However, we cannot really claim that Sweeney Agonistes had a direct influence on the Absurdists as the play was too fragmentary and too little known to make a difference.
} 
lyric-dramatic interaction in Sweeney Agonistes which would help us revisit the question of the importance of this fragmentary text. There is also scope for more theatrical workshopping of The Waste Land to further explore its dramatic nature and expand on its relation, in this regard, to Sweeney Agonistes. In the final analysis, while the lyric-dramatic interaction informed and influenced most of Eliot's literary career, the reduction of its intensity and its final disappearance from his work should, in no way, diminish its importance as a topic for further study. 


\section{APPENDIX: Workshop Reports}

Below are my workshop reports for the first ten theatre workshops that were conducted twice a week in August and September 2008 at Victoria University of Wellington for parts one and two of The Waste Land as part of work towards this thesis. There were two more sessions held after these ten workshops but those were pure rehearsals. These reports were written by me after every workshop.

\section{1) First Workshop Report}

Actors present: Haibo, Tom, Daniel, William, Hannah, Ting, Kristina, Nicola (6) However, since Kristina and Nicola joined in with the devising of the Sibyl scene they became actors. Later that week both Kristina and Nicola decided to join in the acting formally.

Crew present: Gregor, Patrick, Sugu, Paul, Kristina, Nicola.

Description: We started with warm-ups and some theatre games. Gregor then gave the group nursery rhymes to enact in pairs without using the words. After this, three groups of three actors each performed three Spike Milligan poems given by Gregor without using the words during the performance. The idea was to see how the actors dramatized different kinds of poems without the use of words. We then discussed what dramatic criteria allowed us to dramatize the poems we had worked with. We came up with three: movement, emotion through facial expression, and voices.

The Epigraph/Sibyl scene:

The actors were then split into two groups of four each and given the epigraph of The Waste Land, both in Latin/Greek and an English translation, and asked to dramatize these lines using the dramatic criteria we discovered so far. They were allowed to decide whether they wanted to use the words in Latin/Greek with or without the English translation or if they wanted to dump the words altogether and use only 
movement. They were not given any background about where the lines came from and what they could probably mean.

After 15 minutes or so, the groups performed. The first performance involved Hannah kneeling frozen on a chair as the Sibyl while Ting stood on a second chair behind her and silently put her hands around Hannah's face in a protective gesture. Dan stood to one side and narrated the lines while Haibo went round and round on the floor on his haunches almost like an animal, staring at the Sibyl, circling her, and seemingly mocking her with his question “What do you want?" Hannah's answer was underplayed: "I would die". The second performance involved Gregor and Tom as two naughty boys at play who put Kristina (as the Sibyl) into a cardboard box and moved it around while asking her the question. She then curled up inside and said: "I would die".

The groups then interchanged personnel. The new groups were asked to perform the same scene in a different way now. Thus, about twenty minutes later, a third performance was devised which used only movement with Nicola as the Sibyl in the centre of a circle and three actors pulling her from all sides till she collapsed. The fourth and final performance of the night added lines which dealt with children at play. Hannah and Tom played a game on the floor, while Ting (as the Sibyl) wished to join them. However, Hannah and Tom excluded Ting from the game. Daniel, who played a music-hall master of ceremonies kind of narrator during this scene miming a microphone in his hand, then asked Ting what she wanted. Ting then replied: "I would die" (because she is excluded from the children's game).

With that we thanked everyone for the work done. After the final performance the group wanted to know a little bit more about the Sibyl. I told them that she was an ancient prophetess and mentioned that Eliot took the lines from Petronius' Satyricon, which was written about 2,000 years ago. I did not give them any more information. We called it a wrap for the day.

My comments on first workshop:

First performance: I liked the image of Hannah frozen up on the chair and a cage created for her by Ting while Haibo goes around (Hannah, Ting, Haibo, Dan) 
Second performance: The image of the Sibyl in a box as a cage was also interesting and the little boys playing their games around it. However it did not seem to work as well as the other scenes.

Third performance: The third image of the cage as people dancing or moving around the Sibyl without words seemed I guess the most appropriate movement of all. However, no words were used which I thought took away from the poetry.

Fourth performance: The fourth - of Daniel acting almost like a music-hall Master of Ceremonies and Hannah and Tom not allowing Ting (Sibyl) to be part of their game was good fun to watch but I think it was not really appropriate to the lines, especially because additional, and unconnected lines were added to it (Dan, Hannah, Tom, Ting).

\section{2) Second Workshop Report}

Actors present: Tom, Daniel, Nicola, Kristina, Hannah, Ting, Gillian (7)

Crew present: Patrick, Sugu, Ralph

\section{Introduction:}

I welcomed the cast and crew back and introduced everyone to Gillian and Ralph. I talked a bit about the process over the next two to three weeks. Then I mentioned the four dramatic criteria that we had brought up during the first workshop. These were movement, emotion, facial expression (linked to emotion) and a narrative element. I also raised some dramatic criteria that we did not bring up and that I thought were present in some way during the first workshop. These included direct speech, the use of voices, imagery, time and characters.

Revisiting the epigraph/Sibyl scene:

I asked the actors to use the dramatic criteria they felt were useful to think about while working on the Sibyl scene as one big group. After the first workshop, I thought the best thing to do for this scene was to use the movement from the third performance and use Dan as the music-hall Master of Ceremonies, but the actors had 
other ideas in the second workshop. Since they asked what I thought of their performances on Tuesday, I told them I enjoyed the movement from the third performance but was not against the idea of the Sibyl frozen on a chair either.

The actors decided to merge the movement of the ring of disciples from the fourth performance around the Sibyl with the frozen image of the Sibyl on the chair from the first performance. Dan took over the role of narrator in this scene. However, he did not use the 'microphone-in-hand' image that he had used during the first workshop. Daniel decided to only say "Nam Sibyllam" at the beginning gesturing at the Sibyl, while he stood within the circle next to her. The children or disciples (four of them) going round in the circle kept saying "hanging in a cage" several times, before Dan gestured to Nicola (one of the children in the circle) to step forward to the Sibyl and ask "What do you want?" The Sibyl (Hannah) then responded, "I would die". There were questions about how loudly the actors wanted to say "hanging in a cage". They also all decided to collapse and 'die' at the end of the scene except for Hannah and Ting (who was playing the cage). The circle moved anticlockwise. Later, the actors decided they would hum eerily as a group at the start of the scene. They hummed something close to an "Om" sound from Hindu religious scriptures before Dan started with "Nam Sibyllam" and the group muttered "hanging in a cage".

April is the cruellest month:

First idea:

After an hour of working quite satisfactorily on the Sibyl scene, we decided to move on to the poem itself beginning 'The Burial of the Dead' (Part One). The actors decided that since they were all lying 'dead' on the floor [except for the Sibyl (Hannah) and her protector, Ting], that the Sibyl would be the first to get down off the chair and move forward and say "The Burial of The Dead" directed at the audience. There was some debate about whether the Sibyl or her protector was to carry off the chairs into the wings or if the chairs should remain centrestage. There was no resolution of this debate on Friday. The Sibyl then said the first two lines "April is the cruellest month breeding lilacs out of the dead land" and went to where Dan was lying 'dead' and 'resurrected' him with a touch. The first version of this scene was tried out with each actor, except for Ting and Hannah, being woken up and then the actor that was woken up moving to another 'dead' actor and waking 
them up on their individual line. This was a bit slow and protracted and the words seemed to be getting lost. While the actors felt that the movements were too slow, they were not too concerned about the words, perhaps because they could not listen to things from an audience's perspective. They were more engaged in criteria linked to movement and time. This idea was also modified a bit with the actors deciding they would rise and collapse to the floor again almost immediately in a sort of cycle of the seasons. However, I felt that excessive rising and falling in a short span of time may detract from the overall picture and might seem too much, too soon. It looked a bit strange that the moment they rose they were already beginning to wither and die. It might work if we get the timing spot on. But I think it may be very difficult to get this part of the idea right.

\section{Second idea}

They wanted to quicken the pace of the entire scene and so they tried giving the first four lines to the Sibyl who was supposed to say them while moving around a floor strewn with 'dead bodies'. This was followed by three lines from the Sibyl's protector (Ting). During Ting's lines the 'dead bodies' magically spring to life starting with the line "Winter kept us warm" so that everyone was left standing at the end of Ting's third line. While the pace of the rising and the entire scene was much quicker in this context, I was not too sure the first part of the scene with the Sibyl walking among the 'dead' worked too well. We decided after an hour that we had enough of the opening scene of the poem itself by then and should move on and come back to it later.

\section{Countess Marie:}

I now gave the group the lines where Countess Marie features. Each actor read the lines out once. The actors wanted to know who Countess Marie was and who she was talking to. In a minute I told them that she was a German aristocrat and niece of the Austrian Empress whom Eliot might have met in 1914 in Germany. I also mentioned that she had two cousins, both Archdukes, who both died violently. Kristina came up with an idea for playing this scene. She suggested that instead of one Countess Marie, we should have three. 
First idea:

The oldest Marie would be the one doing most of the lines. Gill took up this role. Nicola became the Marie who sat at the café with a gentleman at stage right (Dan), while Kristina was the Marie on the slope, sledding downhill with her archduke cousin (Tom) at stage left. Gill spoke the words up to "Hofgarten". Dan then decided to say the German "Bin gar keine Russin stamm aus Litauen echt deutsch" with Nicola providing a translation. Gill picked up from the line after this "And when we were children" continuing till the end with Kristina and Tom providing the action for the sledding. Kristina did not speak at all, but Tom did say "Marie, Marie hold on tight" before Gill took over again. Hannah took no part in this scene.

\section{Second idea:}

While the group seemed to like the first idea, they also wanted to try with Kristina speaking the part from "And when we were children" going up to "in the mountains there you feel free". I personally felt that while Kristina was saying this bit well it detracted from the action of sledding that she was doing earlier and did not allow her to concentrate on the physical which was much better when she did not speak at all. There was still more we could have tried with the scene, when we had to wind up because it was $9 \mathrm{pm}$.

\section{My comments on second workshop:}

I think the Sibyl scene is beginning to come together nicely, though there are still issues about language and voice that may need resolving there. The opening section of the poem itself dealing with the seasons was difficult for the group to think about. It probably gave the most difficulty of the three scenes we have tried so far. The actors were thinking about transitions between scenes almost straight away. They found that the last movement of the previous scene (dying in the epigraph) helped them to start the next scene. So they saw a natural connection between the scenes linked to movement.

However, they chose to see the Countess Marie scene in isolation. They were more comfortable with this scene. One difficulty I thought that might occur was whether the actors could be clearly seen by an audience when they fall and die on the floor or 'sled' on the floor. I do not want to use rostra or anything that clutters up the space. I want to give them as much space as possible to do what they want 
movement-wise, but I also asked them to think about how much space they would really require. I also do not want a floor space that would hurt them since they do collapse onto the floor quite frequently. I thought that collapsing twice was a bit too much and could be curtailed - so we can collapse once instead of twice in a matter of minutes.

What we achieved in the second workshop and brief plan for third workshop On the whole, I was happy with the amount of work we got done and how we had enjoyed ourselves getting into the poem on the day. I think we were able to apply some of the dramatic criteria to the scenes, but I also felt some criteria were not used or were totally forgotten. I think I should bring these up when we revisit the opening scene and Countess Marie on Tuesday. I will not return to the Sibyl scene during the third rehearsal. I also think that I should let them know more about why I want to undertake this project which I will talk about to some extent at the start of the next workshop. My current plan for the next workshop also includes moving to the Madame Sosostris sequence (11. 43-59) in the second half of the day and if possible the 'Unreal city' section which ends part one (11. 60-76).

\section{3) Third Workshop Report}

Actors present: William, Dan, Tom, Hannah, Ting, Kristina, Nicola

\section{6- $6.15 \mathrm{pm}:$ Introductory talk}

First we talked about the dramatic criteria we came up with last week and how these were central to what we were doing in the workshops. I gave the cast a printout of a list of nine dramatic criteria that we had come up with in the previous week. The criteria included movement, emotion, facial expression (linked to emotion), a narrative element, direct speech, voices, imagery, time and characters.

\subsection{5-7:45 pm: Countess Marie and 'April is the cruellest month' revisited}

For the first part of the workshop we stayed as one big group revisiting first the Marie scene and then going back to the beginning of the poem starting at "April is the cruellest month". 
Then we did the Marie scene in a similar manner to the way the group worked it out at the last workshop as Matthias from Germany was there to help us pronounce the German lines. Fiona took on Gill's role as the main Marie since Gill was no longer available. William and Kristina played the sledding couple as Tom was late. Hannah and Dan played the couple in the cafe. There was some discussion about how Hannah should react haughtily to something Dan says to her before she says "Bin gar keine Russin" as if her reply is in response to an offensive question from Dan. This, the actors believed, would show the class difference between Tom (Eliot) and Hannah (Marie).

Fiona read most of the Marie lines while touching each couple to activate them and pass lines on to them. She tagged Hannah before Hannah said 'Bin gar keine Russin ... echt deutsch'. Kristina did not say any lines while William said "Marie, Marie hold on tight!" I thought that Fiona read the lines too quickly and that she missed a beat / change of emotion before the last lines "I read much of the night ..."

The actors then blended the scene with the previous scene from "April is the cruellest month" with Hannah doing the lines till "with spring rain" and everyone except Ting lying 'dead' all this time. Ting then picked up from “winter kept us warm" and while she spoke the rest of the cast started rising from the dead, each at different times till they were all nearly standing at 'with dried tubers'.

Dan thought that the transition time would best be covered by beats. During the first beat the sprouted human beings would break from their individual sprouting to form the couples and take up their position for their next scene. At the next beat they would freeze until the main narrator - Marie came in and un-froze them by narrating her lines. Paul, who was in charge of sound, mentioned to me that he might bring his keyboard and provide live sounds for the beats to help the transition.

At the end of the process, we discussed some of the dramatic criteria that may have come up. I asked the cast to think about narrative and whether Fiona (Marie) needed to touch the other actors in the Marie scene or not. I also asked them to think about the characters that might have emerged. They said that besides the Sibyl (Hannah) in the opening scene, we have the Sibyl's assistant or cage (Ting), a chief priest who acts as a kind of narrator (Dan), and four of Sibyl's disciples / children who have collapsed following the epigraph and now slowly rise in the opening scene. 
In the Marie scene, the cast thought that they had three different Maries - the older Marie who is recollecting stuff (Fiona), the Marie (Hannah) with Eliot (Dan) at the café and the Marie (Kristina) who is on a sled with her Archduke Cousin (William). So they were thinking of characters which helped us see which roles emerged.

7:45-8:30 Devising and first performances of Madame Sosostris and Unreal City sequences:

Tom arrived at 7:45. Now, I split the actors into two groups of four and gave the Sosostris sequence to Group A (Hannah, Dan, Fiona, Nicola) and the Unreal City sequence to Group B (comprising William, Tom, Kristina and Ting). Group A seemed to be moving much faster with the Mme Sosostris scene than Group B who was having trouble working with the Unreal City sequence.

Ultimately, Dan and Hannah from Group A played a very comic and quite brilliant Madame Sosostris scene. Dan acted as Sosostris' announcer who moves comically around the room, at times even involving an audience member directly by looking at her closely and getting her attention. I thought that this aspect of audience interaction was something we could think about as another dramatic criterion. It was as if the audience themselves were Sosostris' client and Dan was the go-between for Sosostris and her client. Hannah (Sosostris) called out her cards while holding out A4 size sheets. I think that having blank sheets all the way for the cards would be quite nice, especially when we come to the bit when she says "this card which is blank". We have to think of props as being part of the drama of the poem and Sosostris' cards definitely bring that up. All the while, Dan was acting out the different cards that Hannah drew. Sometimes, quite comically, Dan would be late in acting out one of the cards (for example the Wheel!) and he would try to play catch up. The sense of timing was crucial then to the comic nature of this scene. However, what I felt it missed was the possibility of working on creating some of the fear that goes with "fear death by water". On the whole, though, the performance was excellent, with Dan actually reading out one of the cards when Hannah forgot to read them. Hannah used a Cockney-like accent for the scene.

Group B decided to give us two versions of the Unreal City sequence as they were unsure which worked better. They were caught up with the idea of the clock of 
St. Mary Woolnoth and the characters who they thought were slaves to time. William did ask me where St Mary Woolnoth was and I told him it was a church in London. Tom played narrator for the lines going from Unreal City up to just before the word "Stetson". During this time the three other actors formed a queue in front of Tom who was I think perhaps between upstage centre and midcentre. The three kept checking their watches at every tick of the clock seemingly before dropping their head to one side and looking sideways at the audience when Tom said "with a dead sound on the final stroke of nine". William took over with the word "Stetson" breaking off from Tom's narrative. William's performance was mocking and funny and contrasted with Tom's dead-pan narrative which had lasted up to that point. The actors believed that the scene was supposed to be played in a mocking way. They were not sure about who or what Stetson was. They did ask me about the use of the word "dog" in the line "keep the Dog far hence" and I said it was a line from Webster.

Group B's second version of the Unreal City sequence involved Tom doing all the lines and pointing out to Stetson (William) who was in the middle of the line of three actors, but who did not seem to change too much in terms of movement when pointed out.

8:30-9:00 Devising and second performances of Madame Sosostris and Unreal City sequences:

We now changed the groups around so that Group A had the Unreal City scene and Group B had the Madame Sosostris scene. However, since Nicola had left at 8.30, I put William into Group A. Thus Group A now comprised William, Dan, Hannah and Fiona, while Group B included Kristina, Ting and Tom.

Group A had one of the actors (William) narrate some of the initial lines of Unreal City, before the other actors came up from behind with individual lines oneby-one to mock him. The actors thought that they would do the bit as a sarcastic response to the whining of the narrator about things going bad. I thought that while the idea was an intriguing one, it may have been a bit too much for all of the rest of the actors to take up the same sort of tone. What I enjoyed was the pointing out of Stetson (William) by each one of the rest of the actors who trapped Stetson in the 
centre on this occasion. It may be worth a try to see the effect of each actor taking on a different emotion while doing so.

Group B seemed a bit stumped with what to do with the Madame Sosostris scene as we were running out of time. Ultimately, they decided to place an empty chair backing the audience and Sosostris (Kristina) facing us and drawing cards. Ting who was crouching behind Sosostris' chair narrated the first couple of lines, before Tom began to enact the different cards. It seemed as if some of the elements of the previous Sosostris performance were used, though this performance was quite a bit more static. Sosostris seemed to work better with Dan and Hannah for some reason.

I think at the end of it all, Dan told me that he found the Sosostris scene easier to do because it lent itself to drama so easily. While I tended to agree with him there, the difficulties faced by Group B in dramatizing Sosostris may have gone against what Dan said. However, I still think that the Sosostris scene might have been the most amenable when it came to performing poetry as drama in The Waste Land so far. I am also inclined to think that the very transitions from the end of the opening scene into Countess Marie are quite dramatic. Both the opening scene and Marie have their problems with movement, though I think that the Marie scene was much easier for the actors to dramatize. The Unreal City scene raised some issues and seemed problematic. The epigraph also does lend itself to drama quite well I think. I would still go with Sosostris as the scene from the actual poem itself which comes closest to drama for me so far, especially with Dan and Hannah performing it.

\section{4) Fourth workshop report}

Actors: 6:00 Ting, Tom, Nicola, 6:45 Dan, 7:30 Hannah

\section{What are the roots that clutch...Oed und leer das Mer}

We had only three actors at the start of the rehearsal. Kristina was sick. William and Fiona could not make it because of personal reasons. Dan came in later at 6:45 and Hannah arrived around 7:30 due to work. So we started off with three.

After a brief warm-up, I gave Tom, Nicola and Ting the lines from Part One which we had not tackled before that is from "What are the roots that clutch" (1. 19) to "O'ed und leer das Meer" (1. 42) to dramatise. While they were having problems 
figuring out what to do, Gregor who was present for this workshop, wanted to put them through some movements so they could start to move instead of think too much. He got Tom and Nicola to say the lines (from 1.19 to 1.30), splitting them between themselves while having a wrestling match, and later a tickling match. This got the actors thinking about movement and they used the same splitting of lines but to new movements when they tried it on their own later.

Nicola entered first in silence and Tom followed asking almost angrily 'What are the roots that clutch, what braches grow / Out of this stony rubbish?' establishing himself near mid-centre, close to where Nicola was. Thereafter Nicola tried to drag Tom, who appeared forlorn and did not seem to want to move, away from the centre as she said the lines: 'Son of man, / you cannot say, or guess, for you know only / A heap of broken images, where the sun beats, / And the dead tree gives no shelter, the cricket no relief, / And the dry stone no sound of water.' Nicola ultimately succeeded in dragging Tom somewhat towards downstage left. Tom then picked up the rest of the lines starting "Only / There is shadow under this red rock, (Come in under the shadow of this red rock), / And I will show you something different from either / Your shadow at morning striding behind you / Or your shadow at evening rising to meet you; / I will show you fear in a handful of dust.' While saying these lines, Tom first gestured towards an imaginary rock at upstage-centre / mid-centre. There was a bit of encircling of Nicola by Tom with the lines on the shadow following one around. Tom then knelt down and picked up "a handful of dust" to throw on the ground while Nicola watched. Gregor suggested the handful of dust gesture and the pointing to an imaginary rock.

Nicola then said the first couple of lines from the 'Hyacinth girl' sequence: "You gave me hyacinths first a year ago; / They called me the hyacinth girl'. Ting then stepped in and said the lines from "Yet when we came back, late from the hyacinth garden" up to "the silence". Since Dan had now arrived, I asked Ting and Dan to work together on the hyacinth girl sequence, while Tom and Nicola worked on the Ezekiel sequence.

Tom and Nicola took a break now, while Dan and Ting performed the Hyacinth girl sequence. Dan and Ting had decided to divide the lines thus:

Ting: You gave me hyacinths first a year ago;

They called me the hyacinth girl 
Yet when we came back, late, from the hyacinth garden,

Yours arms full....

Dan: .....and your hair wet, I could not

Speak, and my eyes failed, I was neither

Living nor dead

Ting: $\quad \ldots$ and I knew nothing

Dan: Looking into the heart of light...

Ting: ...the silence

While they said these lines Dan almost had his back turned to Ting, who was trying to get his attention but failing. They were mid-centre for this piece. Gregor made a suggestion that Dan could try sitting on the floor for the scene, while Ting stood.

We then tried to put things together as I asked them if they thought it was possible to merge the sequences using all four actors present. The actors felt it would be better if I sang the German lines from Wagner in between the sequences. When Tom and Nicola finished their sequence which ended with Tom down on one knee releasing a 'handful of dust' and Nicola standing between downstage centre and midcentre, I sang "Frisch weht der Wind [...] wo weilest du?" During the song, Dan walked slowly on to stage and sat down on the floor at downstage right at a 45degree angle with his legs pointed out and his knees raised. Ting then appeared and stood behind Nicola (Gregor's suggestion) while the two girls shared the lines: "You gave me hyacinths first a year ago; / They called me the hyacinth girl". After this Nicola and Tom exited and left the stage to Ting and Dan. Ting then moved towards Dan saying the lines: "Yet when we came back, late, from the hyacinth garden, / Your arms full [...]" Dan abruptly interrupts with "[...] and your hair wet, I could not / Speak, and my eyes failed, I was neither Living nor dead". During Dan's lines, Ting moved away from Dan and stopped looking at him. Dan never looked at Ting but stared off into the distance. Ting came back to say to him "... and I knew nothing". All these movements seemed to come naturally based on where they were placed. As Dan laconically said: "Looking into the heart of light", Ting who was by 
now walking away towards an exit at upstage left, stops almost mid-centre and said "the silence" before moving on. I sang "O'ed und leer das Mer" as she exited. Thus, we had come up with a way of doing this section with four actors and we decided to leave it there and work on the 'Unreal City' sequence at the end of Part One as Hannah had joined us by now.

\section{Unreal City revisited}

I decided to revisit the 'Unreal City' sequence as I felt that it needed work. I told the actors that I was quite happy with Dan and Hannah's handling of the Madame Sosostris sequence on Tuesday and that we could perhaps leave it there for now.

The group decided to try out Tom as the narrator for the Unreal City sequence. Based on what was done during the first performance of the sequence on Tuesday, they created a line of citizens in this order: Ting, Hannah, Dan, Nicola. The citizens dragged their feet and started walking as if in a chain-gang when Tom started off with "Unreal City / Under the brown fog of a winter dawn". Tom was standing between upstage centre and upstage left when he said these lines, but he was being blocked by the 'chain-gang'. Gregor suggested that Tom stand on a chair when he said the lines. With Tom on the chair the citizens who were tied to the clock (they kept checking their 'wristwatches' every few words) kept walking mechanically across the stage, from downstage left to downstage right. When Tom said: "With a dead sound on the final stroke of nine", the workers all stopped and looked at an imaginary clock. Initially, they wanted to look backward towards upstage right for the clock. However, I felt this was not aesthetically correct as their faces were hidden from audience view then. I suggested they look outward and Gregor suggested they look outward and towards the light and sound control room which was out in the audience from downstage left. This way their faces could be seen during the sequence to follow. Tom then stepped down from his chair and confronted Dan (who by now was at downstage centre) with "Stetson!" pulling him backward out of the crowd at the same time. Tom threw the lines in a partly sarcastic and in-your-face manner at Dan, while the rest of the crowd started moving offstage towards the downstage right exit. When Tom had finished 'Or with his nails he'll dig it up again!' Dan initially stepped forward towards the audience and said 'You! Hypocrite lecteur! - mon semblable, - mon frère!" There was some debate about whether this last line should be thrown at the audience or at Tom or both. I told Dan to do what he 
thought was best for him. Dan then decided to grab hold of Tom close to mid-centre and drag him forward with his arm around the shoulders of a reluctant Tom, while accusing Tom with "You! Hypocrite lecteur!- mon semblable - mon frère!" At the end both Tom and Dan were facing the audience at downstage centre. I decided to leave it there and revisit it during the next workshop when I hoped to stitch together as much of part one as possible.

We had realized by then that we had done Part One of The Waste Land in one way or the other through the different sequences and it was now time to call it a day. While we did not focus on dramatic criteria directly today because of the lack of actors at the start, I think I will focus on it during workshops next week after we stitch part one together. My plan for the next workshop includes revisiting the section from 'What are the roots that clutch' up to 'O'ed und leer das Mer', and then working on trying to run all of Part One if possible before the night is out. I am not sure if the last would be possible, but I feel it will be very important to work on transitions before we get there.

\section{5) Report on Fifth Workshop}

Actors present: Seven - Ting, Hannah, Nicola, Fiona, Kristina, Dan, Tom

My objective for this workshop was to work on transitions between scenes in Part One and then run all of Part One uninterrupted. After some warm-ups, we decided to progress scene-by-scene, using the settings that the actors had come up with. I told the actors that we would work on individual scenes in order and try to iron out problems related to transitions. Thus, they performed the six scenes going from the start to finish of Part One and including the epigraph.

I shall list the six scenes with the actors and their possible roles mentioned per scene. I shall also mention how many actors in total we used per scene. Besides this I shall give a description of each scene as it was finally performed on the day. We did a run without any music after an hour. The performance without music lasted for nine minutes in total. We then broke down the scenes again and worked with some music provided by Paul where possible. We did not have the time to run the entire part together with music once more, but I feel with music it may extend to 
about 10-12 minutes. The descriptions I give of each scene below are of the scenes as they were in the run, performed around 7.30 on the day. Where the description of music used is added in points to things we changed or added after listening to Paul's music between 7.30 and $9.00 \mathrm{pm}$. The changes that came with music were only in the 'Unreal City' scene.

1) Scene One - The Sibyl scene (epigraph)

Actors required:

The Sibyl of Cumae - Hannah

The Sibyl's Cage / Assistant - Ting

The Sibyl's Chief Priest / Narrator - Daniel

Disciple 1 - Nicola

Disciple 2 - Fiona / William

Disciple 3 - Tom

Disciple 4 - Kristina

Total actors required: Seven

(The names of the characters came from the actors themselves).

\section{Description:}

The actors stuck to what we used last for this scene (i.e. during the second workshop). They had a ring of four people around the Sibyl with the Sibyl kneeling on a chair placed centre-stage. Ting (Sibyl's Cage) stood on a chair placed behind the Sibyl's chair and put her hands over the Sibyl's head. Dan took over the role of narrator or chief priest. He said only say "Nam Sibyllam" at the beginning, gesturing at the Sibyl, while he stood within the circle next to her. The children or disciples went round in a circle saying "hanging in a cage" several times, before Dan gestured to Nicola (one of the actors in the circle) to step forward to the Sibyl and ask "What do you want?". Hannah then responded "I would die". Except for Ting and Hannah, all the actors collapsed and died at the end of the scene. The circle moved anticlockwise. The actors also hummed eerily as a group at the start of the scene.

Music: Paul tried some music he had composed this time with the scene but it did not seem to work. He later tried some other music which may work. 


\section{Transition:}

This scene moves easily into the next because most of the actors are 'dead' on the floor and they need to rise in the next scene.

2) Scene Two - The Opening scene of the poem [From 'April is the cruellest month' (1.1) to 'Feeding a little life with dried tubers' (17)]

Actors required:

Narrator 1 - Hannah

Narrator 2 - Ting

Corpse 1 - Dan

Corpse 2 - Nicola

Corpse 3- Fiona / William

Corpse 4 - Kristina

Corpse 5 - Tom

Total actors required: Seven

Description: The actors decided to stick to what they last used for this scene (i.e. the second idea for the scene during rehearsal 2 and what they did during rehearsal 3). Hannah said the lines from 'April is the cruellest month' up to 'Stirring dull roots with spring rain' (11. 1-4). Hannah now said the lines starting from the time she got down from her chair and started moving between Dan and Nicola to downstage left. Ting then got down from her chair and said the lines starting from "Winter kept us warm” (15) going up to 'Feeding a little life with dried tubers' (17). As she said this Ting walked to downstage right, moving between Nicola (downstage centre) and Fiona or William to balance Hannah's position on the floor. While Ting spoke the corpses began to 'sprout'. The actors began to rise like crops growing out of the ground, till they were all almost fully 'grown' at scene's end.

Music: Paul played us a recording of some keyboard music which he had composed. This seemed to suit the scene very well. The group definitely felt that allowed the dead people to come to life more easily, and that the timing of the sprouting had improved with the help of the music. 
Transition: The actors were freezing at the end of Paul's music for this scene (music fades out). Kristina was clapping her hands to get them to break the freeze and get into position for another freeze before the 'Countess Marie' scene. Paul thought this transition could be done through music (I thought lights could also be useful here to avoid the clap). After Kristina's clap, Fiona, Ting and Nicola get off the stage. Of these three, Fiona has to return for the next scene. But before that Hannah and Dan get together at centre-right for the café area of the next scene. Dan, I think, repositioned the chairs from centre-stage to centre-right at right angles to each other, while Hannah froze just before she sits in the café. Meanwhile, Tom and Kristina got into a 'sledding freeze' at centre-left for the next scene.

3) Scene Three - Countess Marie

Actors required:

Main Marie - Fiona

Marie in the cafe - Hannah

Marie on the sled - Kristina

Archduke, Marie's cousin - Tom/William

Eliot / Male companion of Marie in the café - Dan

Total actors required: Five (Ting and Nicola are offstage for this scene)

(Kristina said that Marie's male companion in the café was Eliot. The actors also decided that it was Marie's cousin, the archduke, who was in the sled with her).

Description: The actors pretty much stuck to what they did last time for this scene i.e. using Fiona as a present-day Marie who is recollecting her past and who gives us most of the lines. Fiona entered from upstage-right and she starts "Summer surprised us". On Fiona's line: "and drank coffee and talked for an hour" she touched Hannah and activated the couple in the café (I still did not think the touching was necessary though I did not let the actors know about it). Hannah then said: "Bin gar keine Russin ... echt Deutsch” in a haughty manner and sat down. Dan mocked her and said in English to the audience: "I am not Russian. I am Lithuanian. Pure German" before settling down on his chair himself. Fiona then continued her lines and moved to centre-stage (sometimes she went to upstage-centre which I felt was too far in) to say: “And when we were children". Tom intervened with his archduke's line "Marie, 
Marie hold on tight" while holding on to Kristina from behind in their positions on the 'sled' (on the floor). Fiona finally crossed to downstage left to finish her last line: "I read much of the night and go south in the winter". She did not touch the second couple at all.

Music: Paul played 'Meditation' from Thais, an opera by Jules Massenet first performed in Paris in 1894. The music seems to fit the scene as it is tender and evokes memory. The actors felt it suited the scene well. This piece would have probably been well known and loved in the Paris of 1910 when Eliot was in the city.

Transition: The actors just walked off stage here leaving an empty stage. Nicola entered in silence thereafter for the next scene and Tom followed with his lines.

4) Scene Four - "What are the roots that clutch" up to "O'ed und leer"

Actors required:

Narrator 1 - Tom

Narrator 2 - Nicola

Hyacinth Girl - Ting

Hyacinthus / her male lover - Dan

Sailor lad/Shepherd from Tristan und Isolde (singing offstage) - William/Patrick Total actors required: Four (plus one offstage voice. Hannah, Kristina and Fiona are offstage).

Description: The actors decided to stick to what they did for the fourth rehearsal for this scene. Nicola entered first and Tom followed asking almost angrily "What are the roots that clutch, what braches grow / Out of this stony rubbish?" establishing himself near mid-centre, close to where Nicola was. Nicola tried to drag Tom, who appeared forlorn and did not seem to want to move, away from the centre as she said: 'Son of man, / you cannot say, or guess [...] And the dry stone no sound of water.' Nicola dragged Tom somewhat towards downstage left. Tom then picked up the rest of the lines starting "Only / There is shadow under this red rock" going up to "I will show you fear in a handful of dust". While saying these lines, Tom gestured towards an imaginary rock at upstage-centre / mid-centre. There was a bit of encircling of 
Nicola by Tom with the lines on the shadow as they followed one another around. Tom then knelt down and 'picked up a handful of dust' to throw on the ground while Nicola watched. I now sang "Frisch weht der Wind [...] wo weilest du?" During the song, Dan walked on to stage and sat down on the floor at downstage right. Ting then appeared and stood behind Nicola while the two girls shared the lines: "You gave me hyacinths first a year ago; / They called me the hyacinth girl". After this Nicola and Tom exited and left the stage to Ting and Dan. Ting then moved towards Dan saying the lines: "Yet when we came back, late, from the hyacinth garden, / Yours arms full [...]" Dan abruptly interrupted with "[...] and your hair wet, I could not / Speak, and my eyes failed, I was neither Living nor dead and I knew nothing". This last phrase was a change from last time as we decided not to split the line and give "and I knew nothing" to Ting, since Dan was uncomfortable with the split there. Instead Ting said "Looking into the heart of light, the silence" all by herself. During Dan's lines, Ting moved away from Dan and stopped looking at him. Dan never looked at Ting but stared off into the distance. Ting said her last lines while walking away towards an exit at upstage left. She stopped almost mid-centre and said "the silence" before moving on. I sang “O'ed und leer das Mer” as she exited.

Music: The actors told Paul that it would be nice to get desert sounds - like the sound of crickets, or vultures - for the first part of this scene with Tom and Nicola. I provided some live music through the singing of the German lines from Wagner which I would rather give to William to sing. For the Hyacinth girl section, Paul played 'Clair de Lune' by Debussy which was published as part of the composer's 'Suite Bergamasque' (1903). Debussy's music was written in direct response to French Symbolist poet Paul Verlaine's poem 'Clair de Lune' ('Moonlight') which was published as part of the poet's collection Fetes Galantes (1869). The actors felt the music fitted the section quite nicely.

Transition: At the end of this scene Dan was the only actor left on stage, sitting at downstage right. Dan did a back flip on the floor to magically transform himself into a happy-go-lucky assistant to Sosostris for the next scene.

5) Scene Five - Madame Sosostris 
Actors required:

Sosostris - Hannah

Sosostris' assistant / Narrator - Dan

Total actors required: Two

Description: Dan acted as Sosostris' announcer who moved comically around the room, even involving an audience member at one stage by offering her a card. Dan started off alone on stage saying "Madame Sosostris, famous clairvoyante ... with a wicked pack of cards". Hannah then drew the curtains aside to make a dramatic appearance as Sosostris saying "Here is your card". The audience were Sosostris" clients and Dan acted as the go-between for Sosostris and her client. Hannah (Sosostris) did not use the A4 size sheets this time, but mimed drawing cards. All the while, Dan acted out the different cards that Hannah drew. Dan decided to make the sign of the cross for the man with three staves; he did a cartwheel for the Wheel and pretended to piddle on stage for the one-eyed Merchant. Dan said the line "I see crowds of people walking round in a ring". Hannah grandly said "thank you" as if she was ending a performance (which she was!) Dan said the last bit: "one must be so careful these days" and they both exited. Hannah used her Cockney dialect for this scene.

Music: Paul talked about using Middle Eastern or other music for the start of this scene, but we did not get to nailing it down to any one thing. He did play some music (this sounded Indian) though for this scene which we felt might be more useful for the Sibyl scene. We did not have time to try it with the Sibyl scene but we might do that later. Paul will look for some other music for Sosostris if necessary.

Transition: After the Sosostris scene the stage is empty again. I think Dan and Hannah should exit stage left as they have to come in again with the Unreal City crowd.

6) Scene Six - Unreal City

Actors required:

Eliot / Narrator - Tom

Stetson - Dan / William 
Worker 1 - Kristina

Worker 2 - Ting

Worker 3 - Hannah

Worker 4 - Nicola

Worker 5 - Fiona

Total actors required: Seven (though we could reduce the number of workers and bring it down to six actors on stage in all)

Description: The group decided to stick to what they did in the fourth workshop but made a few changes as we went. Tom was the narrator for the sequence standing on a chair between upstage centre and upstage left. The line of citizens was led by Kristina this time as she had a plan to use Paul's sound effects to aid the movement of the workers (Paul had come up with the sound of a chain-gang moving). Kristina decided that the workers could take two steps for the first two beats of the sound and then check their watches on the third beat. The group also decided to sigh when they checked their watches. The citizens dragged their feet and started walking as if in a chain-gang when Tom started off with "Unreal City / Under the brown fog of a winter dawn". When Tom said: "With a dead sound on the final stroke of nine", the workers all stopped and looked out above the audience at an imaginary clock. Tom then stepped down from his chair and confronted Dan with "Stetson!" pushing him forward out of the crowd at the same time (this push forward was a change from the push backward into the stage that Tom earlier used). Also the crowd stayed where it was till the end of all the lines. When Tom had finished "Or with his nails he'll dig it up again!' Dan decided to step backward and grab hold of Tom close to mid-centre and drag him forward with his arm around the shoulders of a reluctant Tom, while accusing Tom with "You! Hypocrite lecteur! - mon semblable - mon frère!" At the end both Tom and Dan were facing the audience at downstage centre.

Music: Paul had the sound of a chain-gang moving and this helped the crowd to time their movement across the stage. He also had a single gong at the end, which when the movement is timed properly should go at "dead sound on the final stroke of nine". Paul was not too sure what music to use at the end of Part One. 
Transition: The crowd decided to trudge off with some more chain-gang sounds at the end of Part One. Tom and Dan also go off though I cannot quite recall how at this stage. I would ideally like some music between the two parts and a minute's break perhaps.

\section{6) Sixth Workshop Report}

Actors Present: Tom, Dan, Hannah, Ting, Nicola

Matt offered to lead us through the workshop today. First, the group ran part one for Matt without music. Nicola took on Fiona's role in the Marie scene just for the day as we were short of actors. Matt felt that the actors had done really well with part one. He decided to look more closely at certain scenes from part one to try and make the process clearer and figure out what works and why.

\section{Unreal City}

Matt then wanted started work specifically on the Unreal City scene. He said that one of the central things that were important dramatically to this scene was rhythm, specifically the rhythm of the London crowd. Matt suggested different ways of walking. The actors caught on to one suggestion - i.e. to move their left leg forward and then drag the right one up from behind in a rhythmic fashion. The trick was to get all of them to time it perfectly together and walk one behind the other at the same time. So Matt had them walking around the space individually in this manner, in time, and then asked to get together as a line and keep walking in a circle when they felt comfortable. The actors managed to get this did in a matter of minutes. They then decided to use it for the scene. In fact, the line chose to begin the walk, which made an eerie sound as if a chain-gang was moving, even before getting onstage the next time they performed the scene.

Matt also felt that the conflict between the narrator (Tom) and Stetson (Daniel) was at the heart of the drama in the scene. The static nature of the narrator as opposed to the movement of the crowd was also seen to be dramatic. Matt's suggestion was to keep the narrator static on the chair throughout and have the line go round him once and then stop downstage in front of the audience at "with a dead 
sound on the final stroke of nine". Matt tried it out with the crowd going round the narrator a second time but instead of circling him and returning downstage, they go round him and offstage from downstage left. Tom stayed up on the chair and said all the lines to Dan (Stetson) who was constantly moving as part of the line round and behind the narrator who was on the chair between upstage left and centre. Ultimately, Stetson crossed the narrator and walks out even before the latter could say "mon semblable, mon frère". The narrator was left alone on stage at the end of the scene. Matt gave the last line to the narrator as well as he believed that it should be said by him.

\section{Madame Sosostris}

Matt revisited the Sosostris scene. Discussing it with Dan, Hannah and the rest of the team, we thought that what worked in the scene was the comedy with Hannah drawing the cards that Dan had to act out. Hannah's dramatic entry and Dan's searching for her entry point through the curtains were also noted as being good for the scene as were Dan's physicality.

Matt also pointed to the potential for the actors to interact with the audience (who were basically Sosostris' clients). Matt asked Dan and Hannah to do the scene again while thinking about the possibilities for audience interaction. Dan was already previously walking into the audience and giving a card to an audience member (Sugu who formed part of the audience for rehearsals in her role as stage manager). Now, Dan and Hannah had Nicola, Ting, Matt, Sugu and I for an 'audience'. Dan became even livelier than before and increased his level of interaction with the audience. He gave out different cards to different people and still managed to enact the cards that Sosostris picked. He even gestured to one audience member (Nicola) suggesting that she was "the lady of the rocks, the lady of situations". At the end of this performance, Dan even pulled Nicola, Ting and myself up from the 'audience' to form a crowd of people walking round in a ring, which I thought was great fun but perhaps a bit over-the-top. Matt suggested that Hannah should continue to the last line of the scene: "One must be so careful these days". While I liked what Dan was doing action-wise for the rest of the cards, I told him to try avoiding playing the hanged man as it was a card that Sosostris did not find. Instead, I asked him to show relief at not having to play it. I also thought that the element of fear in "death by water" was being lost. While the comedy was coming through, the serious moment 
was being forgotten. After this suggestion, Sosostris played the line seriously to the audience. The effect that this moment created in an otherwise comic scene was interesting. It was also suggested that Sosostris say the line: "I see crowds of people walking round in a ring" and look out at the audience who then become the crowds (audience inclusion).

\section{The Epigraph}

Matt went back to work on the epigraph. He felt here that the Sibyl's cage needed to be better structured and perhaps required two people, not one. He suggested that Ting kneel on the floor to the right of the Sibyl and enclose her with extended arms while another actor stood behind the Sibyl and enclosed her from behind. Dan suggested that instead of having an actor stand behind the Sibyl we should have one actor on either side of the Sibyl, kneeling down and enclosing her with their arms to form the cage. Ting and Dan tried this out for the beginning of Part One. Matt also asked whether the actors wanted to 'die' slower in this scene, but the actors seemed happy with a quicker pace.

\section{April is the Cruellest Month}

With the opening of the actual poem, Matt felt the rhythm of the lines were allimportant. Matt and I read the lines for the actors with Matt doing all of the first seven lines, while I joined up with him with the last word of each line and for the entire last line. Hannah then tried this line division out as the Sibyl. All the lines were given to her, but Ting, who was one part of her cage joined her on "breeding" in the first line, Dan (the other part of the cage for now) joined Hannah on "mixing", while both Dan and Ting combined to speak with Hannah for the word "stirring". Then each of the actors playing corpses was assigned words which he or she would join Hannah for and rise on at the same time. Thus I said and rose on the word 'warm' (I was filling in for Kristina) and Nicola rose on the word 'covering'. We did not return to the Countess Marie and the Desert/Tristan/Hyacinth girl scenes as some of the actors for these scenes were not present. We called it a night. 


\section{7) Seventh Workshop Report}

Actors present: Dan, Tom, William, Ting, Hannah and Fiona

Objectives: To work on and come up with dramatic scenarios for as much of Part Two as possible.

\section{Pub Scene, Part II}

I split the actors into two groups: Group A (comprising Hannah, Ting and William) and Group B (Dan, Tom and Fiona). I gave them 20 minutes each to work on the pub scene. Group B performed first: Fiona did most of the lines while Dan interjected with "she's had five already and nearly died of young George". Tom was the bartender arranging glasses and shouting out: "Hurry up please it's time". Dan and Fiona sat down in chairs at right angles with Fiona on the outside. The chairs were placed near downstage right. Tom was upstage centre and Dan, who was often bored with Fiona's monologue (he showed this boredom by letting off little gasps of air in between or 'hmmming' along), sometimes gestured to Tom to buy him a drink. At the end of what were largely Fiona's lines, Dan (who pretended to be tipsy) and Fiona walked out from downstage right saying jointly "Goodnight Bill, Goodnight Lou ta ta goodnight". Tom, who was left alone on stage then said (seemingly to the audience): "Goodnight ladies, goodnight sweet ladies" etc.

The second group (Group A) decided that the two cockney women who were talking were not going to be customers having a drink at the pub, but were workers or barmaids there. Hannah and Ting moved around the stage area from downstage right to downstage left and even other areas clearing glasses, wiping tables etc. while doing the lines. Hannah was the main speaker while Ting took the line in parenthesis. William stood upstage and almost shouted out the line "Hurry up please it's time". At the end of her line to Ting: "they asked me in to dinner to get the beauty of it hot", Hannah and Ting walked up to William and suggested that they were done for the day by saying "Goodnight Bill...tat a ... goodnight". They then left, leaving Will to say "Goodnight ladies" etc.

The team decided to put it together and have all actors in the scene. Hannah and Fiona became bargirls who were gossiping and clearing tables simultaneously. Tom sat on a high stool in the centre drinking away, cutting a lonely figure in profile. Ting and Dan sat as a couple on chairs at downstage left and William was upstage 
behind an imaginary bar. They recreated a pub setting with these several different figures and Paul introduced some jazz music "Tea for Two" which helped Hannah and Fiona time their movement and dialogue better. Hannah and Fiona gossiped downstage for a while before moving to clear Dan and Ting's table. Tom made a pass at Ting causing her to get up and exit. At the end Tom and Dan stumble out together drunk, and the two barmaids leave William alone on stage to say 'Goodnight ladies'. While I liked the creation of the setting, I felt some of the comedy of the lines was being lost by excessive movement and that the conflict between the bartender and the Cockney women was not coming through.

\section{Opening of Part Two:}

We split into two groups again for the opening section of Part Two. Initially, I gave the groups only the narrative lines from "The Chair she sat in" to "then would be savagely still'". However, as one group in particular was having real problems with dramatising these lines, I also gave both groups the section starting "My nerves are bad tonight" and going up to "pressing lidless eyes and waiting for a knock upon the door".

The first group comprised Hannah, Tom and Ting. Ting took on the role of a woman sitting at midcentre on a chair, while Hannah plays an assistant to her, helping her with her makeup. Tom just stood and read the lines at the side while this was going on. The group could not find much of dramatic value in the lines.

However, when it came to direct speech things began to move. Hannah, the assistant, disappeared for this scene, leaving Tom and Ting alone on stage. Tom was standing downstage left and staring out into the top left hand corner above the audience. Ting started "my nerves are bad tonight" sitting down centrestage. However, she got up at "stay with me" and confronted Tom with "why do you never speak?" Tom replied with a dead voice: "I think we are in rat's alley..." Ting put the rest of the questions to Tom while she moved round him in a semicircle and she threatened to "walk the street". Tom's response was again dead as he said "The hot water at ten and if it rains $[\ldots] "$

The second group (William, Dan and Fiona) decided to sit down together in a group of three and pretend to be warming their hands round a fire. They split the lines between them. This image was especially good because of the fireplace imagery that comes up later. Fiona was in the centre with the two men sitting on either side 
of her. Slowly William and Dan became more menacing as they first became the Cupidons surrounding the lady (Fiona) and later turned into leaning forms. William also made a rather obscene, in your face, gesture for "so rudely forced". Before Fiona began with "My nerves are bad tonight", Will and Dan exited and re-entered together to form a kind of mini-Chorus of two men. They sang their responses to Fiona's questions. While the men remained upstage, Fiona became the "neurotic" asking questions downstage. A moment of great hilarity ensued when Dan and Will broke into a jig and into total song and dance for "that Shakespeharian Rag". This constant singing of the lines in response to Fiona's questions continued till "We shall play a game of chess $[\ldots] "$

\section{Sibyl Scene}

Thereafter we did the Sibyl scene with music provided by Paul. I thought this music fitted better than the one used last time. We used two actors (Ting and William) for the cage on either side as suggested by Matt.

\section{Unreal City}

The crowd circled round the narrator (Tom) and then stopped downstage at nine. They then started marching and went past Tom again before exiting downstage left while Tom accused Stetson with "You hypocrite lecteur $[\ldots]$ "

\section{$\underline{\text { Discussions }}$}

We stopped to discuss scenes after we performed them. The actors felt that most of the lines of the pub scene were spoken by one Cockney woman. They did not really say what they found dramatic about it, but thought the setting was important. With the opening scene of part two, one group felt that it was difficult to dramatize as it was mainly narrative. The other group said they had no such problems but we did not really find out why this was so. The first group felt it was easier to work with this scene when the direct speech began with "My nerves are bad tonight". We called it a night as it was 9 pm by now. 


\section{8) Eighth workshop report}

Actors present: Hannah, Kristina, Ting, Tom, Dan, Nicola, William

Objectives: To set part two if possible and work on some scenes in part one

\section{Description:}

Hannah and I had also realized on Thursday that we needed to prepare the poster for the play and needed to take photographs for these on Friday. The cast came together at $6.30 \mathrm{pm}$ and Hannah took some still photographs from scenes from Part One. We then did one run of Part One in order to take photographs and also for practice. William sang the lines from Tristan und Isolde today. We also spent a lot of time working on the exact place from where the line would start entering and where it would walk in order to time the last scene of Part One ("Unreal City") properly. The line initially entered from downstage left as before and walked till downstage right before turning inward and walking to upstage right. They then turned right again to walk towards upstage left and past Tom who was on his chair giving us the lines starting "Unreal City". The line of actors did a round past Tom and went back to upstage but it did not seem to work timing-wise. Hannah then suggested that instead of crossing all the way to downstage right when they first entered, the line should first cut from upstage centre and walk a diagonal to upstage right in order to save time. However, this too did not work timing-wise i.e. the line was not ready to form up downstage again when Tom said "with a dead sound on the final stroke of nine".

Dan suggested that the actors come in from upstage right and avoid walking downstage at the start. This worked much better as it meant that the line did not have to waste time walking downstage at first. The timing was perfect and by the time Tom said "with a dead sound" they were all downstage and frozen in front of the audience. Tom also decided that he preferred coming down from the chair on the word "Stetson". He seems to say the word twice when it is only mentioned once in the poem. I think this helped him to settle down after getting down from the box. So Tom stuck to coming down on Stetson and pushing Stetson (Dan) forward and out of the line. While Tom circled Dan alright, there was a problem with Nicola (a worker in the line) being in Tom's way because Tom had not pushed Dan far enough away from the line. I suggested that the line can be a little further in rather than being so far downstage, so that Tom had space to push Dan a bit further and could circle him 
better. Dan decided that he would put Tom back into the line with him and drag him along with the other workers offstage at the end of Part One.

We now ran part one more time so that our lighting designer Ralph Upton could watch. After this run, we decided to work on the opening section of Part Two from "The Chair she sat in" to "Pressing lidless eyes and waiting for a knock upon the door". I told the cast that I thought that what the group with Fiona, William and Dan did on Tuesday with the lines from "The Chair she sat in" to "savagely still" was quite intriguing. The group then decided to do these lines with Kristina replacing Fiona as Fiona was away at work. They sat on the floor and shared the lines between William and Dan this time. Kristina did not say any lines but the two men began to menace her and start to 'enact' the rape scene in a way by surrounding Kristina and causing her to creep backwards in fear. I also told them that I thought the confrontation between the woman and her male lover / husband was good in the lines soon after. So the cast decided to use Tom as husband and bring him into one corner. Tom thought he should be disassociated from the woman (Kristina). However, he was moving about quite a bit. I thought it better if Tom stood still in one place. Tom also decided to play one of the lines angrily: "I think we are in rat's alley". However, I did not think anger worked there as the woman's whole idea was to get him stirred up, and if he does get stirred up it would be a success for her. The biggest problem though was what to do with Dan and William who earlier were menacing the woman and had been a kind of chorus / narrator but had exited the stage on "savagely still", before the woman starts speaking.

During the previous workshop William and Dan had sung the lines not said by the woman once the dialogue began. I told them that I thought the constant singing of all the lines was not essential but that it would perhaps be good to try it for some lines; for example for "Those are pearls that were his eyes" or "That Shakespeharian Rag". I said I loved what Dan and William had achieved with the dancing and singing of the 'Shakespeharian Rag' and that perhaps that should stay in some way. We first tried it with Dan and William coming in from upstage left while Tom came in from downstage left. Dan and William only joined in singing the couple of lines "Those are pearls" and "Shakespeharian Rag" from upstage, while Tom and Kristina played out their exchange of dialogue downstage. I was not too sure this worked as Dan and William looked a bit too far out of the action. 
I asked Dan and William to try coming back on stage along with Tom when he entered, being on either side of him, and perhaps joining Tom on the line "Those are pearls that were his eyes" and definitely with "Shakespeharian Rag". They did this and they danced with Tom for the Shakespeharian Rag bit. However, others in the group felt it did not work as Dan and William were frozen for too long on either side of Tom, while the woman questioned him. I thought we could get them to unfreeze at different times or pose differently but the group did not want to try this.

Nicola felt that it may be better to keep Dan and William offstage and get them to do voices or sounds from offstage when the husband is speaking / thinking. Dan and William tried doing some sounds from offstage but that did not seem to work either. Then it was decided that we try bringing Dan and William back only for the Shakespeharian Rag for a fleeting moment on stage. So it was only Tom and Kristina onstage for the exchange starting "My nerves are bad tonight". Dan and William suddenly rushed onto the stage from opposite sides - Dan from upstage right and William from upstage left on "But O O O O that Shakespeharian Rag", did a little jig together and exited separately again, all in the blink of an eye! However, some of the cast did not think this worked either. Hannah suggested playing out an entire scene of soldiers dying between "then would be savagely still" and "my nerves are bad tonight" in order to provide an understanding of "rat's alley". The rest of the actors did not seem to want to try out this idea either. I thought that it would be reading too much into the poem and that it did not necessarily stem from the lines or add to the drama in any way that would justify its presence.

I decided to leave the scene where it was and try fixing it at a later stage when the actors were happy. We moved now to the pub scene which I felt worked well on Tuesday. I did however mention that perhaps it was best that we consider the Cockney women as customers rather than waitresses since the waitresses moving around the room did not allow the lines to come across clearly. Hannah and Kristina (who was filling in for Fiona) sat in two chairs at downstage right drinking beer and gossiping. As the group was wondering what to do with so many goodnights at the end, I decided to give one goodnight to each person: Thus Dan got "Goodnight Bill", Tom got "Goodnight Lou", Kristina said "Goodnight May" and Hannah said "ta ta goodnight” as they left. The two 'drunken men' Tom and Dan left together at downstage left and the two women, Hannah and Kristina, left later. William was left 
alone on stage to say "Goodnight ladies, goodnight sweet ladies". We then wound up for the day around 9:05 pm.

\section{9) Ninth Workshop Report}

Actors Present: All eight

Matt was also present

We went scene-by-scene through Part One in the first half of the workshop rehearsal. I asked the actors to think about how they would enter for the Sibyl scene at the start of the play. I asked Hannah to come in first and the cages to follow from either side. The high priest came in from stage left and the actors decided that two disciples each would come in from either side to form the outer circle of disciples. I also asked Hannah (the Sibyl) to keep looking ahead at the audience throughout the scene rather than look at Nicola when she asks the Sibyl "I want to die".

For the second scene from 'April is the cruellest month' we practiced splitting up the lines in different ways. Matt suggested that Hannah say the first two lines: "April is the cruellest month breeding / Lilacs out of the dead land" on her own. Ting (one of the sides of the cage, Cage 1) then joined Hannah on one word "mixing". While Hannah said the words: "Memory and desire", she was joined by both sides of her cage [William (Cage 2) and Ting] for the word "stirring". From "Winter kept us warm onwards" Matt suggested a reversal of voices. Instead of Hannah saying most of the lines now, the rest of the actors said them. Thus the break-up of lines looked something like this:

Sibyl: $\quad$ April is the cruellest month breeding

Lilacs out of the dead land,

Sibyl, Cage 1: ... mixing

Sibyl: memory and desire

Sibyl, Cage 1 and Cage 2: stirring 
Sibyl: dull roots with spring rain.

Everyone except the Sibyl: Winter kept us warm

Sibyl: .... Covering

Everyone except the Sibyl: Earth in forgetful snow...

Sibyl: Feeding

All including Sibyl: A little life with dried tubers.

With the Countess Marie scene, Matt felt it would be better for Fiona to remain where she was at the end of the previous scene, that is at downstage left while the rest of the characters hustle and bustle for the setting at the start of the scene. Thus when everyone else had reached the place they had to for the Marie scene and then frozen again, Fiona (Marie 1) started speaking and walking towards the rock. It was also felt that it was better if Fiona sat upon the rock after reaching there instead of moving about all the time. Fiona tried this out and it seemed to work better. She looked towards or made a small gesture with her hand towards the couple who she needed to animate in the scene at the appropriate time.

\section{What are the roots that clutch?}

Nicola and Tom found it really difficult to do the 'What are the roots?' sequence thereafter. There was no real contact between the actors and the scene did not seem to work. Tom tried to get into the meaning of the piece but we did not seem to be getting anywhere with reworking it. I asked Nicola if she might consider pulling Tom towards her as she used to before, but she did not seem to want to try that. Tom felt that the passage should be directed more towards the audience than having the actors throw the lines at each other. We decided to return to the scene at the next workshop. 
Madame Sosostris:

Matt suggested that Sosostris could sit on the rock in a kind of lotus pose while her assistant did all the moving around. Dan seemed to have reduced some of the interaction with the audience he had earlier for this scene. Matt reminded him that he (Dan) needed to use this more. Also, Hannah thought that Dan could say "thank you" to wake Sosostris from her 'death by water' trance.

\section{Unreal City:}

Tom decided that he would come down from his chair on Stetson as before. I asked Tom to avoid moving too much around Stetson downstage and select what exact movements he would like. Dan also decided as Stetson to put Tom back in the line in his place and then join the line at the end. Matt suggested that instead of walking to the back of the line at the end and joining there, Dan should just wait till the line walks past him and then join up in the line. Also the line now began to exit from upstage right as there were now seven actors in the line at the start, forcing Kristina the leader of the line to turn inwards and face upstage a bit at "a dead sound on the final stroke of nine". No music was used.

\section{Part Two:}

\section{The Chair she sat in:}

William, Dan and Kristina did this scene as a group of three people sitting on the floor and warming their hands around an imaginary fire. When it came to the mentioning of Philomel the men became menacing and surrounded Kristina as they did last week and she moved backwards along the floor. Dan and William left the stage after the words "savagely still". Tom then entered and took up a position at downstage left. Kristina threw the lines at Tom as they did last week. This time, however, Dan and William decided to sing the 'Shakespeherean Rag' offstage. The idea seemed to work as it did not distract from what Tom and Nicola were doing but at the same time created enough interest in the sound offstage, and its link to what was happening onstage for an 'audience' we felt. 
The Pub scene:

Hannah put in some more drunkenness into the scene. It seemed to work well. They did this much the same way as Friday except that Hannah got more drunk and there was greater interaction between Hannah and Fiona.

Matt asked the actors and me to think about the theme of death running through Part One and any common ideas in Part Two. He also asked us to look at bringing out the poetry of the lines better and the rhythm.

\section{0) Tenth Workshop report}

Actors present: all

Gregor was shooting with the camera

We first worked on the "What are the roots that clutch" scene. I asked Tom and Nicola to try something different from what they were doing earlier. Tom then decided that audience inclusion was important with this scene. Nicola and he decided to enter from upstage centre, from behind the curtain but then move to either side of the rock. Tom moved to the right of the rock and came to downstage right where he stared at the audience for some time in silence with a slightly crazed look on his face. Nicola simultaneously had come to downstage left and took up a similar position to Tom without Tom's menacing look. Tom then began to speak throwing his lines at the audience. The division took place in this manner between the actors:

Tom: What are the roots that clutch? What branches grow

Out of this stony rubbish? Son of man you cannot say or guess

For you know only a heap of broken images, where the sun beats

Nicola: and the dead tree gives no shelter, the cricket no relief

And the dry stone no sound of water. Only

There is shadow under this red rock

Tom: Come in under the shadow of this red rock (gestures towards box) 
And I will show you something different

From either your shadow at morning striding behind you

(Tom starts walking toward Nicola at this stage, taking two steps

towards her. Nicola had her back toward him)

Nicola: (turning to face Tom and moving towards him. She takes two steps towards him so they are face-to-face at the end of this line)

Or your shadow at evening rising to meet you.

Tom: (bending down in front of Nicola near downstage-centre and 'picking up' a handful of dust.)

I will show you fear in a handful of dust.

The half-kneeling Tom then shifted the imaginary dust into Nicola's right hand. He put his right hand over hers to transfer the dust. She then put out her right hand and inverted it slowly releasing the 'dust' to the ground through her thumb and forefinger. This scene seemed to work well now and when we put it together with Ting as the Hyacinth girl it gave us a workable transition as well. So we decided to stick to it.

Part Two: The Chair she sat in:

I felt that the early section of Part Two from "The Chair she sat in" (1. 77) to "a carved dolphin swam" (1.96) was not working as the three actors seemed to be just sitting down in one place pretending they were at a fire. I asked the actors to consider the possibilities of movement for the two men around the lady if we kept her on the rock and used the men as narrators.

I asked William and Dan to split the lines between them in this long descriptive passage and try doing something with the piece themselves keeping Kristina on the rock. This was what they did: Kristina came in first and sat upon the rock from upstage centre. Dan and William followed. William got into a crouching position at Kristina's right while Dan decided to come down towards the audience first and throw the opening lines at the audience after first crossing Kristina and the rock. He later went back to the rock. Dan spoke the following lines: 
Dan: The Chair she sat in, like a burnished throne,

Glowed on the marble, where the glass

Held up by standards wrought with fruited vines

From which a golden Cupidon peeped out

He began to move upstage towards Kristina after the first couple of lines and then hid his eyes when William said: "(Another hid his eyes behind his wing)”. On this line, William also got activated and broke his near-freeze next to Kristina to create a situation where he was beginning to stir around Kristina who was still staring out blankly.

William continued up to "satin cases poured in rich profusion". Dan took over from "In vials of ivory" and said the lines up to coffered ceiling, looking upward at that point. William then said the lines from "Huge sea-wood" and although I had told Dan and William to try and get Kristina off the rock for the rape scene, they were unable to do so, and the rest of the scene turned out to be little more than a reading. We now felt that the first section was working better but that we had to know what to do to get Kristina off the rock just before the mention of the rape of Philomel.

There were two suggestions from the group - one was that she be 'pushed' a bit by William on "so rudely forced" and 'fall' backward. The other suggestion was that she should fall of her own accord from the rock frightened by the words of the men and their menacing gestures. Kristina tried falling on her own on the word 'forc'd'. However, she also tried another way after I suggested that she could stand and warm her hands in front of an imaginary fireplace at "huge sea-wood fed with copper". Kristina decided to stand and move forward towards the audience between downstage right and downstage centre. Dan was to her right and William to her left. Dan made a threatening gesture with his hand at which Kristina 'fell' backwards to the floor and the two men then played out the 'rape' scene as before. This seemed to work and we decided to leave it there.

After working a bit with the Sibyl scene, we did a run of Parts One and Two with the wash and music. It took about 25 minutes in all. We returned to work a bit on Kristina's dialogue delivery starting "my nerves are bad tonight" to get as much as possible out of the scene, language-wise. Gregor had a chat with the actors where 
he suggested that the most important aspect of the scenes in the 'play' was the opposition between elements: something which we could link perhaps to the lyricdramatic interaction in the poem.

Thus we came to end of our tenth workshop which was essentially the last time we devised any matter for the scenes themselves. The last two meetings before the performance were pure rehearsals ahead of the opening night. 


\section{WORKS CITED}

Abbott, L. and Seroff, D. Ragged but Right: Black Traveling Shows, "Coon Songs," And the Dark Pathway to Blues and Jazz. Jackson: University Press of Mississippi, 2007.

Abrams, M. H. A Glossary of Literary Terms. Sixth ed. Forth Worth, Texas: Thomson Wadsworth, 1985.

---. The Correspondent Breeze: Essays on English Romanticism. New York, London: W W Norton and Company 1984.

Ackroyd, P. T. S. Eliot: A Life. New York: Simon, 1984.

Aeschylus. The Oresteian Trilogy. Harmondsworth, Middlesex: Penguin, 1956.

Aiken, C. "An Anatomy of Melancholy." Critical Essays on T. S. Eliot's The Waste Land. Ed. L. A. Cuddy \& D. H. Hirsch. Boston: G K Hall \& Co, 1991. 32-36.

Aristotle. The Poetics of Aristotle. Trans. S H Butcher. Fourth ed. London: Macmillan and Co, 1922.

Auden, W. H. "The Dance of Death." W. H. Auden and Christopher Isherwood: Plays and Other Dramatic Writings by W. H. Auden 1928-1938. London: Faber and Faber Ltd, 1989.

Avery, H. P. "The Family Reunion Reconsidered." Educational Theatre Journal 17.1 (1965): 10-18.

Baker, R. A. British Music Hall: An Illustrated History. Stroud: Sutton Publishing Limited, 2005.

Barnet S., M. Berman \& W. Burto. Aspects of the Drama: A Handbook. Boston: Little, Brown and Co., 1962

Baudelaire, C. The Flowers of Evil. Trans. J. McGowan. New York: Oxford University Press, 1993.

---. Oeuvres Completes. Paris: Gallimard, 1961.

Bauerle, R. ed. The James Joyce Songbook. New York, London: Garland Publishing Inc, 1982.

Beckerman, B. Dynamics of Drama: Theory and Method of Analysis New York: Alfred A Knopf, 1970.

Bedient, C. He Do the Police in Different Voices: 'The Waste Land' and Its Protagonist. Chicago: University of Chicago Press, 1986. 
Behr, C. T. S. Eliot: A Chronology of His Life and Works. London: Macmillan, 1983.

Bell, C. Ritual Theory, Ritual Practice. Oxford: Oxford University Press, 1992.

Bell, J. Strings, Hands, Shadows: A Modern Puppet History. Detroit, Michigan: Detroit Institute of Arts, 2000.

Bentley, E, ed. From the Modern Repertoire. Vol. 1. Denver: University of Denver Press, 1949.

Bentley, J. Hallie Flanagan: A Life in the American Theatre. New York: Alfred A. Knopf, 1988.

Bergonzi, B. T S Eliot New York, London: Macmillan, 1972.

Bornstein, G. Transformation of Romanticism in Yeats, Eliot, and Stevens. Chicago: The University of Chicago Press, 1967.

Brady, A. P. Lyricism in the Poetry of T. S. Eliot. New York: Kennikat Press, 1978.

Brantley, B. (1996). "Memory and Desire: Hearing Eliot's Passion." The New York Times, Theater Review, Nov. 18, 1996. Website accessed on March 19, 2010: http://theater2.nytimes.com/mem/theater/treview.html? $\mathrm{r}=1 \&$ html title $=\&$ tols title $=$ WASTE\%20LAND, \%20THE\%20(PLAY)\&pdate $=19961118 \&$ byline $=$ By\%2 0BEN\%20BRANTLEY\&id=1077011432872

Brecht, B. Brecht on Theatre: The Development of an Aesthetic. Trans. J. Willett. London: Methuen drama, 1990

Brockett, O. G. \& J. F. Hildy. History of the Theatre. 1968. Eighth ed. Boston: Allyn and Bacon, 1999.

Browning, R. Robert Browning: The Major Works. Oxford World's Classics. Oxford, New York: Oxford University Press, 1997.

Bush, R. T. S. Eliot: A Study in Character and Style. New York: Oxford University Press, 1983.

Butler, A. The lives of the fathers, martyrs, and other principal saints: compiled from original monuments, and other authentic records. Vol. 1, Dublin, 1779-80. Printed by J. Exshaw for J. Morris, 1779-80, 312. Accessed from Eighteenth Century Collections Online on March 19, 2010 at:

http://galenet.galegroup.com.helicon.vuw.ac.nz/servlet/ECCO?dd=0\&locID=vuw\&d $1=1236300101 \&$ srcht $\mathrm{p}=\mathrm{a} \& \mathrm{c}=1 \& \mathrm{SU}=0 \mathrm{LRF} \& \mathrm{df}=\mathrm{f} \& \mathrm{~d} 2=311 \& \mathrm{docNum}=\mathrm{CW} 3323461$ 563\&h2=1\&vrsn=1.0\&af=BN\&d6=311\&d3=311\&ste=10\&stp=Author\&d4=0.33\&n $=10 \& \mathrm{~d} 5=\mathrm{d} 6 \& \mathrm{ae}=\mathrm{N} 047526$

Byron, G. Dramatic Monologue. London: Routledge, 2003. 
Carpentier, M. C. Ritual, Myth, and the Modernist Text: The Influence of Jane Ellen Harrison on Joyce, Eliot, and Woolf. Amsterdam: Gordon and Breach, 1998.

Charvet, P. E. A Literary History of France, Volume V: The Nineteenth and Twentieth Centuries 1870-1940. London: Ernest Benn, 1993.

Chinitz, D. E. "In the Shadows: Popular Song and Eliot's Construction of Emotion." MODERNISM/modernity 11.3 (2004): 449-67.

---. "T. S. Eliot and the Cultural Divide." PMLA 110.2 (1995): 236-47.

---. T S Eliot and the Cultural Divide. Chicago and London: The University of Chicago Press, 2003.

Christ, C T. "Self-Concealment and Self-Expression in Eliot's and Pound's Dramatic Monologues." Victorian Poetry 22.2 (1984): 217-26.

Coffman Jr., S K. Imagism: A Chapter for the History of Modern Poetry. New York: Octagon Books, 1972.

Coghill, N. "Introduction and Notes." Murder in the Cathedral by T. S. Eliot. London: Faber and Faber, 1965.

Cole, B., J.W. Johnson and R. Johnson. "Under the Bamboo Tree." Favorite Songs of the Nineties. Ed. R A Fremont. New York: Dover, 1973. 330-33.

Cornford, F M. The Origin of Attic Comedy. 1914. Second ed. Cambridge: Cambridge at the University Press, 1934.

Crawford, R. The Savage and the City in the Work of T S Eliot. Oxford: Clarendon Press, 1987.

Cray, E. The Erotic Muse : American Bawdy Songs Urbana: University of Illinois Press, 1992.

Cuddon, J A. A dictionary of literary terms and literary theory. USA: Blackwell Reference, 1991.

Curry, S S. Browning and the Dramatic Monologue. New York: Haskell House, 1965.

Davidson, J. John Davidson: A Selection of His Poems. London: Hutchinson, 1961.

Deak, F. Symbolist Theater: The Formation of an Avant-Garde. Baltimore: The Johns Hopkins University Press, 1993

De la Mare, W. The Complete Poems of Walter De La Mare. London: Faber and Faber, 1969. 
Dickens, C. Our Mutual Friend. Everyman's Library. London: David Campbell Publishers, 1994.

Dobree, B. "T. S. Eliot: A Personal Reminiscence." T. S. Eliot: The Man and His Work. Ed. A. Tate. New York: Delacorte Press, 1966, 65-88.

Donoghue, D. The Third Voice: Modern British and American Verse Drama. Princteon, New Jersey: Princeton University Press, 1959.

DuPlessis, R. B. Genders, Races and Religious Cultures in Modern American Poetry, 1908-1934. Cambridge: Cambridge University Press, 2001.

Edwards, B. H. "Louis Armstrong and the Syntax of Scat." Critical Inquiry 28.3 (2002): 618-49.

Edwards, G. By the light of the silvery moon. Accessed on $18^{\text {th }}$ March, 2010 at http://library.duke.edu/digitalcollections/hasm.n0558/pg.3/

Eliot, T. S. "The Ballet. A Review of The Dance: An Historical Survey of Dancing in Europe, by Cecil J. Sharpe, and A.P. Oppe, and Mudras: The Ritual Hand Poses of the Buddha Priests and Shiva Priests, by Tyra De Kleen." Criterion 3.2 (Apr. 1925): 441-43.

---. "The Beating of a Drum. A Review of Studies in the Development of the Fool in the Elizabethan Drama, by Olive Mary Busby." Nation \& Athenaeum 34.1 (Oct. 1923): 11-12.

---. The Complete Poems and Plays of T.S. Eliot. London: Faber and Faber, 1969.

---. "Dramatis Personae." Criterion 1.3 (Apr. 1923): 303-06.

---. "The Duchess of Malfi at the Lyric and Poetic Drama " Art and Letters 3.1 (1920): 36-39.

---. "'Durkheim', a Review of The Elementary Forms of the Religious Life. A Study in Religious Sociology by Emile Durkheim. Trans. By J. W. Swain." The Saturday Westminster Gazette (Aug. 1916): 24.

---. For Lancelot Andrewes: Essays on Style and Order. Garden City, New York: Doubleday, Doran, 1928.

---. Introduction. Savonarola: A Dramatic Poem. By Charlotte Eliot. London: R. Cobden-Sanderson, 1926. vii-xii.

---. Introduction. Shakespeare and the Popular Dramatic Tradition by S. L. Bethell. Westminster: P.S. King and Staples, 1944.

---. Inventions of the March Hare: Poems 1909-1917. London: Faber and Faber, 1996.

---. "John Dryden." Times Literary Supplement 1012 (Jun. 1921): 361-62. 
---. The Letters of T.S. Eliot: Volume 1, 1898-1922. Ed. V. Eliot and H. Haughton. London: Faber and Faber, 2009. Vol. 1.

---. The Letters of T.S. Eliot: Volume 2, 1923-1925." Ed. V. Eliot and H. Haughton. London: Faber and Faber, 2009. Vol. 2.

---. "London Letter." Dial 70.6 (Jun. 1921): 686-91.

---. "London Letter." Dial 71.2 (Aug. 1921): 213-17.

---. "London Letter." Dial 71.4 (Oct. 1921): 452-55.

---. "The Man Who Was King." Smith Academy Record Jun. 1905: 1-3.

---. "Marianne Moore. A Review of Poems and Marriage, by Marianne Moore." Dial 75.6 (Dec. 1923): 594-97.

---. "Metaphysical Poets." Times Literary Supplement 1031 (Oct. 20, 1921): 669-70.

---. On Poetry and Poets. London: Faber and Faber, 1957.

---. "The Poetic Drama." Athenaeum 4698 (May 1920): 635-36.

---. Preface. John Davidson: A Selection of His Poems. Ed. Maurice Lindsay. London: Hutchinson, 1961.

---. The Rock. London: Faber and Faber, 1934.

---. "Rev. of The Growth of Civilisation and The Origin of Magic and Religion by W. J. Perry." Criterion 2.8 (Jul. 1924): 489-91.

---. The Sacred Wood: Essays on Poetry and Criticism. 1920. Seventh ed. New York: Metheun \& Co, 1950.

---. Selected Essays. 1933. Second ed. London: Faber and Faber, 1934.

---. "A Tale of a Whale." Smith Academy Record Apr. 1905: 1-3.

---. To Criticize the Critic and Other Writings. New York: Farrar, 1965.

---. "War-Paint and Feathers. Rev. of The Path of the Rainbow: An Anthology of Songs and Chants from the Indians of North America." Athenaeum (Oct. 1919): 1036.

---. "The Waste Land: A Facsimile and Transcript of the Original Drafts Including the Annotations of Ezra Pound." Ed. Valerie Eliot. London: Faber and Faber, 1971.

Esslin, M. "Modern Theatre: 1890-1920." The Oxford Illustrated History of Theatre. Ed. J. Russell Brown. Oxford: Oxford University Press, 1995. 341-79. 
Ewen, D. The Life and Death of Tin Pan Alley. New York: Funk, 1964.

Ferrall, C. Modernist Writing and Reactionary Politics. Cambridge: Cambridge University Press, 2001.

Flanagan, H. Dynamo. New York: Duell, Sloan and Pearce, 1943.

Floyd Jr., S. A. "African Roots of Jazz." The Oxford Companion to Jazz. Ed. Bill Kirchner. New York: Oxford University Press, 2000. 7-16.

Frazer, J G. The Golden Bough: A Study in Magic and Religion. Abridged ed. London: Macmillan, 1922.

Freedman, M. "Jazz Rhythm and T.S. Eliot." The South Atlantic Quarterly 51 (1952): 419-35.

Galef, D. "Fragments of a Journey: The Drama in T. S. Eliot's Sweeney Agonistes." English Studies 69 (1988): 497-508.

Gardner, H. The Art of T.S. Eliot. London: Faber and Faber, 1968.

---. The Composition of Four Quartets. London: Faber and Faber, 1978.

Geary, E. A. "T. S. Eliot and the Fin De Siècle." Rocky Mountain Review of Language and Literature 40.1/2 (1986): 21-33.

Giannone, R. J. "Eliot's 'Portrait of a Lady' and Pound's 'Portrait D'une Femme'." Twentieth Century Literature 5.3 (1959): 131-34.

Gilbert, W. S. The Complete Gilbert and Sullivan. London: Penguin Books, 2006.

Goodridge, J. Rhythm and Timing of Movement in Performance: Drama, Dance and Ceremony. London: Jessica Kingsley Publishers, 1999.

Gordon, L. T.S. Eliot: An Imperfect Life. New York: W.W. Norton, 1998.

Grant, M., ed. T. S. Eliot: The Critical Heritage. Vol. 1, 2. London: Routledge \& Kegan Paul, 1982.

Grove, R. "Pereira and After: The Cures of Eliot's Theater." The Cambridge Companion to T.S. Eliot. Ed. A. David Moody. Cambridge: Cambridge University Press, 1994. 158-175.

Hargrove, N. D. "T. S. Eliot and the Dance." Journal of Modern Literature 21.1 (1997): 61-88.

---. "T. S. Eliot and the Parisian Theatre World, 1910-1911." South Atlantic Review 66.4 (2001): 1-44. 
Harrison, J. E. Ancient Art and Ritual. London: Williams and Norgate, 1913.

---. Themis: A Study of the Social Origins of Greek Religion. 1912. London: Merlin Press, 1963.

---. Reminiscences of a Student's Life. London: Hogarth Press, 1925.

Hartnoll, P. The Oxford Companion to the Theatre. Fourth ed. Oxford: Oxford University Press, 1983.

Harvey, P., comp. The Oxford Companion to Classical Literature. Oxford: Oxford University Press, 1937.

Hasenclever, W. "The Task of Drama." Twentieth-Century Theatre: A Sourcebook. Ed. R Drain. London: Routledge, 1995. 31-32.

Hatch, J. V. "American Minstrelsy in Black and White." A History of African American Theatre. Ed. E. G. Hill and J. V. Hatch. Cambridge: Cambridge University Press, 2003.

Hodgson, T. The Batsford Dictionary of Drama. London: B. T. Batsford, 1988.

Howarth, H. Notes on Some Figures Behind T. S. Eliot. London: Chatto \& Windus, 1965.

Howe, E. A. The Dramatic Monologue. New York: Twayne, 1996.

Hulme, T. E. Speculations: Essays on Humanism and the Philosophy of Art. London: Routledge \& Kegan Paul Ltd, 1936.

Jain, M. T. S. Eliot: Selected Poems. Delhi: Oxford University Press, 1992.

Jayne, S. "Mr Eliot's Agon." Critical Essays on T.S. Eliot: The Sweeney Motif. Ed. Kinley E. Roby. Boston, Massachusetts: G. K. Hall \& Co, 1985.

Jones, D. E. The Plays of T. S. Eliot. London: Routledge \& Kegan Paul, 1960.

Kelly, K. E. "An Unnatural Eloquence: Eliot's Plays in the Course on Modern Drama." Approaches to Teaching Eliot's Poetry and Plays. Ed. J. S. Brooker. New York: The Modern Language Association of America, 1988. 169-73.

Kenner, H. The Invisible Poet: T. S. Eliot. London: W. H. Allen, 1960.

Kermode, F. "Introduction." The Waste Land and Other Poems. London: Penguin Classics, 1998.

Kift, D. The Victorian Music Hall : Culture, Class, and Conflict Trans. Roy Kift. Cambridge: Cambridge University Press, 1996. 
Knowles, S. D. G. "'Then You Wink the Other Eye': T. S. Eliot and the Music Hall' " $\underline{A N Q} 11.4$ (Fall 1998).

Laforgue, J. "Another Complaint of Lord Pierrot", Flores, A., ed. An Anthology of French Poetry from Nerval to Valery in English Translation with French Originals. Trans. J. Bennett. New York: Doubleday, 1958. 208-209.

---. "Autre Complainte de Lord Pierrot." Flores, A., ed. An Anthology of French Poetry from Nerval to Valery in English Translation with French Originals. New York: Doubleday, 1958, 391.

---. "Locutions des Pierrots." Rees, W, ed. French Poetry 1820-1950. London: Penguin Books, 1990, 341-344.

---. Selected Writings of Jules Laforgue. Trans. W. J. Smith. Westport, Connecticut: Greenwood Press, 1956.

Langbaum, R. The Poetry of Experience: The Dramatic Monologue in Modern Literary Tradition. London: Chatto \& Windus, 1957.

Lawrence, D H. "Introduction to His Paintings." Selected Essays. Harmondsworth, Middlesex: Penguin Books, 1950. 307-346.

Lewis, W. "Manifesto." Blast 1 (1914): 30, 33.

Lightfoot, M. J. "Charting Eliot's Course in Drama." Educational Theatre Journal 22 (1968): 186-97.

Lindley, D. Lyric. London; New York : Methuen, 1985.

Lindsay, V. Selected Poems of Vachel Lindsay. New York: Macmillan, 1963.

Lloyd Webber, A. Cats, http://www.andrewlloydwebber.com/shows/cats/ Accessed on March 19, 2010.

Logenbach, J. "Ara Vos Prec: Eliot's Negotiation of Satire and Suffering." ․ S. Eliot: The Modernist in History. Ed. R. Bush. Cambridge: Cambridge University Press, 1991. 41-66.

Mack, R L. The Wonderful and Surprising History of Sweeney Todd: The Life and Times of an Urban Legend. New York: Continuum, 2007.

Maeterlinck, M. The Double Garden. Trans. Alexander Teixeira de Mattos. London: George Allen, 1904.

Malamud, R. T. S. Eliot's Drama: A Research and Production Sourcebook. Westport, Connecticut: Greenwood Press, 1992.

Manganaro, M. Myth, Rhetoric, and the Voice of Authority: A Critique of Frazer, Eliot, Frye, and Campbell. New Haven: Yale University Press, 1992. 
Martin Browne, E. "From The Rock to The Confidential Clerk " T.S. Eliot: A Symposium for His Seventieth Birthday. Ed. Neville Braybrooke. Port Talbot, Glamorgan: Garnstone Press, 1958. 57-69.

---. The Making of T. S. Eliot's Plays. Cambridge: Cambridge at the University Press, 1969.

Matthiessen, F O. The Achievement of T. S. Eliot: An Essay on the Nature of Poetry. 1935. Third ed. New York: Oxford University Press, 1958.

Mayer, J T. T. S. Eliot's Silent Voices. New York: Oxford University Press, 1989.

McCue, J. "Editing Eliot." Essays in Criticism 56.1 (2006): 1-27.

McNeilly, Kevin. "Culture, Race, Rhythm - 'Sweeney Agonistes' and the Live Jazz Break." T. S. Eliot's Orchestra: Critical Essays on Poetry and Music. Ed. John Xiros Cooper. New York: Garland Pub. , 2000. 25-48.

Meet Me in St. Louis. 1944. A. Freed.

Miller, J. E. Jr. T. S. Eliot: The Making of an American Poet, 1888-1922. University Park, Pennsylvania: Pennsylvania State University Press, 2005.

Moody, A. D. Thomas Stearns Eliot, Poet. Cambridge Cambridge University Press, 1979.

Morath, M. "Ragtime Then and Now." The Oxford Companion to Jazz. Ed. Bill Kirchner. New York: Oxford University Press, 2000. 29-38.

Moulton, R. G. The Ancient Classical Drama: A Study in Literary Evolution. 1890. Second ed. Oxford: Clarendon Press, 1898.

Murphy, M. S. A Tradition of Subversion: The Prose Poem in English from Wilde to Ashbery. Amherst: University of Massachussets Press, 1992.

New Catholic Encyclopaedia. Second ed. Detroit: Thomson/Gale, 2003.

The New Encyclopaedia Britannica Fifteenth ed. Chicago: Encyclopaedia Britannica, 1988.

The New Grove Dictionary of Jazz. Ed. K. Barry. Second ed. New York: Grove, 2002.

The New Princeton Encyclopedia of Poetry and Poetics. Princeton: Princeton University Press, 1993.

The New Shorter Oxford English Dictionary on Historical Principles. Ed. L. Brown. Oxford: Clarendon Press. 2 vols, 1993. 
Nietzsche, F. The Birth of Tragedy and Other Writings. Trans. R Speirs. Cambridge Cambridge University Press, 1999.

North, M. The Dialect of Modernism: Race, Language, and Twentieth Century Literature. New York: Oxford University Press, 1994.

OED Online. Second edition 1989._Oxford University Press. http://www.oed.com/

The Oxford English Dictionary. New York: Oxford University Press, 1989.

Parker, L. N. Several of My Lives. London: Chapman and Hall 1928.

Parsonage, C. The Evolution of Jazz in Britain, 1880-1935. Aldershot, Hampshire: Ashgate Publishing Limited, 2005.

Peter, J. "Murder in the Cathedral." The Sewanee Review 61.3 (1953): 362-83.

Petronius. The Satiricon. New York: Appleton-Century-Crofts, 1969.

Petronius. Petronius 'the Satyricon', Seneca 'the Apolcolocyntosis'. Trans. J. P. Sullivan. London: Penguin Books, 1986.

Pfister, M. The Theory and Analysis of Drama. Das Drama (1977), Munich: Wilhelm Fink Verlag. Trans. John Halliday. Cambridge Cambridge University Press, 1988.

Pickering, M. "White Skin, Black Masks: 'Nigger' Minstrelsy in Victorian Britain." Music Hall: Peformance and Style. Ed. J. S. Bratton. Milton Keynes: Open University Press, 1986.

Pierrot, J. The Decadent Imagination 1880-1900. Trans. D. Coltman. Chicago: University of Chicago Press, 1981.

Pitt, G D. "The String of Pearls." The Golden Age of Melodrama : Twelve 19th Century Melodramas Ed. M Kilgarriff. London: Wolfe, 1974.

Potter, R. The English Morality Play: Origins, History and Influence of a Dramatic Tradition. London: Routledge \& Kegan Paul, 1975.

Pound, E. "The New Sculpture." Egoist 1 (1914): 68.

Raine, C. T. S. Eliot. Oxford: Oxford University Press, 2006.

Raffel, B. T. S. Eliot. New York: Ungar, 1982.

Rees, T. R. The Technique of T. S. Eliot; a Study of the Orchestration of Meaning in Eliot's Poetry. The Hague: Mouton, 1974.

Rhodes, C. Primitivism and Modern Art. London: Thames and Hudson, 1994. 
Richards, J. Imperialism and Music: Britain 1876-1953. Manchester: Manchester University Press, 2001.

Robinson, A. The Life and Work of Jane Ellen Harrison. Oxford Oxford University Press, 2002.

Sanders, C. "The Waste Land: The Last Minstrel Show?" Journal of Modern Literature 8.1 (1980): 23-38.

Schelling, F. E. The English Chronicle Play: A Study in the Popular Historical Literature Environing Shakespeare. New York Haskell, 1964.

Schuchard, R. Eliot's Dark Angel: Intersections of Life and Art. New York, Oxford: Oxford University Press, 1999.

Scofield, M. T. S. Eliot: The Poems. Cambridge: Cambridge University Press, 1988.

Seed, D. "Monologue and Dialogue in The Waste Land." Critical Essays on 'The Waste Land', T. S. Eliot. Ed. B Loughrey L Cookson. Harlow: Longman, 1988.

Seferis, G. "Introduction to T. S. Eliot." MODERNISM/modernity 16.1 (2009): 146170.

Sessions, I. B. "The Dramatic Monologue " PMLA 62.2 (1947): 503-16.

Seymour-Jones, C. Painted Shadow: The Life of Vivienne Eliot. New York: Doubleday, 2002.

Shakespeare, W. Hamlet. London: Arden Shakespeare, 2006.

Shakespeare, W. Othello. Cambridge: Cambridge University Press, 2003.

Shelley, P. B. Percy Bysshe Shelley: The Major Works. New York: Oxford University Press, 2003.

Shipton, A. A New History of Jazz. London and New York: Continuum, 2001.

Sidnell, M. J. Dances of Death: The Group Theatre of London in the Thirties. London: Faber 1984.

Sigg, E. The American T. S. Eliot: A Study of the Early Writing. Cambridge: Cambridge University Press, 1989.

Sinfield, A. Dramatic Monologue. London: Methuen \& Co. Ltd. , 1977.

Skaff, W. The Philosophy of T. S. Eliot : From Skepticism to a Surrealist Poetic, 1909-1927. Philadelphia : University of Pennsylvania Press,, 1986. 
Smidt, K. Poetry and Belief in the Work of T. S. Eliot. London: Routledge \& Kegan Paul, 1961.

Smith, C. H. T. S. Eliot's Dramatic Theory and Practice: From 'Sweeney Agonistes' to 'The Elder Statesman'. Princeton, New Jersey: Princeton University Press, 1963.

Smith, G. T. S. Eliot's Poetry and Plays: A Study in Sources and Meaning. 1956. Second ed. Chicago, London: University of Chicago Press, 1974.

Soldo, J. J. The Tempering of T. S. Eliot. Ann Arbor, Mi.: Umi Research Press, 1983.

Solomis, A. The Living Aristophanes. Trans. Alexis Solomos and Marvin Felheim. Ann Arbor: The University of Michigan Press, 1974.

Southam, B. C. A Student's Guide to the Selected Poems of T. S. Eliot. 1968. Fifth ed. London: Faber and Faber 1990.

Starkie, E. From Gautier to Eliot: The Influence of France on English Literature 1851-1939. London: Hutchinson, 1960.

Stead, C. K. The New Poetic: Yeats to Eliot. London: Continuum, 2005.

Stillman, A. "Sweeney among the Marionettes " Essays in Criticism 59.2 (2009): 116-141.

Svarny, E. M. The Men of 1914: T. S. Eliot and Early Modernism. Milton Keynes: Open University Press, 1988.

Toll, R. C. Blacking Up: The Minstrel Show in Nineteenth-Century America. New York: Oxford University Press, 1974.

Tottel, R. Richard Tottel's Songes and Sonettes: The Elizabethan Version. Ed. Paul A Marquis. Tempe, Arizona: Arizona Center for Medieval and Renaissance Studies, 2007.

Tzara, T. Oeuvres Completes, Tome 1, 1912-1924. Vol. 1. Paris: Flammarion, 1975.

Vickery, J. B. The Literary Impact of 'The Golden Bough. Princeton University Press, 1973

Wagner, R. Tristan and Isolde. Trans. Stewart Robb. New York: E. P. Dutton, 1965.

---. Götterdämmerung. Trans. Rudolph Sabor. London: Phaidon Press, 1997.

Ward, D. T. S. Eliot between Two Worlds. Boston: Routledge \& Kegan Paul, 1973.

Wilson, E. Axel's Castle: A Study in the Imaginative Literature of 1870-1930. New York: Charles Scribner's Sons, 1931. 
Wittke, C. F. Tambo and Bones: A History of the American Minstrel Stage. Durham, N. Carolina: Duke University Press, 1930.

Wolf, W. "The Lyric: Problems of Definition and a Proposal for

Reconceptualisation." Theory into Poetry: New Approaches to the Lyric. Ed. E. Muller-Zettelmann and M. Rubik. Amsterdam: Rodopi, 2005.

Woll, A. Black Musical Theatre: From "Coontown" To "Dreamgirls". Baton Rouge, La.: Louisiana State University Press, 1989.

Womar, C. The Subterranean Railway. London: Atlantic Books, 2004.

Woolf, V. "The Diary of Virginia Woolf." Ed. Anne Olivier Bell. London: Hogarth Press, 1977-1984. Vol. 2. 5 vols.

Wordsworth, W. "Tintern Abbey" Romantic and Victorian Poetry. Ed. William Frost. Englewood Cliffs, N. J.: Prentice-Hall Inc., 1961.

Worth, K. "Eliot and the Living Theatre." Eliot in Perspective: A Symposium. Ed. G. Martin. London: Macmillan \& Co, 1970.

Wundt, W. Elements of Folk Psychology. Outlines of a Psychological History of the Development of Mankind. Trans. E. Leroy Schaub. London: George Allen \& Unwin, 1916.

Yeats, W. B. The Collected Works of W. B. Yeats, Vol. II: The Plays. New York: Scribner, 2001.

Youngren, W. H. "European Roots of Jazz." The Oxford Companion to Jazz. Ed. Bill Kirchner. New York: Oxford University Press, 2000. 17-28. 
